
<smiles>CCCCCCC</smiles> 






PORTRAITS AND HABITS OF OUR BIRDS 



\title{
Portraits and Habits of Our Birds
}

Prepared by Various Authors

\author{
Edited by \\ T. Gilbert Pearson
}

Illustrated with Fifty Colored Plates by Louis Agassiz Fuertes, R. Bruce Horsfall, Edmund J. Sawyer, Allan Brooks, and R. I. Brasher; also Thirty-one Photographs and Drawings from Nature

Volume II

National Association of Audubon Societies

New York City

I 92 I 
COPYRIGHT BY
NATIONAL ASSOCIATION OF AUDUBON SOCIETIES 


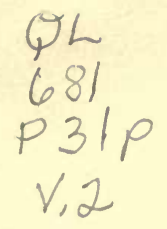

\section{FOREWORD}

IT is a fact well known to field naturalists that in the heavily forested lands of North America comparatively few birds are to be seen. The conditions of life are such that ordinarily far more are found where a portion of the land is under cultivation. The diversified crops, weeds, plants, fruit-bearing shrubs and trees, with their attendant hoards of insects found in and about cultivated regions all tend to make more favorable living conditions for wild birds. In sections, therefore, where open fields are interspersed with thickets, grown-up fence rows, orchards and small areas of woodlands, and the country traversed with streams, one will generally find bird life more abundant. Then, too, in the settlements men have destroyed many of the smaller animals and snakes that prey upon birds. Any species of wild life provided with abundant food and insured against an excessive loss from the depredations of its enemies will increase in numbers.

Undoubtedly the farm-land birds of North America have greatly increased since the discovery and settlement of the continent. Only those that could be, and have been, commercialized have suffered particularly from the hands of man. Passenger Pigeons are extinct because they were shot, trapped and netted to extermination for food and for sport. Many game birds have been threatened with a like fate. Egrets and some other so-called birds of plumage, are rare to-day because of past demands for their feathers by the millinery trade. Despite the fact that numerous species have largely increased over their former numbers there is yet the greatest need for their still further increase. Our rapidly growing agricultural interests have resulted in vastly enlarging the varieties and numbers of injurious insects that prey upon the growing crop and the harvested products.

The National Association of Audubon Societies is intensely interested in this phase of conservation and wishes to use every legitimate means of bringing the subject of protecting our economically valuable birds again and again to the attention of the public. This book, being Volume II of the series which it is hoped to continue, is being brought out and offered at cost in the hope that it will further stimulate interest in American bird protection.

In this Volume there may be found discussions of the lives and habits of birds representing eleven of the seventeen Orders inhabiting North America.

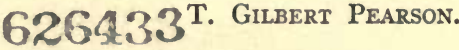





\section{TABLE OF CONTENTS}

SPOTTED SANDPIPER

Herbert $K$. Job

LEAST AND Semipalmated SANDPIPERS. . Herbert $K$. Job HORNED LARK .

SNOWY EGRET .

DOWNY WOODPECKER

RUBY-THROATED HUMMINGBIRD .

YELLOW-HEADED BLACKBIRD.

CALIFORNIA QUAII

NUTHATCHES

Willow Ptarmigan

CHICKADEe .

Hudsontan CurLew

RUFFED GROUSE

EMPEROR GOOSE

Crested Auktet

GREEN HERON

ALASKa LONGSPUR

BROWN THRASHER.

Tufted Pufrin

CATBIRD

Turted Trtmouse.

WOOD THRUSH.

WHIP-POOR-WIIL

Roseate Spoonbili

SORA.

Pintall.

Crow

Loon

TOWHEE

ChIPping Sparrow

KINGBIRD

BaLd EAgle

SURF SCOTTER .

SHOVELLER .

CHESTNUT-SIDED WARBLER

REDSTART

VEERY

AVocet .

BLACK-NECKED StTLT.
PAgE

201

205

209

2I 3

$2 \mathrm{I} 7$

22 I

225

229

233

237

24 I

245

249

253

257

26 I

265

269

273

277

28 I

285

289

293

297

301

305

309

313

317

$32 \mathrm{I}$

325

329

333

337

$34 \mathrm{I}$

345

349

353 


\section{Table of Contents}

\begin{tabular}{|c|c|c|c|c|c|}
\hline row & & & & & T. Gilbert Pearson \\
\hline AGE GROUSE & & . & & & T. Gilbert Pearson \\
\hline ITE-THROATED SPA & & & & & T. Gilbert Pearson \\
\hline Рноеве. & & . & & & T. Gilbert Pearson \\
\hline PILEated WoOdPeckF & & & & & T. Gilbert Pearson \\
\hline RA & & & & & T. Gilbert Pearson \\
\hline -COLORED JUNCC & & & & & son \\
\hline ERN & . & & & & T. G \\
\hline Bit & . & . & . & & arson \\
\hline ED-Eyed Vireo & & & & & T. Gilbert Pearson \\
\hline URKEY VULTURE & & & & & T. Gilbert Pearson \\
\hline
\end{tabular}




\section{ILLUSTRATIONS}

\section{COLORED PLATES}

Auklet, Crested.

Avocet .

BITTERN, LEAST

BlackBIRD, Yellow-HEAdED

CATBIRD

Chickadee, Black-CAPPed

Crow

Curlew, Hudsonian

EAGLE, BALD

Egret, SNOWY .

Goose, EMPERor

GRouse, RufFeD

Grouse, SAgE .

HERON, GREeN

HUMMINGBIRD, RUBY-THROATED .

Junco, Slate-Colored

KINGBIRD

LARK, HORNED.

LONGSPUR, ALASKan

LooN

Nuthatches, White-Breasted, AND RED-BREASTED

PhOEBe

PinTAIL.

Ptarmigan, Willow

Puffin, Tufted

QUAIL, CALIFornia

RAVEN

REDSTART

SANDPIPERS, LEAST AND SEMIPALMATED

SANDPIPER, SPOTTED

SCOTER, SURF

SHOVELLER .

SORA

SPARROW, CHIPPING

SPARROW, ENGLISH

SPARROW, WHITE-THROATED .

SPOONBILL, ROSEATE

FACING PAGE

258

350

390

226

278

242

306

246

326

$2 \mathrm{I} 4$

254

250

362

262

222

382

322

2 IO

266

310

234

370

302

238

274

$230-$

378

342

206 -

202 -

330 -

334

298

318

$35^{8}-$

366

294 


\section{Illustrations}

STILT, BLACK-NECKED .

TERN, LEAST

THRASHER, BROWN

THRUSH, WOOD

Trtmouse, Tufted

TOWHEE

VEERY

Vireo, Red-Eyed .

VULTURE, TURKEY

- Warbler, Chestnut-SIDEd .

WHIP-POOR-WILL

WOODPECKER, DOWNY

Woodpecker, Pileated

Auklets, at nesting place. Photographed by C. H. Townsend Avocet, nest and eggs. Photographed by $\mathrm{H}$. T. Bohlman . Avocet on nest. Photographed by H. T. Bohlman. . . BITTERN, LEAST, "freezing"

- BlackBIRDS, Yellow-headed and nest. Photographed by T. S. Roberts

CAtBird and Nest.

Chickadee, Young. Photographed by H. K. Job .

PAGE

258

$35 \mathrm{I}$

349

389

CROW on Nest

EAgle, Bald, Nest

Egret, Snowy, at Nest. Photographed by O. E. Baynard .

HUMMINGBIRD, RUBY-THROATED on nest

Junco

KINGBIRD's Nest and Eggs. Photographed by A. D. Whedon

LooN and nest. Photographed from Museum Group

2 I 3

22 I

$38 \mathrm{I}$

$32 I$

Phoebe on nest

PINTAIIS in flight. Photographed by $\dot{\mathrm{H}}$. K. Job

Redstart and Nest

SANDPIPER, LEAST, just Hatched. Photographed by H. K. Job

SANDPIPER, SPOTTED, on Nest. Photographed by H. K. Job

SPARRow, Chirping. Photographed by J. W. Lippincott.

Stilt, BlaCK-NECKED, Nesting Haunts.

Tern, Least Feeding Mate. Photographed by E. H. Forbush

Thrush, Wood, Nest and Eggs. Photographed by B. S. Bowdish

Thrush, Wood, Young. Photographed by B. S. Bowdish TowheE Feeding Young Cowbirds.

VEERY on Nest. 


\section{Illustrations}

PAGE

VIREO, RED-EYED, on nest. Photographed by F. M. Chap$\operatorname{man}$. . . . . . . . . . 393 Vulture, Turkey, Young. Photographed by T. H. Jackson 397 WARbler, Chestnut-Sided on Nest. Photographed by H. K. Job. . . . . . . . . . . . 337

Woodpecker, Downy. Photographed by C. E. Purple. . 217 WoodPECKER, Downy. . Drawing of Bill and Tongue. . 220 


\section{THE SPOTTED SANDPIPER}

By HERBERT K. JOB

\section{The National Association of Audubon Societies Educational Leaflet No. 51}

The sight of a shore-bird has always given me a peculiar thrill. In my boyhood I associated their bands with outings in summer or autumn on the seacoast, when I tramped for miles over stretches of firmly-packed sand by the booming surf on "the backside of the Cape" (Cape Cod), or explored great salt marshes, luxuriating in briny odors and listening eagerly for the pipings of an approaching flock. An added charm of mystery and travel lingered about these waifs, which were more at home on the shores of the Arctic Sea than on beaches made commonplace by hotels and merrymakers. They seemed to carry, like the lass of the proverb, a "delicate air," so clean, so trim, so graceful were they. Thus the Spotted Sandpiper, as one of these shore-birds, always brings to my imagination

\section{A Blessed Shore-bird} a sweet little whiff of the sea-breeze; even in a potato-field it is a blessed shore-bird still. and calls up impressions of the whole fascinating tribe.

In many parts of the country the race of shore-birds would now be unknown-have vanished like lost arts and extinct races-were it not for our dear little "Teeter," the Spotted Sandpiper, which is by far the commonest and most widely distributed shore-bird in North America to-day. In answer to the inquiry as to where it is found, I would ask the opposite question: Where is it not found? This is not to assert that it is swarming in every locality. Far from it, alas! But there is hardly a place on the continent, except in deep forest, where one need be surprised to run across it.

Like most other shore-birds, the Spotted Sandpiper is a great traveler. One would hardly suspect the little pair, settled down for the summer so tamely in a quiet farm-pasture, of being restless, and of craving the excitement of foreign travel; yet, for aught we can tell. these may be the selfsame birds that a certain explorer met last winter away down in Peru, or Bolivia, or southern Brazil. They are erratic in their movements and desires. Though many of them remain in the Northern States

\section{Erratio}

Migrants

well into October, other individuals show themselves by the end of July in the West Indies, Venezuela, or in Mexico. The returning tourists appear in northern Florida near the end of March; but it takes them more than a month to travel to the vicinity of New York, for there are no dining-cars on the routes they patronize, and they work their passage in thorough and leisurely fashion. 
Our little friend is readily recognized. -As it runs along the ground, or by the margin of a pool or stream, you know it is a sandpiper from its characteristic gait. All sandpipers are clad in grays and browns above, and in white below; but the Spotted Sandpiper, in adult plumage, has conspicuous streaks and spots sprinkled over the white plumage of the underparts. The young bird of the first summer and fall, however, is only indefinitely gray on the breast and sides. It is almost never at rest, for it has contracted a nervous habit of tilting its body incessantly. Standing on the shore, it bows, bobs, jerks, tilts its body, yes, "teeters,"

Attitudes and Flight we may call it. When it flies, too, it proclaims its identity. The wings are held below the level of the back with the tips well down, and are given a tremulous, hovering motion, accompanied by loud cries of peet-weet, peet-weet.

These traits have given this bird the names by which it is better known than by its book-name, such as Teeter, Tip-up, Peet-weet, and so on. I dislike, however, to record local names of birds, and thus help to perpetuate them and the confusion they cause, for it would be much better if every one of our birds was known by one generally accepted name.

The Spotted Sandpiper does not ask for the spacious lakes or broad streams that many of its tribe require. The merest puddle or rill will satisfy this species, and often we may run across it even in a dry pasture or on a piece of ploughed land. Just a little wetness of low ground may recommend a place as suitable for a summer home. Yet the bird is far from averse to more water. One is almost sure to find it running along the margin of a pond, lake, or river ; and the ocean-beach, particularly when rocky, is attractive to it. In such places, when the nestingseason is over, and the young are able to take care of themselves, we may meet these Sandpipers in family parties, or in small flocks, not in compact bodies, like various other sandpipers, but scattered; and single ones are sometimes found associated with flocks of other species. When

Family alarmed, the scattered company springs suddenly Parties from the shore, circles out over the water, with reverberating peet-weet cries, and returns to a spot not very far from the starting point.

On the small inland waters there is but one species with which this could readily be confused. This is the Solitary Sandpiper, a bird not at all plentiful, which appears, usually singly or in pairs, as a migrant in May, and again in August and September. A careful observer readily may learn to distinguish them. Once I had a fine opportunity to see both species together and note the differences. It was late in July, on Lake Chautauqua, New York, on the grounds of the Chautauqua Institution. The bird-study class was out before breakfast, and was delighted to see a flock of shore-birds resting on a sand-flat, among them Spotted Sandpipers and several Solitary Sandpipers. Behind some large trees we made a close approach, and could see distinctly that the Solitary Sandpipers were a trifle larger than the Spotted Sandpipers, were darker on the back, 
and had green legs instead of yellowish ones; they were also quieter in voice and manner than the latter.

During the last half of May at Chautauqua we are likely to happen on early nests of the Spotted Sandpiper. The site most likely to be selected by this bird is under a bunch of weeds, or in the shelter of coarse grass, a few yards or rods back from the shore of a pond or stream; but often the chosen spot will be in a moist pasture, or even in a field of potatoes or

\section{Nesting-}

Resorts

corn. Time and again I have found nests on islands, both in lakes and in the ocean, sometimes a dozen or twenty on one islet.

Some nests are concealed very carefully, amid thick foliage, while others are merely in the shade of some straggling weed. The best concealment for the eggs is afforded by the demure little brownish motherbird whose plumage blends perfectly with the color of the ground as she sits motionless upon her treasure; but let one walk too close, and away she goes, uttering her shrill peet-z'eet alarm. Then the secret is out, and the trespasser may examine the four eggs, large for the size of the bird, whose creamy-white background is plentifully sprinkled with dark brown spots, especially at the larger end.

One day, early in June, my wife and son were following an overgrown cart-path, just in from the bank of the river, when they flushed one of these Sandpipers from a nest with four eggs situated under a small clump of weeds. Close to it was a pile of slag and rock, dumped from an old foundry many years before. It seemed to me, when I examined it, an

Photographing

a Sandpiper ideal place to secure photographs of the bird on her nest.

So I piled slag and weed over the camera, and, connecting a thread with the shutter, I hid myself behind a thicket of bushes some fifteen yards off. In a few moments the little Sandpiper appeared, trotting about and jerking her body, I thought, even more nervously than usual. She hesitated for some minutes till she felt assured that I had gone. Then she walked straight to her nest, going within a foot or two of the camera, which she failed to notice at all, so well was it concealed. When she reached the eggs she settled over them at once, bristling her feathers and pushing her treasures with bill and wings this way and that till everything was arranged to her satisfaction. Then came my chance, and I pulled the thread gently. taking her picture. Even the slight click of the shutter sent her off in a hurry, but she came back several times for me, and then I left her in peace. She safely brought off her young, and afterwards I met them scurrying along the margin of the river.

As with all baby shore-birds, the young Spotted Sandpipers are quaint and amusing. They look like tufts of cotton stuck up on toothpicks as they race over the sand, attempting to escape when discovered. First, though, when a stranger approaches, they squat flat on the shore, or hide in the grass. The parents throw themselves on the ground before 
their supposed enemy, and "make believe" to be wounded, so as to decoy him away from the young; and they are apt, in their solicitude, to alight in all sorts of places, even upon trees or bushes.

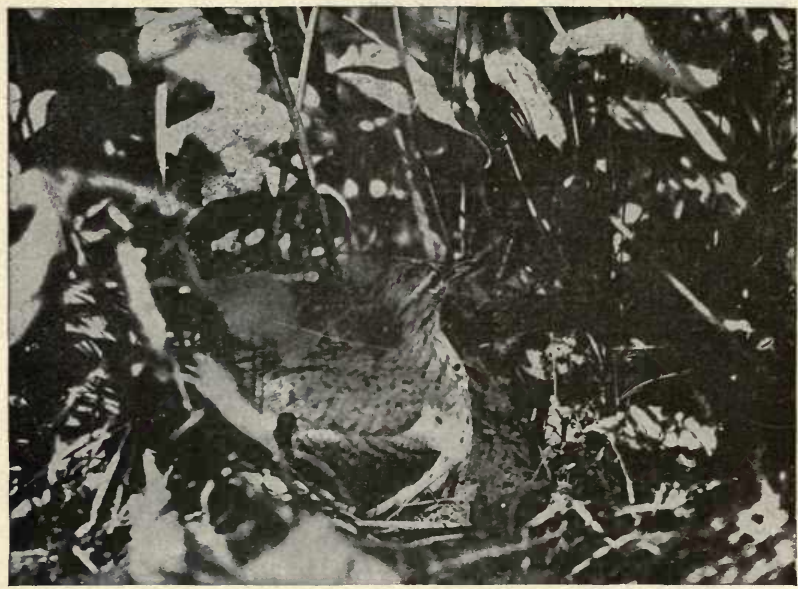

A SPOTTED SANDPIPER SETTLING UPON HER EGGS

Fhotographed by Herbert $\mathrm{K}$. Job

The usual food of most shore-birds is aquatic insects; but the Spotted Sandpiper is also a bird of fiells and pastures, and therefore its range of insect-food is wider than most of its tribe, and includes grasshoppers and locusts. Probably almost anything in the insect line is acceptable, and thus it is a most useful bird to farmers: indeed, our

Food and shore-birds are not given credit enough for the good Service that they do to agriculture. The Killdeer, Upland Plover, and Spotted Sandpiper should be classed with the Meadowlark and Bobolink; and not be put in the game-bird class at all.

The ruthless way that the shore-birds have been exterminated is truly shameful. It is high time to give all the shore-birds protection, lest species after species, now seldom seen, go to a sad extinction.

\section{Classification and Distribution}

The spotted Sandpiper belongs to the Order Limicole and the Family Scolopacida-Snipes and Sandpipers. Its seientifie name is Actitis macularia. It ranges over the whole continent, and breeds from Alaska and the wilderness about Hudson Bay south to the borders of Mexico; and it winters from the Gulf States to southern Brazil.

This and other Educational Leaflets are for sale, at 5 cents each, by the National Association of Audubon Societies, 1974 Broadway, New York City. Lists given on request. 


\section{LEAST SANDPIPER}

AND

\section{SEMIPALMATED SANDPIPER}

BY HERBERT K. JOB

\section{The National Association of Audubon Societies}

Educational Leaflet No. 52

These two dainty little Sandpipers, smallest of their tribe, may well be considered our representative shore-birds. The flocking of restless bands of nimble sprites along the sea-coast and the larger inland bodies of water is one of the most attractive sights in nature. Such a species as the Spotted Sandpiper, though commonly seen running along streams during its summer stay, does not gather in large and compact flocks; so that it is rather through the Least and the Semipalmated Sandpipers that the majority of persons who see shore-birds at all become familiar with the pretty company that races along and across the beach, chased

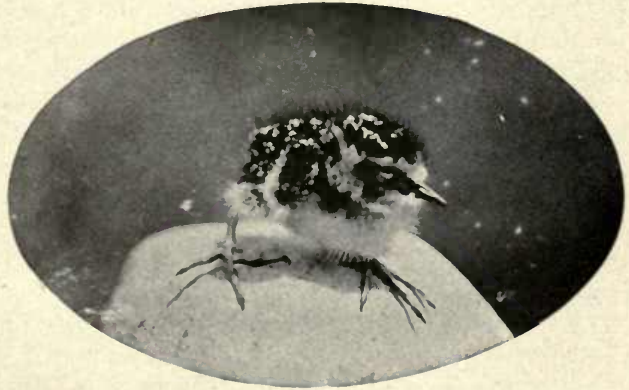

A LEAST SANDPIPER JUST HATCHED

Photographed in the Magdalen Islands by Herbert K. Job

by the waves, and with their masterly flight. The larger shore-birds. alas! have been pretty well shot off, and in most parts of the country are found, if at all, in small numbers, only in favorable spots, and by the initiated. These tiny species that we are now considering remain the commonest of their fanily, because the least attractive to gunners.

They are too small for food purposes, and no one deserving of the name of sportsman will, in these days, fire at their diminished ranks. Nevertheless, they are in nothing like their former abundance. Instead of the flocks of hundreds with which I was formerly familiar, two dozen now is a large flock in many places, and rarely enough at that. 
There is a peculiar charm connected with the migrations of these birds. They are so tiny and delicate, yet withal so strong and sure in their flight, so able to dash with amazing swiftness past coasts and over the trackless ocean, and to reach the extremes of continents. They come in April or May, according to latitude, with the aroma of the tropics, and return in late July to September with the tang of the arctic wild. In the southward flight, the Semipalmated goes as far as Patagonia, while the

Extensive

Migrations

other is known to reach Chile. Some winter as far north as the Carolinas, and I have found them common on the codst of Louisiana in January. For breeding, they wing their way mostly far northward, even to the shores of the Arctíc' Ocean, but some remain further south. The Semipalmated

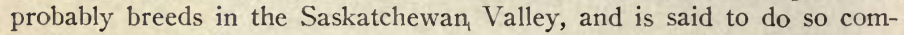
monly along the southern and western shores of Hudson Bay. The Least breeds sparingly on Sable Island and elsewhere in Nova Scotia, on the Magdalen Islands in the Gulf of St. Lawrence, and northward. In migration, it is found over the entire continent, while the Semipalmated species remains mostly east of the Rocky Mountains.

While I have not been privileged to study the Semipalmated Sandpiper on its breeding-grounds, I have had good opportunities with the other species. As both are said to be much alike in their nesting habits, an account of those of the Least Sandpiper may suffice for both.

It was on the Magdalen Islands that I first became intimate with this wee sandpiper. To appreciate the conditions, one must imagine a barren, open expanse, with a temperature cool, even in midsummer, and plenty of chilling fog. For miles it is moist ground, carpeted with sparse grass and spongy moss, and diversified with occasional patches of stunted spruce or low, sprawling juniper. Billowy elevations of sanddune in the distance are overgrown with beach grass. In these lower parts are numerous shallow lakes, from a few yards across to a mile long, the larger ones with borders and areas of reeds or rushes. Small

An Island Home parties of Least Sandpipers, or single ones, probably males, feed beside these lakes or pools. The females are closely brooding their eggs, which here on the Magdalens are laid during the first half of June, when the temperature of the air is about $50^{\circ} \mathrm{F}$.

The experience of finding the first nest of this little arctic bird will always be memorable. As we tramp over the dark arctic moss, we notice a pretty little twittering, and discover a tiny Sandpiper flying around in wide circles on tremulous wings, pouring forth the music that presents the emotions of his little heart. It is the love-song to his mate, who is covering the eggs not far away. We long to find the birdtreasure, and tramp all about, hoping to flush the brooding bird. Our wish is gratified. Inadvertently we have almost trodden on the nest. Away flutters the tiny bird, almost from under our feet, not in rapid flight, but dragging herself over the grass as if she were almost expiring. The nest is a rather deep little hollow in the moss, lined with grass and 


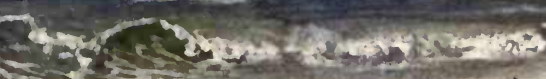

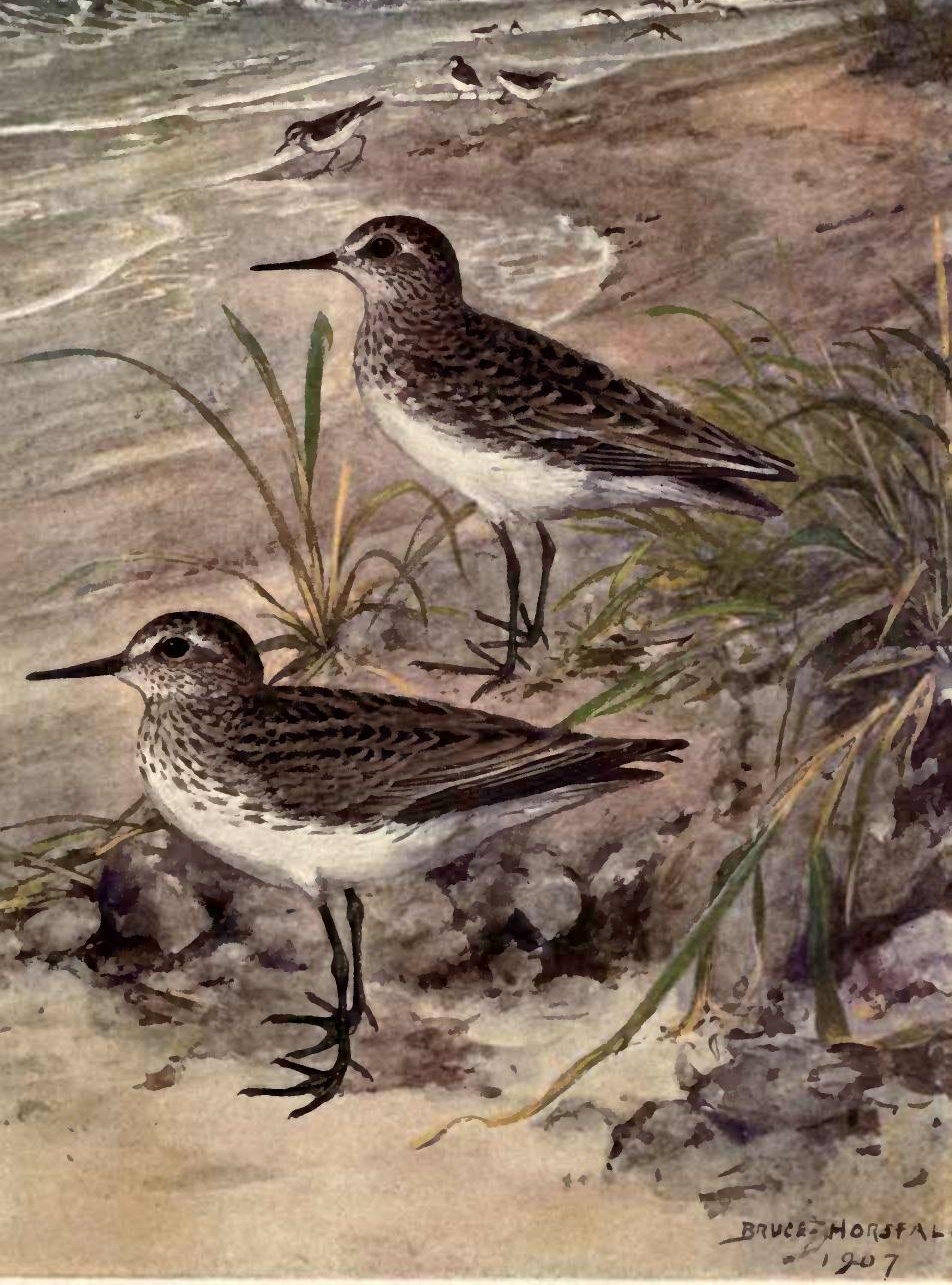

LEAST SANDPIPER (Upper figure)

SEMIPALMATED SANDPIPER (Lower flgure)

(One-half natural size)

Order-LimicolNe

Pisobia MiNutilla (upper fig.)
Family-Scolopacide

ERBUNETES pUsillus (lower fig.)

National Association of Audubon Socteties 


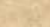

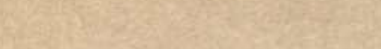

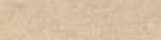




\section{Two Sandpipers}

bayberry leaves. The four pear-shaped eggs look very dark-a drab background, heavily mottled with brown or black. Madam soon returns with her husband, and both trot around near by, piping their complaints at our intrusion. On one memorable occasion, by setting my camera focused on the nest, I obtained a picture of the brooding mother.

The chicks are the daintiest little mites that one can imagine-little brown balls mottled with white, and comical enough they are, perched up on the rather long, slender stems that pass for legs. Frequently they are hatched in the wet pasture-land close to the cottages of the fishing settlements. While walking along the road and approaching the house where we were stopping. I saw a pair of these Sandpipers acting as if very anxious, alighting on the posts and top wire of the fence, piping their complaints. Well did I know what was up, and after a considerable hunt I found the four chicks lying close together, flat on the ground. The

\section{A Sandpiper Nursery}

little Sandpiper might not be averse to civilization, if unmolested; but what chance does such a brood have near houses against prowling cats!

The nesting season of these Sandpipers-and, for that matter, of all the shore-birds-is very brief. Such small species do not take long to mature. Thus surprisingly early in the summer. often soon after the middle of July, they begin to straggle back to us, as if the arctic wilderness were too cold and lonely to interest them longer.

As far as I am familiar with the shore-birds the adults precede the young on the southward migration, leaving their guileless broods to follow as best they may. In species where differences of plumage between old and young are conspicuous, this is very noticeable. The adults of the Ringneck or Semipalmated Plover. for instance, pass us in New England mostiy in August, and seldom do we see the pale-banded youngsters before September. The Golden and Black-bellied Plovers have a similar practice. But how do these unsophisticated young of the Sandpipers find their way to their unknown habitat in the far South? 'Who. indeed, can really tell!

These two tiny species flock more or less together-as well as in company with other shore-birds-and it is not easy to tell them apart. The Least lacks the partial webbing between the toes, but this can hardly be observed at any distance. It is a trifle smaller than the Semipalmated. and has a reddish-brown tint in its plumage, while the other tends rather to gray; also it is perhaps more fond of marsh and meadow than the Semipalmated, which favors beaches and flats. Both, however, are often found on the marsh, so this sign is by no means of general application.

It is a wonderfully pretty sight to watch them scurrying away from the advancing waves on the grand. gray sea-beach, or paddling nimbly about on the flats or in shallow pools of the marsh. How they can make their little legs go! As we walk along. we may not notice the birds, they are so small. Suldenly arises a shrill twittering or lisping, and up darts the scattered party of Sandpipers. Quickly they get to- 
gether, and in a rather compact flock are off at a rapid rate, their little wings moving so rapidly that it takes a high speed of the focal-plane shutter to get them sharp on the plate. Circling about, they often return to alight near their starting-point.

Speaking of photography, the shore-birds are a hard class to catch successfully with the camera, because so small, restless, and dwellers in wide expanses. Not many hunters with the camera can produce good photographs, self-taken, of this tribe. It can be done, however, and these little Sandpipers make very pretty subjects. One can attract them to a blind with decoys. I have even had them fly close to Duck decoys, and secured good pictures of them thus, though it probably was mere idle curiosity that drew them. The best chances I ever found to photograph these and other shore-birds, except at nesting time, was on the spring migration among the Florida Keys, where the red mangrove grows

\section{Photographing Shore-birds}

right down to the water's edge, close to the sand-bars. In winter and spring they are numerous in such places, and all I had to do was to squat quietly and blaze away with my harmless weapon as the unsuspecting birds ran by me, fed, or rested.

These little nymphs are gleaners, rather than scavengers. Their food, of course, is of very small prey-larvæ, worms, minute shell-fish, insects, and the like-which they pick up on shore or flat, or probe for deeper down. Though we may not be able to assign any definite economic value to these species in dollars and cents, they have a value none the less real and great. Celia Thaxter found genuine happiness with "One little Sandpiper and I!"-and so has many another. They have afforded me, hundreds of times, most exquisite delight, and I know that they are worth while. May their numbers greatly increase!

\section{Classification and Distribution}

These Sandpipers belong to the Order Limicole and Family Scolopacida.

The scientific name of the Least Sandpiper is Pisobia minutilla. It breeds in northern and eastern Canada, and in Alaska, and winters from the southwestern border of the United States to Brazil and Chile.

The sciantific name of the Semipalmated Sandpiper is Ereunetes pusillus. It breeds in the Arctic regions, and winters from Texas and South Carolina throughout Central and South America.

This and other Educational Leaflets are for sale, at 5 cents each, by the National Association cf Audubon Societies, 1974 Broadway, New York City. Lists given on request. 


\title{
THE HORNED LARK
}

\author{
BY EDWARD HOWE FORBUSH
}

\section{The National Association of Audubon Societies}

\section{Educational Leaflet No. 53}

It is November. On Martha's Vineyard, a little island south of Cape Cod, the boiling surf pounds and roars along the lonely shore, shifting the sands upon the bars and rattling the cobbles on the cold, stony beaches. Surf-ducks dive and play amid the white-capped seas, while the Atlantic stretches away in the dim distance to the home of the east wind and the storm.

Inland, among shrubby plains and rolling hills, nestles an isolated farm. Here in a weedy field, sheltered somewhat from the searching winds of the Atlantic, a flock of little brown birds creep in and out among the stubble. They have come from their summer home, in bleak and barren Labrador, to their harvest home in this sea-girt isle. They are Eastern Horned Larks, the type of the species.

Anyone acquainted with bird-life in Europe would at once recognize this little pedestrian to be a close ally of the far-famed Skylark. It is a small bird measuring only seven and three-quarter inches in length, and its weight does not exceed one and one-fifth ounces. Yet though so small a bird it attracts attention wherever seen.

It is April. The setting sun lies warm over the wide prairie-fieli!s of Minnesota, and the light, free, south wind gently breathes the breath of life over an eager land. A little bird sits on her sunken nest in the prairie sod, watching her mate as he springs aloft and gives himself to the buoyant currents of the air. He swings in loose circuits and zigzags back and forth, singing gently at first, then, fluttering upward, rises by stages, taking

Song-

Flight each upward step at a steep slant, sailing, 'gyrating, mounting higher and still higher, pouring forth his whole soul in an ecstasy of song.

$\mathrm{Up}_{\mathrm{p}}$ and up he goes, swinging in dizzy spirals, pausing at one height after another to send back to earth his music; and so soars and sings until he fades from view in the clear blue canopy of heaven, and the song is wafted down sweeter and fainter until, like the skylark, he sings at "heaven's gate."

Then, as the full food of his ecstasy begins to ebb, and his strength wanes, he sinks slowly down; the far-away song swells on the listening ear, and, still fluttering and singing, he comes again into view. Swing- 
ing in wide aërial circuits he drops by slow stages until at last his hymn is ended, and, closing his wings, he drops like a meteor until near the earth, when he spreads his wings, checking his headlong rush, turns, and swings along the sod until his toes touch the grass-tops as lightly as the summer wind, and he comes to earth again near the little nest, the center of all his hopes.

Such is the song-flight of the Prairie Horned Lark-a wonderful performance. The last stanza of Shelly's "Ode to the Skylark" might well be applied to its American cousin:

"Leave to the Nightingale her shady wood;

A privacy of glorious light is thine.

Whence thou dost pour upon the world a flood

Of harmony, with instinct more divine;

Type of the wise, who soar, but never roam-

True to the kindred points of Heaven and Home."

The true larks, of which the Horned Lark is an example, have a long, straight claw (the "lark-spur") on the hind toe, and a slightly crested head; but Horned Larks have in addition over the eye, and extending to the back of the head, a pair of narrow, black, Characteristics pointed crests that ordinarily lie close to the head; but when the male is excited by passion or surprise these crests are erected, so that his head resembles slightly that of an owl, with two little black ears sticking up.

Almost everywhere in the treeless lands of North America Horned Larks are found. In the East they breed southward to West Virginia, and in the West to Kansas, New Mexico and California.

In the time of Wilson and Audubon only the typical Horned Lark, or "Shore Lark," a bird of the Atlantic coastal region, was known in the East; but since then a somewhat different western subspecies, the Prairie Horned Lark, has expanded its range to the eastward. As the easteril country was cleared and settled, more open ground to which it had been accustomed became available there for this subspecies; and, as the western country was settled, trees were grown, much land was put under constant cultivation, thousands of larks' nests were destroyed as the farmers turned the prairie sod, and less room remained for this lover of the open grass-lands. Possibly for these reasons it

Change of Range has gradually extended its range eastward to Quebec and New England. It is a rather pale variety, with some white about the head in place of the yellow of the typical eastern bird. The "Desert" subspecies is also extending eastward.

The beginner in bird-study may not recognize the Horned Larks by their flight or by their whistled notes, for both resemble those of the American Pipit, or Titlark; but he may know them when they are on the ground by their pinkish-brown color, their thick-set. square-shouldered look, their mouse-like movements, and the distinct black and yellow, or yellowish-white, markings shown by the male bird on the side of the head. 
$\therefore$ if the $x^{h} \quad 1 \%$

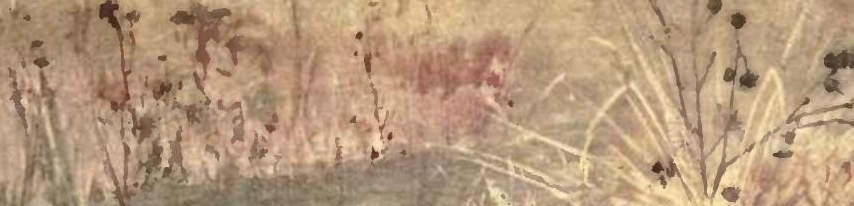

ans 4 of

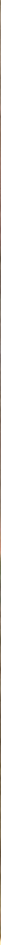

HORNED LARK

Ordor-PASSERES

Family-ALAUdidR

Genus-Orocoris

Specles-ALPRSTRIS

National Association of Audubon Socioties 

They may be confused with the Pipit or the Vesper Sparrow because of the white outer feathers of the tail; but the white in the tail of the Titlark and Vesper Sparrow is more noticeable, and the Horned Lark is much larger than either of those birds. As the bird flies overhead, the black tail with its white corners contrasts with the white belly. All this refers to the typical Horned Lark (Otocoris alpestris alpestris), a bird of the Northeast and Labrador; but all Horned Larks resemble the type in their markings. There is a great variation, however, in the shades of the plumage.

The ordinary call-note of the Horned Lark is very similar to that of the Pipit, but not so soft. Dr. C. W. Townsend writes it tsswee it, tsszut-a sibilant note. The flight-song of the Labrador Horned Lark is described by Townsend and Allen as a series of squeaks and high notes, with a bit of a fine trill, the bird beginning his song when high in air and ending

Sprightly

Notes

it there. The Prairie Horned Lark seems to be the best singer of them all. Its common song is a sprightly little ditty, with no considerable resonance or modulation. Dawson expresses its proportions and tempo by the syllables, tzidge-zvidge, wigity wigy-zidge, while the words twidge, zeigity, eelooy, eclooy, idgity, eelogy $e$ e $w$, serve the same purpose for the rarer ecstasy-song, which is sometimes given on the ground, but usually in air.

The nest is built in a hollow dug in the ground or sunk in the moss, and is so deeply hollowed that the back of the sitting bird comes level with the surface. It is built chiefly of dried grasses, and that of the Desert variety has a curious "paving" of chips, etc., about it, described by Henry Mausley, in The Auk, July, 1916. The Prairie Horned Lark begins her nest early in March or April, by digging a hole about three inches wide and nearly as deep. This is lined to a depth of nearly an inch with dry grass, and the top is usually left level with the surface.

The eggs, from three to five, are about one inch in length and from .60 to .75 inch in diameter. They are variable in color, but are usually profusely and heavily marked with brownish gray or dark stonegray upon greenish bronze. When the eggs are nearing the end of the incubating period, the bird sits so closely as almost to allow the intruder to step upon her back.

Audubon found the Horned Lark breeding in high and desolate tracts of Labrador near the sea, on dark rocks covered with mosses and lichens, where its protective coloring, as it sat on the nest. was quite as effective as it is

\section{Nesting \\ Place} among the pastures of New England, or on the broad and breezy western prairies.

As the young approach maturity they outgrow the nest, and when it will contain them no longer they leave it, usually several days or a week before they are able to fly; after which they wander about over the ground, and the parents continue to feed them for two or three weeks. 
While the young are still in the nest the mother is very secretive about feeding them. She never flies to the nest when she apprehends danger, but always alights at a distance, zigzags up to the nest, creeps to it, feeds the young very quickly, and then steals away. The little ones in their first plumage are covered with light spots.

The Horned Larks are ground-birds. Although sometimes one alights upon a stump-root, fence-post, or rail, they rarely have been seen in trees.

In October, or when the chill winds of November blow, Horned Larks from the north begin to appear in the United States. They come down from Labrador and the fur countries and become common along the Atlantic seaboard, usually in small straggling flocks. The members of a flock keep company like a hen and chickens, the old birds leading. Sometimes as many as one hundred or more may consort together.

In the East they frequent freshly .ploughed fields, marshes, meadows, stubble-fields, and weedy places along the coast, sometimes going to the higher pastures. When snow comes they search for food along the shore, on bare spaces in roads, or near barns and haystacks. In winter they are sometimes seen in the interior with flocks of Snowflakes. In autumn and winter they are rather silent; and when feeding they keep close to the ground, where they creep about,

Winter

Habits picking up seeds. They are adepts at hiding, squatting low behind weeds or clumps of grass. The scattered flocks fly with an undulating motion, and when startled often rise, fly off, and then turn about and alight near the point from which they started.

In the West, they live in desert-valleys, on barren table-lands and level prairies, and also among highlands and upon bare mountain-peaks.

W. L. McAtee of the United States Geological Survey, in his bulletin on "The Horned Larks and Their Relation to Agriculture," states that two fifths or less of their food consists of insects, and four fifths of vegetable matter. The quantity of grain taken is insignificant except in California, where these birds seem to be largely vegetarian.

The Horned Larks are interesting birds. They readily adapt themselves to farm-conditions, and are distinctly beneficial to agriculture. They should be protected by law at all times.

\section{Classification and Distribution}

The Horned Lark belongs to the order Passeres, Suborder Oscines and Family Alaudida. Its scientific name is Otocoris alpestris. The range of the species includes all North America, Central and northern South America, northern Asia, Europe and northern Africa. Fourteen geographical races have been named as subspecies in North America alone, indicating unusual variability in this bird. 
in length and are straight. In the case of the Snowy Egret they are scarcely more than six inches long, are very fine, and are recurved at the tips. These are known among milliners as "cross aigrettes" to distinguish them from the "long white." The plumes appear early in the year and the birds begin to drop them shortly after the young are hatched. At the close of the nesting season the large Egret rarely Cross
Aigrettes possesses any plume-feathers, the forty or fifty nuptial plumes that adorned the bird earlier in the season having been shed during the course of the summer.

In the case of the Snowy the plumes fall out more slowly, and some individuals at least are supposed to still carry them when in autumn they leave our shores for the Tropics.

Snowy Egrets are found in swampy and marshy parts of tropical and sub-tropical America. They inhabit both fresh-water and salt-water marshes, and, unlike their larger relatives, even breed over salt water. They gather in colonies in the spring, and usually are found associated with Louisiana Herons and Little Blue Herons.

In visiting Heron colonies, or "rookeries," I have never been able to distinguish positively the eggs or nest of these three species. The only sure way of identification is carefully to watch a nest until the old bird not merely alights on the nest, but actually sits down and begins to brood the eggs. It should be borne in mind that simply because one sees a bird standing on a nest it is no infallible evidence that the nest belongs to that bird. Man-o'-war-birds are not known to lay their eggs anywhere on the coast of the United States, yet in Tampa Bay they have frequently been seen sitting on Cormorants' nests.

The nest of the Snowy Egret is made of twigs. Some of these may be a foot or more in length, especially those that make the foundation. Near the top the twigs become shorter and smaller, although there is

Nest and Eggs usually a ragged rim of sticks that project out at all sorts of angles. This is all. There are no feathers, leaves, fragments of moss, down or plants, or any of the softer materials that make beds for so many other kinds of baby birds.

On this thick, loosely constructed platform of twigs the four or five blue eggs are laid. The young at first are quite helpless, and after they begin to gain strength and sit up many days elapse before their long, wobbly legs are strong enough for the birds to stand on. Their toes are very long and the young at first move around in a most awkward manner. Were it not for the twigs that project everywhere from the sides of the nest many fledglings surely would be drowned. One may frequently see them with their necks hooked over one of these outlying twigs, and their long legs working convulsively as they seek to grasp the nest with their toes in an endeavor to regain a position on the platform.

Most Heron rookeries are infested with "cotton-mouths," or watermoccasins, and I have seldom visited a rookery that did not contain alligators. These reptiles not only are on the lookout for food that the 

birds let fall, but undoubtedly they eat many of the young Egrets that fall from the nest. I have been told by wardens that alligators sometimes shake or jar the bushes with the object of spilling the young birds out; of the truthfulness of this statement, however, I know of no satisfactory proof.

Young Egrets are fed chiefly on small fish, which the parent regurgitates into their mouths. The old Egrets in gathering food for themselves or young often make journeys of several miles from the rookery to their favorite feeding-grounds, where they get their prey while wading in the water. Ordinarily you need not expect to find them feeding where there are many trees, as for example in a swamp, nor on shores the borders of which are paved with sand or pebbles, but you must go to the marshes. Here, where often the water is only a few inches deep, the small life found

Marsh

Feeders

about the submerged bases of the marsh grasses provides food for the minnows that the Egrets love. Some members of the Heron family have the habit of standing still and capturing the fish that swim near them, or they will stalk through the water, very stately and dignified, keeping an eye out the while for any finny prey.

The Snowy Egret appears seldom to employ these methods. On the Orton plantation, in southeastern North Carolina, there is a pond a few miles in length, the dam for which was built by negroes in the days of slavery. This body of water is used for flooding the rice-fields of the plantation. It is a famous place for bird-life. In one of the narrow arms of the pond, which runs back into a cypress swamp, there is situated a rookery of perhaps two thousand Herons of different species. Should you visit this colony some day in May you would be able after a little watching to see a number of Snowy Egrets caring for their young. The parents are continually coming and going at all hours of the day. You may see a solitary Snowy Egret come flying in over the lake, go to its nest, feed its young, preen its feathers for a time, and then start off for more food. Nearly all of them come from the same direction. Not long ago I dis-

Care of Young covered their favorite feeding-ground. It was a brackish-water marsh close to the ocean, and about fifteen miles from where the birds had their nests.

One day I hid in a tall clump of grass to see what would come near. I had not long to wait before a Snowy Egret lightly dropped into the water not a hundred feet away. Evidently it was hungry or knew that its young were, for it immediately began a most vigorous quest for minnows. With the most astonishing agility it ran here and there through the water, its bright yellow eyes evidently discovering many objects of interest. With lightning-like rapidity the bill shot downward for minnows, and I suspect it rarely missed its prey. A Louisiana Heron came along and began feeding near by. The Snowy rushing here and there suddenly found itself face to face with its more sedate neighbor. In- 
stantly it showed resentment; the long feathers on its head were raised and the great mass of recurved plumes was elevated and spread out, forming an elegant fan-like ruff across the back and sides. Also, it promptly charged the Louisiana Heron in so fierce a manner that that disconcerted individual hurriedly fled to a safe distance.

The Snowy Egret is no small bully in the rookery, as many a venturesome Heron knows to its sorrow. Let a Little Blue or Louisiana Heron get too near a Snowy's nest, and it quickly finds itself in trouble. These birds also spar much with each other, and a group of them about their nests presents an animated scene.

The Snowy Egret formerly bred as far north as New Jersey and Former possibly Long Island, but this was many years Range ago. At the present time we know of no colony of this species north of Core Sound, North Carolina. There are several rookeries in South Carolina, one of which, that in the summer of 1917 contained about four hundred inhabitants, is on a small island in the Stono River, near Charleston. The island is owned by the National Association of Audubon Societies, which keeps a guard there during all the period of nesting. If this was not done the colony would be destroyed by gunners, just as the birds in hundreds of other rookeries have been exterminated. The "aigrettes" that come from the back of one Snowy Egret, and which are most perfect in the nesting season, can now be sold for ten dollars. It is easy to see, therefore, that the four hundred birds breeding on the Audubon island in the Stono River would bring four thousand dollars in the millinery markets.

Knowledge that money can be derived from killing the birds makes a strong temptation to some classes of gunners to slip into the rookeries and shoot the birds, if they can catch the warden away. Nearly every

\section{Audubon}

Warden-Service summer there is a fight between the Audubon wardens and would-be poachers. In these encounters two wardens have been killed and others wounded. It is, of course, against the law to kill the birds, and also it is illegal in many States to sell their feathers.

The largest nesting-colony of Snowy Egrets in the United States of which we have any knowledge is situated in a pond on the estate of Mr. E. A. McIlhenny at Avery Island, Louisiana. Prof. J. S. Huxley went carefully through the rookery in the summer of 1916, and reported between eight hundred and nine hundred nests.

\section{Classification and Distribution}

The Snowy Egret belongs to the Order Herodiones and to the Family Ardeida. Its scientific name is Egretta candidissima. It formerly ranged throughout the southern half of the United States except the dry plains, and all over South America; but is now restricted in North America to the South Atlantic and Gulf States. It winters from Mexico and southward.

This and other Educational Leaflets are for sale, at .5 cents each. hy the National Association of Audubon Societies, 1974 Broadway, New York City. Lists g.vin on request. 


\section{THE DOWNY WOODPECKER}

By T. GILBERT PEARSON

\section{'The National Association of Audubon Societies} Educational Leaflet No. 55

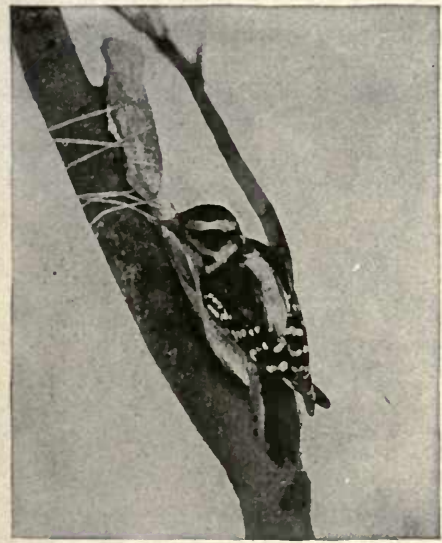

Downy at Dinnre

Photographed by Carl E. Purple

A cheery little neighbor of mine lives near me, among the trees of a grove, whom I should like to have all my friends meet. $\mathrm{He}$ is a little Downy Woodpecker. White spots are scattered over his black wings, and there is just a stripe of red across the top of his black cap. I am sure you would know him by his small size, his colors, and his trustful manner. $\mathrm{He}$ is not at all suspicious, and when he is hard at work will usually allow one to approach quite close to him. If you will tie a piece of suet to the limb of a tree, as Mr. Purple had done before he made the photograph shown on this page, Downy will come to see you day after day, especially in winter, when he is exceedingly glad of your bounty.

$\mathrm{He}$ is a quiet, modest, little creature who never does anyone harm, and so far as known has few enemies, the most alarming one being the snake that robs his nest.

Downy is the smallest as well as the most active of our woodpeckers, and appears to be always busy. Often we may sce him climbing up the huge trunk of some old oak-tree, pausing a second here and there to rap on the bark with his bill to learn whether the wood is solid. Again he will pause as the peculiar sound given back from his tap indicates that an insect is lurking within. Then the resounding blows of his little pickaxe fall thick

Sounding the Trees and fast, sending the chips in every direction.

In vain does the larva feasting on the sap of the tree retreat into its hole. A gleam of daylight shoots into the burrow, and an instant later the spear-like tongue of the Woodpecker has impaled its victim and jerked it forth. Then on up the tree Downy goes, perhaps without further incident until well among the limbs, when suddenly he flies to a neighboring tree, dropping as he does so to a point near its base, and begins to ascend this trunk as he did the one before. 
He is the natural watchman of our fruit-trees. He hunts out the moth's eggs laid in the crack of the bark and eats them, thus preventing a brood of caterpillars from hatching and eating the leaves of the tree. He finds the eggs of beetles and eats them, also, before they can hatch out into the wood-boring larvæ that sometimes girdle and kill the limbs. Thus Downy labors on, day by Insects
Destroyed day, through the year, destroying millions of harmful insects that if unmolested would do a vast injury to the groves and orchards. For all this service he never eats any of the fruit of the trees he guards, but, when in need of a little vegetable diet, goes to the berries of the dogwood, or woodbine, or pokeberry. Occasionally he eats a few weed-seeds just for variety. Downy is sometimes called "Sapsucker," and is accused of pecking holes in the bark of trees for the purpose of getting sap. But he is not the guilty one-the bird that does this is another kind of woodpecker. The smail holes that our little friend makes in trees do not even reach the inner bark, except when he is bent on securing some harmful intruder.

Like most of our woodpeckers Downy is a resident throughout the year wherever found, and seems to enjoy all seasons equally. Early in December one dug out with his bill a cavity for his winter bedroom in the dead limb of the tree standing near the house. So nice and cozy a retreat from the wind was it that frequently, early in the evening, he would leave his friends, Chickadee and Titmouse, with whom he had romped all day, and, hurrying off, tumble into bed to dream away the long winter night. On cold and rainy mornings he would sometimes lie late abed, probably knowing that in doing so he stood no danger of losing the early worm. I found him still there about nine o'clock one drizzling morning; to be sure, he was up and about, but he had not yet left home. He was clinging just inside the hollow of the limb, and I could distinctly see his bill and bright inquisitive eyes as he sat looking out over the drenched and dreary world.

When you find Downy in your orchard on a bright, cold morning in January, he has the same busy, contented air which you must have noticed when first making his acquaintance, perhaps on some warm spring day. He appears so happy and buoyant at all times, however,

\section{Downy and}

his Friends

that. one wonders whether he has not hidden away under his little white waistcoat a perpetual fountain of the ecstasy of springtime and youth.

He likes cheerful company, especially in the winter, when most of the forest-voices are silent and the cold winds are howling around the trunks of the sleeping forest-trees.

He then hunts up his friends, the little gray Tufted Titmouse and the light-hearted Chickadee. Together they spend much time in bands, patrolling the woodland, and searching out from their hiding-places the eggs of insects stowed away under the bark to wait for the warm spring sun to hatch them. A dozen or more birds are thus often found together. 


They form a merry company, these little forest-rangers, and never lack for music as they march. The shrill piping peto, peto, peto, of the Titmouse mingles with the tenor-drum tap, tap of Downy's bill on the bark, while ever and again the Chickadee, a mere bundle of nerves and fluffy feathers, "merrily sings his chick-a-dec-dee."

Not merely for company do these birds thus associate, but for mutual protection as well. Twenty pairs of sharp eyes are more likely to see an enemy approaching than is a single pair, and it is well for a small bird to keep a sharp lookout at this season, for it is more readily seen by a hawk in a leafless, wintry wood than if it were within a shady summer forest.

\section{Mutual Protection}

Like all other woodpeckers, Downy's mate lays white eggs. These usually number four or five, and are placed on a soft bed of fine chips at the bottom of a hole, which both parents have helped to dig, usually in the under side of a decayed limb of the tree. Nature is not prone to use her coloring-matter on eggs which, like the woodpeckers', are hid away in dark holes in trees. When the little ones are hatched Downy and his mate are kept very busy for a long time bringing them good things to eat, for the little woodpeckers have great appetites, which seem never to be satisfied.

Downy is not only a very neighborly little fellow in his social relations with other wild birds fortunate enough to make his acquaintance, but he also renders them a very great service in providing many homes which they can use. He and his mate usually dig out a new nest every year, and, as a rule, he makes a new hole for roosting purposes every winter. As a result of this, many unused Downy Woodpecker's nests are scattered

\section{Downy's}

Home

about in all our orchards, groves, and woodlands, like empty houses.

Some little birds like the protection afforded by a hollow in a tree, when in spring they get ready to build their nests, and these old abandoned Downy nests are just exactly what they are looking for. I remember finding a nest of one of these little woodpeckers in a small dead birch-stump standing near a brook by the edge of a pasture. The nest was only about five feet from the ground, and although many cattle passed that way each day, and the farmer's house-cat sometimes wandered along the stream, the little white eggs were hatched and the young reared in safety. A year later I chanced again to pass that way. Great was my delight to find that, although the Downies had moved on to another place, their old home contained six as wide-awake little birds as anyone could wish to meet with on a bright spring morning. Scarcely had I made the discovery when their mother appeared, and lo! it was our dainty friend the Chickadee. She and her mate had filled the hole half full of various kinds of soft material, and evidently were as proud of their

\section{New \\ Tenants}

snug home as if they had dug it out with their own weak little bills.

One Sunday morning not long ago I heard a House Wren singing. His heart was full of joy. It was clear that he had won his mate for 
the year, and felt secure in his love-affairs; but I soon found that he was happy about something else also. He had discovered just the place for a nest-at least he appeared to think so-and seemed bent on convincing his ladylove of the fact. Twenty feet in the air, on the under side of a dead limb of a very old and highly esteemed cherry-tree, was a last year's Downy Woodpecker's nest. To this the little singer went repeatedly. He would go in, come to the door and look out, disappear, and then look out again. Of all the places in the neighborhood this, indeed, was the ideal spot for the nest-at least, I believe that was his view of the situation. It is no small matter for a bird to find a safe

Safety

First

nest for its eggs and young; and where can a little mother hide her eggs more securely from the pilfering Blue Jay, or the inquisitive Red-headed Woodpecker, than by placing them deep down in the beautifully secure cavity dug by the strong bill of a Downy Woodpecker?

\section{THE HAIRY WOODPECKER}

Another black-and-white woodpecker very closely resembles the Downy, except that it is a little larger. This bird the books call the Hairy Woodpecker. It is quite true that it differs slightly in appearance from its smaller relative; for example, the outer tail-feathers are white with no marks on them, while the feathers in the Downy's tail are adorned with black spots. On the whole, however, the similarity is very striking. It is usually found in the woods, and is not so much inclined to come about the house as is our friendly, trusting, little Downy, which we all love so much.

\section{Classification and Distribution}

The Downy Woodpecker belongs to the Order Pici, Family Picide, and Genus Dryobates. Its scientific name is Dryobates pubescens. It is resident in all the wooded parts of the United States and Canada, but most of the individuals move somewhat southward in winter from the northern border of the specific range. The Hairy. Woodpecker belongs to the same genus, and is named Dryobates villosus. It has a similar distribution to that of the Downy, but is rather more numerous and hardy in the North. Each of these widely distributed species includes several geographical subspecies.
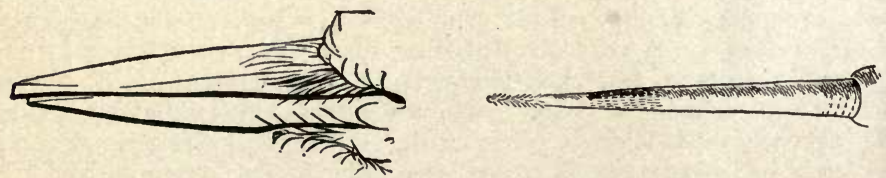

Chisbl-like Brax and Barbrd Tongur of the Downy Woodprickrr

(Both much enlarged)

This and other Educational Leaflets are for sale, at 5 cents each, by the National Association of Audubon Societies, 1974 Broadway, New York City. Lists given on request. 


\title{
THE RUBY-THROATED HUMMINGBIRD
}

\author{
By MABEL OSGOOD WRIGHT
}

\section{The National Association of Audubon Societies Educational Leaflet No. 56}

When the cherry blossoms have falien and the buds in the tumbleddown old apple-orchard are showing pink tips, when the gold-and-black Baltimore Oriole is calling plaintively to his belated lady-love, and the rich song of the unseen Rose-breast falls from the tree-tops, with a whirr and a flash a jewel set in a bit of iridescent metal-work slants across the garden, and we say with bated breath "The Hummingbird has come."

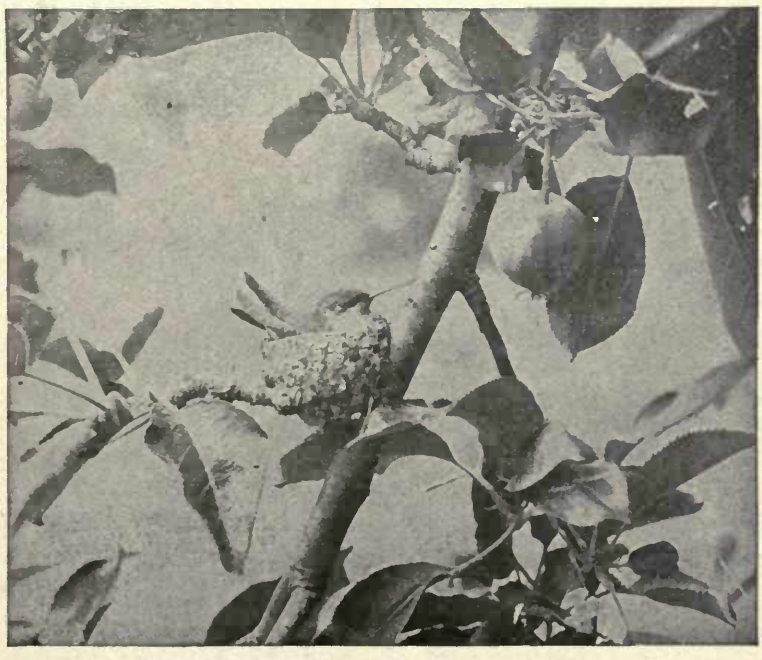

A HUMMINGBIRD'S DOWNY CRADLE

In this case the has a very definite meaning; for in the length and breadth of the country that lies between the Mississippi and the Atlantic, and between Florida and Labrador, there is but one species of hummingbird-that of the Ruby-throat. (The twilight-flying creature so often mistaken for a Hummingbird is, in truth, a hawk-moth.)

When a pair of Hummers first make up their minds to share your garden you will have many chances to watch them before nest-building makes them more elusive. The Hummingbird has the reputation of being 
constantly on the wing; but in reality it is only so while it is collecting food, either the honey from flowers or the small aphis with which it feeds its young, and it spends quite as much time in perching as any other bird. Dead twigs of hemlock or Norway spruce make favorite perches here in my New England garden, and it often seems as if the dainty little thing chose the twigs with conscious regard to the color-protection of his surroundings, when, lo! he is off again, and this times perches in the open on a taut wire, where the light plays on every ruby feather of his gorget, making him conspicuous out of all proportion to his size.

While he rests thus, preening first one wing and then the other, it is a fine chance to study the bird in detail-the upper parts feathered in glistening green, with metallic tints of purple and blue upon wings and tail, and the wonderful ruby throat, separated from

The Least of Birds the dull, gray-green breast by a line of light. From the end of his needle-like bill to the tail-tip he meas-

ures a trifle under three and one-fourth inches, while the wings that make the resonant hum, suggesting the motive power of a machine rather than of a bird, measure only about one and a half inches on each side of the body. Truly this is our "least" bird.

So slim and compact is the Hummingbird that, seen at the usual distance, its plumage has more the appearance of metal-work than the shaft and down of feathers. Its voice also has the sharp squeak of metallic contact, and is utterly unlike the usual bird note. I have heard precisely the same tone from a mouse. But, at close range, all these qualities are transformed. This is a case when a bird in the hand gave me a different idea of that same bird in the bush, forevermore.

Let it be distinctly understood, however, that the coming within range of my touch was by way of succor, and not by way of capture. Many times as the same thing has happened, the first is the best remembered, like many other first times, from the combination of surprise and novelty.

It was at the beginning of rose time. The long-tubed honeysuckles on the back porch brought the Hummingbirds in close range with the dining-room window, and, apparently fearless, they came to and fro during all the daylight hours, sometimes conversing in amicable squeaks, and then

\section{Tenants of a}

Honeysuckle again waging a warfare of evidently angry words and beak-thrusts, even though the pair were mates, one with the ruby throat and the female without, after the family custom.

The lower part of the large window was screened by wire netting; the upper sash, with its diamond panes backed by the partly darkened room, made a series of mirrors, in which the male bird presently spied his own reflection. Could a high-spirited cavalier allow a rival not only to be in the same garden but to be hovering above the very honeysuckle with Mrs. Ruby! Forward and back went Sir Ruby, fencing with the reflection first in one pane and then another, squeaking shrilly, and gradually coming sc close that he struck the pane recklessly Then came a slip and a des- 


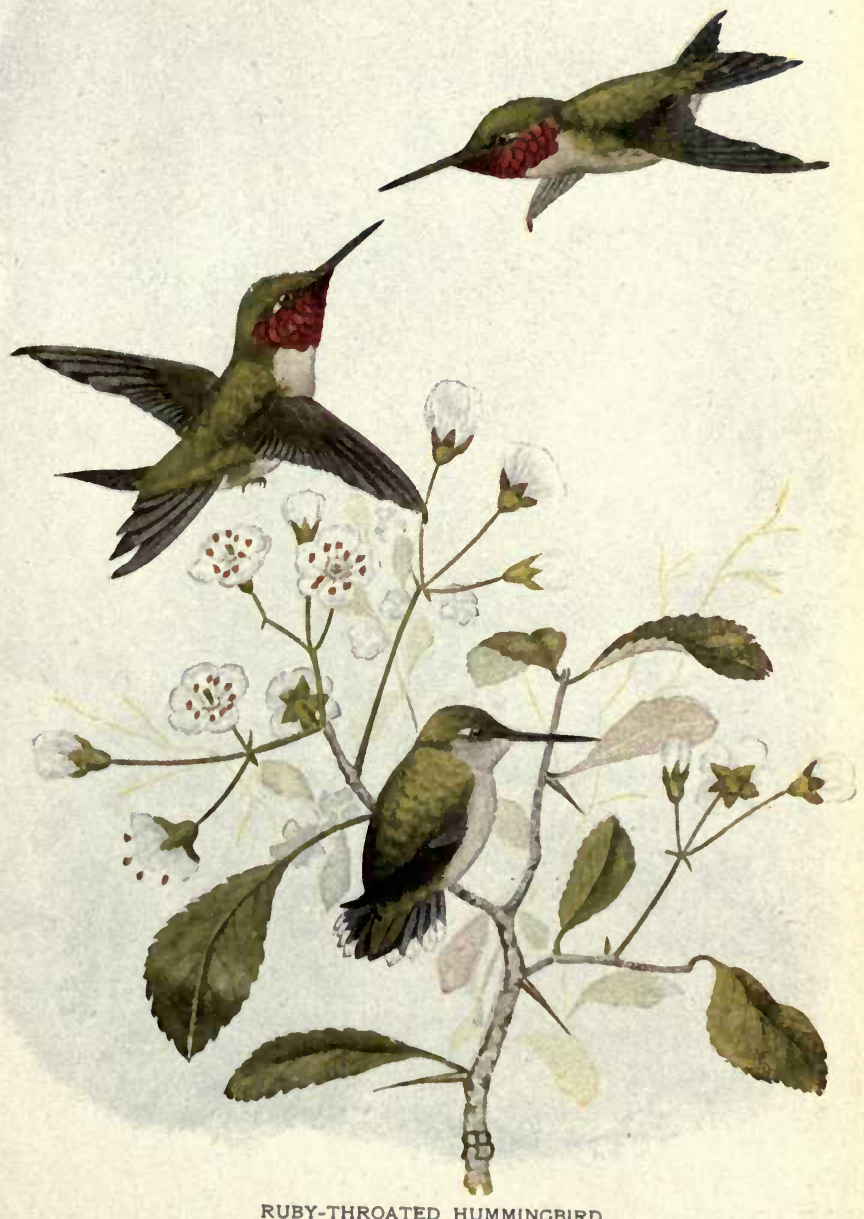

RUBY-THROATED HUMMINGBIRD

Order-MACrochiRzS

Genus-ARChILOCHUS

Family-TrochiLide

Species-COLUBRIS

National Assoclation of Audubon Societies 


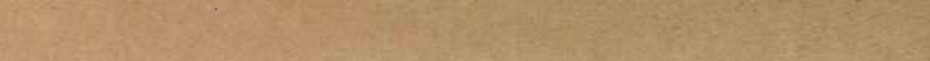

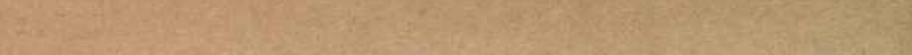
W.

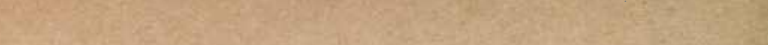

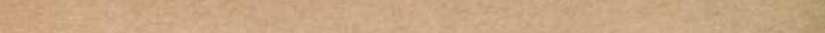

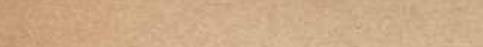

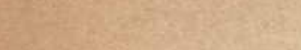

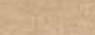

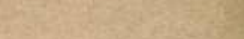

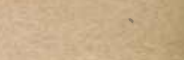

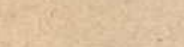

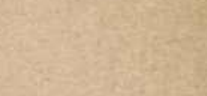

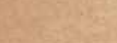

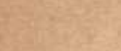

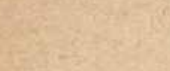

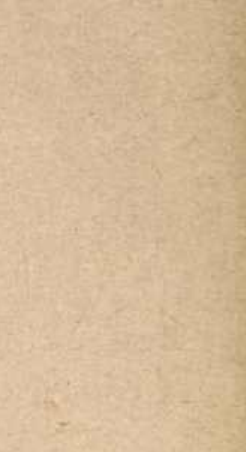

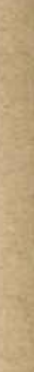
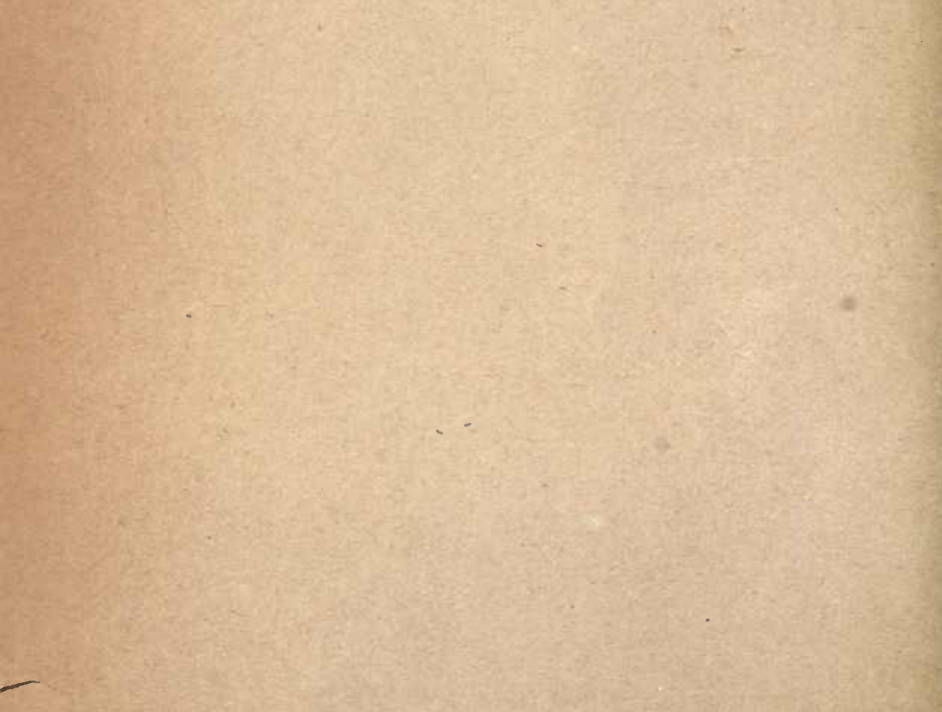

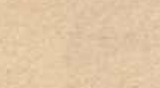<smiles>C1CCC2CCCC2C1</smiles>
2013

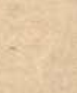

28

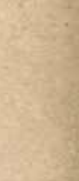

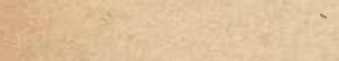

$3 x^{3}-1$

(2) 1957

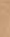

$\cos ^{2}+x^{2}$

$=3$

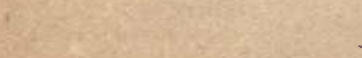

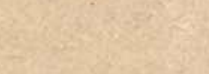


perate thrust, when flying too low, the bird was caught by the beak in the firm meshes of the wire screen, where, after a single effort, he hung quite stunned by the shock.

Going outside, after hesitating a moment,- - so frail and intangible a thing it seemed to touch, I gently released the bill and laid the little body, now inert, with limp neck, in my palm. The tiny claws were closed like clenched fists; had its neck been broken, was it dead? No, for the eyes were open bright, though they did not see, and one of the things that I learned years ago

Sir Ruby's

Adventure

from that unfailing observer, Dr. Elliott Coues, was that, contrary to other forms of animal life, the eyes of a bird always shut in death.

As I closed my hand a little, with the natural instinct to brood and comfort the one hurt, I suddenly felt the thump of that mite of a heart, and the head raised a bit and then fell back again, beak parted. Water and a grass-blade to carry the water to the beak, drop by drop, was the next step. The bill closed and the water was swallowed until five drops were consumed,-quite a draught, all things considered. Another minute and the head was raised. I tried to make a perch of my finger, but it was too large by far. Securing a dry twig from the honeysuckle, I wedged it as well as I could with one hand across a berry basket that was on the poirch table, and placed Sir Ruby upon it, setting the basket well into the shade of the vine.

The claws held firmly to the twig, and the bird settled down sleepily, his only motion being to rub his head (eyes now closed) under one halfraised wing. Then I moved back a few feet and waited. Perhaps two minutes passed when, without warning, Sir Ruby, with a single motion, darted from the vine without even touching the basket's edge, and on across the garden, as good as new. What he thought I cannot know, but I shall never forget the wonderful reyelation of the bird world, and reverence for the creative plan complete in so small a frame, that thrilled through me at the beating of that little heart against my palm.

As housebuilders these Hummingbirds are as unique as in their appearance. Whether the site chosen for a nest be high up almost out of sight, or on a slanting branch close at hand, the nest is usually set astride the limb like a saddle on a horse, instead of being supported by a hand-like series of crotches. An unused nest that I have now before me shows very perfectly the materials from which it was made. Next to the maple branch, less than half an inch thick, is a layer of the soft scales that fall on

Beauty of the Nest the opening of spruce-buds; the body of the nest is of fern-wool, mixed with the down of some composite smaller than the ordinary dandelion. The outside is shingled with cedar-tree moss, as well as a few of the dark scales of spruce-bark.

In this nest, the edge is quite loose and fluffy, and the structure itself is rather small, being not over an inch above its foundation. In this case, the home was, for some unknown reason, abandoned immediately after 
the eggs were laid; had the birds been hatched, the nest would have given them but poor protection. The condition of this nest is apparently explained by two cases that I have watched in the garden, when, after the young were hatched, the mother bird built up the nest about them as they grew.

The eggs of the Ruby-throat, and of all other kinds of Hummingbirds are only two, and are pure white.

After the nesting season is over the males are seen again about the flowers, though greatly outnumbered by Hummers lacking the ruby throat. This, however, is easily accounted for by the fact that the young of the year, both males and females, are plumed like the mother.

One spectacle in the home life of the Ruby-throat is rather awful until you fully understand the cause, and know that the mother is not trying to choke her children to death. She feeds them by regurgitation: that is, she pumps the food, first softened in her own crop, down the

Feeding

Fledglings

little throats by means of her own beak, which she thrusts into their gaping mouths. Early bird students saw this process the other way about, saying that Hummers, Pigeons, etc., pushed their beak into their parents' crops for food-hence the term "sucking doves."

In the Hummingbird we have a species that makes its appeal through beauty of form and grace of flight, rather than through any economic consideration. Beauty as an excuse for being has, however, long since been accepted as a fact. And yet it was through beauty that, at one time, this elusive little bird was almost doomed to extinction, for it is not so many years ago when a wreath of Hummingbirds upon a festal hat was not a rare sight. Public opinion, in the United States at least, will no longer stand for such senseless waste and barbarity. Of no use for food, a difficult prey for either cat or snake, the Ruby-throat should escape most of the ills that befall our native birds, and continue with us when larger birds grow rare.

Unlike many birds of unique plumage or tropical colors, the Hummingbird family belongs entirely to the New World, and is most numerous in the mountains of South America. Of the five hundred or more known species, only eighteen reach the United States, and but few of these pass far north of our Mexican boundary.

\section{Classification and Distribution}

The Ruby-throat belongs to the Order Macrochires, Suborder Trochili and Family Trochilide. Its scientific name is Archilochus colubris. It is found in summer and breeds throughout the eastern United States from Florida to Manitoba, Quebec and Nova Scotia; and it winters in Mexico and Central America.

This and other Educational Leaflets are for sale, at 5 cents each, by the National Association cf Audubon Societies, 1974 Broadway. New York City. Lists given on request. 


\section{YELLOW-HEADED BLACKBIRD}

By THOMAS S. ROBERTS

The National Association of Audubon Societies Educational Leaflet No. 57

The Yellow-headed Blackbird is preëminently a native of the Great Plains, and, although in some parts of its range it invades regions not strictly prairie, it belongs by right to the vast treeless plains of the interior, and to the sparsely wooded areas immediately adjoining on the east and west. Over all this region it ranges, breeding from the extreme northern part of Mexico in the south to the Saskatchewan Valley.

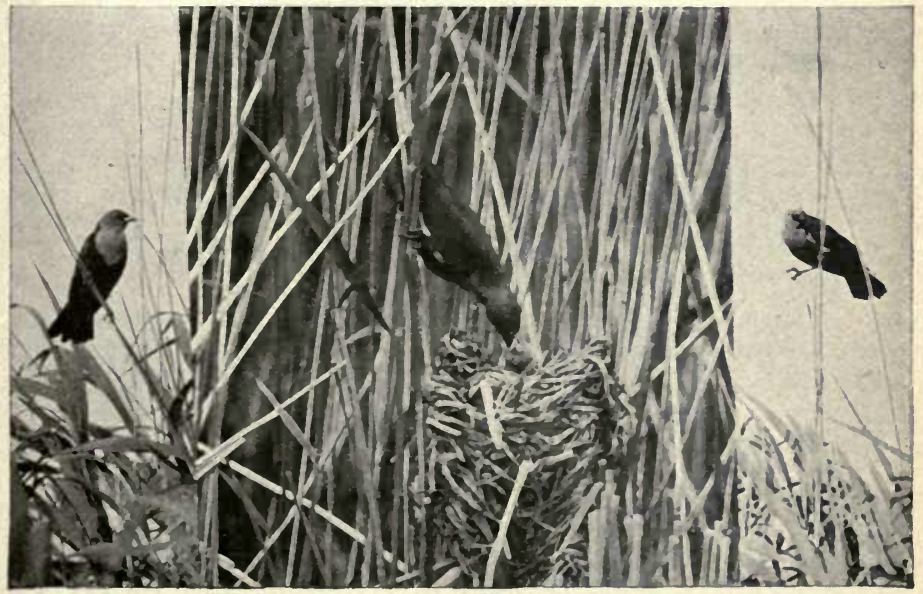

YELLOW.HBADED BLACKBIRDS, AND THEIR NEST

Photographed by Dr. T. S. Roberts, Minneapolis, Minn.

One invariable condition is necessary to induce it to establish a summer residence, and that is an abundant and permanent water-supply, and associated with this must be just the kind of vegetation that is suited to its rather particular tastes. Preference is given usually to a swamp or slough that is very wet and having more or less open water; never meadows or marshes that are simply damp and subject to drying out.

The tule beds of the valleys of the Rockies, the quill-reed brakes of the North, and the flag swamps of the South are alike acceptable. Wherever the Yellowhead breeds it congregates in colonies, and these assemblages are often of vast proportions. It is very loyal to its home- 


\section{Yellow-Headed Blackbird}

site and returns year after year, even when the surroundings undergo great and uncongenial changes, deserting it only with the drying up of the marsh. The Yellowhead is very closely restricted to its special nesting haunts, and as the members of each colony go in the spring directly to their particular rendezvous, and wander but a little

\section{Loyal to}

Home-site way into the surrounding country until after the com-

pletion of the breeding period, they are easily overlooked if their nesting sloughs are not numerous or their homes be not actually invaded.

In the northward movement in spring the vanguard of the Yellowheads that are to breed in Canada reach the international boundary about May 1, the males preceding the females by a few days. In Minnesota, where the writer's entire experience with this bird has been gained, stragglers enter the southern part of the State about the middle of April, but it is not until the very last of that month or early in May that they become numerous.

In this region they breed almost exclusively in the dense growth of quill-reeds (Phragmites) that fills or encircles many of the sloughs and shallow lakes of the prairie and semi-prairie parts of the State. Occasionally spring freshets or other disturbances may drive them to place their nests among bulrushes (Scirpus) in upland sloughs, or more rarely still in willows and bushes adjacent to open water.

\section{A Denizen} of the Reeds

Nest-building is usually begun in central Minnesota about the middle of May and continues until well into June. It seems probable, however, that only one brood is raised in a season, the great variation in the nesting-time being explainable by the depredations of various small animals, which devour the eggs and young, and by severe elemental disturbances.

The examination of many hundreds of nests over a long period of time and a detailed study of a single colony* throughout the entire breeding season furnish the data for the following summary of the chief features of the nesting of the Yellowhead:

The female builds the nest and incubates the eggs without any assistance by the male.

The male assists in the care of the young, but only to a limited extent and chiefly after they leave the nest.

The body of the nest is constructed of wet material collected from the water near by. This is woven about the stems

\section{Structure} of the Nest of the reeds, two or three feet above the water, and its drying and contracting fixes the nest securely in position, as is well shown in the illustration on page 225 .

The lining consists of pieces of broad, dry reed-leaves, and often the rim of the nest is finished with the fine branches of the plume-like fruiting-tops of the reeds, forming a sort of canopy over the somewhat constricted entrance.

\footnotetext{
* For fuller details, see The Auk,.xxvi, 1909, pp. 371-389, 10 plates, 24 photographs.
} 

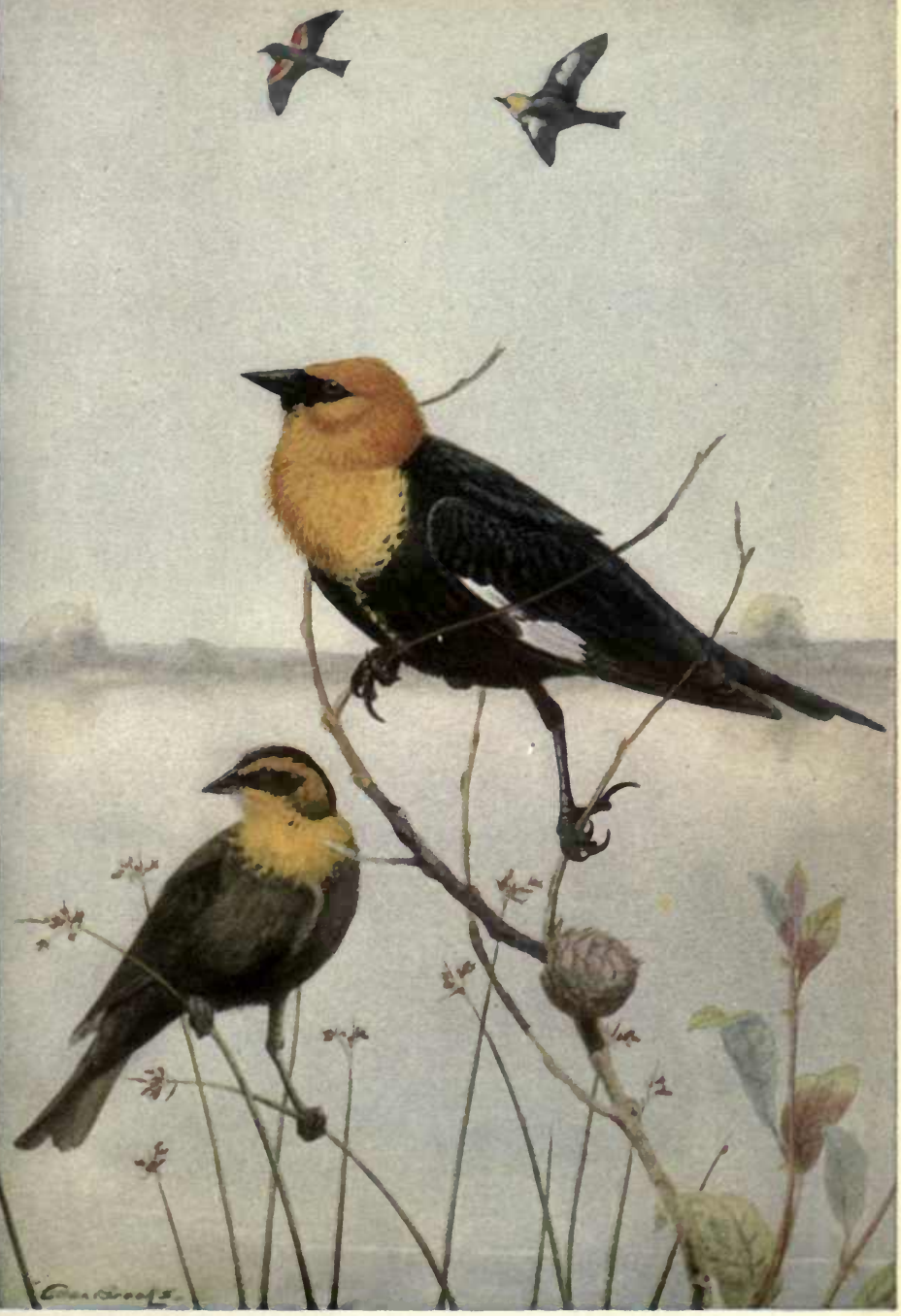

YELLOW-HEADED BLACKBIRD

Ordet-Passeres

Family-iCTERIDE

Genus-Xanthocephalus

Species-Xanthockphalus

National Association of Audubon Societies

Educational Leaflet No. 57 



\section{Yellow-Headed. Blackbird}

The typical finished nest is a firm, inverted, cone-shaped, basket-like affair, suspended among the rigid stems of last year's reeds, only exceptionally among new growth. The height is usually eight to ten inches.

A skillful, industrious bird will build one of these large, beautifully woven and lined nests all complete in two to four days. When it is considered that a single bird has not only to collect but skillfully to manipulate all this large mass of material, it is surprising to see these bulky nests spring up almost over night.

The eggs in a set are three to five, usually four. They are laid one each day, the first egg one to five days after the completion of the nest, depending apparently upon the time it takes the nest to dry out. All the eggs of a set are alike in color and shape, but there is considerable variation in different sets. The outline varies from almost elliptical to a pronounced

\section{Handsome}

Eggs

ovate. The measurements vary from 1.12 inches to .94 inches in length by .76 to .64 of an inch in breadth. The shell is smooth and glossy. The ground-color of the four eggs varies from a soiled greyish white in some sets to a pale olive-white in others, and in rare instances has a faint pink-lilac hue. When these tints correspond, as is usually the case, to similar shades in the markings, there result eggs of a general dull gray, olive, or pink-lilac hue. The markings vary from a fine close speckling, almost uniform over the entire egg, to large blotches scattered at the smaller end and becoming confluent at the larger end. Most of the eggs present very fine and irregular tracings and spots of black or dark brown about the larger end, suggesting the more pronounced zigzags on the eggs of other Blackbirds and Orioles.

The usual period of incubation is ten days.

The young remain in the nest about twelve days, when they begin a precarious life in the swaying reed-tops, where they are cared for for some days by both parents. The curiously variegated, generally buffytoned, plumage of the young birds blends well with their surroundings at this time; and, as they are indisposed to move, it quite effectively conceals them.

The nesting season over, old and young leave the sloughs and marshes and, congregating in straggling flocks, sometimes accompanied by Redwings and Grackles, wander over the upland for a short time before departing for the South. They rarely assemble in the

North in the large compact flocks so characteristic of the Redwing and the Rusty. Their southward move-

\section{Migration}

ment begins early, and they have largely left the northern part of their range by the first of September. Stragglers, however, may occasionally be found even until snowfall. Throughout their winter range in the southern United States they roam about in flocks, feeding familiarly about cattle-ranches, farms, and the outskirts of towns and villages, leading a sort of Cowbird existence.

The song of the male Yellowhead, if song it may be called, is a most remarkable, unmusical and unbirdlike effort. At a time of the year when 
most other birds are singing finished nuptial songs, however humble, this fine fellow, perched aloft on a cluster of swaying reed-stems, is straining every nerve in an attempt that results, after a few harsh preliminary, but fairly promising notes, in a seemingly painful choking spell that terminates in a long-drawn rasping squeal that is nothing short of harrowing. It has always seemed as though some day a Yellowhead would be found who could sing the song that they are all trying so hard to render, but thus far not a single note of the dreadful discord has been improved upon, and it always ends in the same disappointing failure.

The rasping sounds are accompanied by a most intense bodily effort,

A Poor

Sinf̧er

as is evidenced by the widely spread tail, swollen throat, upturned head and twisted neck. Even the ordinary call-note is a hoarse rattling croak that suggests a chronic sore throat. The voice of the female is less harsh, and I have never heard it utter the long squeal of the male.

As an economic factor, the Yellow-headed Blackbird plays about the same role as the Redwing; but the fact that it is in the aggregate much less numerous and much more restricted in its general range renders it of less importance than the latter enormously abundant and widely distributed species.

But with the coming of spring and the reoccupation of the northern portions of their range, they congregate at their nesting-haunts and for a time supplement their insect and waste-seed diet by extensive stealings from the various grains being planted by the neighboring farmers. Wheat, oats, flax, corn, and, in fact everything, receives a share of their attention at this time. Sprouting corn is pulled up by the roots in order to get at the grain below, and in fields near the sloughs it is only by replanting the despoiled hills and covering with manure that a crop can be started at all.

It is at this season that the Yellowhead and its associates-the Redwing and Grackle-come in for their first bitter denunciation by the plundered farmer. After the crops are well started, the Yellowhead once more returns to a diet that is more beneficial than

\section{Spring}

Mischiet injurious. During the "breaking" season they, in company with a troop made up of Franklin's Gulls, Black Terns, Grackles and Cowbirds, may be found following every plow and greedily devouring the many angleworms and insects turned out. I have known them to consume large numbers of the white grub of the cockchafer in this way. Grasshoppers they eat at this time as well as all through the season, and this insect forms a large part of the food of the young.

\section{Classification and Distribution}

The Yellow-headed Blackbird belongs to the Order Passeres, and Family Corvida. Its scientific name is Xanthocephalus xanthocephalus. It ranges in summer from the upper Mississipoi Valley on the east. and the Saskatchewan Valley on the north to the central plains, southern Rockv Mountains and southern California. Its winters are spent in northern and central Mexico.

This and other Educational I eaflets are for sale, at 5 cents each. by the National Association of Audubon Societies, 1974 Broadway, New York City. Lists given on request. 


\section{THE CALIFORNIA QUAIL}

By JOSEPH MAILLIARD

\section{The National Association of Audubon Societies Educational Leaflet No. 58}

The California Quail-including under this name the two subspecies we have in the State-is one of the most interesting and most commonly met with of the birds of California.

Along the more rainy and damper coast-belt, the Quail is of a darker hue and larger form; while in the dryer interior and in the deserts, where the sun shines nearly every day in the year, and often shines intensely, it is somewhat

\section{Two}

Forms

smaller and paler. The darker bird is called the California Quail, and the paler one the Valley Quail.

The range of one or the other of these 'races' or 'subspecies' extends almost throughout the State except at the higher elevations. From the lesser mountains of northern California to the waste areas of the southern deserts, from the wave-washed cliffs of the western seacoast to the foothills of the snow-capped Sierras, it is everywhere present in varying abundance. It is to be seen and heard amid the rocks and cactus of the Colorado Desert, where it thrives in friendly contest with its cousin, Gambel's Quail : among the vast sagebrush areas of central and southern California; on the plains of the great valleys where green stretches of alfalfa are a striking contrast to the fields of golden grain waving in the summer breeze; in the hills covered with live oak and chaparral near the coast; and among the foothills of the Sierra Nevada, up to a height of three or four thousand feet. In fact, wherever there is a little water to drink, a sheltered place to roost at night, and grain or grass-seeds for food, one is likely to meet this species-and it is a bird worth meeting!

Always sleek and well-groomed except when molting, with an air of sedate, but active, respectability, quick as a flash when danger threatens, the male seems ever proud of his richer coloring and gracefully curved head-plumes,

Proud of his Plumes as he marches about or runs swiftly along in search of food, while his consort follows meekly in her more quiet garb.

The Quail has several very distinct and differently used notes and calls. The call most commonly noticed is more like a rooster's crow than a song, and is easily imitated by a child, a woman, or even by a man, if he has a good falsetto, and sounds something like $k a-k a-k a o$, which is interpreted by various human beings to suit their fancy. Some declare that Mr. Quail says "Put that down!," others that he distinctly means "Cut it out!," while the hunters know that he says "You go'way!" But 
this call is given only when le feels happy. There is a variation to it, given with the same notes, but with a very different accent, that sounds like $k u-k u-k u$ ! with the accent strongly on the second note, and the last note faint. This means some sort of warning to the flock. It is not the real danger-signal, but is a notice from the lookouts to be on guard; and after a flock has been scattered it is used as a gathering signal, separated birds calling to each other from a distance.

The real danger-signal is very different, and-sounds like $d s t$-dst-dst, (drawing in the air or breath). Both male and female

Danger

Signals flock runs to cover. Twittering may be heard either after a flock has been scattered and is collecting, or in the early mornings when the birds come down from the night's roost, and are getting together and deciding where they will have their breakfast. This is a subdued but very pleasant sound, and seems to be in the way of friendly greeting.

In early spring these Quails are to be found mostly in pairs. Later, when the nesting season begins, the male takes his stand upon bush, rock, stump, post, or any good vantage point, and gives voice to a single call, repeated at frequent intervals and loud enough to be heard quite a distance. Whether this note is one of encouragement to his sitting spouse, or whether given to show how good it feels to be alive in the springtime, we cannot know ; but in our California spring it is a most characteristic sound.

A Quail's nest is usually but a mere hollow in the ground, perhaps with a little dried grass or a very few feathers as lining, with advantage taken of a stone, shrub, or tuft of grass to help conceal it. It is seldom found, except when the startled mother flies up from almost under one's feet.

The number of eggs varies greatly, and sometimes the little hollow almost overflows with them. As high as thirty-one have been found in

Nest and Eggs a nest by the writer, but the usual number is from fifteen to twenty. It seems as if more than one bird must be laying, in the case of the very large sets, and it is often easy to separate a set into two or three distinct types of marking and shades.

The ground-color of the eggs is creamy white, while the markings are irregular spots and blotches of a color from old gold to brown. Some eggs are heavily marked, while others are nearly white. It is a very singular thing that if the eggs are disturbed by a person-even if only touched by one finger-the nest is almost always deserted. One may step within a few inches of a nest and frighten the bird away, not only once but several times, and still the bird will come back. But disturb the eggs ever so slightly-pick up an egg and put it back as near as possible just as it was before-and the next time you go to look at the nest the eggs are cold, the nest deserted, and possibly robbed by some 


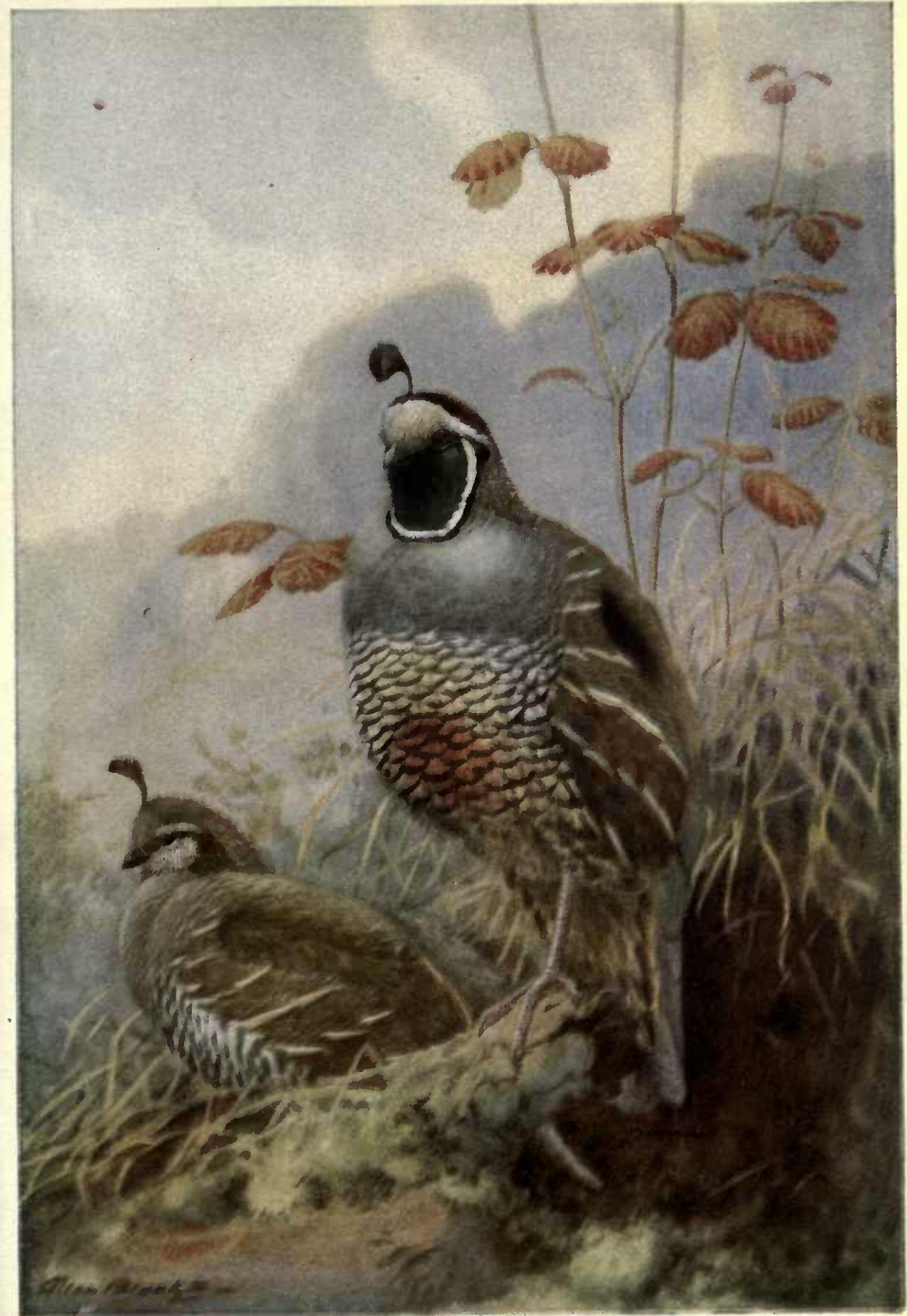

CALIFORNIA PARTRIDGE

Order-Galline

GenUS-LOPHORTYX
Family-ODONTOPHORIDE

Species-Californica

National Association of Audubon Societies 

jay, snake, or four-footed creature. This is unfortunate, because Quails often select places for their nests near houses or on cultivated lands.

Very rarely one will find a Quail's nest in which the eggs are just hatching, and the young have such an instinct for hiding that they will actually run to cover with half of the egg-shell still clinging to their backs! The tiny youngsters give a little weak-voiced peep or two, and then all is quiet. They would be stepped on and crushed before they would make their hiding-place known! They run about in a most lively way by the time they are two or three days old, and are often to be seen along the less-frequented roads in summer time.

Like chickens, the Quail love to scratch in the dust, and a dusty road, without too many passers-by, has a strong attraction for them. It is a pretty sight to see the old ones leading the broods in such places, stopping to pick up seeds here and there, with their head-plumes bobbing each time they give a peck at a seed, wallowing in the dust now and again, but ever

Dust

Baths

with a watchful eye for danger; while the youngsters run hither and thither, now scattering a little, then closing up again at a warning from the old ones, covering the dust with the tracks of their little feet, and gradually working their way along the road.

Each flock of Quails has its own special domain, and never wanders far away; and in the summer, before the birds are made wild by the opening of the shooting-season, any one passing often over a road early in the morning, or late in the afternoon, may see the same flock again and again, and watch the youngsters grow. While the Quails scatter out in pairs in the nesting season, and keep their broods separate for a little time when still very young, they soon begin to band together; and where they are plentiful the bands become larger and larger as fall approaches, until, in places, they number hundreds in a flock. But in the more thickly settled country they are sadly diminishing, and one may find only a small band of ten or twelve living near a spring where he used to see a hundred.

While the California Quail is very wary in some ways, it often takes up its abode in the vicinity of houses, and even in cities where there are gardens with shrubbery. Unlike the eastern Quail-the Bobwhite-which spends the night on the ground, the California Quails invariably roost in bushes or trees, and sometimes take possession of a garden, and even walk around the porches of houses where protected from marauders. 'But let anyone try

Familiar Ways

to get near them, and off they go, with their peculiar whirring of the wings. This bird can be more or less domesticated by keeping it in an enclosed place, and sometimes it nests in confinement, but it seldom gets really tame.

In some parts of the State, especially in the southern interior, these Quails will run long distances, instead of flying, when disturbed by the hunter - often as far as half a mile. In the more wooded parts they fly into trees, where they manage to hide themselves in such a manner 
that it is almost impossible to see them; while, if you do happen to get your eye on one, he seems to know it on the instant, and is off like a shot. Their power of concealment is remarkable under any circumstances. Even on the barest sort of ground, where perhaps a dry season has allowed of but little growth of grass, and that little has been gnawed off by the hungry cattle until only a few shreds of fine straw lie on the ground, the Quail will take advantage of a little hollow no bigger than the palm of one's hand, or a stick, bit of stone, anything at all, and become invisible.

The California Quail does not eat many harmful insects, but is of much benefit as a destroyer of weed-seeds. It is fond

\section{Eating \\ Weed-Seeds} of grain, and may scratch up and eat a little in a sown grainfield, before and after the grain has sprouted; but even then it is eating a lot of weed-seeds as well, and does much good in other places and at other times of year.

When present in large numbers, it will eat a lot of grain that has fallen on the ground after harvest, and which would be picked up by hogs or sheep in the usual method of farming, but it does very little damage to the standing grain.

The principal complaint against the Quail is from the vineyard men. The bird seems to delight in vineyards, and often large flocks will make their abode therein, possibly as much for the cover and protection from hawks as for the fruit itself. Whichever it is, many grapes are pecked as they ripen, when the "yellow-jackets" (a kind of wasp) begin work at the opening made by the Quail, and soon leave nothing but the empty skin. Only a few may be pecked in a bunch, but it injures the value and weight of it. However, it is more likely that other birds do a good deal of damage for which the poor Quail is blamed.

\section{Classification and Distribution}

The California or Mountain Quail belongs to the Order Gallina, and to the Family Odontophorida. Its scientific name is Lophortyx californica californica. A subspecies, the Valley Quail, is named $L$. $c$. vallicola. It inhabits the Pacific Coast region between Oregon and the southern part of California.

This and other Educational Leaflets are for Sale, at 5 cents each, by the National Association of Audubon Societies, 1974 Broadway, New York City. Lists given on request. 


\section{THE NUTHATCHES}

By FRANCIS H. ALLEN

\section{The National Association of Audubon Societies}

Educational Leaflet No. 59

There is something eerie about these little birds, with their quaint form and queer ways; but if a bird wants to hop down a tree-trunk as well as up it, he must dispense with the use of his tail as a support and depend entirely upon his two feet, and to balance himself properly not only must the feet be strong, the hind toe long, and the claws sharp and hooked, but the whole bird must be made short and compact.

Now, the Nuthatch needs a fairly long bill to poke deeply into the crevices of the bark for his insect-food, and a fairly stout one to pry off the chips and dig it out, so that the economy in length must be in his neck and his tail. And here we have our bird, as Nature has made him, and as Mr. Brasher has drawn him-a short, squat figure, with a tail only long enough to balance his beak and steady him in flight, but with capable feet. Form fitted to
Service

But why should a bird wish to travel downwards on a tree-trunk? To get his daily bread in the way that seems most natural and easy to him. Evidently the Nuthatch is filling a gap in nature. He would not have adopted so unusual a method of feeding if it had not stood him in good stead. I suspect that by approaching his prey from above he detects insects and insect-eggs in the crevices of the bark which would be hidden from another point of view. The woodpeckers and the creepers can take care of the rest. Of course these other birds get something of a downward view as they bend their heads forward, but the Nuthatch has the advantage of seeing, before he gets to them, some insects which even a Brown Creeper's gentle approach would scare into closer hiding in their holes and crannies.

To most of us who live in the Northern States the Nuthatch is

THE WHITE-BREASTED NUTHATCH.

We know him best as a welcome pensioner on our winter boúnty and an inclustrious gleaner of insect-food from the trunks and branches of the leafless trees in autumn, winter, and early spring. We love his familiar unmusical notes, which seem so friendly to tis, perhaps because they really express an unusual appreciation of the companionship of his kind. The most striking of these is the one commonly interpreted as quank. To my ear, however, though nasal, it has nothing of the $n k$ in it, while it has a distinct $r$-like quaver. It may be rendered as pr-r-ááp, sounded through the nose. Another note, reserved for closer com- 
panionship, or soliloquy, is like the syllable tiit, pronounced as in German, very short and slight, and repeated irregularly and indefinitely.

The home life of the Nuthatch in summer is not so well known to most of us as his winter ways, because he is rather retiring during the nesting-season, preferring woods with a growth of large oaks or other hardwood trees to the neighborhood of human habitations. The spring song, however, begins before the bird leaves his winter haunts. It resembles the familiar laugh of the Flicker, but is not

Spring

Song nearly so loud, and is more pleasing. It consists of eight or ten repetitions of a single syllable-what, or $h a-h a-h a-h a$, etc.-more liquid in quality than the call-note.

The nest, which is placed in a hole in a tree, or in some similar situation, is prepared in March or April, according to locality. The hole is usually a natural one in a decayed part of a living tree, or in a dead tree or stub. It is enlarged and shaped by the birds, both sexes working together. The lining is made of such materials as feathers, hair, fur, bark-strips, and leaves, loosely thrown together. From six to nine eggs are laid, white or cream-white, thickly and uniformly spotted with reddish brown and lavender.

The male White-breasted Nuthatch is a particularly devoted husband. He carries food to his sitting mate, calling her to the mouth of the nesting-hole to receive it. At other times of the year, too, the pair keep together faithfully, hunting their food in close proximity to each other, and keeping up a continuous conversation of pr-r-ááps and tüt-tiits.

\section{An Insect- catcher}

The Nuthatch has a stout bill and a strong gizzard; and when he finds his insect-food scarce he ekes out his subsistence with seeds and nuts.

The habit of "hatching," or hacking, chestnuts, beeclnuts, acorns and similar soft-shelled nuts, has given his kind its name of Nuthatch. The nut is wedged into a crevice that will hold it firm, while the bird hammers it open. Another interesting habit of this, and the related species, is that of hiding nuts in cracks and crevices in the bark of trees, holes in fence-posts and like places, presumably for the purpose of keeping them for future use. This vegetable food, however, seems to form a small part of the White-breasted Nuthatch's diet. Edward H. Forbush regards this bird as a valuable aid to the orchardist and forester. It feeds largely on beetles, including the boring beetles, on scale-insects, and on many hibernating eggs, larvæ, and pupæ of insects. Ants and spiders, and canker-worms, forest caterpillars, and plant-lice are also

Destroying Gipsy-moths eaten. One pair in Brookline, Massachusetts, was seen to search beneath the burlap bands placed about shade-trees to guard against the ascent of caterpillars of the gipsy-moth, which the birds fed to their young in large numbers.

I have this minute been watching a pair of these Nuthatches feeding in my apple-trees and pear-trees. They traveled restlessly up and down and around the trunk and branches, never proceeding very far in a straight line, and stopping at every few hops to dig out a grub, hammer- 


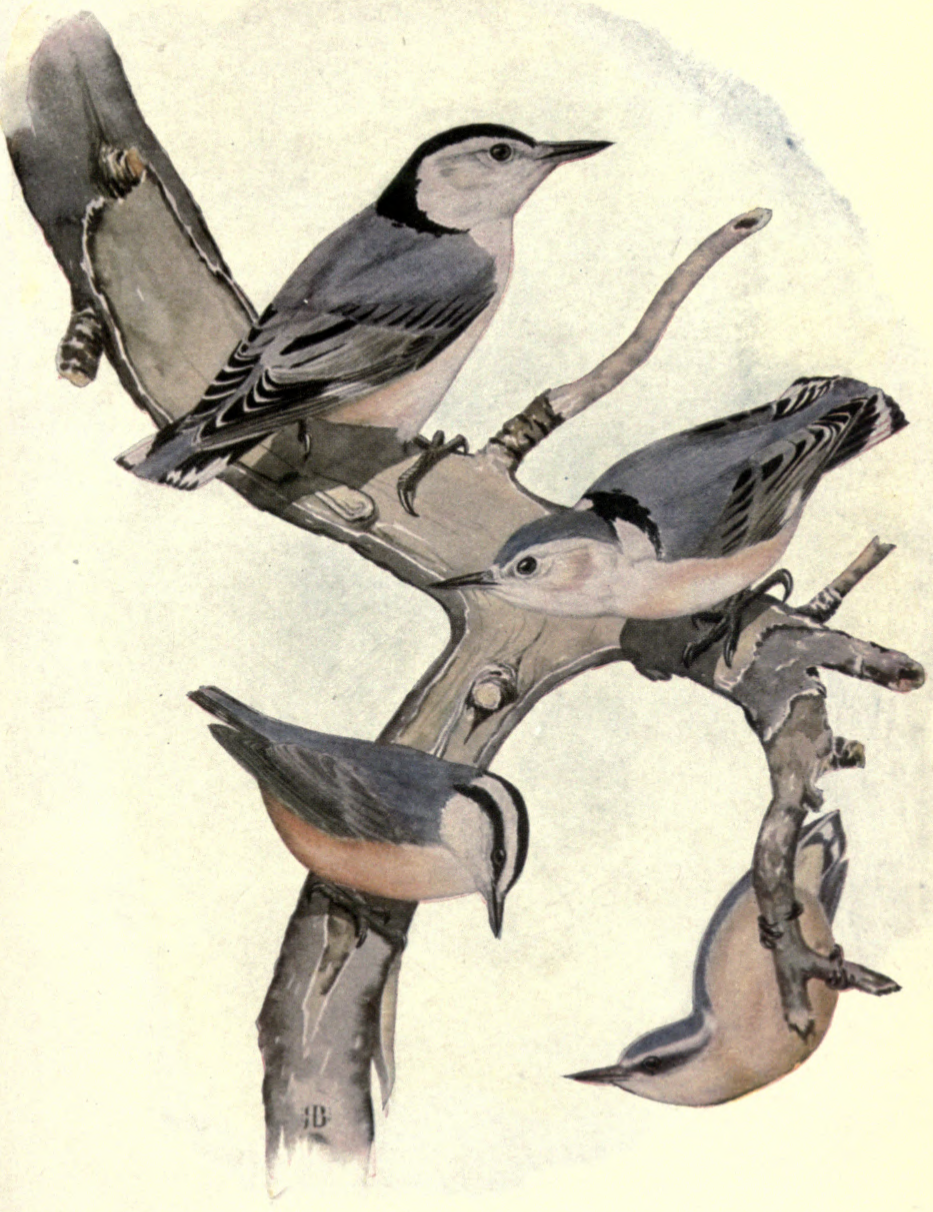

White-BREASTED NUTHATCH, Upper Figures, Male and Female RED-BREASTED NUTHATCH, LOwer Figures, Male and Femalz
Order-PAsSERES
Genus-SitTA
Family-SitTide
Species-Carolinensis and Canadensis

National Association of Audubon Societies 



\section{The Nuthatches}

ing like a Woodpecker and making the chips of bark fly. When in a precarious position on the under side of a limb the bird held itself by keeping its legs stretched far apart and its claws firmly anchored to the rough bark, the large hooked hind claw apparently doing most of the work. The birds kept up a lively conversation as they worked, and now and then looked off while clinging head downward, assuming that quaint posture so characteristic of their kind; finally they flew away with a whir of wings and an undulating flight, and I returned to my desk by the window.

Flight and Kange

Although the breeding-range of the White-breasted Nuthatch is virtually coincident with its entire range, it seems to be somewhat migratory in its habits, and probably breeds most numerously in the northern part, and does not winter in any numbers much farther north than Massachusetts.

THE RED-BREASTED NUTHATCH

To those who know it the Red-breasted Nuthatch is dear out of all proportion to its size and its musical attainments. It is livelier than its big cousin, and prettier in its markings, and there is something particularly fetching about its quaint little form. It is even less of a songster than the White-breasted species, for prolongations and repetitions of its call-note seem to be all it has that can pass for a song. This call-note can be rendered as ááp. It is nasal, like that of the White-breasted Nuthatch, but much higher in pitch, more drawling, and lacks the $r$. It has been happily likened to the sound of a tiny trumpet or tin horn.

The habits of the Red-breasted Nuthatch are so like those of the White-breasted that much that I have said about that species is applicable to this. The most striking difference is in the favorite haunts of the two birds, the Red-breasted preferring the coniferous woods, or mixed woods that contain a large proportion of evergreens. In those winters when they are found in southern New England they come freely to the neighborhood of man's dwellings and feed familiarly on the supplies provided for the winter birds, but even there they show their partiality for coniferous trees. They are particularly fond of the seeds of pines and spruces, so that they are much more vegetarian than their White-breasted cousins. They have the same habit of hiding their savings in cracks and crevices.

\section{Habits of the Redbreast}

This Nuthatch does eat insect-food, however, and may often be seen hopping up and down the trunks and over the branches of trees. It feeds among the small branches and twigs more than its cousin; and, according to W. B. Barrows, in his "Michigan Bird Life," is often seen investigating tufts of dead leaves of deciduous trees. If this latter habit is a well-developed one, the bird should be useful in destroying nests of the brown-tail moth.

The Red-breasted Nuthatch excavates its nesting-hole usually in dead or partly decayed trees. O. W. Knight, in his book, Birds of Maine, says that a balsam-fir stub is the favorite tree for the purpose; 
one with punky wood, but the bark still clinging. In other cases poplar trees and birches are chosen, but the locality is usually in spruce woods, or at least in woods where conifers abound. Both sexes work at the excavation. The hole is usually lined with finely shredded bark or woodfibers, and perhaps with soft grasses or feathers. The eggs number four to six or seven, are white or cream-white, and speckled with reddish-

Pitch-ringed Nest-hole

brown and lavender. The most remarkable and characteristic thing about the nest is that the entrancehole is invariably surrounded by a ring of pitch, brought from a neighboring spruce, pine, or balsam fir.

It breeds in the Canadian fauna, and its migrations are dependent largely on the cone-crop in the forests about its home. If cones are abundant in the White Mountains, for instance, the Red-breasted Nuthatches of that region remain there for the winter. If, however, the crop is a failure, as not infrequently happens, the birds go southward in late summer and early autumn. When they migrate south they are rather likely to go beyond southern New England.

One interesting habit of this bird, in connection with its migration, is the curious one of dropping down on ships at sea. Birds of many kinds occasionally alight on ships far away from land, but no other, I think, so habitually as the Red-breasted Nuthatch. It may be seen on such occasions traveling in its characteristic fashion up and down the masts and shrouds, and even alighting on the hats and clothing of persons on deck. Red-breasted Nuthatches are also frequently found climbing over the rocks on the seashore, or on islands off-shore. I suspect that these little birds, not accustomed to long flights, on finding themselves far from land, are glad to drop down on anything that promises to give them a foothold and a prospect of rest and food. They show their adaptability by making the best of things wherever they find themselves, and on sea, as on land, they win the hearts of men.

The Brown-headed Nuthatch (Sitta pusilla) is a species of the pine-

regions of the Southern States; is somewhat smaller Nuthatches than the Red-breasted, and has the top of the head brownish-gray, and a whitish patch on the nape.

The Pygmy Nuthatch (Sitta pygmea) is even a trifle smaller than the Brown-headed, and has a grayish-olive crown and buffy-white underparts; its habitat is west of the Rocky Mountains.

\section{Classification and Distribution}

The Nuthatches belong to the Order Passeres, Suborder Oscines, Family Sittida and Genus Sitta. The White-breasted is named Sitta carolinensis. It ranges over all temperate North America, and five geographical races are recognized. The Red-breasted is named Sitta canadensis. Its range in the breeding season is more northerly than that of the White-breasted, and it shows more tendency toward migration. 


\section{THE WILLOW PTARMIGAN}

\section{By JOSEPH GRINNELL}

\section{The National Association of Audubon Societies}

\section{Educational Leaflet No. 60}

The word Ptarmigan is applied to several species and races of grouselike birds comprising the genus Lagopus. The name was chosen appropriately, for lagopus (Latin) signifies "rabbit-foot," and refers to the chief character by which ptarmigans are distinguished fron other members of the grouse family, namely, the heavy clothing of hair-like feathers which envelops the feet. In all but one of the species remarkable changes of plumage take place twice a year, through which there is acquired for the winter season

A Bird of the Snows

a snow-white dress. This, and the fact that ptarmigans live in the far North or on the tops of snowy mountains, gave to these birds their other name, Snow Grouse, used commonly in Alaska.

North America has three distinct species of ptarmigan. One of them, the White-tailed, lives upon the snowy summits of the Rocky Mountains south as far as northern New Mexico. The Rock Ptarmigan inhabits the mountainous country farther north, and, as represented by various subspecies, is found from Greenland across the continent and on nearly every one of the long chain of Aleutian Islands. The third American species, the Willow Ptarmigan, with which the present essay is concerned, is most abundant on that level or rolling arctic prairie-land known as tundra. This tundra extends almost unbrokenly across North America from Labrador to western Alaska, and may be said, in a general way, to occupy the interval between the northern limit of forest-growth and the Arctic Ocean. In western and northern Alaska it is covered with a deep layer of moss and lichens; and here or there in "draws," or shallow valleys, are tracts of dwarfed willows and alders.

Save for black tail-feathers, almost completely concealed when the bird is at rest, and the black of the bill and eyes, the Willow Ptarmigan in winter is pure white. When the white feathers first appear, in the fall, they possess a

A Protective

Dress perceptible, though faint, tinge of pink; but this soon fades out.

The purely white winter dress is believed to make the birds so inconspicuous against the white of the landscape that many times they escape discovery by their enemies, the arctic fox and gyrfalcon, as well as by the human hunter. On a day when the sky is overcast with dense haze, dispersing an intense, even light, the ptarmigans are extremely hard to discern agains the blank whiteness of their surroundings. Even when fresh foot-prints in the snow and occasional cries told of their near vicinity, I 
have often found myself to be within but a few yarls of the birds before they would take flight with a startling whirr of wings and hoarse notes of alarm. Then, as one would alight at some distance, it would seemingly vanish from the sight, frequently defying rediscovery.

On the occasional cloudless day, when the sun shines unobstructedly, even white objects are brought out in sharp relief by their long, dark shadows, cast upon the snow. If approached then, at right angles to the rays from the sun, the ptarmigans may be discerned at the distance of several hundred yards; but they are then shy, for they have a marvelous way of appearing to know whether or not the hunter is actually aware of their exact position.

During the eight months of winter Willow Ptarmigans feed upon the buds and tender terminal twigs of the dwarf alder and

Winter Fare willow and virtually nothing else, save that quartz gravel is regularly gathered from the river-bars, where the wind bares the ground of snow.

The Willow Ptarmigan is by nature gregarious. Especially is this trait exhibited in the autumn months, when in the most northern localities a partial migration is taken a few hundred miles to the south, or into great valleys where more food and better cover are afforded, for the birds show a predilection for the vicinity of brush-patches and tracts of stunted spruce-trees. Frequently they escape from the dash of a falcon by taking refuge in a bush, among whose stems the snow rests lightly, and into which the frightened bird is able to plunge quite out of sight.

In the early spring, long before the thaw commences in earnest, the male ptarmigan begins to change to a rich chestnut-brown color on the head and chest, and a bright red comb develops above each eye. For a time, in April and early May, the males, with their deep brown mantles and white bodies, are very conspicuous. They are then more noisy than at any other season, uttering, at frequent intervals until late dusk, a low, harsh cackle, roughly imitated in the Eskimo Changes
in Plumage name for the Willow Ptarmigan, A-käzé-rh-gäk. The male wears this special courting-plumage until June, when another change, involving the whole body-plumage, leads to a brown-black-and-buff plumage, which is worn until autumn.

The females, meanwhile, change rapidly in early May, about the time the snow begins to disappear, to a mottled-and-barred, black-and-brown coloration. In this "summer protective" plumage the birds of both sexes are as difficult to see against the green, brown and gray of the open tundra, as they were in winter plumage against the white landscape.

All these remarkable changes in appearance are the result of molts, by which feathers of one color fall out and new ones of a different color grow in. In the autumn, exactly the same process leads from the brown and mottled coloring of both old birds and young-of-the-year to the pure white of winter dress. But while in the soring molt the feathers of the head, neck, and back are the first to be replaced, in the fall these are the 


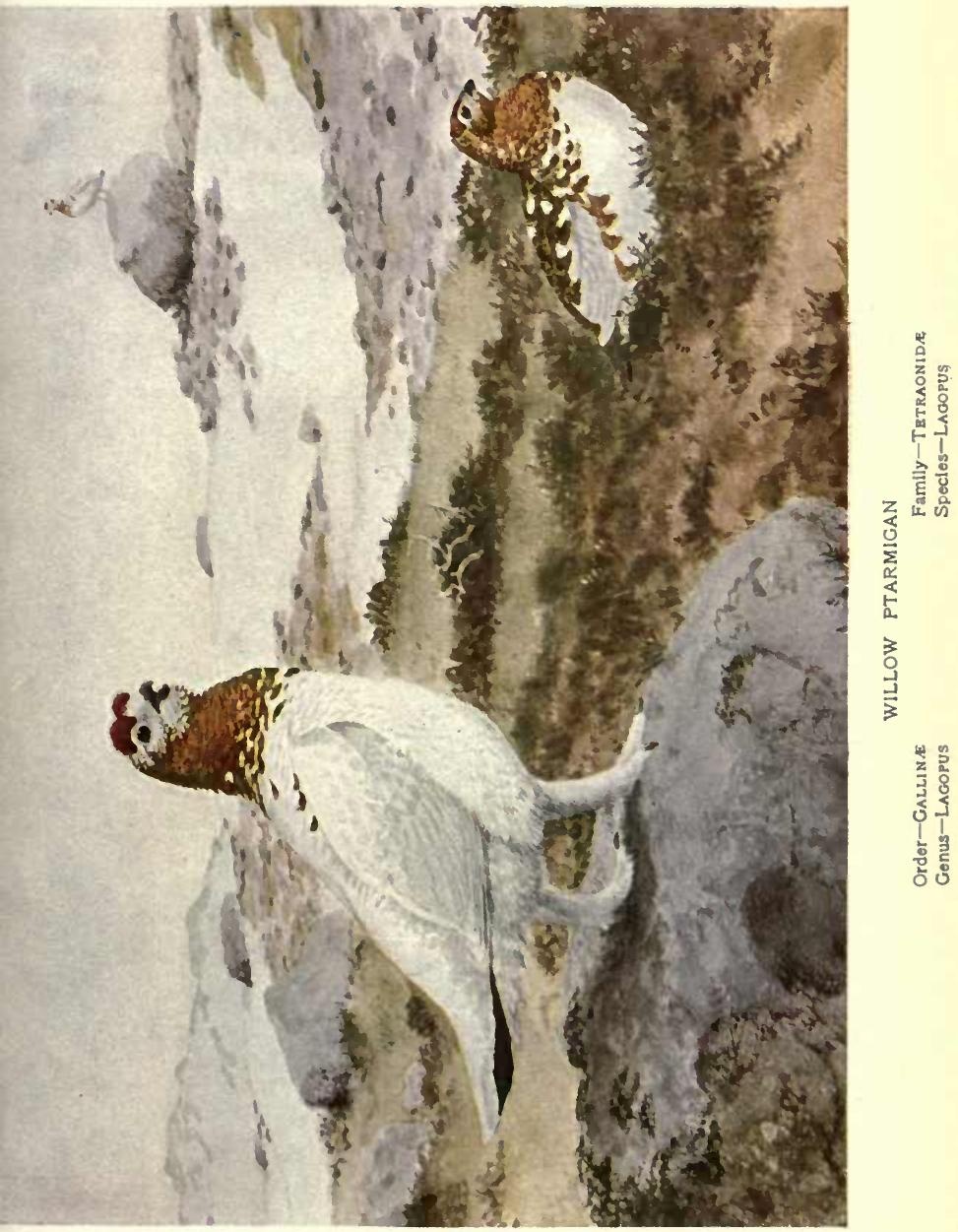



last tracts affected; so that by the middle of October some will be seen with dark feathers still predominating in the head and back. This, of course, gives much the same effect as at an early stage of the spring nolt.

The Willow Ptarmigan selects the site for its nest during the third week of May, and by the second week of June sets of eggs are usually complete. The nest is a slight depression in the moss on the open ground; usually the summit of a hummock is selected, as being a drier situation during the

\section{Nest} and Eggs period of early summer rains. A scanty lining of dry grasses keeps the eggs from actual contact with the saturated moss of the foundation.

The full set of eggs numbers from eleven to thirteen. They are very deeply and closely spotted and blotched with chestnut-brown, the effect being to render them difficult to distinguish from their surroundings. The female does all of the sitting, and when approached on the nest does not take flight until almost trodden upon. She then exhibits the greatest solicitude, tumbling about within a few yards of the intruder in the most distressing manner; but the male bird stays at a more discreet distance.

After the eggs are hatched, the precocious youngsters are accompanied by both parents. They then have the faculty, like that of young quails and grouse,

\section{Precocious Chicks} of concealing themselves at a moment's notice, while the parents attempt to call the intruder's attention elsewhere. The young at first are clothed with yellow and brown down; but before they are half-grown this is entirely replaced by loose-textured feathers, and even before half-grown the chicks are able to fly as readily as the adults.

In summer, the Willow Ptarmigan's bill of fare includes many sorts of insects, as well as green herbs. In the fall, the abundant crops of blueberries, heathberries, cranberries, and roseapples are freely resorted to, and these fruits again become available the following spring, when the retreating snow leaves them exposed.

The reader will have marveled already at the special and useful modifications in the habits and structure of the ptarnigan, which enable it to carry on a successful existence under so extreme a winter climate. Perhaps the most wonderful thing about the bird is its alternating adaptations to the opposite conditions of the short summer. Not only is the summer plumage of a totally different general color, as already described, but it is much less

\section{Molting}

dense than the winter plumage. The molts, however, do not affect the feathers of every part of the body. Those of the wings and tail are changed only at the time of the fall nolt which, in fact, is the only complete molt. The feathers of the feet and legs are not replaced in the spring ; but, as summer advances, the old feathers become brittle and acear off, until midsummer finds the birds with almost naked feet-a heavy feathering at that season probably being not only needless but a hindrance, as it would certainly become when wet.

The toe-nails in winter are so long as to project considerably beyond 
the generous feathering of the feet and toes, and probably serve as "icecreepers," of great use in walking or wallowing in crusty snow. But the extraordinary thing is that in summer the old toe-nails drop off, replaced by new ones growing from the quick!

In winter plumage, one set of feathers fails' to conform to the general whiteness-the tail-feathers. When the bird is at rest, the very long upper and under tail-coverts almost completely conceal these black tail-feathers, which are then closed together in narrow ranks. But, when the bird takes flight, the tail is widely spread, and a black "directive" marking flashes forth against the white background. In summer, the wing-feathers, persisting from the winter dress, are unnoticed in the

\section{Directive}

Markings

bird at rest; but, as the wings are spread in flight, they furnish a conspicuous "directive" pattern against the dark landscape, the black tail-feathers being then ineffective.

With all its marvelous fitness, the ptarmigan has much to contend with-the arctic fox, the weasel, the Rough-legged Hawk, the Gyrfalcon and the human hunter.

Looked at from the utilitarian standpoint, it affords, on the far northern frontier, an even more important game-resource than did the eastern gallinaceous birds in the early days of the settlement of the States. The weight of a Willow Ptarmigan is one and one-half pounds, so that each bird affords as much food as four or five Bob-whites.

In most of the vast North conditions yet remain primitive, so far as wild game is concerned. But, around the mining settlements in Alaska and Yukon Territory, the larger animals have been much reduced in numbers, or entirely used up, and many natural enemies of these birds have bzen reduced to small numbers. This doubtless has served to offset the effect of firearms, so that only in the near neighborhood of settlements has there been a notable decrease in the number of Willow Ptarmigans.

\section{Classification and Distribution}

The Willow Ptarmigan belongs to the Order Gallina, the Family Tetraonida, and the Genus Lagopus. Its scientific name is Lagopus lagopus lagopus. It inhabits the Arctic Zone generally, residing and breeding from the polar islands south to the Aleutian Islands, central Alberta (along the mountains), central Mackenzie, all around Hudson Bay and thence east to southern Labrador. In winter it ranges southward to the Saskatchewan River and Quebec. Two subspecies are recognized-Allen's Ptarmigan (L.l. alleni) of Newfoundland, and Alexander's Ptarmigan (L.l. alexandra) of the islands of southern Alaska west to the Shumagin group.

This and other Educational Leaflets are for sale, at 5 cents each, by the iNational Association of Audubon Societies, 1974 Broadway, New York City. Lists given on request. 


\section{THE CHICKADEE}

By EDWARD HOWE FORBUSH

\section{The National Association of Audubon Societies}

Educational Leaflet No. 61

Autumn has come-the waning of the year. The rising wind sighs among the lofty pines, shaking out old and yellowing needles from each tufted twig; and lightly they rain down, renewing the soft and springy carpet of the forest's floor. The somber sky, with leaden, hurrying clouds, portends the coming storm; jays cry mournfully; crows fuss and caw; but here comes Chickadee, flitting from twig to twig, as blithe and unconcerned as if it were always summer.

When winter winds rage in the forest and snow thickens the air,

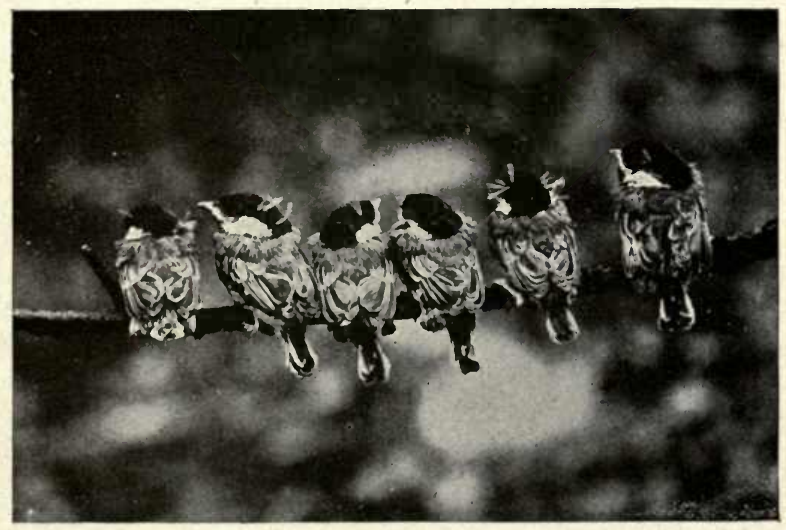

YOUNG CHICKADEES

From a Photograph by Herbert K. Job

Chickadee, merry and unafraid, hustles about amid the storm, fills his little stomach with insects, and, as the dreary night shuts down, hies him to some snug, sheltered refuge, where, warm and dry, he sleeps away the long winter night. Nothing daunts him but the ice-storm, which crusts the trees and covers his food with a heavy crystal sheath. Then, indeed, he creeps to shelter, wherever it may be found, and there he stays until the storm is spent.

Many children will recall the nursery-rhyme about "Little Tommy Tittlemouse," who "lives in a little house." The Clickadee belongs to the Titmouse family, which contains a large number of species scattered 
widely over the northern hemisphere, and highly serviceable to civilized mankind. Our Black-capped Chickadee may be found at some, if not all, seasons of the year in eastern Canada and the northeastern United States, where it is the prevailing woodland bird, particularly in winter.

A hole in a decayed birch-stump, two or three feet from the ground, a knot-hole in an old apple-tree, in a fence-post, or in an elm, forty or fifty feet from the ground, the deserted home of some woodpecker, or a

Digging a

Nest-hole nesting-box, may be selected by the Chickadee for its home. Commonly it digs out a nest-hole in the decaying stump of a birch or pine. It is unable to penetrate sound wood, for I have seen it try to enlarge a small hole in a white-pine nesting-box, but fail to start a chip. Often the Chickadee gains an entrance through the hard outer coating of a post or stump into the decaying interior by choosing, as a vantage-point, a hole made by some woodpecker in search of a grub. The Chickadee works industriously to deepen and enlarge this cavity, sometimes making a hole nine or more inches deep; and the little bird is wise enough to carry the tell-tale chips away and scatter them far and wide-something the woodpeckers are less careful to do. Sometimes the hole is excavated in the broken top of a leaning stump or tree, and once I found one in the top of an erect whitepine stump with no shelter from the storm.

The nest is placed at the bottom of the hole, and is made of such warm materials as cottony vegetable fibers, hairs, wool, mosses, feathers, and insects' cocoons. Every furry denizen of the woods, and some domestic animals, may sometimes contribute hair or fur to the Chickadee's nest. One nest was made entirely of cotton that had been placed in a nestingbox for the use of the birds.

The eggs vary somewhat in color, but are commonly white, spotted with reddish brown or finely marked with a paler

Eggs and Young shade. Both birds take turns in sitting, and the eggs hatch in about eleven days, the last one laid requiring sometimes twelve or thirteen days. The young leave the nest in about two weeks from the date of hatching. Sometimes two broods are reared in a season.

Chickadee is a very attentive little husband, often visits his mate while she is sitting on her eggs, and, besides relieving her of a part of this labor, frequently feeds her on the nest:

The Chickadee has named himself, and repeats his name often, with several additional dee-dees or chee-dees. Toward spring, he sometimes attempts to "pour out his soul in song," but a few jingling notes represent his finest efforts. The long, pensive, musical phobe, which he utters most often at that season, given with the first note accented and the last falling, is regarded by many writers as his song, but it is uttered by both sexes. The young in the nest give a faint and wheezing imitation of the chicadee, and, when they cry all together, their combined voices suggest the hissing of some huge snake. 


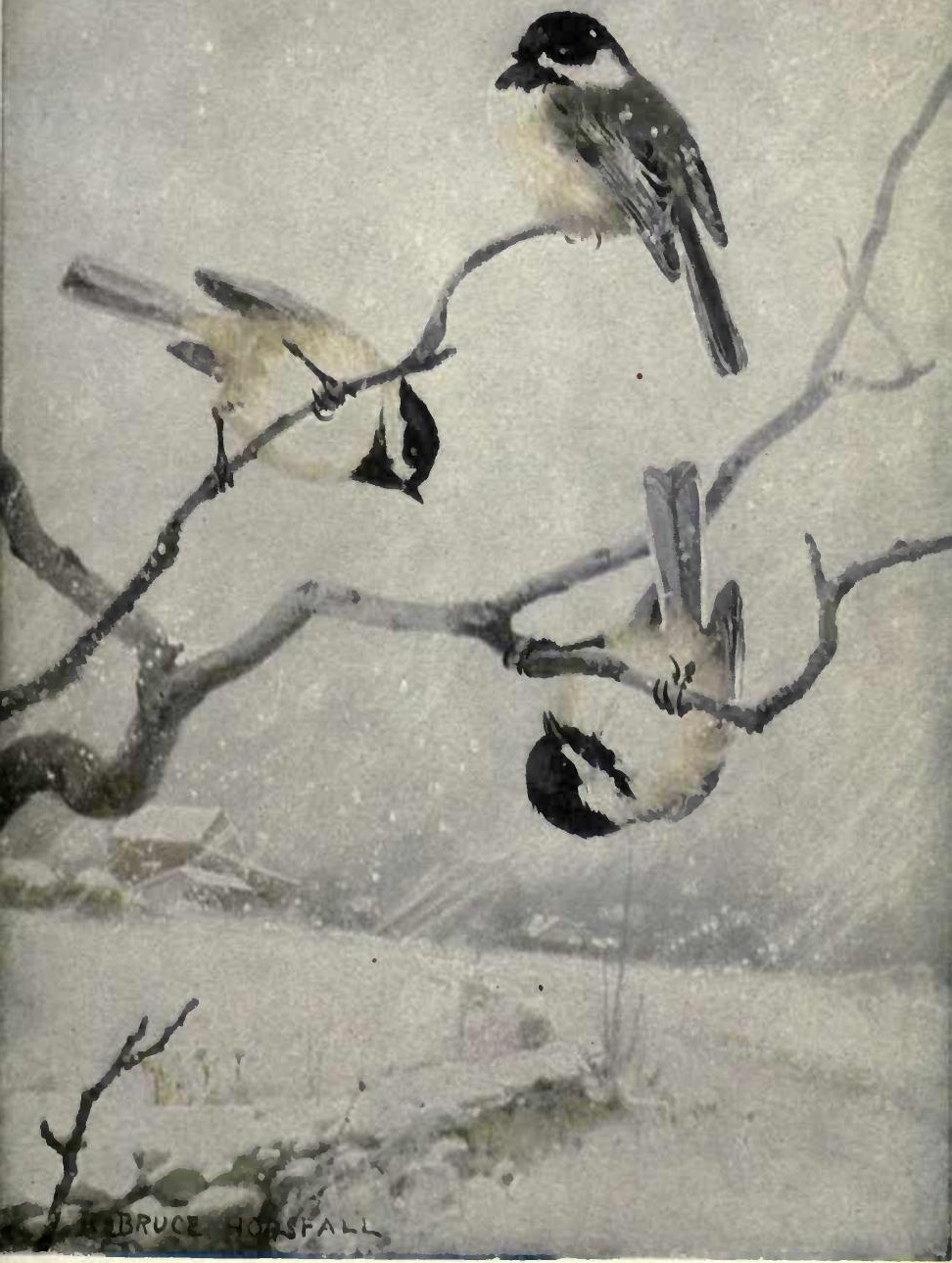

CHICKADEE

Order-PASSERES

Genus-Penthestes
Family-PARIDE

Specles-ATRICAPILLUS 
$x^{2}+25$

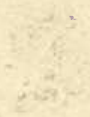


It's impossible to do more than touch upon the habits of this delightful bird in a leaflet like this. An adequate history of its bright and cunning ways, its many expedients and devices, would fill a book. Its chief apparent characteristics, from a human point of view, are courage, optimism, industry, activity, helpfulness, and joy in life. Emerson calls the Chickadee "a scrap of valor." One gifted writer says of its activity:

Chickadee refuses to look down for long upon the world; or indeed to look at any one thing from any direction for more than two consecutive twelfths of a second. "Any side up, without care," is the label he bears; and so with anything he meets, be it a pine-cone, an alder-catkin, or a bug-bearing branchlet; topside, bottomside, inside, outside, all is right side to the nimble Chickadee. . . . . Blind-man's buff, hide-andseek, and tag are merry games enough when played out on one plane; but when staged in three dimensions, with a labyrinth of interlacing branches for hazard, only the blithe bird whose praises we sing could promptly master their intricacies.

Although he is no fly catcher, the Chickadee takes insects on the wing with ease, and often catches in the air those which fall from the trees or from his own clutch.

I have seen a Chickadee reach after a flying insect,

\section{Expertness in} Fly-catching spring back downward, catch it in the air, and, turning a somersault, alight on a branch below. Another swung completely around a branch, like a gymnast doing the "giant swing." Every pose possible to a bird in a tree is taken by our little acrobat. His head turns quickly from side to side, his wings and tail flirt this way and that, as he turns, twists, pecks, and peers in pursuit of the insects which form the greater part of his food. Often his prying habits lead him to the hiding-place of a dozing owl, and then, no matter how large and powerful the enemy. Chickadee raises the alarm and sounds the attack, stirring and leading the feathered mob which gathers to execrate the common foe.

Notwithstanding his small size, this diminutive, black-capped bird is a leader. After the breeding-season, he is almost always the central figure and foremost spirit of a little band of warblers, nuthatches, creepers and kinglets, and is frequently followed by a woodpecker or two. In autumn, Chickadees gather into bands of one or more families and scour the

Chickadee's

Friends woods, searching out the most favorable localities for their food. Migrating warblers follow their call, knowing that it always leads them to food. Chickadee knows the ground; he has spied out the land, and invites all to join in his good cheer.

Follow the Chickadee, and you will see, sooner or later, most of the woodland birds. But he is not, by any means, confined to the woods. He visits the orchard and the shade-trees, picks up crumbs at the farmhouse door, enters the wood-shed, picks out borers from the firewood, and helps himself to the bacon that the farmer uses to grease his buck- 
saw. He confides in man to a remarkable degree. He hangs about the camp of the wood-chopper, looks for the "full dinner-pail," and sometimes comes and feeds from the hand. Many times in the woods his curiosity has led him to fly close about my head and peer with beadlike eyes into my face, and in numberless instances he has placed absolute confidence in those who have fed him in winter.

Probably no bird is more beneficial to mankind than is this little Titmouse. He lives very largely on insects destruc-

\section{Preserver} of Trees tive to trees; even in winter, much more than half his food consists of insects or their eggs. Myriads of the eggs of plant-lice, bugs, canker-worms, moths and bark-lice are eaten. No insect appears to be too large for him, and none too small to escape his sharp eyes and his little pointed bill. If a caterpillar is too big for him to swallow, he holds it under foot and pecks out its vitals, discarding the rest. If the larva is too large and powerful to be held in this way, the bird draws it over a twig, and, seizing both ends in his feet, swings back downward underneath the twig, pecking away until he has reduced the struggling captive to submission.

Many larvæ, including those of the apple-moth and the gipsy-moth, destructive bark-beetles, some weevils and scale-insects, are killed in myriads by the Chickadee. C. E. Bailey computed that one Chickadee would destroy 138,750 eggs of the canker-worm-moth in 25 days. Professor Sanderson estimates that $8,000,000,000$ insects are destroyed by

Protector of Foliage Chickadees each year in Michigan., My own experience, for ten years, has shown that trees may be absolutely protected from leaf-eating insects by attracting Chickadees through the year.

Our little Titmouse does not depend entirely on animal food, and therefore can exist when the trees are incased in ice and snow. He takes some weed-seeds, picks up a little waste grain, eats the seeds of pine, hemlock, alder, and some other trees, and a few winter berries, particularly those of the wax-myrtle, or bayberry. Sunflower-seeds, meat. suet, and nuts are relished when he can get them, but he is not known to have any harmful habits.

\section{Classification and Distribution}

The Chickadee belongs to the Order Passeres, Family Parida, and Genus Penthestes; its scientific name is Penthestes atricapillus atricapillus. This, the Black-capped Chickadee, is resident throughout the northeastern United States, and southeastern Canada. Three other subspecies have been defined. I-Longtailed Chickadee, $P$. a. septentrionalis, of the western interior and the Rocky Mountain region, from southern Alaska to Kansas. 2-Oregon Chickadee, $P$. a occidentalis, of the Pacific coast-region from British Columbia to Oregon. 3-Yukon Chickadee, $P . a$. turneri, of northern Alaska.

This and other Educational Leaflets are for sale, at 5 cents each, by the National Assnciation of Audubon Societies, 1974 Broadway, New York City. Lists given on request. 


\title{
THE HUDSONIAN GURLEW
}

\author{
By A. C. BENT
}

\section{The National Association of Audubon Societies Educational Leaflet No. 62}

A striking case of the survival of the fittest is seen when we compare the relative abundance of the three common species of North American curlews today with their status fifty years ago. Whereas, at that time, the Hudsonian Curlew was the rarest of the three, it is now by far the commonest. The vast flocks of Eskimo Curlews that formerly frequented the Labrador coast every summer or visited the New England coast at frequent intervals, have all disappeared. They were tame and unsuspicious, were easily decoyed, and were therefore slaughtered in enormous numbers on their feeding-grounds; and when autumn came they made a long migratory

\section{Declining} Curlews flight over the ocean from Nova Scotia to South America, in the course of which many undoubtedly perished in stormy weather.

The Long-billed Curlew, once so common all over the interior prairie regions, and even on the Atlantic Coast, has gradually been driven westward and northward, until it is now occupying a comparatively restricted range. It is so large and conspicuous a species that it has been much sought after by gunners, and, as it is not particularly shy, it has succumbed to persecution; moreover the cultivation and settlement of the prairies have driven it from, or destroyed, its favorite breeding-grounds. The Long-billed will probably be the next of the curlews to disappear, perhaps within the near future.

The reasons for the Hudsonian Curlew's success in the struggle for existence are not hard to find. Its breeding-grounds are in the far North, where it is never disturbed; it has no dangerous migration-route; it does not, ordinarily, migrate in very large flocks, which are susceptible to vicissitudes of

\section{Successful Qualities} weather and great slaughter at the hands of gunners; but, above all, it is a shy, wary, wily bird, quite capable of taking care of itself and wellfitted to survive. Like the Crow, it is more than a match for its enemies. There is no bird that has been more universally persecuted than the Crow, every man's hand is against it, yet it is as abundant as ever.

The Hudsonian Curlew, Jack Curlew, Short-billed Curlew, or Jack, as it is variously called, has often been mistaken by gunners for each of the other species, and some confusion seems to have existed, in regard to it, among the early writers on ornithology. Wilson does not seem to have recognized this species at all, or to have confused it with the Eskimo Curlew; and Nuttall's remarks are not altogether clear on the subject. 
There is so much variation in the length of the bill, at various ages, that young birds with shert bills are often mistaken for the Eskimo Curlew, and old birds with extra long bills are often called Long-billed Curlews, or Sickle-bills.

There are certain characters, however, by which this species may be recognized at any age. The Long-billed Curlew is much larger, the crown of its head is uniformly streaked, without any median stripe, and its axillars have no distinct bars; whereas the Hudsonian has a dusky crown with a light median stripe, and its axillars are distinctly barred with

Distinctive

Features dusky. The Eskimo Curlew may readily be distinguished by its uniformly dusky primaries; whereas in the Hudsonian the primaries have distinct buff spots, or partial bars, on the inner webs.

The Hudsonian Curlew is widely distributed over nearly all of North America and part of South America. Its breeding-range has not been fully workcd cut, but it is known to breed on the Barren Grounds of northern Mackenzie, and on the coast of Alaska from the mouth of the Yukon to Kotzebue Sound. Its principal winter range is on the western coast of South America from Ecuador to southern Chile, where it is very abundant; it also winters from Lower California to the coast of southern Honduras; and on the eastern coast its winter range extends from British Guiana to the mouth of the Amazon River.

The spring migration on the Atlantic coast reaches Florida during the latter half of March, the Carolinas about the middle of April, and Massachusetts about the middle of May. The dates vary greatly in different seasons, the northward movement being very gradual and the migration-period often much prolonged. On the Pacific coast, the main flight appears in southern California about the middle of March, progresses slowly northward, reaches Alaska about the middle of May, and arrives on the breeding-grounds in northern Mackenzie by the end of May.

Like most of the northern-breeding shore-birds, the Hudsonian Curlew moves off its breeding-grounds as soon as the Migration young are able to shift for themselves, and begins its summer wanderings, or starts on its southward migration, early in July. There are two main lines of flight, down the east and west coasts of the continent, as well as a more scattering flight through the central valleys and plains.

The eastward flight is from the west coast of Hudson Bay, where many birds linger through August, to the coasts of New England and suththward. A few Hudsonian Curlews migrate as far east as Labrador; the species has never been common there, but since the disappearance of the Eskimo Curlew it seems to have increased. On the New England coast the heavy flights often occur in September, and young birds often linger until well into October.

The southward movement in the fall is very deliberate, and the last of the birds do not pass through the West Indies to South America until 


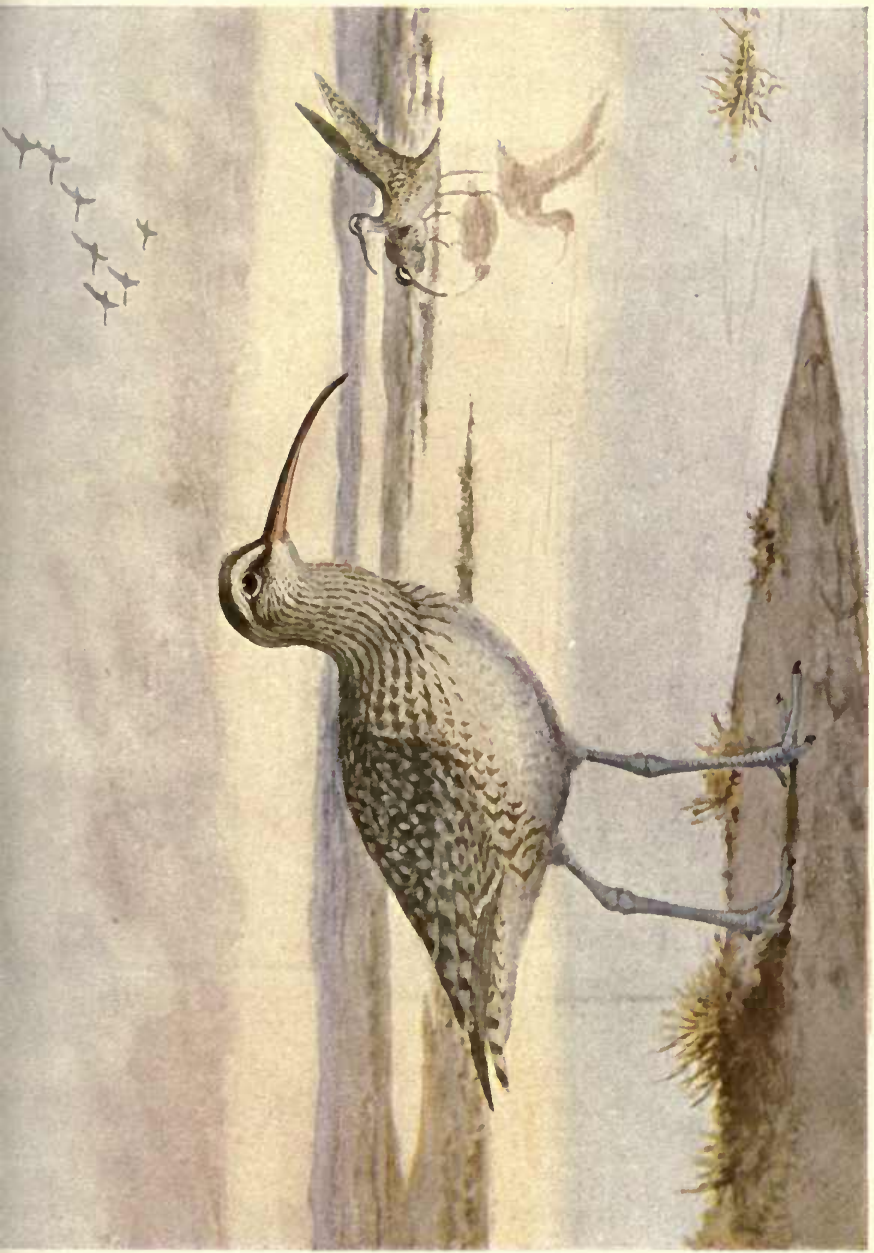

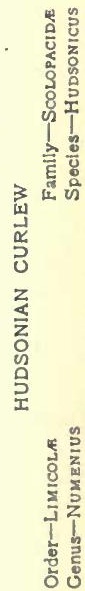



November. As with all the shore-birds, the early flights are composed almost entirely of adult birds, and the flights of young birds follow, on an average, about a month later.

The Pacific Coast flights occur on corresponding dates. The early flights of adults reach California about the middle of July; and on the coast of Peru they make their appearance early in August. Young birds are common about Nome, Alaska, until the first of September, when large numbers are brought into the markets, with a few Bristle-thighed Curlews.

Very little seems to be known about the nesting habits of the Hudsonian Curlew. Mr. MacFarlane found them breeding on the treeless Arctic tundra near the mouth of the Anderson River, where he took several sets of eggs late in June and early in July; the nests were merely depressions in the ground lined with a few withered leaves. J. O. Stringer described a nest found on an island in the lower Mackenzie River, as a pile of grass, moss, and weeds. Joseph Grinnell reported this species as

Nest and Eggs breeding in the Kowak Valley, Alaska, between June I4 and 20, I899.

The eggs vary in color from creamy drab to brownish buff, and are more or less heavily spotted with various shades of brown. Young birds in the fall may be distinguished from adults by their shorter bills, and by the conspicuous buff spots on the upper parts.

The Hudsonian Curlew is more of a littoral species than either of the others, and seems to prefer to frequent and feed on the seacoast. At low tide it resorts to the recently uncovered flats and beaches, where it can pick up marine insects, worms, and small crustaceans. George H. Mackay says of its feeding habits in Massachusetts: "The Hudsonian Curlew is a tide bird, frequenting the sand flats near the edge of the water, when they become uncovered, and resorting to marshes and uplands when driven from the former by the in-coming tide. They feed on fiddler crabs, grasshoppers, and the large gray sand-spiders $(L y \cos a)$ which live in holes in the

Gathering

Food sand among the beach-grass adjacent to headlands; huckleberries, which they pick from the bushes; and on beetles. All this is usually mixed with coarse gravel.

When a flock of these birds is on the ground where they have been feeding, they become scattered, twenty-five or thirty birds covering fifteen or twenty yards apiece. At such times they do not appear to be particularly active, moving about in a rather slow, stately manner, although once in a while I have seen them run." On their inland resorts they prefer to frequent the shores of lakes, ponds, and marshes, but are frequently seen on the upland pastures, feeding on grasshoppers, beetles, or berries.

The flight of the Hudsonian Curlew is rather slow and steady, but strong and protracted. When migrating, they usually fly high in the air in small flocks, much after the manner of ducks and geese. During the spring migration on the coast of South Carolina, they congregate in im- 
mense flocks, sometimes numbering several thousand, where they feed about the shores of the islands off the coast, roosting on the outer sandbars, and flying to and from their feeding-grounds in dense flocks, often close to the water. On the New England coast, they

\section{Manner of} Flight

imitation of their whistle. seldom fly in large flocks, and are often seen singly, circling high in the air, and responding readily to an

It is useless to attempt to stalk the adult birds, and they will not ccme to the decoys unless the blind is well concealed in the beach-grass or among bushes. Young birds, on the contrary, are quite unsuspicious and will decoy well. When coming to the decoys, they set their wings and scale for a long distance, in open formation and scanning the ground carefully. Their keen eyes will detect the slightest movement, or the presence of any unusual object, which will cause them to wheel or spring into the air and fly away.

Their loud, whistling notes are characteristic and easily imitated. Mr. Mackay has well described them as follows: "They make two notes, one a very clear, penetrating, staccato whistle, repeated four or five times in quick succession, and which is very far-reaching. It is given when flying, also when alarmed, and on taking flight. The other consists of two low, straight whistles, or notes, when a flock is Notes alighting. Flocks also make a rolling note, lasting as long as it would take to count six or seven. The sound is similar to that produced by a boy's lead bird-whistle filled with water. It is uttered when the birds approach, and are over a marsh or feeding-ground, at an altitude of sixty or seventy yards. I have never heard of its being made by single birds." They also have a soft musical curlew note, more often heard in the spring.

\section{Classification and Distribution}

The Hudsonian Curlew belongs to the Order Limicole, the Family Scolopacida, and the Genus Numenius. Its scientific name is Numenius hudsonicus. It ranges throughout both North America and the northern half of South America, mainly near the coasts, and winters in tropical America.

This and other Educational Leaflets are for sale, at 5 cents each, by the National Association of Audubon Societies, 1974 Broadway, New York City. I.ists given on request. 


\title{
RUFFED GROUSE
}

\author{
By GEORGE BIRD GRINNELL
}

\section{The National Association of Audubon Societies}

Educational Leaflet No. 63

The Ruffed Grouse is found all over north-temperate North America, in situations adapted to its habits. Except by sportsmen and real woodslovers, it is seldom seen, for its life is snent chiefly in thick woods or in the depths of swamps, or along steep, forest-clad hillsides. In thickly settled districts, where much pursued, it is very wary, walking noiselessly away out of sight if it hears an approaching step, or crouching and lying concealed if the intruder comes suddenly upon it; or, when it believes itself discov-

\section{Haunts} ered, rising from amid a cloud of dry leaves with a roar of wings whose thunder often startles even the seasoned woods-walker.

It has different names in different sections: "pheasant" in the South and in parts of the West, and "partridge" in New York and New England.

The Ruffed Grouse is a hardy dweller of the North, and fears neither bitter cold nor deep snows. It loves the rough country. Flat grassy plains have no charm for it, nor does it flourish where winters are mild and spring breezes early and genial. Dark forests of pine and hemlock, rock-strewn mountain-sides, and tangled, vinegrown alder swamps suit it best-dim, silent places where only the shy wild things come. Neither heat nor cold trouble it. If for weeks the ground is covered deep with snow, the grouse takes to the tops of the trees, feeding on the buds of apple, poplar, birch, ironwood, and willow, and comfortably pulls through seasons of

Food scarcity until the ground is again bare, and it can resume its customary diet of berries, green leaves, fallen nuts, and the fruit of the skunkcabbage.

In the summer, the birds feed on the leaves of growing plants, on insects, grasshoppers, and crickets; and in autumn they depend largely on fruit-berries of all sorts, wild grapes, various nuts, and fallen apples, at which they like to peck.

One of the early spring signs that Ruffed Grouse are about is their drumming. It is a low, hollow murmur, like distant thunder, macle by the male bird, while standing on a log, stone or stump, and rapidly beating his wings. Few subjects have been more discussed by sportsmen-scientific and non-scientificthan this mysterious sound. How is it made and

Drumming why? The complete answer to the first question was given only a few 
years ago, when Dr. C. F. Hodge photographed a Ruffed Grouse in the act of drumming, and did this over and over again. It was then seen that, instead of doing what tradition had declared-beating his wings against a stone, a hollow log, or his breast-the grouse, in fact, beats them only against the air. While he performs this act, the bird throws himself into various curious and fantastic positions, which one would never expect of a Ruffed Grouse.

Obviously, the drumming is a mating call; though it is quite possible that it may also be a challenge. It is performed in autumn as well as in spring. It is said that on occasions sportsmen, by imitating the drumming sound, have caused grouse in the woods to come to them.

The Ruffed Grouse's nest is made, and she begins to lay her eggs, in May; and it is early June, or the middle of the month, before the tiny young have hatched. When the brood leaves the nest, there Nesting may be from a dozen to twenty of the little fellows, hardly as large as one's thumb, very active on their feet, and covered with a silky, tawny down of various shades. Only by the merest accident and the greatest good fortune can one hope to see one of these little families, and to watch it undisturbed. Usually, if they have any warning, the tiny chicks squat motionless among the dead leaves on the ground, where they escape notice; while the anxious mother, pretending to be hurt and unable to fly, flutters along the ground, trying to lead the enemy to pursue her and to leave the young ones. The ruse is almost always successful. Dog, boy, and man are quite sure to be deceived, and to follow the fluttering bird, which acts as if she were sorely hurt and could be seized the next moment; but, after she has enticed the pursuer away from the point of danger, she takes wing and flies swiftly away.

Once, passing quietly through some big woods, I saw, beyond a little rise only a few steps distant, a dark spot on the leaves, which I recognized as a mother-grouse hovering her brood with outspread Young wings. She was as much surprised as I, and, losing her pressnce of mind, flew at once, while from the place where she had been nesting fifteen or twenty tiny young streamed out in every direction. Of most of these $I$ at once lost sight, but on one I kept my eye, and presently, taking two or three steps forward, picked it up from the ground. It crouched on my palm, unafraid, looking at me with a bright, soft eye. Perhaps it was a week old, for the quills of the wings were about a quarter of an inch in length. Putting it down on the leaves, I slowly withdrew to a little knoll, forty or fifty feet distant, and there listened and watched for the mother-bird, which soon came creeping cautiously through the undergrowth until within a few feet of where her babies had been left. There she mounted a stump and talked to them in low notes, and there I left her, easy in mind, I hope, about the little family.

When autumn comes, and berries and seeds are ripe, and brown nuts 


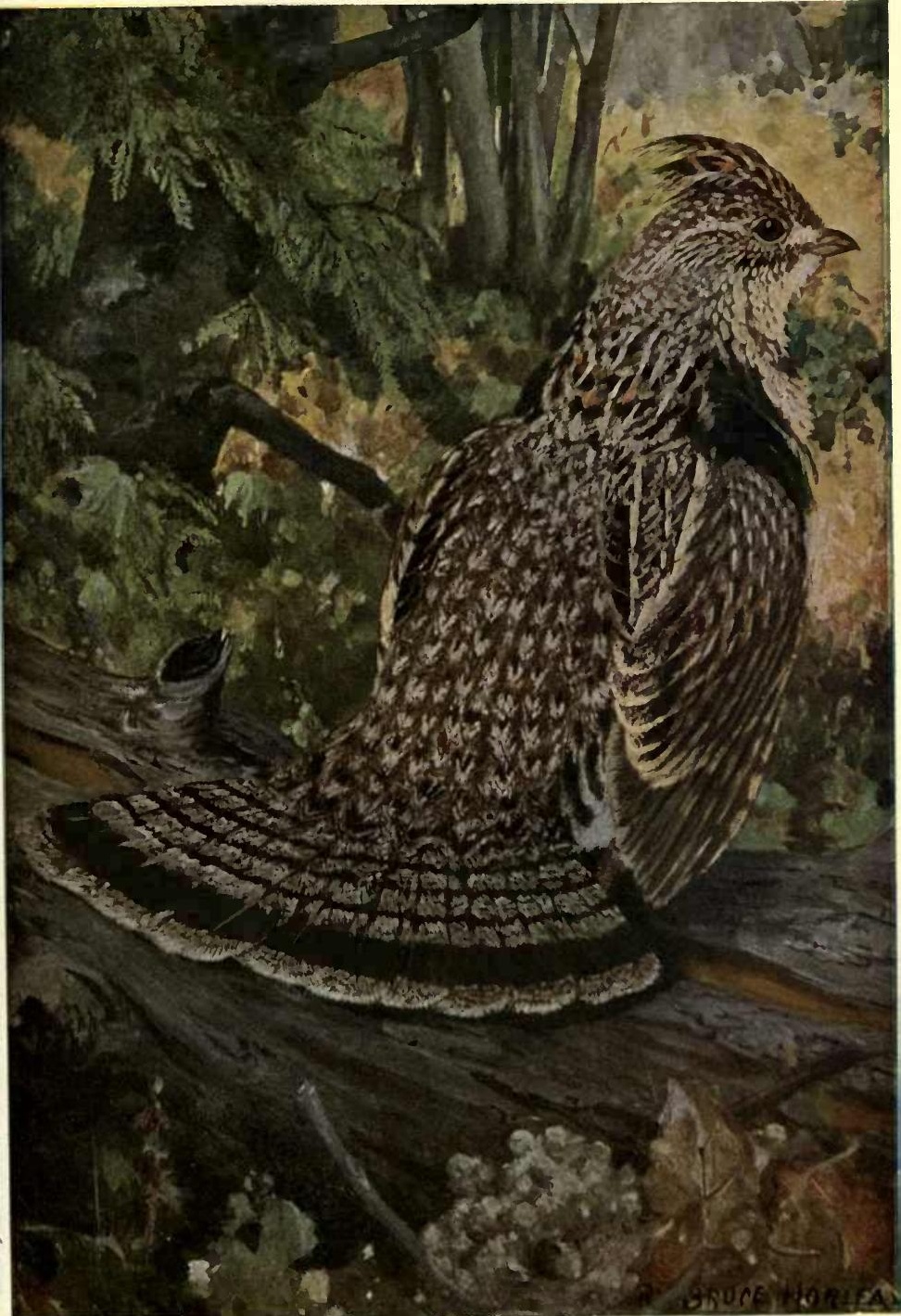

RUFFED GROUSE 


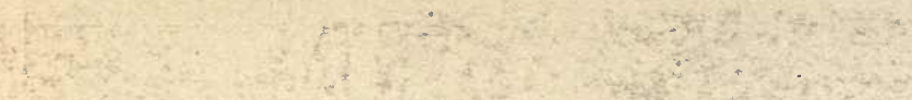

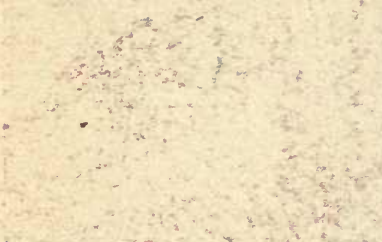

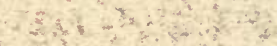

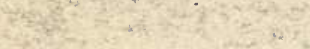

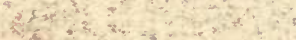

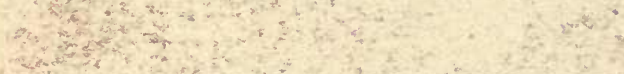

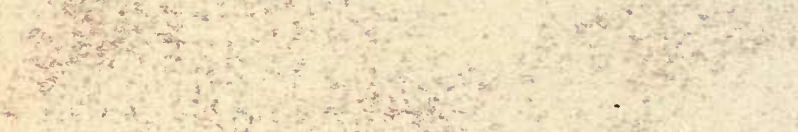

$$
\begin{aligned}
& \because 3 x^{2}=x^{2}=
\end{aligned}
$$

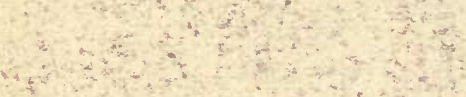

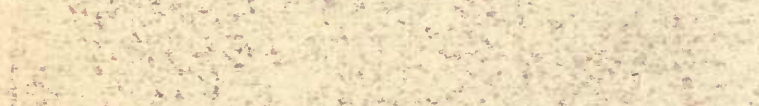

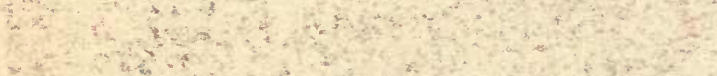

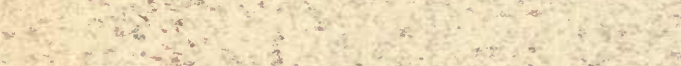

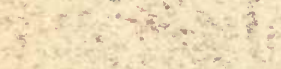

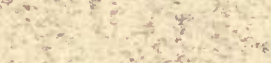$$
\text { \% }
$$$$
\text { t. }
$$

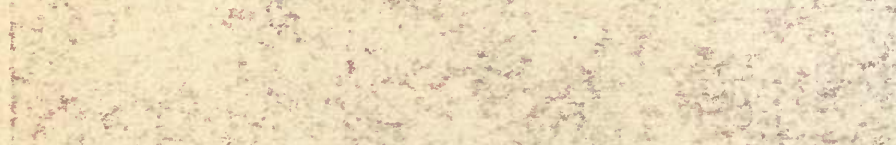

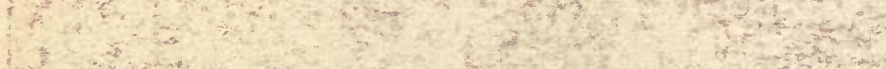

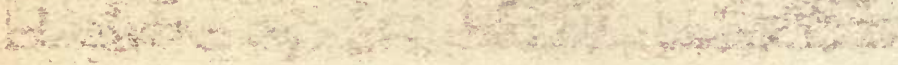


rattle down from the chestnut-trees, or the wind scatters three-cornered beech-nuts among the thick leaves, the Ruffed Grouse live well and become sturdy and fat, preparing for the winter. Their feathers thicken, the hair-like covering on the legs gets long and warm, and from the side of the toes grow out little horny comb-like appendages, which perhaps may serve in some degree as snow-shoes, supporting the birds when they walk over the deep, light snow of the woods. In the northern country, when the ground is heavily covered with snow, the grouse are reported sometimes to dive into the light snow-drifts to spend the night, protected from the cold of the upper air by the blanket of snow above them.

In winter the Ruffed Grouse is very likely to seek out the sunny side of thick woods and swamps, and in the middle of the day to sit there, preening itself and enjoying the grateful warmth. In spring and summer-and even in

Habits in Winter winter-I have found fresh places where the grouse had dug out dusting-places in the soil, precisely as donestic chickens do in warm weather.

The habits of the Ruffed Grouse vary with the locality in which it is found and the conditions of its life. In wild regions, where man is seldom seen, where the roar of firearms is not heard, and its only enemy is lynx or fox or hawk or owl, it is the most trusting of birds. If the traveler comes immediately upon it, it is likely to fly up on the low branch of a tree, and examine him with interest and curiosity. If, by chance, he should fire three or four pistol-shots at it without hitting it, it does nothing more than turn its head from side to side, as if curious to discover the cause of the unusual sound. In parts of the Rocky Mountains or of Canada, a grouse will sometimes sit on a limb until a noose, tied to the end of a pole, is slipped over its head, or a stick thrown by a vigorous hand knocks it from its perch, or an Indian boy shoots it with a blunt arrow.

In the East, where it is constantly pursued, the bird hast lost its simplicity and trustfulness. It has learned the lesson of self-protection from dog and gun. It flies at the sound of the human voice a long way off; is bold and

Lessons

in Caution fearless, or cautious and evasive, as the occasion demands; practises a great variety of stratagems, and is abundantly able to cope with most gunners. While birds without experience are obviously less able to protect themselves, the old stagers who have survived one or two shooting seasons possess a wisdom which often seems fairly uncanny.

Sportsmen generally believe that, from the middle of October until sharp frosts begin to chill the waters of streams and swamps, the Ruffed Grouse, like their distant cousins, the quails, wander about more or less, and are not to be found in their usual haunts. This is called the "running season" or "crazy season." Certain it is, that at this time of the year there is more or less shifting from place to place by the grouse, who tend to desert their summer resorts and to move into places where, during the 
season of extreme cold, food and shelter will be better. Movements like this take place with many birds and mammals. We used to see such

\section{Autumnal \\ Wandering} shiftings with buffalo, elk, deer, and antelope, and certain other American grouse, and there seems no doubt that they take place in the case of the Ruffed Grouse and Bob-white. At all events, in the mild weather of the middle fall, Ruffed Grouse are often found in extraordinary and unexpected places, as outbuildings, the trees or lawns near houses in private places, and even in the middle of a mowing-lot. After the first cold weather, however, the birds are likely to choose a swamp or woods for winter quarters.

A good dog for Ruffed Grouse is exceedingly hard to find. He should have a keen nose, great caution, and the more experience the better. The scent given forth by this bird so excites the ordinary dog that he loses all idea of caution, and runs about as if demented. In his noisy racing back and forth, he alarms the grouse, which thus has ample opportunity to lay plans to foil its pursuers. The wise old "partridge dog" acts very differently. Naturally intelligent, he understands the difficulties of his task, and his experience in the ways of many grouse in other

\section{Wisdom of Dogs} years causes him perfectly to comprehend the difficulties of the task required of him. He works close to the gun, and, at the faintest suggestion of the scent of a grouse, stops and waits for his master to come up. Then cautiously and in silence he works out the scent, and satisfies himself as to what the bird has done and probably now is doing; and then he tries to be a little more cunning than the bird. Sometimes such a dog, when he finds that a grouse is persistently running before him, will leave the trail, make a wide circle, and go around beyond the bird, coming back from the point toward which it was running, with the purpose of stopping it and making it lie until the gunner comes up.

The Ruffed Grouse is so persistently shot that in the East there are now few districts where good shooting can be had. In less thickly populated districts-as parts of New England, New York.

Decrease Michigan, and Wisconsin-this bird is still abundant. Even if the stock of grouse in southern New England and in southern New York has been brought down very low, extermination as yet has hardly come wherever covers suited to the Ruffed Grouse remain.

\section{Classification and Distribution}

The Ruffed Grouse belongs to the Order Gallina and the Family Tetraonida. Its scientific name is Bonasa umbellus. The range of the species extends from the southern Alleghenies, Kansas, Colorado and northern California to Alaska, central Quebec and Nova Scotia. Four subspecies are distinguished: T. u. umbellus, of the eastern-middle United States; T. u. togata, of eastern Canada, New England and northern New York; $T$. $u$. umbelloides, the Gray Ruffed Grouse, of Alaska and Yukon; and T. u. sabini, Sabine's Ruffed Grouse, of the Northern Pacific Coast.

This and other Educational Leaflets are for fale, at 5 cents each, by the National Association of Audubon Societies, 1974 Broadway, New York City. Lists given on request. 


\section{THE EMPEROR GOOSE}

By EDWARD W. NELSON

\section{The National Association of Audubon Societies Educational Leaflet No. 64}

Among all the wild geese which make their summer home in the far North-both in the Old and the. New World - the Emperor Goose is one of the least known and most beautiful. Its snowy white head, dusky throat, satiny gray body, on which each feather is marked by a black crescent and white margin, and the brilliant orange feet, make a strikingly handsome combination of colors. When the males first arrive on their breeding-grounds in spring, the beauty of their plumage is remarkable, but much of its satiny luster goes with the advancing season.

Although the breeding-range of the Emperor Goose covers parts of two continents, yet perhaps it is more restricted in its territory than any other species of northern goose. Its summer home lies along the coast on both sides

Arctic Home of Bering Straits, but so far as we know the vast majority of them breed in Alaska, mainly on the islands of the lower part of the Yukon delta, and thence southward nearly to the mouth of the Kuskokwim River. Considerable numbers also breed on St. Lawrence Island, and on the coast of northeastern Asia, where they arrive as soon as the tundra is free from snow. Their main wintering place appears to be on the southern side of the Peninsula of Alaska and the Aleutian Islands. The Aleuts know them as "Beach Geese," owing to their persistent occupation of the seashore. Stray individuals wander down the American coast in winter even to northern California, and occasionally are driven by gales to Hawaii.

When I was preparing to go to Alaska, some years ago, the Emperor Goose, Steller's and Fischer's Eiders, and the Aleutian Tern were names to conjure with, and the anticipation of studying these birds in their remote northern homes filled me with joy. In the North, my headquarters were at St. Michael, on the coast of Bering Sea, about sixty miles north of the Yukon delta. Here Emperor Geese rarely occurred except stray parties-visitors to the marshy coast-plain in fall. I made a sledge-journey one winter through the Yukon delta and across the tundras southward to the Kuskokwim, and found the Eskimos in that area wearing "parkies," or outer garments, made of the skins of Emperor Geese sewed to-

\section{Material for}

Overcoats gether, and learned that great numbers of these birds nested there each spring rarely above the upper limit of the tide in the sluggish streams of this low plain. All available observations of the habits of this bird 
show it to be a strictly salt-water, coastal species in both summer and winter. Its food is sought between tide-lines, either on oozy flats, as at the Yukon mouth, or along the rocky beaches of the wild Aleutian shores.

One spring, during my residence at St. Michael, it became possible to fulfil my long-cherished desire to visit the breeding-grounds of these geese and of many other water-fowl in the Yukon delta, and I left St. Michael early in May with an Eskimo and a dog-sledge. The tundra was still clothed in winter white, except here and there a bare spot on the sunny side of a knoll, and the sea was covered with unbroken ice to the far horizon. The hoarse, crowing notes of the Willow Ptamigan

Spring on the

Tundra were beginning to be heard on the tundra, and occasional scouts from the coming army of White-fronted and Cackling Geese passed high overhead, spying out the land; yet the day I started the temperature was well below zero.

At the border of the Yukon delta, Eskimos familiar with the country were employed to lead us to the desired nesting-ground of the Emperor Goose. Nearly half a day's journey among the maze of ice-covered channels of the delta brought us to a low, flat island, where our guide assured me many "Nachau-thluk" would soon arrive, to rear their young. It was a bare, desolate spot, with only a few scattered alders on the upper side of the islands, and an unbroken view out over the frozen sea to the west. A tent was put up on a slight rise and, after a stock of drift-wood had been gathered, the guides took the sledge and left me with my Eskimo companion to await the arrival of the birds. Later, when the ice went out, they returned for me with kyaks.

A few White-fronted and Cackling Geese gave noisy evidence of their presence, but it was not until May 22 that the Eskimo brought in the first Emperor Goose-a male in beautiful spring plumage. After this, small flocks came in rapidly until they were plentiful all about us. They arrived quickly, skimming along near the ground, quite unlike the other geese, which appeared high overhead with wild outbursts of clanging cries, answered by those already on the ground. The river-channels and the sea were still covered with ice, and the tundra half covered with snow.

At first, the Emperor Geese were difficult to approach, but as their numbers increased they became less shy. When on the wing, they were

\section{Coming of the} Geese easily distinguished from the other geese, even at considerable distances, by their proportionately shorter necks and heavier bodies, as well as by their short, rapid wing-strokes, resembling those of the Black Brant. Like the latter, they usually flew near the ground, rarely more than thirty yards high, and commonly so close to the ground that their wing-tips almost touched the surface on the down stroke. While flying from place to place, they give at short intervals a harsh, strident call of two syllables, like kla-ha, $k l a-h a, k l a-h a$, entirely different from the note of any other goose I have ever heard. A group of them on a sand-bar or mud-flat often utter lower. more cackling notes, in a conversational tone, which may be raised to 


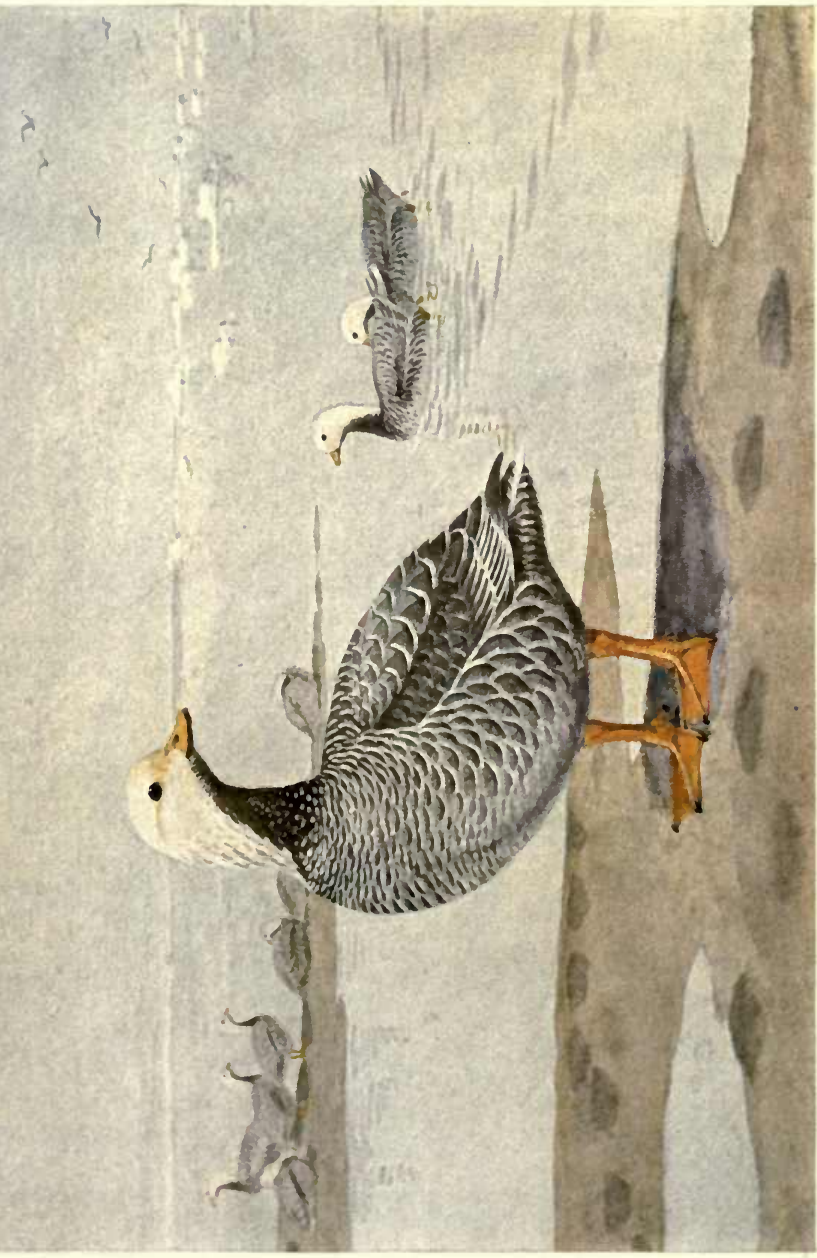

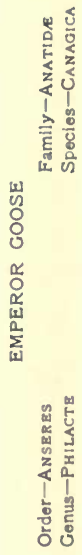





\section{The Emperor Goose}

welcome new arrivals. They are much less noisy than either the Whitefronted or Cackling Geese, which often make the tundra resound with their excited cries. Occasionally I could cause a passing flock to leave its course and swing in close to my place of concealment by imitating their flight-notes.

Almost at once after their arrival on the islands, the Emperor Geese appeared to be mated, the males walking around the females, swinging their heads and uttering low lovenotes; and incoming flocks quickly disintegrated into

\section{Mating}

pairs which moved about together, though often congregating with many others on flats and sand-bars. The male was entremely jealous and pugnacious, however, and immediately resented the slightest approach of another toward his choice; and this spirit was shown equally when an individual of another species chanced to come near. When a pair was feeding, the male moved restlessly about, constantly on the alert, and at the first alarm the pair drew near one another, and just before taking wing uttered a deep, ringing $u$-lugh, $u$-lugh; these, like the flight-notes, having a peculiar deep tone impossible to describe.

At low tide, as soon as the shore ice disappeared, the broad mudflats along shore were thronged with them in pairs and in groups. They were industriously dabbling in the mud for food until satisfied, and then congregated on bars, where they sat dozing in the sun or lazily arranging their feathers. By lying flat on the ground and creeping cautiously forward, I

Nests and

Eggs repeatedly approached within thirty or forty yards of parties near shore without their showing any uneasiness.

Early in June, they began depositing eggs on the flat, marshy islands bordering the sea. The nests were most numerous a short distance back from the muddy feeding-grounds, but stray pairs were found nesting here and there farther inland. One must have lain with neck outstretched on the ground, as I afterward found was their custom when approached, for the Eskimo and I passed within a few feet of each side of her; but, in scanning the ground for nesting birds, the general similarity in tint of the bird and the obvious stick of driftwood beside her had completely misled our sweeping glances.

The same ruse misled us several times; but on each occasion the parent betrayed her presence by a startled outcry and hasty departure soon after we had passed her and our backs were presented. They usually flew to a considerable distance, and showed little anxiety over our visit to the nests. When first laid, the five to eight eggs are pure white, but they soon become soiled.

Breeding

Habits

When the complement of eggs to be laid approaches completion, the parent lines the depression in the ground with a soft, warm bed of fine grass, leaves, and feathers from her own breast. The males were rarely seen near the nests, but usually gathered about the feeding-grounds with others of their kind, where they were joined now and then by their mates. 
The young are hatched the last of June or early in July, and are led about the tundras by both parents until August, when the old birds moult their quill-feathers and with the still unfledged young become extremely helpless. At this time, myriads of other geese are in the same condition, and the Eskimos made a practice of

\section{Catching}

Geese setting up long lines of strong fish-nets on the tundras to form pound-traps, or enclosures with wide wings leading to them, into which thousands were driven and killed for food. The slaughter in this way was very great, for the young were killed at the same time.

Fortunately, in 1909, President Roosevelt made a bird-reservation covering the delta of the Yukon and the tundra to the southward, which includes the main breeding-ground of the Emperor Goose, and thus took a long step toward perpetuating this fine bird.

\section{Classification and Distribution}

The Emperor Goose belongs to the Order Anseres, the Family Anatidae, and the Genus Philacte. Its scientific name is Philacte canagica. Its habitat is both shores of Bering Sea and adjacent Arctic coasts and islands, and its winter range is southward on the American coast to northern California. 


\section{THE CRESTED AUKLET}

By CHARLES HASKINS TOWNSEND

\section{The National Association of Audubon Societies Educational Leaflet No. 65}

This is a bird of the far North, frequenting the coasts and islandis of Bering Sea and the North Pacific Ocean. We first got acquainted with the Crested Auklets at the Pribilof Islands, where they abound, and afterward saw them in Bering Strait, and above the Arctic Circle at Kotzebue Sound. Later on, in the fishery surveys by the steamship Albatross, we saw them from Kadiak Island and the Alaska Peninsula through the whole Aleutian Archipelago, and beyond to the Commander Islands off Kamtscliatka. The bird is also found along the Kuril Islands, down as far as Japan on the western side of the Pacific. Rich as were our experiences with auklets in many of these places, they did not prepare us for what we were to see in the Shumagin Islands, south of the Alaska Peninsula.

On the evening of August I, the Albatross came to anchor in Yukon Harbor, at Big Koniushi Island of the Shumagin group. While the ship was working her way into this wild and uninhabited bay, everyone noticed the increasing numbers of auklets. The farther in we went the more numerous they became, until the Captain called me to the bridge to tell hin what I could about them.

The birds were nearly all of the crested species, and were present in myriads. The surface of the water was covered with them, and the air was filled with them. Large, compact flocks launched themselves into the air from the lofty cliffs, and careered toward the vessel with great speed and whirring of wings. The Crested Auklets were here more numerous than were the "Choochkies" (Least Auklets) at St. George, in the Pribilofs, celebrated as the center of abundance for that species.

Twilight did not come until after nine o'clock, and during the long evening the birds were amazingly active. Flocks of them continued to come in rapid succession from the cliffs, many passing close to the ship at high speed

\section{Amazing}

Numbers and swinging about the harbor. After the anchor was dropped near the cliffs, a loud blast of the whistle made the auklets still more abundant. The bird-legions swept from the cliffs until the misty air and the water about the ship was alive with them. It was a memorable ornithological display, and when darkness came the birds were still moving actively.

These birds appeared to be nesting chiefly in crevices in the cliffs, although they could be heard under the boulders near the beaches. We did not stay long at Yukon Harbor, and I have always wanted to revisit the place and get better acquainted with the metropolis of the auklets. At the Pribilofs, we found the birds apparently more abundant under 
boulders near the beaches than in high cliffs. In seeking the nests of the Crested Auklets, and in fact the nests of any of the auklets, one needs a tool not often used by the bird student-a crowbar.

To discover the nesting-places is easy. One has but to walk along the great ridges of volcanic stones thrown up by the sea. The stones are rounded and sea-worn pebbles, but they are gigantic pebbles and cannot be readily removed. The auklets go far down among them, perhaps three or four feet, and can be heard chattering there during any part of the nesting season.

The natives attempted to show us the nests. They lifted or rolled

Dwelling among the heavy rounded stones for half an hour, until there Boulders was a circle of them around us waist high and fifteen feet wide. They worked in the central depression, carrying or rolling stones until the task became hopeless, and still the auklets were chattering underneath the stones all about. Edward W.

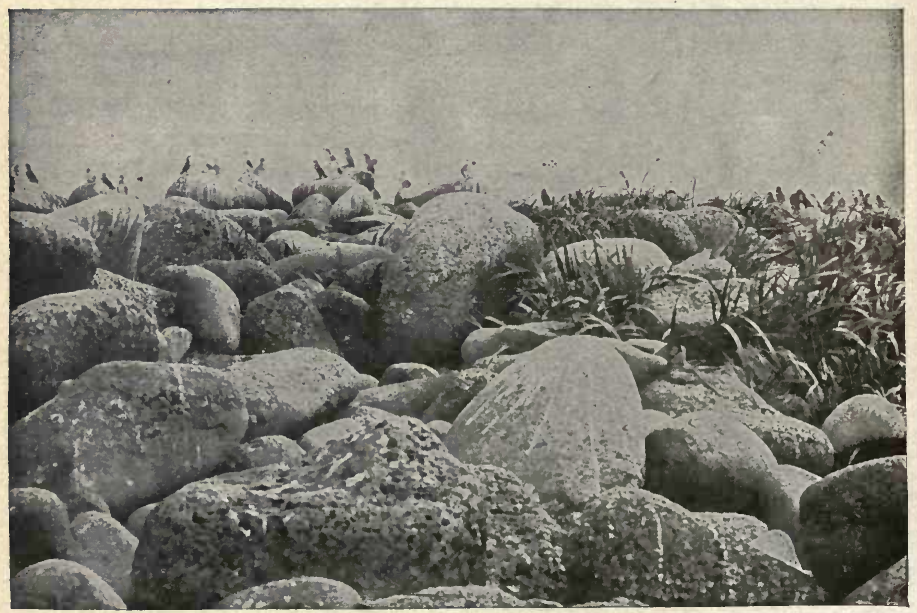

A FAVORITE NESTING-PLACE OF AUKLETS, PRIBILOF ISLANDS, ALASKA Photographed by Dr. C. H. Townsend

Nelson writes that on the northern islands of Bering Sea, St. Matthew, St. Lawrence, and the Diomedes, the eggs are sometimes deposited in exposed places, with little attempt at concealment. A set consists of a single egg, white, with sometimes a few dark blotches, and measuring on the average 2.10 by $\mathrm{I} .40$ inches.

We found that a considerable part of the food of this and other kinds of auklets consisted of amphipod crustaceans, or beach-fleas, as they are called, when found under bits of seaweed along shore. These small 


\section{2}
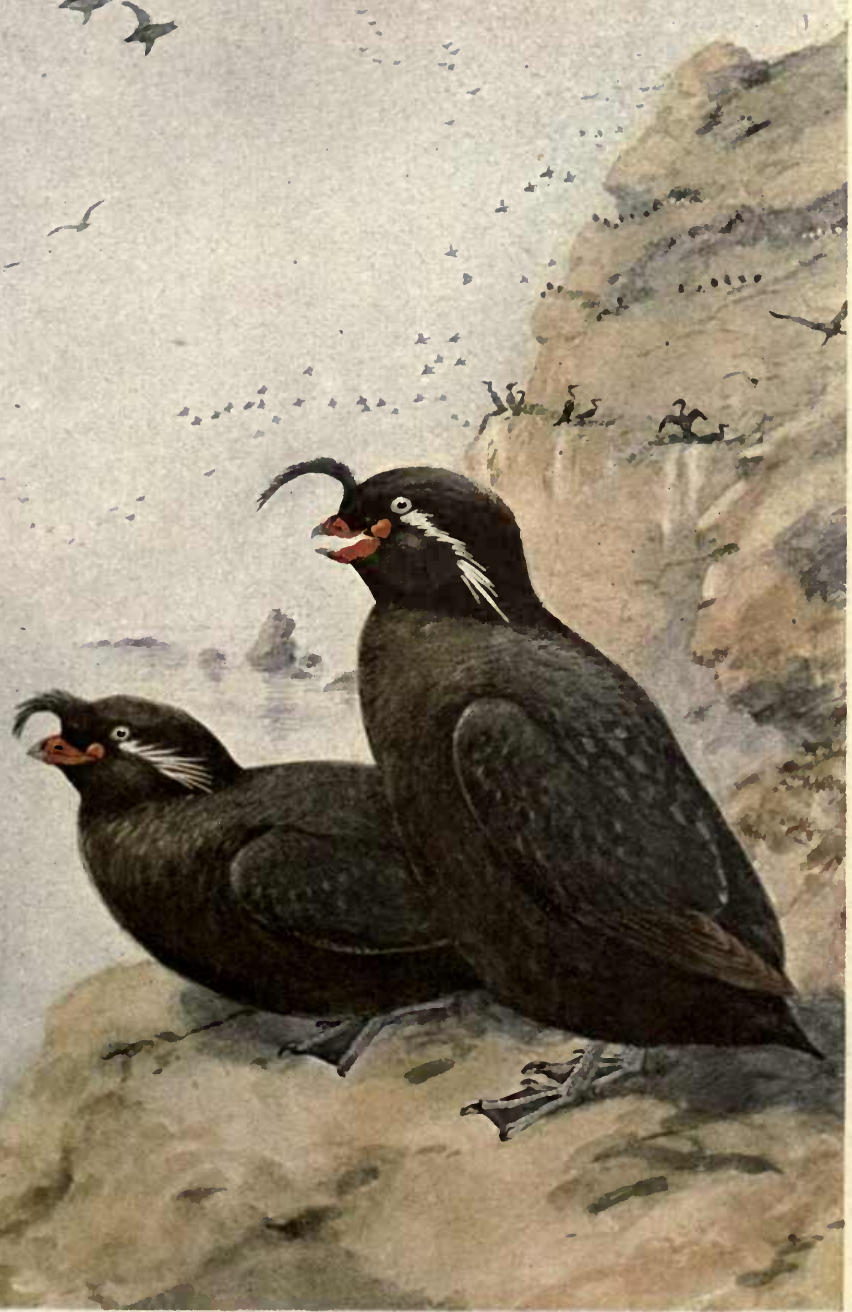

CRESTED AUKLET

Order-PYcopodes

Genus-A sтнIA
Famlly-AlCide

Specles-CRISTATELLA 


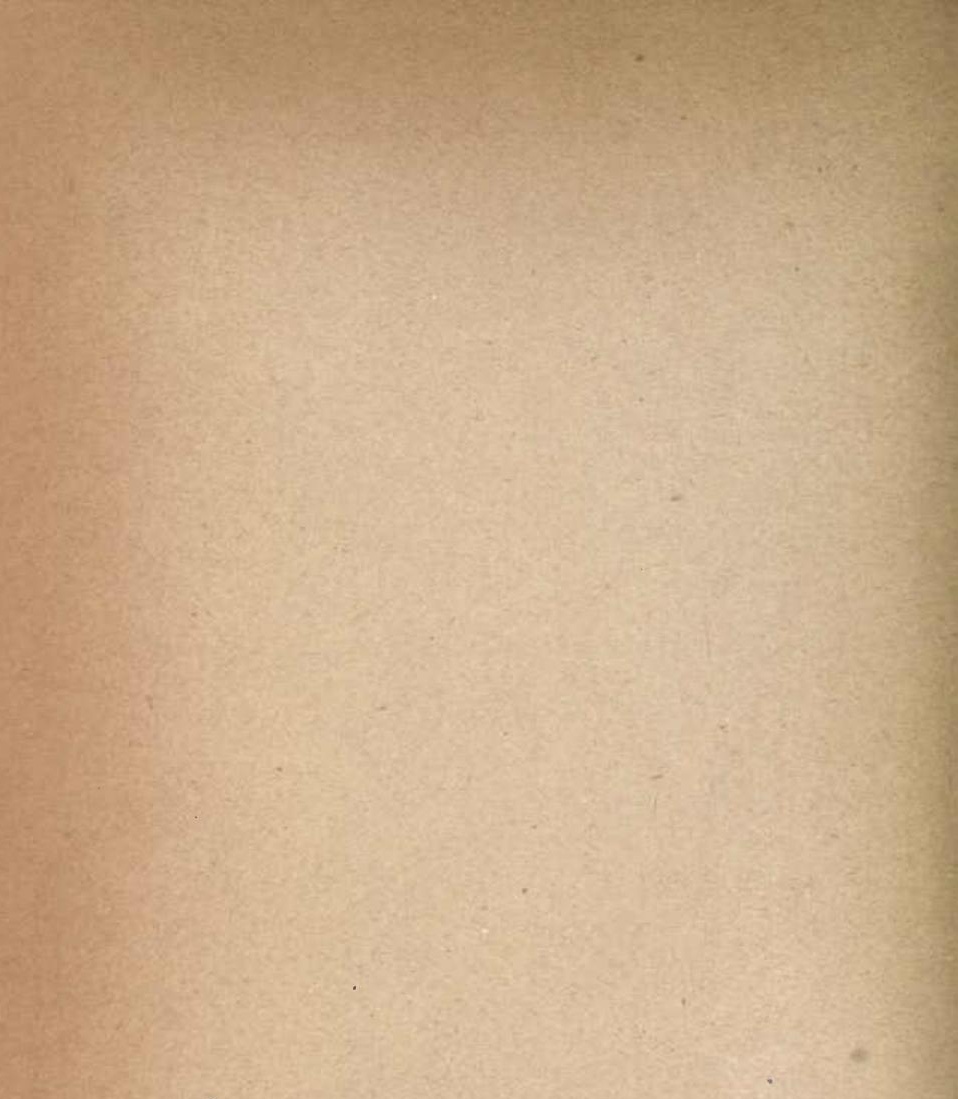


crustaceans, less than a quarter of an inch in length, are amazingly abundant in Alaskan waters and, as a never-failing food-supply, account for the surprising abundance of auklets of all kinds.

The native Aleuts eat auklets, just as they do most other kinds of sea-birds, and capture them with nets that are like a large dip-net with a long handle. The native hunter conceals himself at some point near the beach or bluffs over which the birds are accustomed to fly close. When a flock approaches, the net is swung upward, and a skilful native has little difficulty in

Netting the Auklets catching two or three birds out of each flock that passes. The Aleut people are true children of Nature, and the greater part of their food consists of the fishes, seals, and sea-birds found along their shores. The misty and often stormy coasts would be desolate indeed without the lively presence of auklets; and we cannot help wishing that they abounded in more southern latitudes, where their charming ways could be better known. Some of nature's finest exhibitions of bird-life, however, are arranged without reference to civilized spectators.

The Crested Auklets arrive at the Pribilofs in May, and remain until the winter ice begins to invest the islands, when they go farther south. They are noisy in the breeding season when about their nests, but are rather silent at other times.

While they take alarm and leave the cliffs when closely approached, they have more confidence when on the water, and do not readily dive or take flight except to make way for the boat. About islands where they are not especially abundant they may yet be as thick as bees at some particular cliff, long rows of them lined up on the ledges, while others are coming and going. Sometimes we saw them far off shore in flocks hundreds of yards in extent. They are a plump, well-fed race, and appear to have plenty of time for play, both in the air and on the water.

The Crested Auklet is distinguished by its much larger size from its nearest relatives, the Whiskered and Least Auklets, and by the differently shaped bill and the presence of a recurved crest from the Paroquet Auklet. More-

Distinctive

Features over, the underparts are entirely dark in the Crested Auklet, but largely white in the three allied species.

Males and females are alike in plumage, which is sooty black above, and brownish beneath; but this obscure coloring is relieved by the lively crest, the bright red of the beak, and the white, plume-like feathers which extend downward and backward from the eye. The white iris also contributes to the alert appearance of the bird's head. The feet are bluish, with dark webs. That part of the red beak around the corner of the mouth is soft and flexible.

The forward-curved crest of this auklet, resembling that of the California Quail, suggests the name "Sea-quail," by which it is known to English-speaking persons. The native name "Kanooska" is of Russian origin, and means Little Captain. 

inches.

In length individual birds vary from eight and one-half to nine

The plumage in winter is the same as in summer, but the bill is markedly different. The Crested Auklet not only moults its feathers like other birds, but sheds the red, horny plates about the base of its beak after the breeding season.

The very young bird, whose appearance has not long been known,

\section{Seasonal}

Changes is a ball of smoky down, in no way resembling its parents. In the immature bird the frontal crest and white feathers beneath the eye are wanting, or but slightly developed, while the bill is much smaller and dusky brownish.

At the Pribilofs, it is no uncommon sight to see fur-seals, sea-lions, and many kind of sea-birds, including Crested Auklets, in great abundance within a radius of fifty yards.

We need not concern ourselves, I think, about the preservation of these auklets. They dwell among the high cliffs and boulder-strewn beaches of a thousand uninhabited islands, and know how to stow away their eggs so safely that neither natives nor blue foxes can get them easily.

\section{Classification and Distribution}

The Crested Auklet belongs to the Order Pygopodes, Family Alcida, and Genus Athia. Its scientific name is Ethia cristatclla. It inhabits, all the year round, the coasts and islands of Bering Sea, moving southward in winter to the Aleutian Islands and Japan. 


\title{
THE GREEN HERON
}

\author{
By T. GILBERT PEARSON
}

\section{The National Association of Audubon Societies}

\section{Educational Leaflet No. 66}

The Green Heron is the smallest North American member of that subfamily of birds sometimes called True Herons. The expanse of wings, from tip to tip, of one of ordinary size, is two feet; when the bird stretches its neck to its greatest length the distance from the end of its tail to the point of its bill is seventeen inches: Its legs, like those of all herons, are sufficiently long to enable it to wade in shallow water. These are destitute of feathers along the greater part of their length, a characteristic common to all birds that are in the habit of wading much in the water. The bill

\section{Character-} istics is long, very sharp at the end, and well adapted to seizing slippery prey.

Many species of herons inhabit chiefly extensive marshes, the shores of lakes and large streams, or such vast swamps as exist in the South. The Green Heron, however, does not confine its travels or stoppingplaces to such localities; wherever ponds, creeks, or even smaller streams occur, especially if these be in open country, there you are likely to find this bird. Because of this general distribution, more persons, probably, have a bowing acquaintance with the Green Heron than with any other member of the family.

It is in part nocturnal in its habits, and, in many regions of the United States, it is not uncommon to hear its guttural note when, on still summer nights, it wings its way across the country from one feeding-ground to another. If you chance to be working your way along a creek-bank, you may startle the bird from its roost in the willows, or from a feeding-place among the rushes or tall grass growing in shallow water. On such occasions it will fly away with a startled cry, sometimes passing entirely out of sight; but, if not unduly alarmed, it will often alight on a tree or snag near by, and, with jerking tail and raised crest, survey the intruder with ill-concealed suspicion and disapproval.

The writer well recalls the first Green Heron's nest he ever saw. This was down in the pine-barren region of central Florida. The country there is

The Nest in the Sink-hole largely underlaid with soft limestone, through which innumerable underground streams gurgle along their subterranean courses.

Here and there the rock becomes disintegrated and washed away to such an extent that the earth above gives way and falls into the cavern beneath. Thus are formed the many "natural wells" and "sinkholes" that one finds scattered about the country. In a bush growing from the side of the rock, and hanging over the water in one of these 
sink-holes, a pair of Green Herons, long years ago, built the loose platform of twigs which served them as a nest. Day after day, when I crept cautiously to the brink and looked down, I could see one of them sitting on the green eggs forty feet beneath me. The still water of the sink below the nest was never ruffled by a passing breeze, and from its depths frogs and small turtles climbed to projecting bits of rock, and added touches of life to the weird scene.

A mile away, in a small water-oak growing in an abandoned field, two of us found another nest the succeeding year; possibly it was built by some of the young hatched in the deep shadows of the sink. There was no way to approach this nest without the birds discovering the intruder long before the tree was reached. Twice we

\section{Fear of}

Intruders visited the spot, and each time the parent-bird that was at home departed hastily. It is not good to disturb birds too frequently when they have the care of their eggs or young, so we did not go near the tree again until the young had flown. Although the nest was so frail that one could see the eggs through the twigs from the ground below, it must have been securely built, for much of it was still in position the next spring when we again went to the old field, hoping that the Green Herors might still be using the tree as a nestingplace.

In the edge of the lake, near by, grew thickly clustered many tall buttonwood bushes, in which, each April, were built the nests of a colony of Boat-tailed Grackles-those large, shiny blackbirds common in the far South. One spring a pair of Green Herons made their nest here and, despite the great noise and clatter which always prevails in a blackbird colony, they appeared to find the situation quite to their liking, for later the young were seen with their parents along the shore.

If you should chance some summer to visit the farm of Alden $\mathrm{H}$. Hadley, in Indiana, he would probably take you out to his large apple orchard and show you six or eight nests of the Green Herons. For many years this little colony has gathered there every season when the birds return to the North after the snows have gone. Near by flows a small stream, along which the birds gather their food, chiefly by night. Up and down the stream, across fields and through the woods, the birds follow its winding course, collecting the minnows, frogs, grasshoppers, and various water-insects and crustaceans which they delight to eat.

Perhaps a more striking example of this bird's tendency to rear its young near the abode of man is shown by the fact that for several years

in Pelham Bay Park, within the limits of Greater New Herons in
the City York City, a little colony of four or five pairs have selected an old apple-orchard in which to make their nests and hatch their young.

Thus we may see that the Green Heron has a wide range of suitable places to choose from for nest-building. Often the nest is far from any pond or lake, and frequently it is found singly, with no other heron's nest near. Yet this is by no means always the case. Go to the great 


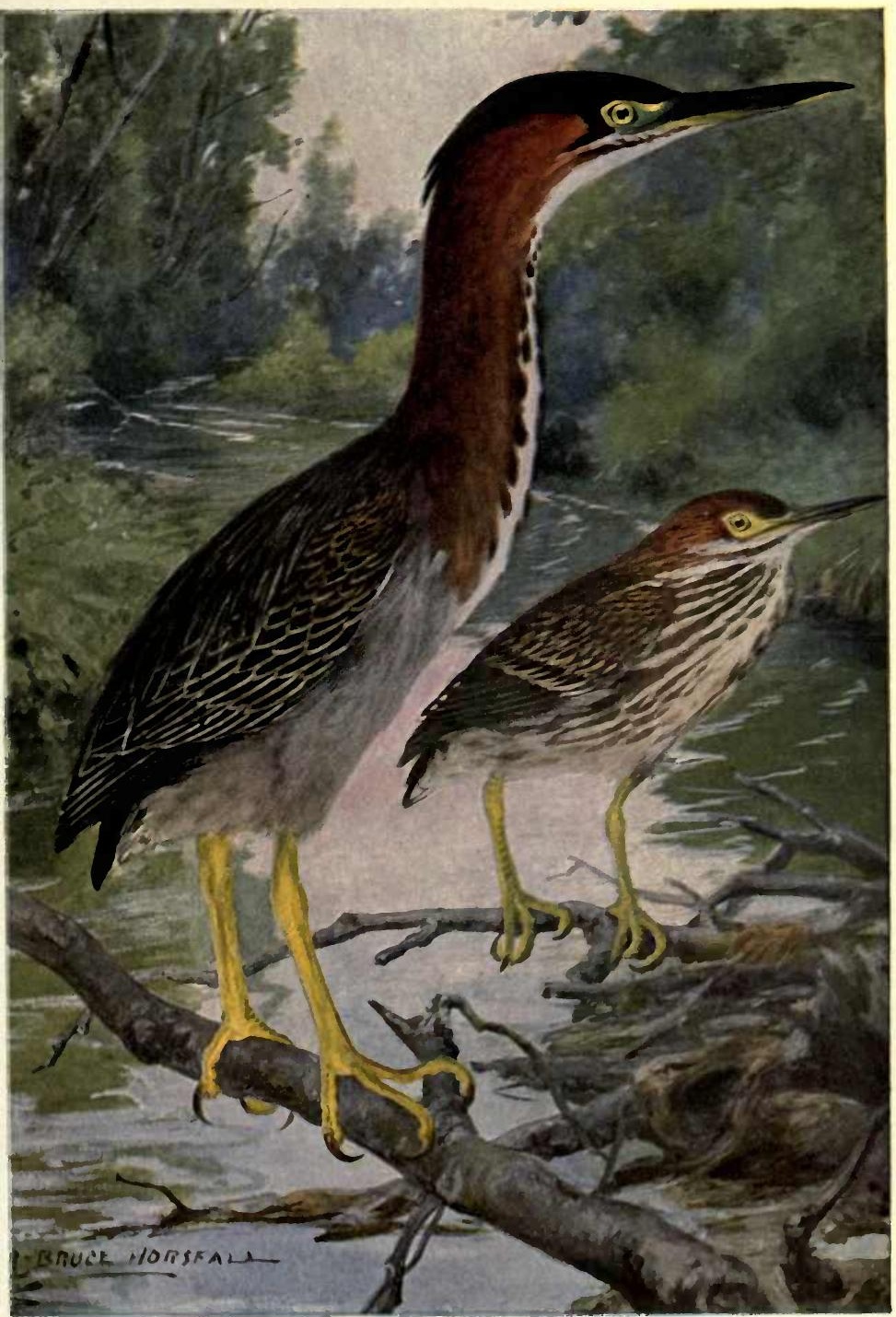

GREEN HERON

Order-HERODIONES

Genus-Butorides

Family-ARdeIde

Species-Virescians

Natlonal Association of Audubon Societles 

colonies of nesting herons and ibises in the southern swamps, and among the hundreds or often thousands of birds collected there you will find now and then a nest of the modest little Green Heron, occupying some inconspicuous spot in one of the willow-trees or cypresses.

Every bird in the world, as probably every other wild creature, has its natural enemies. Something is ever on the alert to prey upon it. Every sparrow, wren, warbler, thrush, hawk, and even the resourceful and powerful eagle, must keep a sharp lookout that some foe does not catch it or destroy its eggs and young. The Green Heron is no exception to this rule.

Vigilance

Necessary Foxes, also minks and weasels, possibly catch this bird now and then.

The nesting-season, however, must be the period of greatest anxiety for this bird and for all others. Although the cradle for the eggs is always well hidden in the rushes or among the foliage of bushes and trees, it is, nevertheless, often discovered by sharp-eyed wild hunters when out in search of good things to eat. Crows, which know so well how to look out for their own interests, every year steal Green Herons' eggs from the nests. The Fish Crow, which is slightly smaller than the Crow that is commonly seen, and is particularly numerous along the seacoast, and also haunts the neighborhood of large inland ponds, lakes and rivers, is a wonderfully successful egg-hunter. When one of these robbers goes out for an omelet, it flies across the country or slips through the trees in a most crafty and silent manner. Finding a Heron's nest, it will cunningly withdraw, and return at a time when the parent-bird is temporarily away, taking a rest or looking for food. Then comes the Crow. With a strong, plunging stroke it will drive its bill into an egg, and fly off with it without a sound. Often it will alight on the limb of some tree near by and proceed at once to enjoy its repast, but sometimes will fly a long distance with its booty before stopping to devour it in seclusion.

Once I saw a plucky Kingbird attack a Crow which was carrying on its bill a Green Heron's egg. The fierce little black fighter boldly attacked the marauder, which was many times its size, and drove it for fully a quarter of a mile. The Crow flew with all its power in its efforts to get away from its tormentor. The Kingbird followed fast, and frequently ranging above it would dart down at the head and back of the Crow. In desperation, the egg-hunter finally dropped its load, and at length escaped to the friendly shelter of a thick pine tree. The egg chanced to fall into a pool of water, and I picked it up unbroken. In one side was a hole about the size of the end of a man's finger. This had been made by the bill of the feathered robber.

When the Green Heron builds its nest in bushes growing over or near the surface of a pond or lake

Danger from Snakes

there is always danger from water-moccasins, which are very fond of birds' eggs.

It is a well-understood fact that many more of these interesting birds would be seen if they were not so constantly persecuted by their 
human neighbors. Green Herons sometimes come to ponds where fish are being propagated, and cause the owners annoyance by eating many of the young that have been hatched and are being raised with so much care. This very naturally causes the fish-breeder to become worried, and sometimes he gets his gun and shoots the birds. From the data which have been carefully gathered we now believe that Green Herons, as a whole, do comparatively little damage, but that, on the other hand, they may render mankind a distinct service. Quite apart from seeking revenge from any real injury they may do about fish-ponds, many men shoot them whenever they get the opportunity for the mere pleasure of seeing whether they can hit them; and thoughtless and ill-trained boys have been known to kill these trusting birds with little rifles, all of which is wrong.

\section{Evil of \\ Birds'-nesting}

Another influence which has tended to decrease their this pursuit; and so extensively has the practice been carried on that Green Herons, as well as other birds of certain regions, have been largely depleted in numbers. Collecting eggs should never be indulged in except by persons whose knowledge and real scientific purpose warrant the State authorities in granting them a license for the purpose. Even then, the collecting should not be carried on to an extent which will be appreciably injurious to the well-being of the birds.

In most of the States in the Union it is now against the law to kill Green Herons except under permits granted by the State authorities, and all right-minded persons should unite in giving these statutes their most hearty support.

\section{Classification and Distribution}

The Green Heron is classified as belonging to the Order Herodiones, the Suborder Herodii, Family Ardeida, and the Subfamily Ardeinc. It is found in suitable localities from Oregon and Ontario southward to the West Indies and Venezuela. Besides the eastern form, to which this leaflet especially refers, two geographical races or subspecies are recognized by ornithologists: viz., Frazar's Green Heron (B. v. frazari), a slightly larger, darker form in Lower California, and Anthony's Green Heron (B. v. anthonyi), a pale desert-race in northern California and southward through arid Mexico.

This and other Educational Leaflets are for sale, at 5 cents each, by the National Association of Audubon Societies, 1974 Broadway, New York City. Lists given on request. 


\section{THE ALASKA LONGSPUR}

By EDWARD W. NELSON

\section{The National Association of Audubon Societies}

\section{Educational Léaflet No. 67}

The Alaska Longspur is the western variety of the Lapland Longspur, distinguished from the normal eastern longspurs by the comparative paleness of its colors. The Lapland Longspur is a bunting closely related to the Snowflake, and one of a genus remarkable, as its name indicates, for the great length of the claw of the hind toe, which is as long as the toe itself. The home of the species is in high northern latitudes, extending around the whole circle of the polar sea, these buntings frequenting in summer the most northerly coasts and islands of Siberia and Europe, as well as Iceland, Greenland, and the shores and islands of Arctic America.

Home of

Longspurs

West of the Mackenzie River the Alaskan, or pale, race of this longspur is extremely abundant and familiar in summer all over the tundra, or treeless coast-barren, and on islands in Bering Sea; and it breeds throughout the coastal region from Kadiak Island to the Arctic Ocean.

The males reach Dawson, on the upper Yukon, from the south, between the $5^{\text {th }}$ and 18 th of April, in nearly perfect breeding-plumage. About the end of April they arrive at St. Michael, on the coast of Bering Sea, and are known to reach southern Greenland about the same time. Murdock tells us that they are abundant in summer at Point Barrow, where they arrive about May 20. The first eggs are laid there by the beginning of June, and the birds begin to migrate southward at the end of August or early in September. On the western Aleutian Islands, Dall found them to be abundant summer residents, and discovered a nest with four much-incubated eggs on June 18 . They leave these islands in winter; and I may add that I do not know of a winter record from any part of Alaska.

During the summer of 1881 , I found them nesting on St. Lawrence Island, in Bering Sea, and on both sides of Bering Strait, but saw no trace of them on either Wrangel or Herald islands. They are well known and abundant on the Fur Seal Islands, where they are the most beautiful songsters among the limited number of land-birds summering there. They winter through-

Arctic

Songsters out north-central Europe and middle Asia eastward of Japan, and in the northern United States, mainly from the Great Lakes to Oregon and Washington, but sometimes as far south as Texas.

Early in May, the tundra on the Alaskan coast of Bering Sea is still mostly covered with snow, except in grassy spots on southern exposures and in other favorably situated places. Here the first male longspurs 
suddenly appear in all the gaiety of their summer dress. At this season, the males are beautiful, the head and breast being jet-black with white or buffy stripes behind the eyes, the back of the neck bright rufous, and the back streaked with black and brownish. These birds appear not to undergo a spring molt, but to attain the breeding-dress by the wearing away of the light edgings of feathers characteristic of the winter plumage; at the same time the remaining parts of the feathers appear to become

\section{A Gay}

Costume brighter and richer, as though suffused with added ccloring matter. There is considerable individual variation in color, due to a greater or less intensity rather than to any change in pattern.

The females, as usual among birds, are more obscurely marked, and reach the breeding-ground a little later than the males. They arrive on the coast of Norton Sound in flocks and spread rapidly over their breeding-ground.

Despite the bleak surroundings and chilling winds, the longspurs soon become abundant, and by the middle of May are in full song. As if conscious of their handsome appearance, the males choose to sit on the tops of projecting tussocks, rocks, or small knolls, the only breaks in the monotonous surface, where their bright colors render them conspicuous.

The Lapland Longspur is one of the few birds, which, like the Skylark and the Bobolink, is so filled with the ecstasy of life in spring that it must mount into the air to pour forth its joy in exquisite song. The males are scattered here and there over the tundra on their chosen projecting points, and at frequent intervals mount slowly on

Song-

Flight tremulous wings ten or fifteen yards into the air. There they pause a moment and then, with wings up-pointed, forming $V$-shaped hyures, they float gently back to their perches, uttering, as they sink, their liquid notes, which fall in tinkling succession on the ear. It is an exquisite, slightly jingling melody, with much less power than, but resembling the song of the Bobolink. It has more melody than the song of that bird, and is so filled with the joyous charm of springtime that no one can hear it unmoved. The period of song ends soon after the first of June, when brooding has begun.

By the end of May each songster has found himself a mate, and together they build a snug home, placed on the ground, and as cleverly hidden as circumstances permit. The nests are usually to be found in the driest parts of the tundra, in a hummock, a tuft of grass, or perhaps in a little bunch of dwarf willow; and near St. Michael, in the proper season, one cannot search about for half an hour without discovering several. As one approaches a nest the female usually flutters

Nesting

Habits

off at one's feet, and is immediately joined by the male. Both hover about or fly restlessly from tussock to tussock, uttering protests at the intruder as long as he remains in the vicinity.

Whenever the eggs are nearly ready to hatch, the female shows the greatest solicitude, and when the young appear, her anxiety is still 


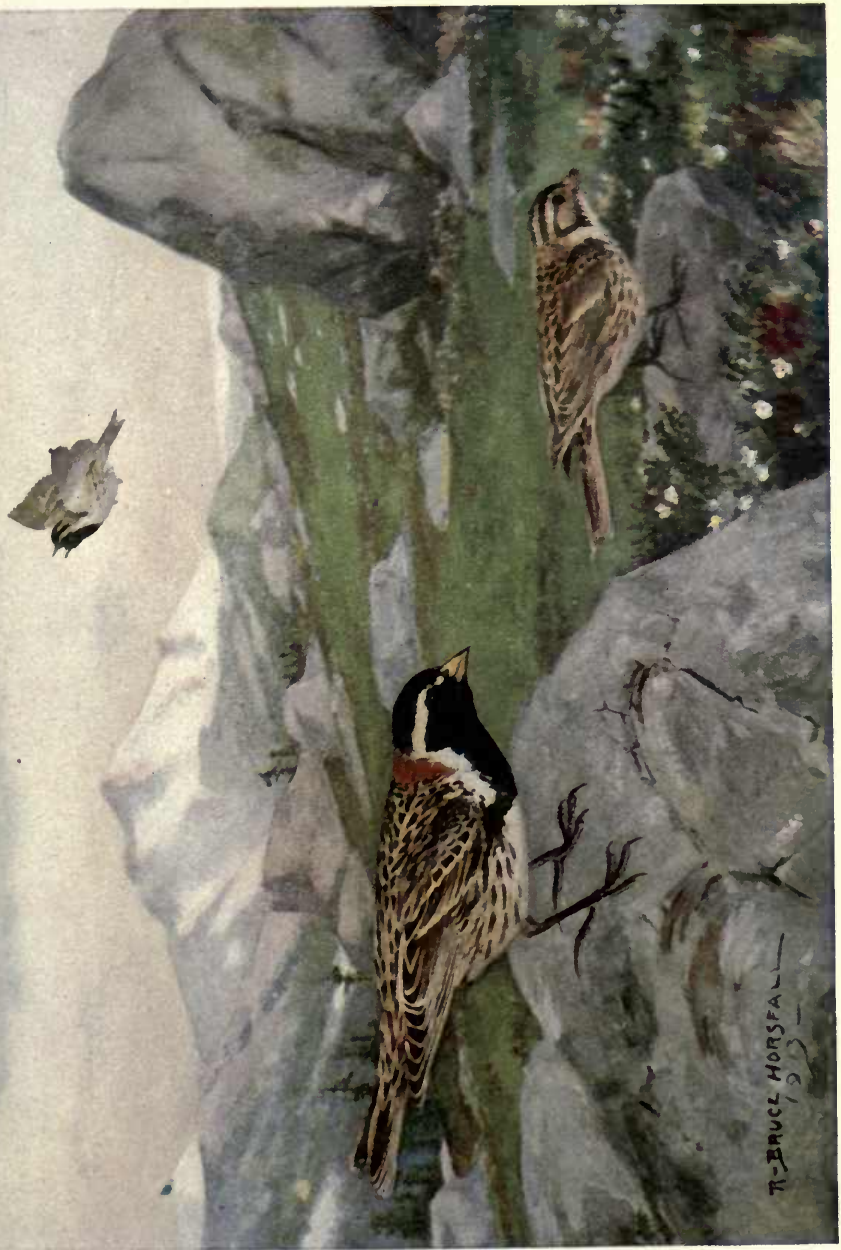

$c$ 
5.
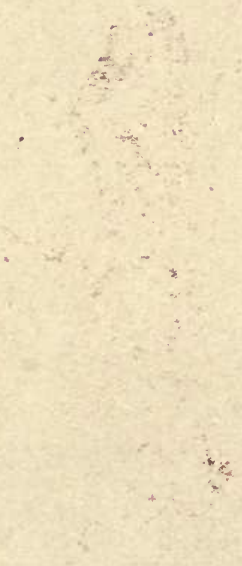
more pronounced. In one instance, the female was frightened from her eggs just as they were about to hatch, and ran along the ground a few yards, uttering a plaintive chee-chee-chee in a fine, vibrating, metallic tone, dragging her outspread wings and tail on the ground, and fluttering as if in mortal agony.

The nests vary in size, but average about two and three-fourths inches in depth by five inches across the top on the outside, and the central cavity is about two inches deep and three inches across the top. The walls are sometimes thick and strong, composed of an abundance of material, but may be a mere cup-shaped shell, barely sufficient to hold the eggs. In most cases they are composed of rather coarse grass, sometimes with moss interwoven, forming a thick layer that frequently is as thoroughly water-soaked as a wet sponge. In a damp situation much more material is used than on a dryer spot; but the interior invariably contains fine, soft, yellow blades of last year's grasses, sometimes mixed with feathers of ptarmigans

\section{Situation}

of Nest

and other wild birds. One that I examined had a thick lining of feathers and dogs' hair.

The eggs number from four to seven, and are heavily covered with blotches and zigzag lines of various shades of brown, and the groundcolor, when visible, is greenish clay-color.

The young are out on the wing sometimes as early as the first of July, but more usually about the tenth of this month, after which they unite in small bands, and are seen about the trading-posts and native villages, where they are heedless of the presence of people, and are nearly as familiar as the English Sparrows in our cities. They remain in great abundance until the last of August or first of September, when they begin their straggling departure. By the first of October, the last one has passed away toward the south, and none are seen until returning spring brings them north again.

They usually begin to move southward before they have fully molted, so that only the comparatively few individuals that have completed the molt in September are found in perfect winter dress on their northern breeding-grounds. The serial changes of plumage as summer advances are worthy of note.

By the first of July, as a rule, the partly fledged birds have the feathers of the crown, back, rump, breast, and throat marked with black or very dark-brown shaft-lines, which vary from one-third to one-half the width of the feather. The feathers of the crown and back are edged with a dingy, yellowish buff; those on the nape, with grayish or dull ashy. The edges of the breast-feathers are soiled yellowish, with a wash of the same on the Autumn
Plumage ieathers of the entire undersurface. There are two indistinct white wing-bars. This state of plumage is hardly attained before it begins to give place to the fall-and-winter clress with which we are familiar, when the birds come trooping down to the United States from the North at the beginning of winter. Beginning on the lower and cauclal parts, 
the feathers are gradually molted and replaced, the change extending slowly toward the bill.

In winter and early spring Alaska Longspurs are very common in the open country along the Canadian boundary and throughout North Dakota and Montana, and thence west to Oregon and Washington. A vivid idea of the vast number of these birds in the aggregate is given by Dr. T. S. Roberts, in The Auk for 1907, in his account of the enormous number which perished during a storm in northwestern Iowa and southwestern Minnesota on the nights of March I3 and I4, 1904. In two square miles of icy surface on two small lakes, Dr. Roberts thinks nearly a million birds

\section{Perishing of Cold} lay dead, and he estimates that in the vicinity probably a million and a half birds perished that night. These birds had been caught in a storm of wet snow while migrating and, as the total area over which their bodies lay scattered exceeded 1,500 square miles, it is evident that the number killed must have been many millions. Such catastronhies must occasionally overtake birds like these, which live on open shelterless plains and exist so closely on the borders of winter. The wide extent of their breeding and wintering grounds, however, insures them against any serious danger to the species from local causes, no matter how destructive these may be.

\section{Classification and Distribution}

The Alaska Longspur belongs to the Order Passeres, Family Fringillida and Genus Calcarius. Its scientific name is Calcarius lapponicus alascensis. It ranges and breeds throughout Northwestern America from the Mackenzie River westward to the islands in Bering Sea, and winters among the foothills of the eastern slope of the Rocky Mountains from Oregon to southern Colorado. 


\section{THE BROWN THRASHER}

By T. GILBERT PEARSON

\section{The National Association of Audubon Societies Educational Leaflet No. 68}

Among the twelve hundred and more species and varieties of wild birds found in North America, a certain number are so well known that few persons have not made their acquaintance either by actual introduction or by hearsay. The Robin, the Crow, the Jay, and the Eagle, for example, are household words, often familiar to children long before the little folk are large enough to go afield and observe the birds for themselves. The writers of verse have done much to make some of our feathered friends known to us. In fact, poets have depicted the charms of some birds in such living, melodious verse that it is doubiful whether the fame

The Birds
and
the Poets of these birds would ever fade from the memory of mankind, even should the species thus glorified pass for all time from our view.

Many of us, when children, read certain pleasant lines upon the Brown Thrasher. The schoolbook called it "Brown Thrush," and perhaps the name does quite as well. The poem to which I refer is truly a beautiful one, and should be memorized by every child who does not already know it, especially as it speaks the creed of the Audubon Society.

There's a merry Brown Thrush sitting up in the tree;

He's singing to me! he's singing to me!

And what does he say, little girl, little boy,

"Oh, the world's running over with joy!

Don't you hear? don't you see?

Hush! look in my tree!

For I am as happy as happy can be."

And the Brown Thrush keeps singing, "A nest do you see?

And five eggs hid by me in the juniper-tree?

Don't meddle, don't touch, little girl, little boy,

Or the world will lose some of its joy.

Now I'm glad! now I'm free!

And I always shall be,

If you never bring sorrow to me."

The Brown Thrasher well deserves the fame which it has achieved as a vocalist, and fortunate is the man whose garden a pair of these birds choose for their abode. Its song is the most varied contribution to the bird-chorus heard at daybreak in the Northern States; it is the Mockingbird of the North-so much, indeed, does its song suggest the musical performances of that masterly vocalist that early American ornithologists often called it the "Ferruginous Mockingbird."

The Thrasher, while singing, usually occupies the topmost bough of some bush or tree, and, although it sings mostly in the morning, occasionally it may be heard at any hour of the day. Its voice is loud, clear, 
and far-reaching, but hardly possesses the sweetness of tone so characteristic of the Wood Thrush and the Veery. The bird's fame is based

A Varied Song rather on the wide variety and clearness of the notes it produces, aided perhaps by the fact that it sings much of the time within sight and hearing of our garden-walks and house-windows.

Upon arriving in the spring from his winter home in the Southern States, this bird usually announces nis presence by a voluble song, with which he floods the morning air from his perch on a neighboring tree. The worry and responsibility of domestic life which shortly come upon him, in common with many other singing birds, do not, to any notable extent, lessen the force or frequency of his music.

The nest of the Brown Thrasher is, for the size of the bird, a rather bulky structure. It is composed mainly of dead twigs, and has a lining of rootlets. This nest is usually placed in a bush or thick cluster of vines, where it is well concealed from the eye of anyone passing. I recall finding a nest in the main fork of an old pear-tree about three feet from the ground, and another situated on a small stump, and well screened from view by the sprouts which had grown up above it. Occasionally the nest is even placed on the ground, always well The Nest hidden by vegetation; and observers have recorded that they have seen ground-built nests made in situations so wet that the dampness, working up through the nesting-material, caused the eggs to addle. The parent-birds, failing to recognize the misfortune which had come to their treasures in some such instances, continued to sit on them for several weeks.

The eggs, which are usually four in number, are thickly and uniformly covered with fine dots of cinnamon or rufous brown.

When one approaches the nest of the Crow, if one of the birds is at home, it will usually leave, and will frequently not again be observed until the intruder has left the neighborhood, and some other birds have this habit of deserting their nest on the approach of real or imaginary danger. This, however, is not the case with the Brown Thrasher. When an enemy approaches both birds instantly become alert, or if one chances to be away the scolding notes of the one on guard soon recall the absent companion. Together they fly in and out of the bushes, constantly voicing their alarm and disapproval, and often darting viciously at the creature which has trespassed upon their privacy. They Habits become especially excited and annoyed upon the appearance of that most dreaded of all birds' enemies -the house-cat; and their alarm is not without reason, for seldom is a Thrasher's nest built in such a situation as to be safe from the agile activities of this marauder.

One of the saddest sights in the bird-world is to witness the dejected movements, and hear the piteously mournful notes, of a pair of Brown Thrashers whose nest has been despoiled by Grimalkin. 


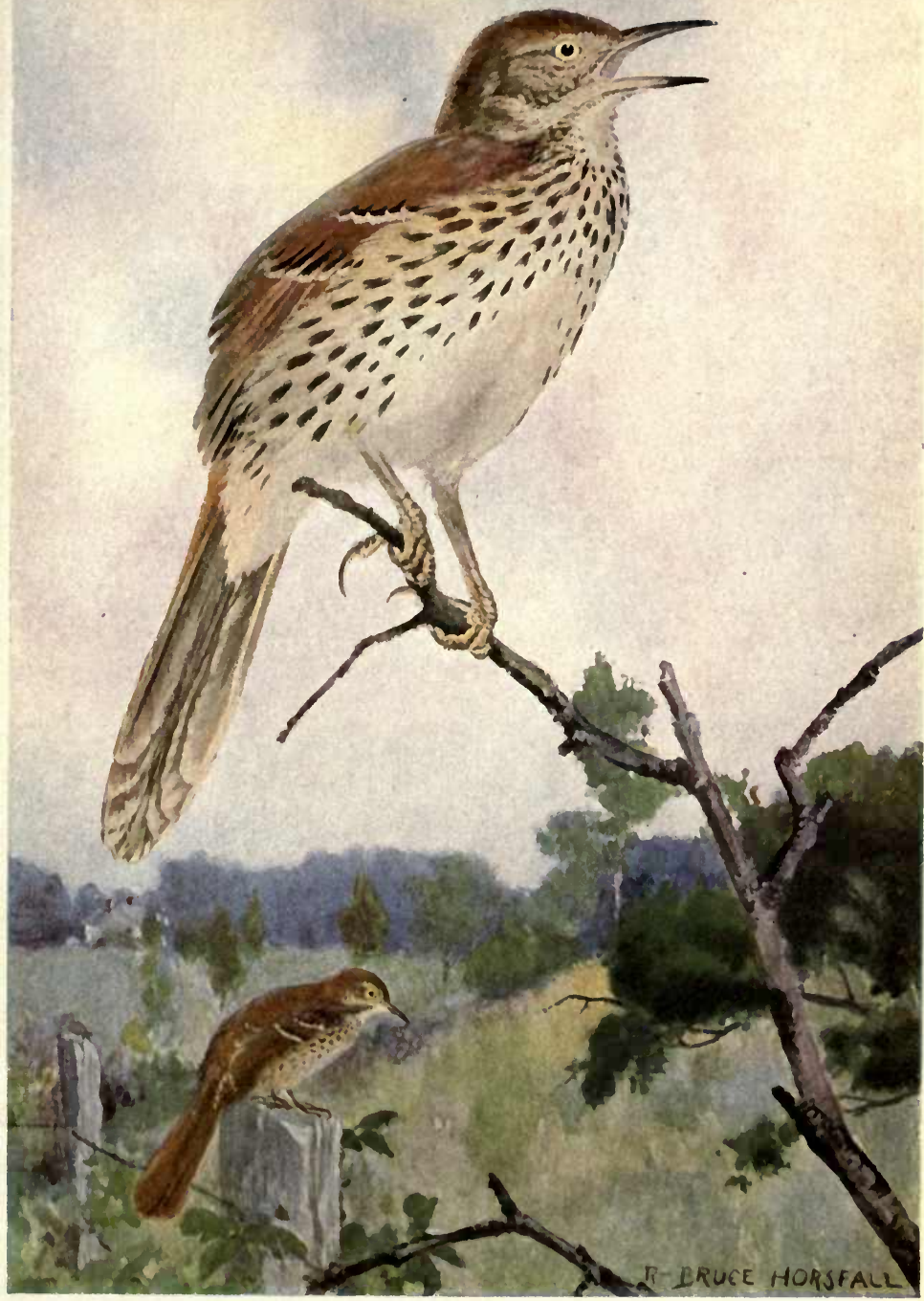

BROWN THRASHER

Order-PASSERES

Famlly - M 1 MID

Genus-Toxostoma

Specles-RuFum

National Assoclation of Audubon Socletina 

Some years ago a pair of these birds constructed their home in a thorn-busl growing on the lawn of a residence where the writer chanced to be visiting. The members of the household became much interested in watching the fortunes of this bird-family, and especially were we impressed with the frequency with which the parents fed their young. At this work

A Nest on the Lawn they were busy all day long. The birds seemed to gather food for the little ones entirely from the lawn of the adjacent residence and from the two gardens in the rear, rarely going off this territory.

In approaching the nest they would advance flying low over the grass until within about ten feet of the thorn-bush. Alighting on the ground, they would look around for a moment, to see if any danger was near, and then hop rapidly along to the lower branches, which came down to the ground; then from limb to limb they would jump, ascending a sort of irregular stairway to the nest, when we could hear the eager clamor of the four little ones as they received their nourishment. We soon noticed that one bird always went up the right-hand side of the bush, and the other invariably hopped up through the limbs on the left side.

I became curious to know just how often they brought food, and one morning, with notebook in hand, sat for an hour on the veranda watching the movements of our little brown neighbors. Through my fieldglass I could see that they brought one, and at times apparently two or three, insects or their larvæ in each trip. Every time a bird came to the nest I made a mark with my pencil. In the middle of the day I made the same observations for an hour, and repeated the records in the evening.

The bird which went up the right-hand side of the bush made a trip on an average of every two and a half minutes, and the bird which went up the left-hand side made a trip every ten minutes. The young were kept at home in the nest about two weeks. If the birds took only one insect a trip, it would mean that during this interval these Brown Thrashers fed to 50,000 Insects their young 5,180 soft-bodied worms and insects. This, of course, does not take into consideration what the old birds ate during this time; nor what they consumed during the period of incubation; nor all those delectable morsels which the male fed to the female during the blissful days of courtship. If we include all these, and also what the family of six ate after the young had left the nest and flown off into the bushes, it is most conservative to estimate that this pair of Brown Thrashers and their young were responsible, that summer, for the destruction of the lives of over fifty thousand insects, most of which were injurious to the vegetation of the region.

Some birds are of so great value to men that. even if there were no laws on the statute-books to protect them, every man, woman, anil child of the entire countrv should use their utmost influence to see that these birds are not killed by human enemies. and that. so far as possible. they receive strict protection against cats and other animals. Few birds 
are of more service to us than is the Brown Thrasher, yet, despite this fact, they are frequently shot.

Such an instance arose in connection with the pair of Brown Thrashers mentioned above. One day I heard the report of a little rifle and, looking out of the window, saw that a boy had just fired at one of the birds. By the time I was able to reach the lawn he was taking aim for a second time. I shouted to him to stop, and, running out to the road, told him he must not kill those birds-not only because we wanted them to live, but because it was against the law to shoot them. His father, who had accompanied his twelve-year-old boy on his walk. came up and asked for an explanation of my conduct in interfering with his son. In defense of the young hunter the father declared: "I have bought my boy a rifle and am teaching him to shoot. I want him

Misguided Sport

to grow up and be a sportsman. Why do you interfere with him in his innocent sport?"

In the days when the father was a boy there were, unfortunately, no Audubon Societies in the country, and comparatively little instruction was given in the schools as to the economic value of wild birds, and the desirability of preserving them. Still, it seemed incredible that this man who, from his appearance, had evidently prospered in business or by inheritance, should have lived to the age of fifty and never learned better than to think that the greatest service which a Brown Thrasher can render is to serve as a target for a boy who is ambitious to learn the art of skilfully pursuing and destroying wild life.

Occasionally we hear complaints that the Brown Thrashers destroy grain and fruit. However, after careful and extended observations, bird-experts of the United States Department of Agriculture have reported that 65 per cent. of the bird's food consists of insects, mainly beetles. The fruit which they eat is mostly of wild shrubs, and the damage done to cultivated fruit is exceedingly small. The grain taken appears to be entirely waste kernels scattered in harvesting or in hauling it along the roads.

\section{Classification and Distribution}

The Brown Thrasher belongs to the Order Passeres, Suborder Oscines and Family Mimidce. Its scientific name is Toxostoma rufum. It breeds from southern Alberta, southern Manitoba, northern Michigan, southern Ontario and nort'l rn Maine, southward to the Gulf of Mexico, and westward to the base of the Rocky Mountains; and winters from southeastern Missouri and North Carolina to southcentral Texas and southern Florida. In the Southwestern States it is replaced by several other species of the same genus.

This and other Educational Leaflets are for sale, at 5 cents each, by the National Association of Audubon Societies, 1974 Broadway, New York City. Lists given on request. 


\title{
THE TUFTED PUFFIN
}

\author{
BY WILLIAM LEON DAWSON
}

\section{The National Association of Audubon Societies}

Educational Leaflet No. 69

To those who have been fortunate enough to visit some romantic isle off the North Pacific shore, these quaint fowls make an irresistible appeal. "Sea Parrots" and "Jew Ducks," the sailors call them; and we should all be inclined to poke fun at them for therr outlandish head-gear if the situation were not so perfectly redeemed by the dignified behavior of the birds. Masks are essentially ridiculous; but these "Masking Puffins" will not countenance laughter, and the grave solemnity of their regard brings you soon to respect, and then to admiration. For my own part, I confess a positive affection for these droll Quakers of the sea.

Puffins, in common with other species of the Auk family, spend the winter upon the ocean, and are seen near land only when the buffeting of some storm of unusual severity strews the sand with their dead and wounded. As

\section{Nuptial Ornaments} spring advances, these birds are provided with an extraordinary array of nuptial ornaments and appendages. Males and females alike acquire, in place of dull black feathers, a white facial mask; and this is prolonged behind from either side into long, waving feather-"horns" of a rich, deep straw-color. The eyelid becomes brilliant red; and the great red beak, always stout and strongly compressed, is further augmented basally by a new set of horny plates of a dull olive-green or delicate corn-color, and these, in turn, exactly match the irides in tint. The feet also become bright vermilion, instead of a pale salmon.

Thus gaily caparisoned, the Tufted Puffins repair to the grassy, sloping hillsides of the rocky islets which constitute their summer homes, and proceed to renovate the old nesting-burrows, or else dig new ones. They work intermittently at this. Stejneger, on the Commander Islands, noted that in the early days of the season the Puffins spent only one day ashore in alternation with two days at sea. It is probable, therefore, that the birds engage in the evolutions of courtship during these "sea-days." for I have never

\section{Demure \\ Behavior} seen anything but the most circumspect behavior when they were ashore.

It is difficult to exaggerate the gravity of these tranquil birds, absolutely silent on all occasions save when caught and harassed, when they may emit a low, raucous groan. They spend much time standing demurely at the entrances of their burrows, and the nearest approach to levity one 
ever sees is the accidental shaking of the pendent plumes when the bird turns its head.

If a hillside colony is approached suddenly from shore, the standing population, presumably males, pitches downward to sea by a common impulse; while the occupants of nests come shelling out by twos and threes and dozens, as one traverses the honey-combed earth. Once a-wing, the Puffin returns again and again to satisfy his curiosity, flying in great horizontal circles. There is something weird and funereal about the whole performance!

Later the Puffins settle upon the surface of the water until the sea is black with them. Each bird dives, if only for a moment, upon the instant $\begin{array}{cl}\text { Diving } & \text { of alighting; and it may be that they find it difficult } \\ \text { and } & \text { to effect this exchange of medium without a spill. }\end{array}$ Balancing

Rising also requires an effort, desperate if the sea is smooth, but easier in proportion to the increasing strength of the wind. Once the intruder has left, or has secreted himself, the Puffins return rapidly to reclaim the cooling egg, or to take up the sober vigil at the burrow's mouth. Each alights with uplifted wings held well back. The wings are also lifted from time to time as if to rest them, and they are brought into requisition as balancers whenever the bird attempts to walk. Be the going ever so easy, the Puffin shifts about as gingerly as a slack-wire performer.

A Puffin's bill is so remarkable a creation that a glance at its structure may not be out of place; though as to what may be the necessity of this powerful crushing organ we are frankly ignorant. The bird is not a shallow-water feeder, and so has no need to crush bivavles. Moreover, in the breeding season it seems to subsist upon small fish,

\section{Food} which are as easily taken by the slender-billed Murre; and, if the bill were designed to cope with some stubborn viand of the middle sea, why reduce its size in winter? We do not know. But we do know that the Puffin's bill is wonderfully contrived of some eighteen plates (with underlying membranes), and that of these, sixteen, including "rosettes, lamellæ and selvedges," but chiefly the olivegreen basal plates, fall away at the end of the breeding season. Their place is taken partly by underlying feathered tracts, and partly by an underlying horny plate deep brown in color; and the basal dimensions of the bill are much reduced. Accompanying these changes, the white facial mask with its plumes disappears, and the entire head becomes uniformly blackish.

A forty-five-degree slope of soil is the characteristic nesting-site of the Tufted Puffin. Here tunnels are driven at random to a depth of three or four feet, and so close together that once, on Erin, one of the Olym-

Nesting

Burrows

hands the entrances of twenty-five others, apparently occupied. This may have been an unusually populous section, but, if we reckoned at half that rate, an acre of ground would carry 2,700 burrows. 


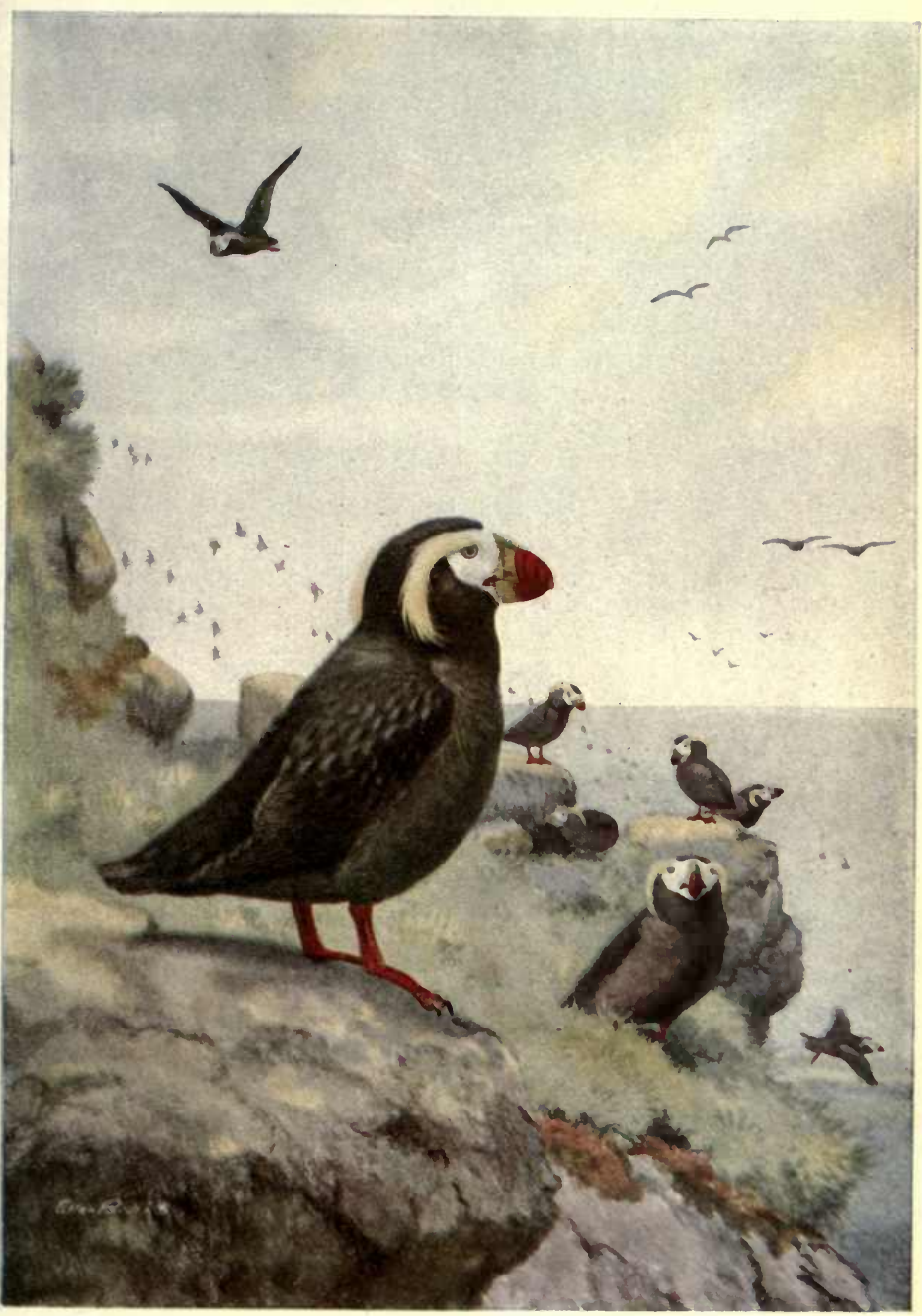

TUFTED PUFFII

Order-PYGOPODES

Genus-LUNDA
Family-ALCIDA

Specles-CIRRHATA

National Association of Audubon Socleties 



\section{The Tufted Puffin}

Hard or rocky soil is not shunned in prosperous colonies, but many efforts here are baffled outright, and "prospects" are at least as numerous as occupied burrows. Elsewhere the top soil on precipitous, clinging ledges may be utilized, or else crannies, crevices, and rock-hewn chambers. Upon the Farallone Islands, California, these birds have little opportunity for digging in the earth, and little necessity for providing fresh burrows, for crevices and cubby-holes abound. These are, for the most part, ample and substantial, and most of them doubtless have seen use measured by cycles rather than by generations. Many eggs, and sitting birds as well, are visible from the outside; while some of the nesting-sites are nothing more than the innermost recesses of niches and caves occupied by Murres.

\section{Homes among Rocks}

On the Farallones, there is a fierce, albeit silent, competition - between these silent birds and the rabbits which swarm over the rocks. I have seen impulsive bunnies which, fleeing from fancied danger, and taking refuge in the first burrow at hand, emerged more hastily than they went in. The Tufted Puffin is a dangerous, as well as a determined foe, and a bite from that rugged beak will cut to the bone.

Although equipped with so formidable a weapon, the birds, in digging their burrows, appear to depend upon their feet. These are provided with nails as sharp as tacks, and the "finish" of the nesting-chamber usually exhibits a criss-cross pattern of fine lines.

Long grass and dense thickets, as of salal, salmon-berry bushes, or dwarf spruce, occasionally afford refuge to birds hard-pressed for room. Here the Puffin, starting from some exposed edge, drives a tunnel through the matted vegetation and deposits its egg upon the surface of the ground, in shade almost as intense as that afforded by the earth itself.

Only one egg is laid, dull white with faint vermiculations of brown and purplish. Because the nest-lining is usually of the scantiest, a few salal leaves or bits of grass, the egg is often so soiled by contact with the earth as to pass for dingy brown.

The baby Puffin is your true Puffin, and it is undoubtedly he who gave this trivial name to the group. He is, indeed, a mere puff-ball of slatyblack down, for he is densely covered at birth with down at least an inch long, and you could blow him away (Pouf!) if he were not so fat, and anchored in a hole. With the approach of the first spring he takes on first the feather-tufts, of a dull brownish hue, then the white facial mask, with corre-

Baby

Puffins sponding bill changes; but whether or not the yearling bird breeds, is an open question. The non-breeding birds remain at sea.

The Tufted Puffin enjoys the widest breeding-range of any bird in the North Pacific, except the Pigeon Guillemot; and, although not so thoroughly distributed as that species, it is undoubtedly far more abundant. On the American side, it breeds as far south as the Santa Barbara Islands, California, and as far north as Cape Lishurne, in northwestern Alaska; it is, however, of comparatively rare occurrence in Airctic waters. On the Asiatic side, its breeding range extends as far south as Japan; while its 
center of abundance is generally conceded to be the Aleutian Islands. Deposition of eggs occurs as early as May I in southern California, and as late as August I in northern latitudes; but fresh

Egg-laying eggs may also be found from June I to June 20 at any given point in its breeding range. Thus, on certain islets off the coast of Washington, I have found the Puffins punctual to a day, and deposition occurring with practical uniformity; whereas on the Farallones, 1911, there was a steady increase in numbers from the Ist to the 28th of May, with a few still to be heard from on June 3 . The winter range of this species comprises the open ocean, and the birds are occasionally driven shoreward along the Aleutian chain and the coasts of approximate latitudes.

From time immemorial, the natives of the North Pacific islands have placed large dependence upon the Puffins, both the Tufted and the Horned, to supply both food and clothing, and large numbers are caught annually by means of small nets mounted on poles,- - a sort of glorified butterfly hunt: Puffin meat is not distasteful, as sea-birds go, although white men do not care for it. More important to the native Usefulness Aleutian is the uniformly tough skin, which goes into the making of parkas, the famed feather-coats of the North. These garments, each requiring the use of from forty-five to fifty Puffin-skins, are made up feather-side in, and are nearly impervious. to cold.

We need no economic excuse to cloak our interest in these quaint oldmen-of-the-sea, the Tufted Puffins. Remote, unobtrusive though they be, they belong to us to study, to protect (as need arises), and to enjoy. A visit paid to one of their breeding-haunts is like a trip to fairyland, a real and tangible bit of romance. Such a privilege, properly exercised, is the inherent right of every American citizen, and should be safeguarded to our children for all time. The maintenance in full measure of these and other sea-fowl is so obvious an esthetic advantage to the race that no taint of commercialism ought to enter, at any point, into our consideration of them.

\section{Classification and Distribution}

The Tufted Puffin belongs to the Order Pygopodes, the Suborder Cepphi, the Family Alcida, and the Genus Lunda. Its scientific name is Lunda cirrhata. It inhabits the coasts and islands of the Arctic Ocean, Bering Sea and North Pacific, as far south as Japan and southern California.

This and other Educational Leaflets are for sale, at cents each, by the National Association of Audubon Societies, 1974 Broadway, New York City. Lists given on request. 


\section{THE CATBIRD}

BY WITMER STONE

\section{The National Association of Audubon Societies Educational Leaflet No. 70}

Most of our familiar American birds were named by the early settlers after well-known birds of the Old World to which they seemed to bear some resemblance. The Catbird, however, stood forth as a distinctive character of the New World, with no counterpart in the lands across the sea; and, as in many cases of bird-christening, they named him after the character of his voice, which recalled to them the mewing of a cat.

Even in America, the Catbird stands apart in a class by himself, so

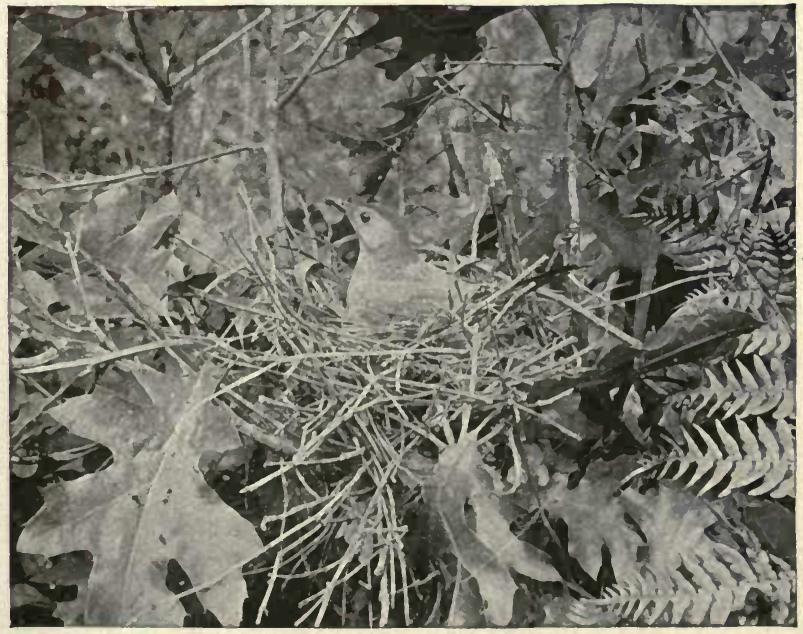

A GATBIRD AT HOME IN A MAPLE-BUSH

far as characteristics and color are concerned. We have learned, of course, that he is related to the Mockingbird and Thrashers, but perhaps not so very closely after all. His drab plumage, black cap and tail, and rusty under tail-coverts form a combination of colors not found, at any rate, among other "mockers," nor, indeed, in any other North American bird, while the deep blue eggs of the Cathird differ entirely from those of the Mockers and Thrashers, and recall those of the Thrushes, to which family, indeed, it would seem that the Catbird has some kinship. 
Through the Thrashers, on the other hand, he traces relationship to the Wrens, having the same short, rounded wing and long tail, and the tarsus composed of distinct plates and not welded together into a boot, as in the Thrushes.

Not only is the Catbird's plumage distinctive, but it is not subject to variation. Wherever found, Catbirds-male, female, and young, winter or summer-are alike.

Dr. Coues, I remember, in his classic account of the Catbird, refers to him as distinctly commonplace, and there seems to be something about the bird that deserves this epithet. $\mathrm{He}$ is so familiar to everyone, so associated with everyday scenes and occupations, that he seems almost

Inquisitive and

Confidential

a part of them, and occasions none of the enthusiasm that the brilliant plumage of the Scarlet Tanager or the clear notes of the Wood Thrush arouses. . And yet, when we stop to consider him, there is something very dear to us in the homely presence and the sometimes harsh voice of the Catbird.

The confidence that he seems to show toward mankind by living about the house, in dooryard, garden, or orchard-thicket, his apparent interest in everything that is going on, even if it border on inquisitiveness, and his song, low-pitched and erratic though it be, all endear him to us.

Every old garden, has somewhere about it a shady thicket of lilacs, mock-orange, or some similiar shrubbery in a niche by the back porch. perhaps, or behind the greenhouse, or over in the corner where the fences come together; and it is with such a spot that the Catbird is most closely associated in my mind. His song comes bubbling in through the open window, and let us but step outside and stroll down the garden-path, and the Catbird is at once close at hand, full of curiosity and nervous anxiety, uttering at frequent intervals that harsh, irritating, complaining cry.

When the house-cat selects some comfortable spot in the old garden for an afternoon nap, the Catbird is immediately at hand, and will mount guard by the hour with a continuous fire of harsh, monotonous, though utterly futile protests, so long as puss remains on the field. Perhaps,

A Home in the Thicket however, he may have good reason for his anxiety, for back in the heart of that shrubbery his nest is no doubt situated, lodged firmly among the branches, built of twigs, dead leaves and plant-stems, and neatly lined with fine rootlets, holding perhaps four deep blue eggs which his mate is patiently incubating. The number of eggs varies from three or five; and about the middle of May we find the clutch complete and incubation begun; and usually, I think, another brood is raised later on in June.

As the visitor passes out of his domain, the Catbird is back again among the lilac-bushes and, casting all anxiety to the winds, he ruffles out his plumage, droops his wings, and there gurgles forth that peculiar medley of liquid notes and harsh tones that strike one as almost ridiculous. The notes follow one another so unexpectedly that the whole pose 


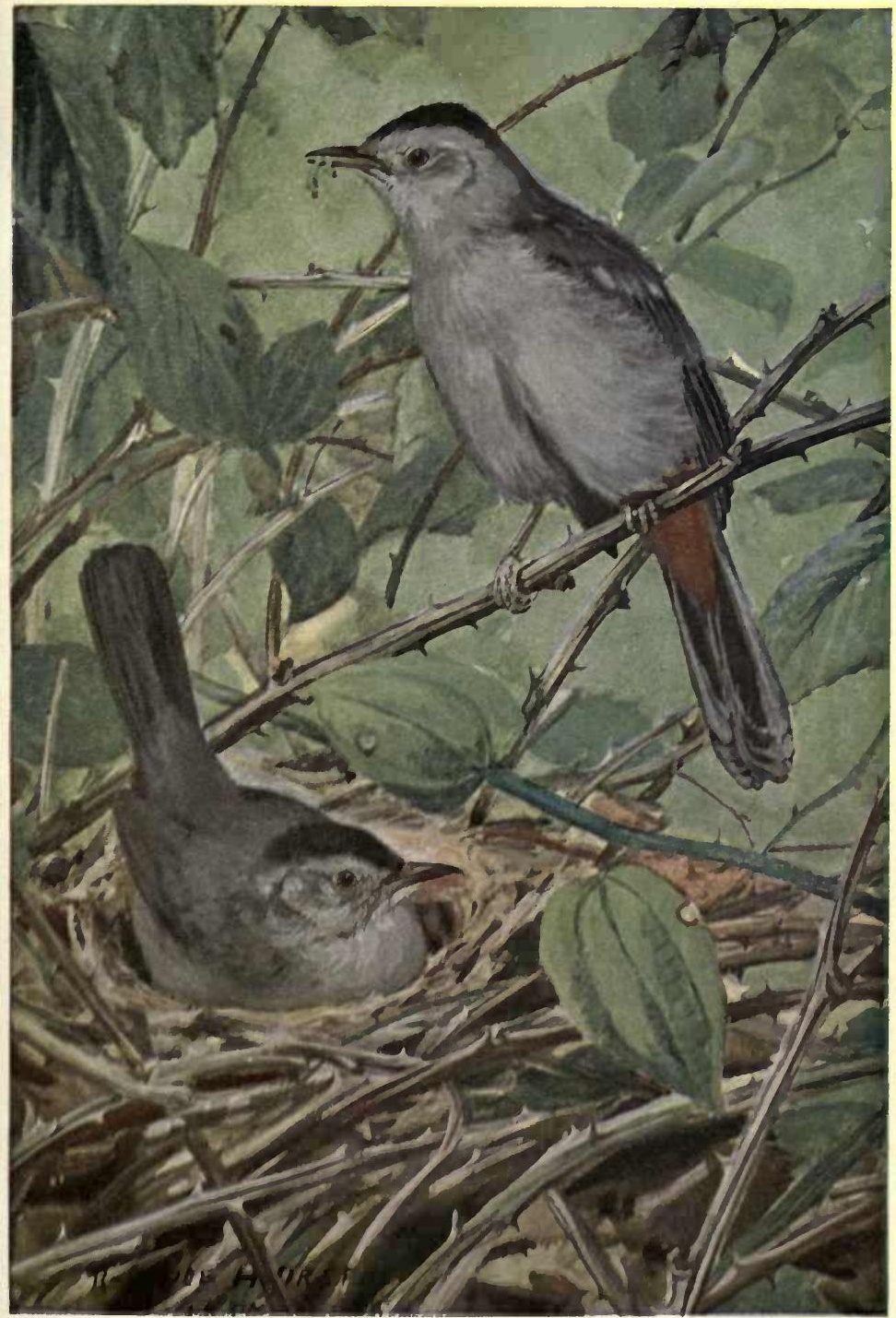

\section{CATBIRD}

Order-Passeres

Genus-Dumetella
Famliy-MiMida

SPOCIOS-CAROLINENSIS 



\section{The Catbird}

of the bird, his earnestness and entire satisfaction, seem somehow out of keeping with the result. But there is much that is pleasing-much melody -in the Catbird's song if we but give it consideration. It is not a loud song; not one that commands our attention, and not in a class with songs of Thrushes and Grosbeaks or the best Sparrow songs, but it is well suited to its surroundings, to the cool shade of deep shrubbery and the tangle of damp thickets, and it takes a prominent place in the wildbird chorus. The Catbird is by no means restricted to the garden shrubbery, but is equally at home down in the vegetable patch, among the grape-arbors, in the blackberry-briars bordering the orchard or down the lane that leads to the spring-house; and as you stroll along the old sunken road in the early evening one or more Catbirds are constantly in attendance,

A Bird of the Shrubbery darting along the rails of the decaying fence or perching for a moment on the top of one of the uprights, ever full of interest in your movements.

Out in the swamp, too, bordered with blackberry-bushes and wild plums, and overgrown with alder, spice-wood and fox-grape, we find Catbirds. As we penetrate the shady interior, bending below the green canopy and springing from tussock to tussock, we meet with the familiar protesting cry, the same apparent inquisitiveness to know what we are up to; and in among the dense tangle of grape-vine and greenbrier, we may find the nest as securely placed as in the garden shrubbery. Once, I remember, while exploring a swamp, I made a little squeaking noise with my lips placed against the back of the hand, such as is often employed to attract birds, and in a moment I had a small mob of excited Catbirds all around me, more than I supposed could possibly be within hearing. These swampy thickets probably harbor more Catbirds than any other place, notwithstanding the fact that in my mind the bird is more intimately associated with the dooryard of the farmhouse. Indeed, the swampy thickets and bushy borders of streams were probably the original home of the Catbirds before the advent of man, and it is in a certain swamp that I usually hear them first, and here, too, at the height of the breeding season, that we get their song at its best.

The Catbird retires southward in autumn, although occasionally as far north as New Jersey and southern Pennsylvania, or even New England, we come across an isolated Catbird that is wintering north of his usual range in

\section{Migration} some sheltering woodland tangle of greenbrier, or among the dense growth of bayberry-bushes on the coast. Here he manages to subsist on such berries as the autumnal migrants have passed by, or upon stray insects that are coaxed forth on mild days in winter by the warmth of the mid-day sun.

At Philadelphia, the first Catbirds arrive in the spring between April 15 and 24 , and they are generally distributed by the 29th. In the autumn, the last one has usually departed by the middle of October.

There is $x$ certain amount of feeling against the Catbird in some parts of the country on account of the fruit and berries that it consumes. 
As a matter of fact, however, fruit does not constitute a very large proportion of the Catbird's yearly food. The reports of the Department of Agriculture show that 44 per cent. of its food consists of insects, and three-fourths of this are made up of ants, beetles, caterpillars, and grasshoppers. Of the 56 per cent. of vegetable food, only one-third consists of strawberries, raspberries and blackberries, and many of these are the wild varieties. The other two-thirds are made up of berries of the dogwood, wild cherry, sour gum, elder, greenbrier, spicewood, black alder, sumac, and poison ivy-plants of the shady swamps and fence-rows where the Catbird so frequently makes his home.

We see, therefore, that the Catbird is of enormous value to the farmer

The Gardener's Friend as an insect-destroyer, while the charges against him as a fruit-thief dwindle in the light of scientific investigation, and can be largely dismissed by a little care in providing some of his favorite wild food. To quote Doctor Judd:

"By killing the birds, their services" as insect-destroyers would be lost forever, so the problem for t1s is to keep both tha bird and the fruit. We need have no hesitancy in placing the Catbird fairly in the class of beneficial birds. When we see him searching about the ground in his favorite thicket, we know that he is seeking out the many harmful insects that lurk there, and we need not begrudge him an occasional berry from the garden; since, if he should become a nuisance, we.know how to.draw him away from mischief. Considering the amount of food that a farmer provides for his crops in the form of fertilizer and manure, it seems strange if a little food cannot be nrovided for the birds, without whose constant guardianship crops of all kinds would be utterly wiped out by the insect-hordes."

\section{Classification and Distribution}

The Catbird belongs to the Order Passeres, and the Family Mimida. Its scientific name is Dumetella carolinensis. It is found in summer from the southern Provinces of Canada southward to northeastern Oregon, northern Utah, eastern Texas and northern Florida; and it winters from the Southern States solithward to Cuba and Panama. 


\section{THE TUFTED TITMOUSE}

BY FLORENCE MERRIAM BAILEY

\section{The National, Association of Audubon Societies}

\section{Educational Leaflet No. 71}

Emerson's poem, "The Titmouse," deals with the hardy Black-capped Chickadee in the snow-clad northern woods, but the gray Tufted Titmouse, which frequents the vine-draped woods of the Middle and Southeri States, is much the same friendly, cheerful little bird. In winter, when few birds are to be heard, the loud cheery whistle of the "Tom-tit," as it is sometimes called, makes the leafless woods seem alive again.

In spring, when the arbutus and the jessamine bloom in the South, the voices of the trio to which he belongs-Cardinal, Carolina Wren, and Titmouse-kcep the woods ringing with their songs. When heard for the first time in their daybreak or late-afternoon chorus, it may well puzzle one to tell which songster is which. But, by remembering that the characteristic

Mingled

Voices note of the gray Tom-tit is the two-syllabled pe-to, pe-to, or pe-ter, pe-ter, in distinction from the three-syllabled whee-u-dle, whee-u-dle, or teaket-tle, tea-ket-tle, of the brown Carolina Wren; and that they are both quite different from the smooth, long-clrawn cue, cue, cue, and the spirited whistles of the handsome red Cardinal, the principal songs of the three birds can soon be recognized.

But the Tom-tit is by no means bound down to one stereotyped song, for, though seeming so practical and business-like as he hunts over the branches, he hides a great variety of feelings under his pretty Quaker dress. These are expressed, as they are with many birds, either by small notes or by eloquent tones and variations in the characteristic song.

These enotional outbursts are really much more important in the life of birds than is the stereotyped song, for they take the place of talk in the family of the musician. They are best heard at the nest, where perhaps you may listen to a variety of small talk, such as the infantile, lisping notes of the hungry brooding bird coaxing her mate to feed her; the

\section{Emotional} Expressions tender note of her mate calling her to come to the door for the food he has brought; pretty conjugal notes of greeting and farewcll; the chattering scold and cries of anger, anxiety, or terror heard when enemics threaten; sharp notes of warning to the young, and wails of grief when harm has come to the nestlings. Such notes, given amphasis by vivacious, eloquent movements and gestures, interpret the thoughts and feelings of these intense little feathered folks almost as clearly as elaborate conversations do the emotions of iess demonstrative human beings. 
The various songs of the Tufted Titmouse have been carefully described by Nuttall, the old ornithologist, who says that "the Peto" and the Carolina Wren were his "constant and amusing companions" during a winter spent in the solitudes of the Southern States.

After writing that "the notes of the Peto generally partake of the high, echoing, clear tone of the Baltimore Bird," Nuttall describes what he calls peevish notes, "uttered in anger at being approached," answered,

Anger and perhaps, "by some neighboring rival, against whom Ridicule they appeared levelled in taunt and ridicule, being accompanied by extravagant gestures." These notes were given in a low, hoarse, "harsh voice, and in a peevish tone exactly like that of the Jay and the Chickadee . . day-day-day-day, and dayday-day-day-dait," sometimes becoming low and querulous. 'Tshica-dee-de and kai-tee-did did-dit-did were other variations.

"Later in the season, in February," Nuttall goes on to say, "when, in the lower part of Alabama, the mild influence of spring began already to be felt, our favorite, as he gaily pursued the busy tribe of insects, now his principal food, called, as he vaulted restlessly from branch to branch, in an echoing, rapid voice, at short intervals, peto-peto-peto-peto. This tender call of recognition was at length answered, and continued at intervals for a minute or two; they then changed their quick call into a slower peto pétó pétó; and now the natural note passed into the plaintive key, sounding like que-ah que-ah; then, in the same breath, a jarring note, like that of the Catbird, and, in part, like the sound made by putting the lower lip to the upper teeth, and calling 'tsh 'vah, 'tsh 'vah. After this a call of kerry-kerry-kerry-kerry struck up with an echoing sound At length, more delicately than the first, in an undertone, you hear anew, and in a tender accent, peto peto peto peto. In the caprice and humor of our performer, tied by no rules but those of momentary feeling, the expression will perhaps change into a slow and full peet-peet$a$-peet-a-peet, then a low and very rapid ker-ker-ker-

Nuttall's

Interpretation ker-ker-kerry, sometimes so quick as almost to resemble the rattle of a watchman. At another time his morning song commences like the gentle whispers of an aerial spirit, and then becoming high and clear like the voice of the Nightingale, he cries keva keva keva keva; but soon falling into the querulous, the dayday-day-day-day-dait of the Chickadee terminates his performance. Imitative, as well as inventive," Nuttall continues, "I have heard the Peto also sing something like the lively chatter of the Swallow, leta-leta-letaletalit, and then vary into peto-peto-peto-peto extremely quick."

In conclusion Nuttall says that while the song of the Peto is confined to these "simple, playful, or pathetic calls, yet the compass of voice and the tone in which they are uttered, their capricious variety, and their general effect, at the season of the year when they are heard, are quite as pleasing to the contemplative observer as the more exquisite notes of the summer songsters of the verdant forest." 


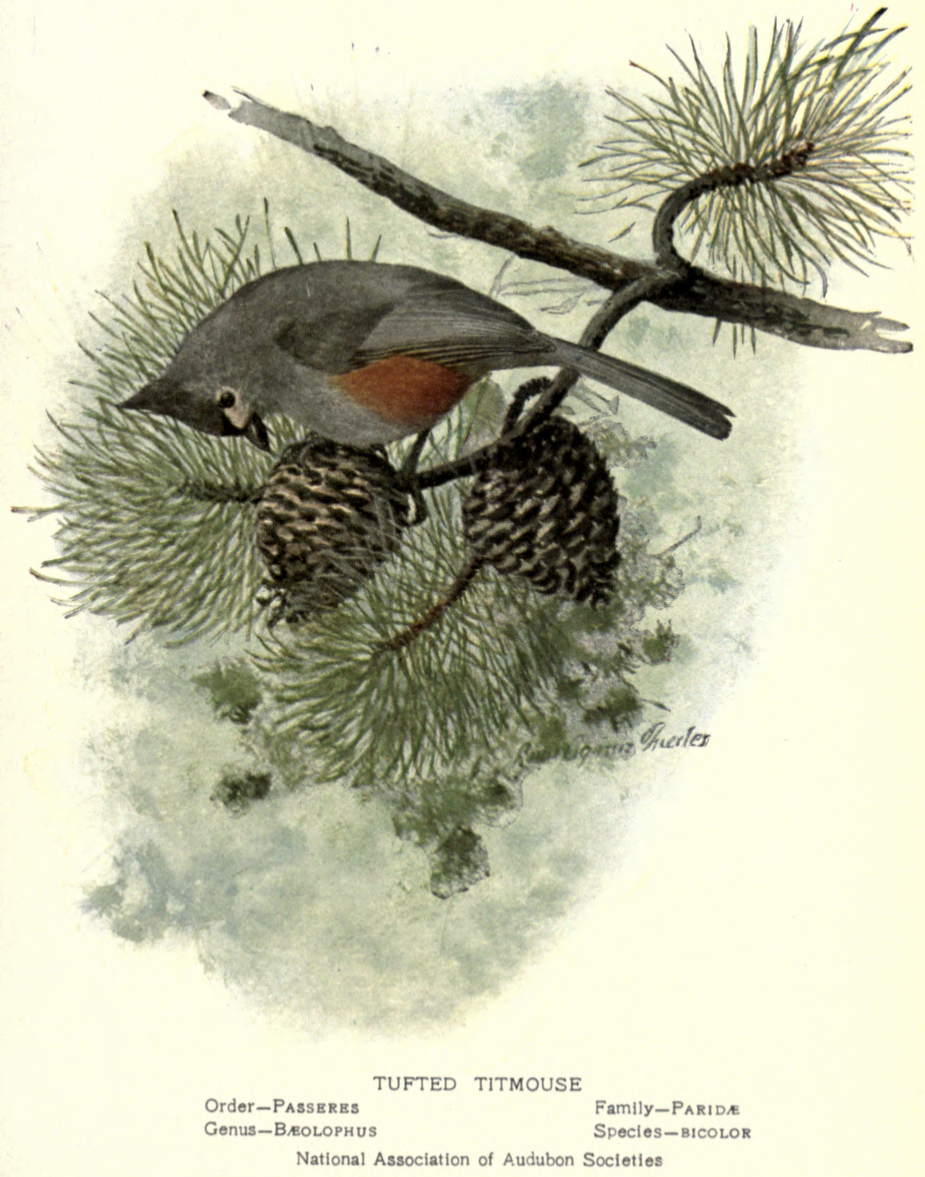



The varied notes and tones of the Titmouse easily interpret its changing moods, but an additional clue to its state of mind is given by its use of its crest. For, though it generally deserves the name sometimes given-"Top-knot Bird"-when preoccupied in hunting for its dinner, or forcing itself

\section{An Expressive}

Crest to brave danger, it may change its expression entirely by flattening its crest until, except for a point at the back of its head, it is almost as round-headed as a Chickadee.

Like Emerson's Chickadee, the Tom-tit

"Shows feats of his gymnastic play,

Head downward, clinging to the spray."

but it is dinner rather than gymnastics that he is thinking of. Leaves and cracks and crannies of bark he is examining with microscopic care for insects or their eggs or larvæ.

When not hunting insect-eggs like a Chickadee, the Tom-tit may be cracking nuts like a Blue Jay, hammering away at one held firmly under his foot. Beechnuts, hazelnuts, chinquapins, or even acorns, he accepts cheerfully. Wild berries, such as those of dogwood and Virginia creeper, are also taken in their turn; and, in their proper season, grasshoppers, beetles, cutworms

\section{Varied \\ Fare} and caterpillars form a large part of his diet. Boll-weevils and scaleinsects, two of the worst insect pests of the country, are sometimes eaten by him; while his nearest relatives in California and the Southwest take an active part in destroying these dangerous enemies of man. The Titmice do good by eating the insects, and also by carrying them to their voracious young in the nest.

The nest of the Tom-tit, like that of the Chickadee, is almost always in a ready-made hollow, very often in a deserted Woodpecker's nest, especially in that of the Red-bellied Woodpecker. On rare occasions the Tom-tit is said to excavate its own nest.

To line the hollows the birds carry in a variety of materials. For foundation they sometimes use grasses, strips of bark and Spanish moss, filling in with a lining of soft materials such as feathers and hair. Where do they get these

Furnishing the Nest soft furnishings? That is one of the many interesting things to find out. A hair-gatherer was once seen, as the observer supposed, trying to drive off a red squirrel. But field-glasses told a different story. The squirrel lay resting on a branch and the Titmouse "would approach cautiously from behind and catch at its tail." The industrious bird kept doing this until it "had collected quite a mouthful of the hairs, with which it flew off to a hole nearby, where it was deposited!"

The observer does not tell us whether the squirrel was asleep or whether it remonstrated with its small neighbor; but the incident shows that many surprising things are to be seen and heard in the woods. Another case is recorded of one of these Titmice getting hairs from a living dog; and a second of a young lady who was astonished to find one of 
these enterprising birds trying to pull hairs from her carefully arranged locks!

While the Tom-tit usually nests in a hole in a tree or stump, one eccentric bird has been found building in a bunch of Spanish moss. When a violent storm came, her eggs were blown to the ground But, as the observer says, "undismayed, she began to work again in the

\section{Nesting in} Moss same bunch of moss." Her mate did not approve of this, and "would fly into a hollow near at hand and whistle for her." It did no good, however. She went and looked into the hole he had picked out, but then went back to the moss, working rapidly and carrying "huge mouthfuls at every trip." It was all in vain. When her eggs were laid another storm came and both eggs and nest were found on the ground. The nest, besides dry leaves, hair, sedge, and feathers, contained snake-skins!

All this goes to prove that birds are not all alike, any more than people are; that it is never safe to say aizways and never about birds' habits; and that, in watching birds it pays to keep one's eyes and ears wide open.

The eggs of this Titmouse vary from five to eight, and are white, marked with brown.

The dependence of the Tom-tits on holes in trees for nesting-sites is illustrated by a case in Missouri, where the "hard and gnarled black-

\section{Using a}

Nest-box

jacks failed to afford the necessary hollows, and, where, consequently, Titmice and birds of similar habits were missing. When nesting-boxes were put up for Bluebirds and Wrens a pair of Tom-tits took possession of one of them and raised their brood in it.

Not only do the Titmice need holes to nest in in summer, but to roost in in winter, for unlike most birds the hardy little fellows do not go south in the autumn, but spend the winter where they have passed the summer. Like Emerson's Titmouse, they might read us an excellent moral:

\section{Live out-of-doors}

In the great woods, on prairie floors.

I dine in the sun; when he sinks in the sea,

I too have a hole in a hollow tree.

For well the soul, if stout within,

Can arm impregnably the skin.

\section{Classification and Distribution}

The Tufted Titmouse belongs to the Order Passeres and to the Family Parida. Its scientific name is Balophus bicolor. It is found from Nebraska. Iowa, Ohio, and New Jersey, southward to central Texas, the Gulf coast and Florida; and occasionally as far north as the southern parts of Wisconsin, Michigan, New York and Connecticut. 


\title{
THE WOOD THRUSH
}

\author{
BY T. GILBERT PEARSON
}

\section{The National Association of Audubon Societies}

Educational Leaflet No. 72

Throughout the southern part of its range this bird is widely known as the Wood Robin. Altogether, this is not a bad name. The Wood Thrush is not far from the size of our well-known and much-beloved Redbreast, and its movements, when walking or hopping along the

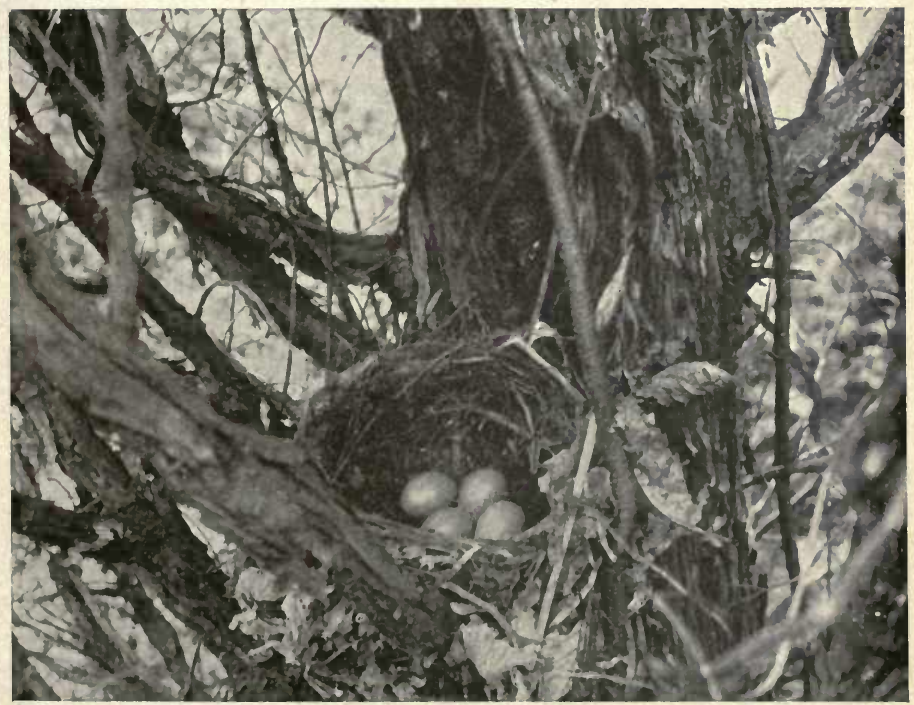

NEST AND EGGS OF WOOD THRUSH IN CEDAR TREE, DEMAREST. N. J. Photographed by B. S. Bowdish

ground, are strikingly similar to those of this well-known species. A ncar approach reveals the fact that the general marking, particularly the heavily spotted breast, is quite distinct. At close range, therefore, there is little possibility of even the most amateur student confusing the two birds in the adult plumage. The wonderfully melodious song of this Thrush is highly characteristic. As Dr. Chapman has said, "It is a message of hope and good cheer in the morning, a benediction at the close of day." 
"In Useful Birds and Their Protection," Mr. E. H. Forbush has written: "The song of the Wood Thrush is one of the finest specimens of bird music that America can produce. Among all the bird songs

Heavenly

Music

that I have heard it is second only in quality to that of the Hermit Thrush. It is not projected upon the still air with the effort that characterizes the bold and vigorous lay of the Robin, or the loud and intermittent carol of the Thrasher. Its tones are solemn and serene. They seem to harmonize with the sounds of the forest, the whispering breeze, the purling water, or the falling of rain-drops in the woods. As with most other birds, there is a great difference in the excellence of individual performers, and, while some males of the species can produce such notes as few birds can rival, this cannot be said of all. At evening the bird usually mounts to the higher branches of the taller trees, often upon the edge of the forest, where nothing intervenes to confine or subdue his 'heavenly music.' There, sitting quite erect, he emits his wonderful notes in the most leisurely fashion, and apparently with little effort. A-olle, he sings and rests; then, unhurried, pours forth a series of intermittent strains, which seem to express in music the sentiment of nature; powerful, rich metallic, with the vanishing vibratory tones of the bell, they seem like a vocal expression of the mystery of the universe, clothed in a melody so pure and etheral that the soul, still bound to its earthly tenement, can neither imitate nor describe it. The song rises and falls, swells and dies away, until dark night has fallen. The alarm note of the bird is sharp pit, pit, several times repeated; this alarm often rises to a long roll. A soft cluck, also repeated, is sometimes heard. A mellow, rather liquid, chirp is another common note."

The Wood Thrush is not among the early feathered arrivals in spring. In fact, we do not see it until the new leaves are well started, and warm weather has advanced sufficiently to render improbable the recurrence of one of those backward blasts of winter which so often

In Spring occur in early spring. It is during the last ten days of April that we usually find the first Wood Thrush. in the latitude of New York. Within a few days after his song is heard ringing through the woodlands, practically all the Wood Thrush delegation arrives. Love-making shortly begins, and full complements of eggs may be looked for within three weeks.

The building of a nest to suit the taste of a pair of Wood Thrushes involves no small amount of labor. Although the birds feed on the ground, and spend much of their time running or hopping about in the grass or among the fallen leaves, they do not regard this as a good place for their eggs and young.

$\mathrm{Up}_{\mathrm{p}}$ in a small tree, from six to ten feet above the earth, they choose their nesting-site. The fork of an upright limb, or where the main stem of a sapling divides, is looked upon as a choice situation. Here large dead leaves, and sometimes pieces of paper, are brought, and these, held 


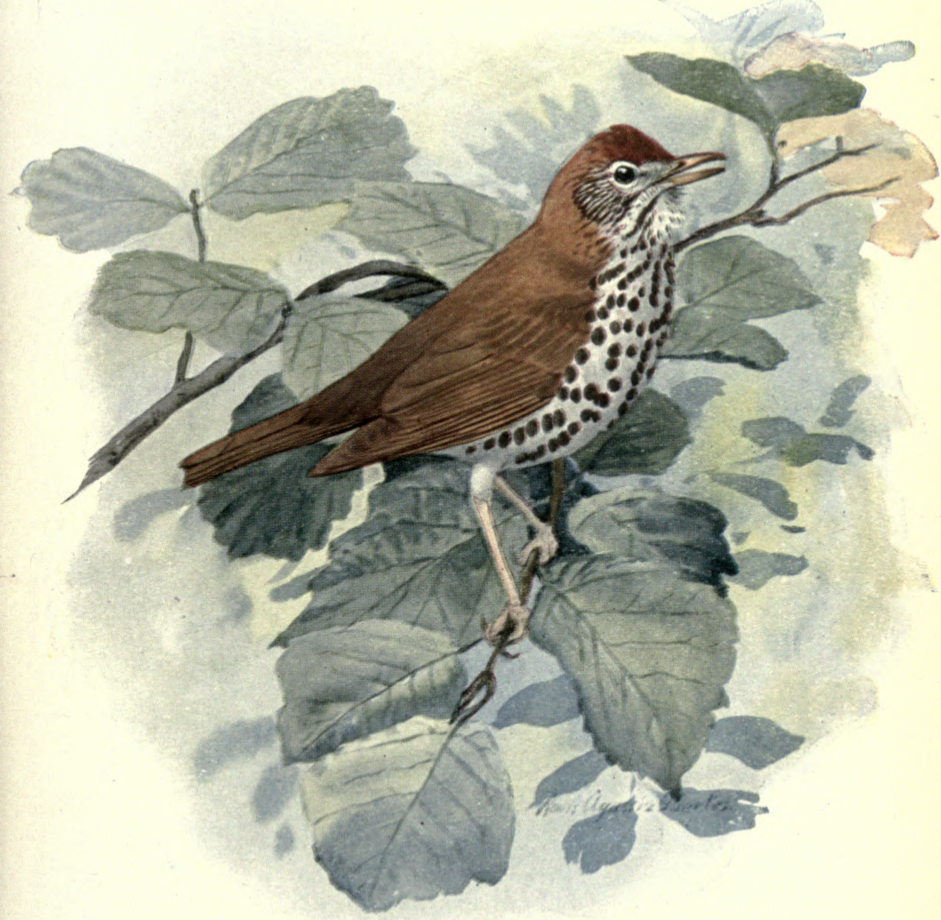

WOOD THRUSH

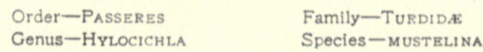

National Association of Audubon Socleties 



\section{The Wood Thrush}

together with sticks and twigs, form the bottom and sides of the structure. Mud is brought to make the inner cup secure and strong. This feature of the nest follows closely the architectural plan employed by the Robin. The similarity ends here, however, for the Wood Thrush's nest is usually lined with fine rootlets, while the Robin seems to prefer dried grass for this purpose. In this secure structure the baby birds usually find a safe cradle until the time comes for them to launch forth into the world of dangers about them.

The eggs are usually deposited one each day, until the full complement has been reached. Four is the number most usually laid,

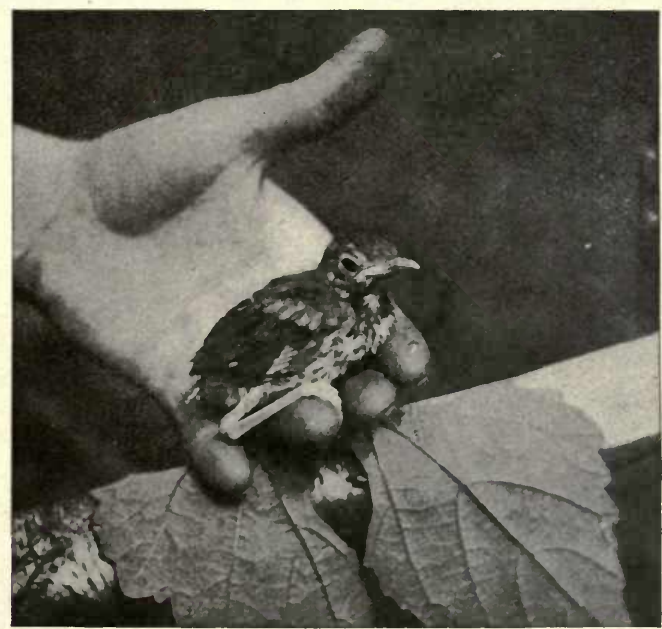

YOUNG WOOD THRUSH JUST AFTER LEAVING NEST

Photographed by B. S. Bowdish

although the bird may sometimes be found engaged in the business of incubation with only three, and, again, five may be seen. The color is a delightful bluish-green, but compared with other green eggs this tint is lighter-

Eggs tiot so deep as that of the Catbird's eggs. In fact these eggs resemble very closely those of the Robin, and if they were only slightly darker, it would be almost impossible to distinguish the two.

In reference to its food, the Wood Thrush is classified as an insecteating bird, and its value as such has become so generally recognized that it is now protected by local laws in all parts of the United States where it is found. As an additional safeguard, a measure, known as the McLean, or Migratory Bird Law, which was enacted by Congress 
in the year 1913, absolutely prohibits the killing of these birds at all seasons in all parts of the country.

Thus the bird now dwells beneath the combined protection of the Government and the several States. As most of this bird's life is passed on the ground or among the shrubbery, we would Food naturally expect it to eat those small forms of life found in such situations. Practically any insect which it comes upon in its apparently aimless travels about the groves and thickets is doomed to speedy destruction, unless escape is instantly effected.

Beetles that inhabit the ground or the bark of trees are eaten, as well as grasshoppers, snails, spiders, and the larvæ of many moths and other succulent insects. Now and then the bird steals into the garden to take a gooseberry or blackberry, but if the earth has been recently spaded it shows a decided preference for any cutworm, or other underground worm of similar character, that may have been exposed to the light of day. Wood Thrushes eat wild fruit and berries to some extent, but their characteristic shyness evidently prevents them from acquiring that intimacy with mankind which would tend to make them feel as much at home in the cherry tree as does our dear, but at times annoying, Robin.

There are few birds which make so strong an appeal to the nature lover as does the Wood Thrush. Many are the things to be said in its favor, and rare, indeed, is it to find anyone who, knowing this shy sylvan beauty, has aught to say against it. It is one of the few well-known birds which is universally popular, and it deserves all the protection which mankind can give it.

All wild creatures, of course, have their enemies. Snakes, weasels, hawks, and owls are among what we may call the natural enemies of small birds. Against these destroyers our feathered friends have for long centuries been able to hold their own in numbers. Enemies Mankind, however, has brought many changes in the wild-life conditions of the country, and, while we have destroyed many of the creatures which formerly thinned the Wood Thrush ranks, we have introduced others whose destructive effects are vastly more potent. Here is the tragic trio which we have let loose upon American wild-bird life: the sling-shot boy, the all-eating Italian, and the ravenous house-cat.

\section{Classification and Distribution}

The Wood Thrush belongs to the Order Passeres. Suborder Oscines, Family Turdida, and Subfamily Turdinc. Its scientific name is Hylocichla mustelina. It 1.reeds from southern South Dakota and southern New Hampshire, sonth to eastern Texas and northern Florida, and winters from southern Mexico to Nicaragua and Costa Rica, occurring casually in winter as far north as New Jersey.

This and other Educational Leaflets are for sale, at 5 cents each, by the National Association of Audubon Societies, 1974 Broadway. New York City. Lists given on request. 


\section{THE WHIP-POOR - WILL}

By T. GILBERT PEARSON

\section{The National Association of Audubon Societies Educational Leaflet No. 73}

While walking along a country road one evening after the sun had set and darkness had all but fallen, I suddenly discovered some object on the ground a few yards ahead. At almost the same moment it rose, and, on slow-moving wings, flew over the fence and disappeared in the gloom of the woods. The flight was so silent, and the wings were so broad, it was difficult to believe that it was not a great moth that had just departed from view. I knew, however, that I had disturbed a Whip-poor-will in the midst of its twilight dust-bath. Evidently it had been trying for several minutes to find just the right spot, for there in the soft earth were three slight but distinct hollows, such as only a dusting bird would make.

Soon afterward I heard it calling, or perhaps it was its mate, whippoor-will, whip-poor-will; the shouts came ringing through the darkness, six, eight, or perhaps twenty times repeated. Then, after a pause, the plaintive but stirring notes would again come up from The Song

the old apple orchard, and fill all the space round about the farm-house. The still summer night seemed to belong to this strange bird of the shadows, for its rhythmical cry took possession of the silences, and filled the listener with contented exhilaration. All attempts to approach it that night were futile, for its big, bright eyes evidently penetrated the shadows with ease, and, long before we could even make out its form, it would fly to another perch several rods away. Only when it announced its presence by calling did we know its position. Two or three times, however, we came near enough to hear the low note, something like chuck, which immediately precedes the first loud whip of its song.

Ernest Ingersoll, in his book "Wit of the Wild," says a Whip-poorwill, while singing, "will often make a beginning and then seem to stop and try it over again, like a person practicing a new tune; but these interruptions really mean so many leaps into the air,

Stops Singing to Fat with perhaps frantic dodges and a somersault or two, for the snatching and devouring of some lusty insect that objects to the process." We listened for this, but all the calls we heard were complete throughout each performance. It was fully two hours after the sun had set before the last note of this mysterious nightflyer was heard. Just before dawn it called again several times, and the farmer's wife said she feared it was sitting on the stone door-step. She was somewhat disturbed about this, and intimated that if it were there the 
action would bring sorrow to the household. It seems odd that people should be superstitious about anything as harmless as a bird, but in rural communities one often finds people who believe much ill-luck may happen to them if a Whip-poor-will sings too close to the house. If they were better acquainted with this gentle, feathered creature, they would surely know that nothing evil could come from it.

Many more people have heard this bird call than have ever seen it, for, like the owl, its day begins only when the sun goes down, and before the sun comes up again it has settled to sleep on the dead leaves that cover the ground in the thicker parts of the woods. It appears never to give its call during the daytime. While hunting for wild flowers you will sometimes come upon its hiding-place. It must sleep with one ear open, for the bird seems always to hear you before you see it, and on silent wings it will rise and fly quickly out of sight among the bushes.

If such an experience should happen to one in the months of May or June, it is quite worth while to search the leaves very carefully, for you may have stumbled upon the nest, which, in reality, is no nest at all, but is simply a place on the leaves that the mother-

Nest

bird has chosen to be the temporary home of her little ones. The faintly spotted, cream-colored eggs so closely resemble the faded, washed-out, last season's leaves on which they are lying, that it takes a sharp eye, indeed, to find them. So one should proceed slowly, lest an unfortunate step might crush the two little oblong beauties. Usually one is not quite certain of the exact spot from which the bird flew. On such occasions I sometimes place my hat or handkerchief on the ground near the place, and, like a dog hunting for a lost trail, begin to walk around the spot, increasing the circle constantly as I go. By this means, sooner or later, one will be pretty sure to find the eggs if they are there.

If, when the bird flies, it soon comes to the earth again, and appears to be suffering from sudden injury, you may be sure that it has a secret that it is trying to keep from you, and, by feigning a broken wing, it

hopes you will follow in an attempt to capture it.

Feigning Injury If you approach the bird, it will fly before you a

few yards at a time until, having led you away a safe distance from the nest, it will suddenly recover, and, then, rising strong on the wing, you will see it no more. Doubtless the eggs are often saved from destruction in this way, for a hunting dog, fox, or 'coon, will seek to catch the bird, and entirely overlook the presence of eggs or young.

If the eggs have hatched you will need to look even closer if you are to be rewarded. The two little Whip-poor-wills, with their soft, downy coats, will lie motionless on the leaves, without even so much as an eyelid moving to betray their presence. Their coloring, too, blends so wonderfully with their surroundings that I sometimes wonder if any enemy is ever able to find them.

In many of the Southern States lives the Chuck-will's-widow, which also bears the name given to its call. It is larger than the Whip-poor- 


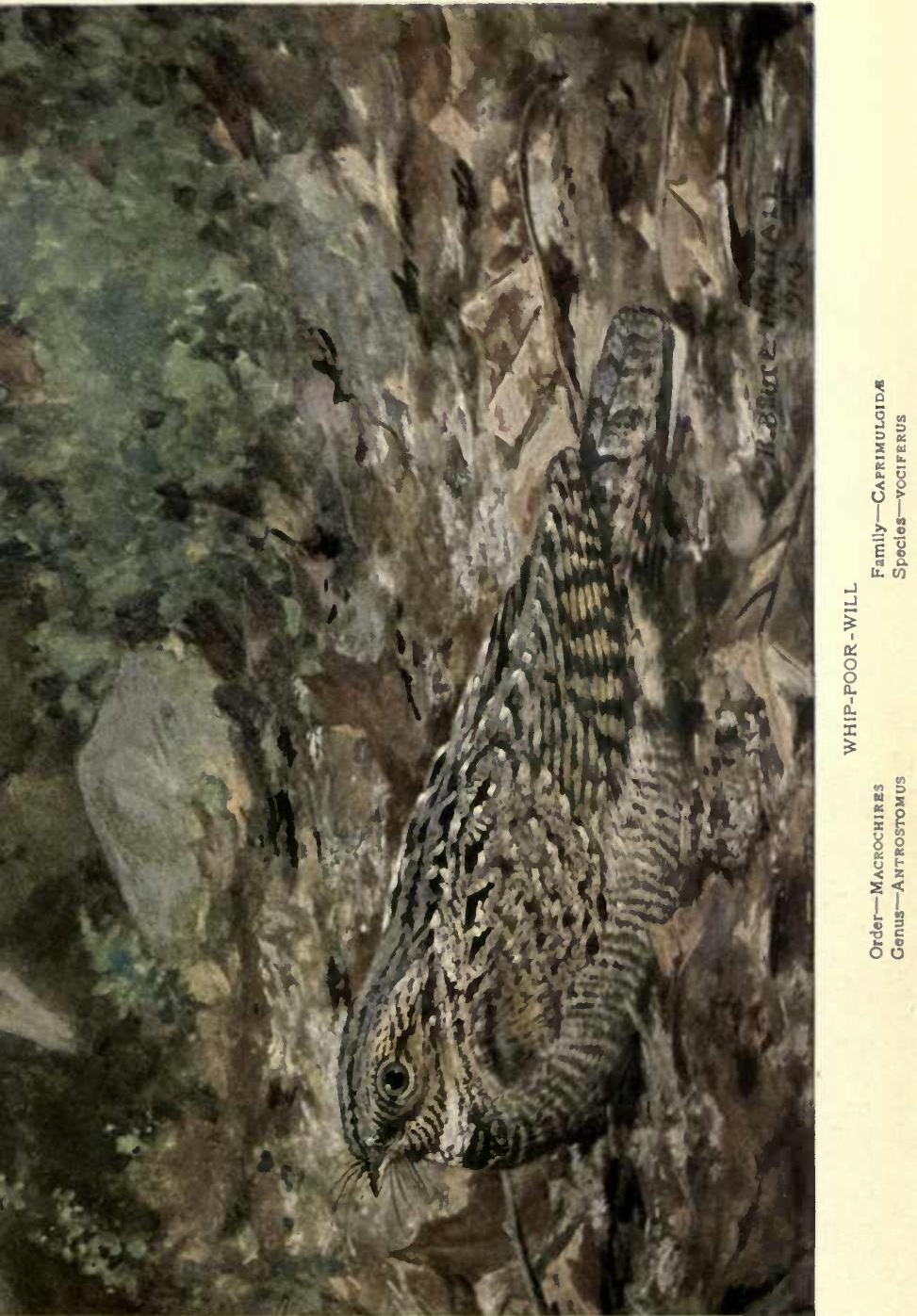


20

,

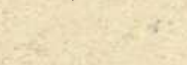

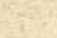


will, but, like it, is nocturnal in its habits. So closely do the two birds resemble each other, both in physical structure and in habits, that naturalists tell us they are near relatives, and, in fact, they classify them as belonging to the same family. Many of the people who live in the forests where these birds are found do not know much about the scientific study of birds, and usually believe that these two night-prowlers are one and the same birds. They will tell you that the Chuck-will's-widow is the male Whip-poor-will.

Down in the lake country of central Florida, as a boy, I used to listen to the Chuck-will's-widow calling on summer nights. When the winter months came, however, the cries that came up from the deep woods of an evening were different, for at that season these bircls were all gone, and their places taken by Whip-poor-wills which had arrived from the more northern States to pass the winter where the snows never fall, and frosts seldom come.

Another closely related bird is often confused in the public mind with the Whip-poor-will. This is the Nighthawk, or "Bull-bat." Very many persons think there is no difference in these bircls, but there is a marked difference, both in appearance and habits. The Nighthawk's wings are much longer, and, when folded, reach well beyond the end of the tail, while the Whip-

Its Cousin the Nighthawk poor-will's wings do not extend even as far as the end of the tail. The Nighthawk flies about in the early evening, long before sunset, and may sometimes be seen, even at noontime, hawking about for insects. It often feeds hundreds of feet in the air, and may remain on the wing for an hour or more at a time. On the other hand, its cousin of the shadows comes out of its seclusion so late in the evening only, that it is difficult to see it, and it captures its food by short flights near the ground.

The Whip-poor-will, and the other two birds I have mentioned, belong to the family of birds called Goatsuckers. They have very weak feet and legs, and so move very slowly and feebly when on the ground. They sit lengthwise on a limb, fence-rail, or other object on which they chance to perch, and very rarely use the crosswise position so commonly adapted by the perching birds. The mouth in this group is one of the wonders of the bird-world because of its enormous size. All around the upper lip is arranged a series of long, stiff, curving hairs, which form a sort of broad scoop-net in which the bird entangles and seizes its insectprey, for it always feeds while on the wing, and the agile gnats and moths might often be able to dodge or slip out of the very small beak possessed by these birds were it not for the widle fringe of bristles.

Few birds are more valuable to the farmer than is the Whip-poor-will. It never does him any harm in any way, for it does not eat his cherries and strawberries, nor does it pull up his newly planted corn, nor eat his millet seed. It does not fill up the drainage-pipes of his house witl sticks and leaves as do the Wrens; it does not eat his chicken-feed as do the pestiferous European Sparrows, nor catch lis young poultry. What it does for him is to eat the ever-swarming insects that lay the eggs that 
latch into caterpillars and destroy the leaves of shade and fruit-trees. May-beetles and leaf-eating beetles are destroyed by it also. In truth, fortunate, indeed, is the grower of grain, or the raiser of fruit who, during the spring and summer nights, has one or more pairs of these birds about his place, for all during the hours when the farmer sleeps the Whip-poor-will is busy ridding his place of these harmful insects.

Mr. Ingersoll says: "They never regularly sweep through the upper air as does the Nighthawk, but seẹ their food near the ground by leaping after it in short, erratic flights. They have a way of balancing themselves near a tree-trunk or barn-wall, picking ants and other small provender off the bark; and even hunt for worms and beetles on the ground, turning over the leaves to root them out. It is not urtil their first hunger

has been assuaged that one hears that long, steady

Insect Catching chanting for which the bird is distinguished, and which, as a sustained effort, is perhaps unequalled elsewhere. . . . It is an ordinary feat for him to 'whip-poor-will' with two or three hundred strokes in unbroken succession."

In the early autumn, the Whip-poor-wills simply disappear without warning. As they reappear far to the south, we know, of course, that they have migrated, but when did they go and how? Did they journey over the hundreds of miles of intervening space by short flights, or did they mount high in air, as do many small birds, and fly swiftly for long hours at a time? Did they go singly or in flocks? These and other questions about this mysterious bird of the night remain to be answered fully. Perhaps some young reader of this paper will grow up to be a naturalist who will explain these things' more fully to the less observant students of birds.

No one should ever kill one of these useful birds. Its great value to mankind has become generally recognized in recent years, and the laws of all States where the bird is found provide that anyone who kills a Whip-poor-will shall be fined or imprisoned.

\section{Classification and Distribution}

The Whip-poor-will belongs to the Order Macrochires and Family Capri mulgidae; and its scientific name is Antrostomus zociferus vociferus. It ranges through eastern North America, breeding from the St. Lawrence Valley and Nova Scotia south to northern Georsia and Louisiana, as far west as the border of the Plains; it winters from the South Atlantic and Gulf Coast to British Honduras. The only other subspecies is macromystox, of Mexico and the adjacent border of the United States.

This and other Educational Leaflets are for sale, at 5 cents each, by the National Association of Audubon Sacieties, 1974 Broadway, New York City. Lists given on request. 


\section{THE ROSEATE SPOONBILL}

By FRANK M. CHAPMAN

\section{The National Association of Audubon Societies}

\section{Educational Leaflet No. 74}

When Dr. Henry Bryant visited Pelican Island, in Indian River, Florida, in 1858 , he found not only Brown Pelicans but also Roseate Spoonbills nesting there. But even at that early date these beautiful and interesting birds were prey for the plume-hunters, some of whom, Dr. Bryant writes, were killing as many as sixty Spoonbills a day, and sending their wings to St. Augustine to be sold as fans.

From that time almost to the present day "I'ink Curlews," as the Floridan calls them, have been a mark for every man with a gun. Only a remnant was left when the National Association of Audubon Societies began to protest against the further wanton destruction of bird-life, and, by the establishment of reservations, and a system of guarding them by wardens, attempted to do for Florida Saving the Birds what that State had not enough foresight to do for itself. Unfortunately, Florida is not alone in this neglect.

By such precautions the Spoonbill and other birds have been saved to delight future generations of nature-lovers. Warden Kroegel, of Pelican Island, tells me that in June, 1913, he saw a flock of sixty on the Mosquito Inlet Reservation; and on the day I pen these lines word comes from President Blackman, of the Florida Auduben Society, that he had seen fifty Spoonbills on Bird Island, on the Gulf Coast. So let us hope that what I have to write here relates not to a species approaching extinction, but to one which, under proper guardianship, is increasing, and will continue to increase.

The Roseate Spoonbill belongs to one of those families of birds which, like the Ibises, Parrots, Trogons, and many others, are distributed throughout the warmer parts of the earth. Thus there are European, African, Asian, and Australian Spoonbills, all with the singularly shaped bill to which they owe their common name, but none pink like ours. This small

\section{Distribution} family contains only six members; and how they have become so widely scattered geographically is a question no one has answered satisfactorily. It is, however, known that at one time -in the earth's history what are now Arctic regions were very much warmer; and it is probable that at that period Spoonbills lived on the border of the Arctic Sea, which was then bordered by a vegetation resembling that now found in our Southern States. When, toward the close of the Tertiary Era, the climate gradually grew colder, until finally the ice-cap of the Glacial Period formed all over 
the northern part of the continents, Spoonbills, with other birds, were forced southward into the warmer parts of both the Old World and the American continent. In that way the Spoonbill family, which previously had dwelt together all around the borders of the Polar Sea, became separated into groups, each of which, in its new home, developed specific differences.

Of the six species now known America received but one, the Roseate Spoonbill, whose peculiar scientific title (Ajaia ajaja) is based on the name given it by certain South American Indians.

Names When naturalists first knew this bird it was found throughout tropical America north to our Gulf States from Texas to Florida. In the United States it is now confined mainly to southern Florida.

Although I first went to Florida in 1887 , it was not until 1908 that I saw Spoonbills there. Doubtless always more common on the coast than in the interior, the few survivors were then to be found only in the most remote part of the great mangrove swamps south of the Everglades. On the evening of March 29, I908, after traveling all day through mud and mangroves, we reached the Cuthbert rookery, near the extreme southern part of the peninsula, and saw, to our intense satisfaction, that among the thousands of Herons nesting on it were about forty Spoonbills.

The beautiful peach-bloom-like pink of the Spoonbills is noticeable at a great distance. In manner of flight they resemble Ibises rather than Herons, the neck being held fully extended. The flock formation is also like that sometimes assumed by the Ibis, each bird flying behind, but a little to one side of the bird before it, making a diagonal file. Spoonbills, however, so far as I have observed, maintain a steady flapping of the wings, not interrupted by short sailings, as in the case of the Ibis.

The Spoonbill's peculiarly shaped beak is adapted to an equally peculiar method of procuring food. I have never been close to one of these birds when feeding in its native haunts, but Audubon tells us that they "wade up to the tibia [shank] and immerse their

Feeding bills in the water or soft mud, sometimes with the head and even whole neck beneath the surface. They move their partially opened mandibles laterally to and fro with a considerable degree of elegance, munching the fry, insects, or small fish which they secure before swallowing them."

Audubon says nothing of the voice of the Spoonbill. At the Cuthbert rookery I heard no notes I could identify as their's, but two years later, in Mexico, I heard them utter a low, croaking call at their nests. T. Gilbert Pearson, who once watched a flock of them feeding at close quarters, says that this grunting sound was continuous, as if the birds kept up a kind of conversation among themselves.

Fear in animals is so often born of pursuit by man that it is frequently difficult to say whether birds that have been much hunted are shy instinctively or intelligently. Wild Ducks, we know, are as wary as birds 



\section{The Roseate Spoonbill}

well can be where they are shot, but surprisingly tame where they are protected and fed. I have seen White Egrets roost nightly near a hacienda in Cuba where they had learned they were safe, but those in the Cuthbert rookery were startled into sudden flight by the report of a gun fired at a distance of a mile and a half. If, therefore, Spoonbills could be made to realize that man was their friend rather than their enemy, they, too, might learn to trust him.

Although the Spoonbills in the Cuthbert rookery had nests containing eggs, they deserted them as soon as we entered the rookery. An umbrella-blind was placed in one of the larger mangrove bushes, but after hours of waiting no Spoonbills were seen. At sunset the birds of various species began to return to the rookery for the night. Flock after flock of White

\section{In Cuthbert Rookery} Ibises, with bright red feet and faces, came to roost in favorite trees. Louisiana herons greeted, with much talking, birds that had evidently been absent during the day. Turkey Vultures silently sailed in to perch in rows on the branches of a dead tree; and suddenly six Spoonbills, with resonant z'oof-woof-woof of beating wings, alighted in my foregroundone of them within fifteen feet of me. As it grew darker the birds became more numerous, pouring into the rookery from every side, and as they settled for the night and disputed the possession of some perch with their neighbors there arose a veritable Babel of voices.

Their usual keen sight dimmed by the gloom, all the birds came to be less shy. A Louisiana Heron sought what was doubtless its regularly frequented perch within reach of my foot; others took adjoining limbs; and, as the crowning event of the afternoon, a Spoonbill and two Snowy Egrets roosted in the same tree with me.

About a dozen Spoonbills' nests were situated in this rookery, four or five of which held fresh eggs; in one were four, in the others, three eggs. These nests were in the mangroves, often near one another, and at an average height of ten or twelve feet above the ground. They were made of larger sticks than those used by the American Egrets nesting near then. As a rule,

\section{Nest and Eggs} the sticks were rather loosely put together, so that the nests were far from carefully made.

The eggs of Spoonbills, as well as their habits and structure, indicate that they are more nearly related to the Ibises than to the Herons. Instead of being blue, like those of.Herons, the eggs are white, or pale greenish blue, more or less heavily blotched with brown at the larger end and with spots or specks scattered over the remaining surface, thus resembling the eggs of the White Ibis. They measure about two and a half inches in length, and one and three quarters in breadth.

The eggs we found in the Cuthbert rookery on March 29 were freshly laid, but we had reason to believe that the birds had been robbed, and that this was a second laying. Audubon says that the eggs are laid about the middle of April, but there are specimens in the United States National 
Museum which were secured on Marquesas Key, Florida, on January I I, I883. Unquestionably, therefore, the birds begin to nest as early as January. 'Dates may be later, as with the Cuthbert rookery birds' second layings, or owing to the variation in nesting-time that sometimes occurs among birds breeding in warm climates, where the necessity for regularity is not so urgent as it is further north, where the warm season is shorter.

On April I7, 19ro, I found a colony of about two hundred pairs of Roseate Spoonbills on Pajaro Island, in Tamiahua Lagoon, on the eastern coast of Mexico, south of Tampico. Most of their nests contained wellgrown young at least a month old, and probably older.

The Young Allowing a month for hatching, it is evident that these birds began to lay about the middle of February.

Spoonbills are covered shortly after birth with a snowy white down, through which one may see enough of their pink skin to give them a reddish appearance; the feathers themselves, however, are not colored. While they are in the nest this plumage, "natal down," as it is called, is followed by what is known as the "juvenal plumage," in which they leave the nest. In general appearance young Spoonbills then strongly resemble their parents, but the head and throat are thinly covered with white feathers, and the rusty marks at the sides of the breast and at the end of the tail of the adult have become pink.

In this Mexican colony four was the usual number of young. They were well-behaved youngsters, and in the absence of their parents rested peacefully in their homes, or occasionally ventured on thrilling excursions of a few feet to the adjoining limbs. But when their parents returned they were all attention and on the alert for food. On such occasions they usually stood in a row on the edge of the nest facing the old birds, and in a most comical manner swung the head and neck up and down. I have seen balanced mechanical toys which would make almost exactly the same motion. The toys, however, were silent, while the little Spoonbills all joined in a chorus of tremulous, trilling whistles, which grew louder and more rapid as the parent approached.

What their parents brought them I could not see, nor, for that matter, could they. But, with a confidence born of experience, the bird that had the first opportunity pushed its bill and head far down into its parent's mouth to get whatever was there. This singular operation sometimes lasted as long as ten seconds, and it was terminated only by the parent which, much against the will of its offspring, disengaged itself; then after a short rest a second youngster was fed, and thus in due time the whole family was satisfied.

\section{Classification and Distribution}

The Roseate Spoonbill belongs to the Order Herodiones and Family Plataleidae; and its scientific name is Ajaia ajaja. It ranges throughout South America and formerly inhabited the whole northern coast of the Gulf of Mexico, and the lower Mississippi Valley, but now exists only in southern Florida.

NOTF-Additinnal copies of this and other Educational Leaflets mav bo obtained for 5 cents each from the National Association of Audubon Societies, No. I974 Brnadway, New York City. 


\section{THE SORA RAIL}

By EDWARD HOWE FORBUSH

\section{The National Association of Audubon Societies Educational Leaflet No. 75}

In the marsh the wilderness makes its last stand. Civilization sweeps away the forest, dans and diverts the streams, cultivates prairie, hill, and meadow, traverses the pond in boats, and destroys the native birds and mammals, but the marsh remains unconquered to the last. Along the Atlantic seaboard, where agriculture and civilization have held sway for hundreds of years, stretches of bog-land yet persist, even within the limits of cities; and here such shy creatures as inhabited them when Columbus

Marshes

Persist discovered America still maintain their homes. Here the great snappingturtle drags its slow length along, here the Bittern may be heard "driving its stake," and here the Rail peers from its age-old fastness-the cover of reeds, flags, and sedges. Man dislikes the quaking bog and the miry ooze, and so it remains a refuge for the light-footed and defenseless ones that can run over its shuddering expanse or crawl in its mud and water.

Rushes, sedges, waving cattails, and lush water-plants in tangled profusion, form a curtain screening the private life of the Rails from human view. We hear sounds from behind this screen, and now and then a "Mud-hen" peeps out; and so we have come to associate them with the steaming summer morass, the pond-weeds, pickerel-weed, and the lily-pads, over which, light of weight and splay-footed, they can run at will.

Some of their notes are such as might be expected to come from a frog-breeding morass; others are as sweet and wild as those of the Whip-poor-will, or of the Solitary Vireo. Rails have some notes that resemble and harmonize with the frog-chorus, such as krek, krek, kuk, $k u k, k u k$, and others more subdued and varied. I may venture to assert that no man yet has fully identified all the notes of all the species of American Rails, and probably no one man ever will. I have heard sounds in the marshes that I could not identify. In 1889 William Brewster devoted two weeks to. an attempt to see a supposed Rail heard in the Cambridge

\section{Mysterious} Bird-voices marshes.' He never saw it, and the voice is still a mystery, although it has been heard many times since and in other places. This bird may have been a Yellow Rail, but twice I have heard a wonderful solo from the marshes, partly original, and partly in seeming imitation of other birds, which, from its quality, I can attribute only to the Sora. This "song" was kept up intermittently for several hours, and showed great versatility; 
some of the notes were frog-like, but most of them were like those of a bird. A common call or song has been rendered ker wec; and the Sora has a high "whinny"-also notes like peeping chickens.

The Rail is a bird of mystery. I always feel like putting an interrogation-point after the name. About the habits of no other common birds do we know so little. The Sora Rail is one of the most abundant birds of North America, and has been sold in the mar-

MarketShooting kets by thousands for more than a century. It breeds commonly, even abundantly, over a great part of the United States and Canada; yet most of its habits, and, perhaps, many of its notes, are still largely its own secret. While floating in a light canoe down the sluggish current of some marsh-bordered river in September you may watch the Sora silently stealing along the muddy margin, poking things with its short yellow bill, and gently jetting its tail; or in tramping along the edge of the marsh you may see one flutter up, just above the grass and reeds, and fly awkwardly, with dangling legs, across some slimy spool, to drop clumsily out of sight again, as in the accompanying picture. This is about all the observant traveller ever sees of the bird. Rails are timid, skulking fowls and pass the greater part of their lives wading under cover of water-plants or squeezing between the grassstems. They have done this so much that their little bodies have become

Thin as

a Rail compressed from side to side, and they can voluntarily shrink in width, so as to push their way between stems apparently only half an inch apart. Hence the proverbial phrase "thin as a rail."

Rails make for themselves dark and winding passages among the reeds, grasses, and rushes, along which they may run swiftly to escape four-footed enemies, and, at the same time, remain concealed from winged foes. They come out into the open when they believe that the coast is clear, with no enemy in sight, or at night, when hawks are absent. The Black Rail has kept its secrets so well that, although a century has elapsed since Americans began to study ornithology, Arthur T. Wayne, in 1904, was the first person to see the mother-bird on her nest. This was in South Carolina. Perhaps some investigator of the future may build a watch-tower in a marsh and study the habits of the marshfolk with a spy-glass, but until something of this sort is undertaken we are likely to know little of Rails' habits. The curiosity of these birds, however, may become of advantage to the observer, as they have been known to approach a hunter lying in wait for ducks Curiosity and peck his clothing, boots, or gunbarrel. A quiet man is to them a wonder, for they are accustomed to associate much noise and movement with all humankind.

The Sora nests about the borders of prairie sloughs, in the soft, dense grasses, or sometimes on a tussock. In the marshes of the East the nest is often placed in a bunch of coarse grass, or among the cattailflags or other rushes. It is sometimes a bulky, arched structure, made 

of weeds, grasses, rushes, etc.; sometimes a slight platform, or a mere shallow basket. Often it is hung among cattails, several inches clear of the water, with a pathway of trampled blades leading to it, while nest and all are screened by the over-arching flags, and, occasionally, one is found in a tussock on the bank of a brook. The eggs vary from six to fifteen in number, and are buffy white, but deeper in shade than those of the Virginia Rail, and heavily spotted with brown and purple.

Nelson says that the parents desert their nests and break their eggs when floods submerge their homes. The young Rails just from the egg are fascinating and supremely comical mites-little balls of down, black as jet, each with a bright-red protuberance at the base of the bill, and an air of pert defiance. It is a very clown! So says Dawson, who came upon a brood just hatching. All took to their heels, except two luckless wights not yet out of the egg. At his approach one more egg flew open, and a little black rascal

Precocious

Chicks

rolled out, shook its natal coat, tumbled off the nest, and started to swim off to safety.

The young of this bird have often been mistaken for those of the little Black Rail. They are certainly both small and sable. When they once leave the nest they are constantly in danger. Most of the larger animals and birds of the marshes, from the Sandhill Crane down to the mink, devour the eggs and young of Rails wherever they find them. In the water, snakes, frogs, fish, and turtles lie constantly in wait to swallow them. They soon become experts in climbing and hiding. They can clamber up and down the water-plants, or run through them over the water by clinging to the upright stems. They swim more like a chicken than like a duck, nodding their little heads comically as they advance. Necessity soon teaches them to drop into the water and dive like a stone to safety.

As the autumn nights grow cooler migration begins. The ancients believed that the Rails passed the winter in the mud at the bottom of ponds, changing into frogs. Their frog-like notes, and the chug with which they sometimes dive, favored this delusion; also, the sudden disappearance of all the Soras on a frosty night seemed suspicious. Some still, moonlit night, after a north wind, the Rails vanished; on the next morning ice covered the marshes, so the explanation that they had dived to escape the ice

Migratory

Habits gained credence. Audubon alluded to this matter in the following passage in Volume $\mathrm{V}$ of his Birds of America:

"The most curious habit or instinct of this species is the nicety of sense by which they ascertain the last moment they can remain at any of their feeding grounds at which they tarry in autunun. One day you may see or hear Soras in their favorite marshes, you may be aware of their presence in the dusk of the evening; but when you return to the place early next morning they are all gone. Yesterday the weather was mild, to-day it is cold and raw; and no doubt the Soras were aware that a 
change was at hand, and secured themselves from its influence by a prompt movement under night."

Now we know that the Rails fly southward after dark. They often dash themselves against lighthouses, poles, telegraph-wires, and buildings, and one has even been known to impale itself on a barbed-wire fence.

The little wings, which erstwhile could hardly raise the birds above the grass-tops, now carry them high and far. Some cross the seas to distant Bermuda, and they occasionally alight on vessels hundreds of miles at sea. They have been taken on the western mountains, even as high as 12,500 feet; in the sage-brush of the desert, and on the cliffs of the Isthmus of Darien.

The food of Rails never has been carefully studied.

Food

We know that they are fond of many kinds of insects and worms, and that they eat snails and other sorts of aquatic life; also parts of water-plants. The Sora, like many other swamp-birds, feeds largely in autumn on the seeds of wild rice. This makes them so fat that they become a dainty morsel for the epicure, and are pursued without mercy by market-hunters and "sportsmen" of all colors, ages, and classes. In the fresh-water meadows they are sorretimes driven from cover by dogs, and many: are shot in this manner.

Shooting them in their slow, fluttering flight in the daytime is about as difficult as hitting a tin can floating down a brook, and a good marksman rarely misses one. The greatest slaughter is perpetrated on the tide-water marshes of the Middle Atlantic States, where gunners shoot

\section{Merciless}

Slaughter

almost anything that flies. When the tide rises high enough to allow small boats to float over the marshes, boats are poled into every refuge of the poor Rails, and, as they seek safety in flight, they are shot down without mercy. Hundreds of thousands are thus killed whenever the tide is high. The negroes of the South pursue a similar sport at night, blinding the birds with torches, and striking them down with poles. This wholesale killing has greatly decreased the Sora Rail in New England, but the species is very prolific, and is still numerous in many marshes in the West and Northwest.

The draining of lakes and marshes for farming purposes, which breaks up their breeding-grounds, will inevitably reduce their numbers still more, year by year, so that stringent protection will be necessary to maintain the species.

\section{Classification and Distribution}

The Sora belongs to the Order Paludicola, or marsh-birds, Suborder Ralli, Family Rallida, and Subfamily Ralline, which includes the Rails and Crakes. It ranges over most of North America, breeds from central British Columbia, and the valleys of the North Saskatchewan and St. Lawrence rivers south to southern California, Utah, Colorado, Kansas, Illinois, and New Jersey; and it winters from northern California, Illinois, and South Carolina, to Venezuela and Peru.

This and other Educational Leaflets are for sale, at 5 cents each, by the National Association of Audubon Societies, 1974 Broadway, New York City. Lists given on request. 


\title{
THE PINTAIL
}

\author{
By HERBERT K. JOB
}

\section{The National Association of Audubon Societies}

\section{Educational Leaflet No. 76}

Along the wild shores of Lake Winnipegosis, in northern Manitoba, in a region known as the Waterhen River Country, extends a wide belt of bog and meadow, back of which lies the unbroken, primeval, poplar forest. This forest abounds in moose and deer, and there covies of Ruffed Grouse whir up before one into the low trees with surprising frequency, and gaze curiously at their first sight of man. The interminable strip of marsh by the lake harbors throngs of waterfowl of many kinds. Much of it is overgrown with a bewildering maze of reed, rush, and cane, dissected by narrow, winding, waterways, here and there uniting in open ponds. This is the

\section{Manitoba} Marshes home of such birds as the various Grebes, the Loon, Black Tern, Bittern, and the Canvasback, Redhead, and Ruddy Ducks. Other parts are more open and meadow-like. In one part this meadow is alkaline, and a series of shallow, brackish ponds and pools with nutdy margins extends for many miles. Although the clonds of mosquitos bred in these pools are dreadful, compensations are present. Along these shores, late in May, feed tribes of migratory shore-birds in elegant nuptial plumage-Sandpipers, Plovers, the Lesser Yellowlegs, some Marbled Godwits, an occasional Hudsonian Godwit, an American Avocet, or a pretty party of Northern Phalaropes, swimning like tiny geese.

Out in the middle of the pools flocks of ducks disport themselves-all breeding in the vicinity. They are not very wild, and one may readily approach them behind tall grass or bushes, and, with a field-glass, see each one as clearly as though it were actually in hand. They are of the kind which prefers the shallow, open pools of the prairie slonghs. The males are in gaudy spring livery. All swim in mated pairs, each of which has its nest hidden rot far away in the old grass of the past season. Some are still laying eggs, and the partial sets are cleverly covered with a blanket of down plucked by the female from the under surface of her body.

\section{Domestic Life}

Others have covered their brooded eggs, and are out for a restful swim and luncheon with the lordly head of the house, who is too aristocratic to take his turn on the eggs, and will soon forsake his spouse to moult off his finery in remote recesses of the tangled bog. Conspicuous by large size among this company are some Mallards, contrasting sharply with the small Blue-winged and Green-winged Teals. That gaudy drake of moderate size, and his plain spouse, both with enormous bills, are Spoonbills or Shovelers. A few Gadwalls and American Widgeons also 
are to be seen. Yonder white-backed Lesser Scaups seemingly should be with their deep-diving relatives, the Canvasbacks, but they nest in the grass at the edge of these shallow sloughs.

But what are those slender, elegant ducks, long of neck, agile of movement, the male an exquisite gray and white, with a long spike of tail held up carefully out of the water? At last I have found the Pintail; and it is well worth a journey of more than two thousand miles to visit it in its summer home. It is a duck of distinction, clad with grace and beauty, with sprightliness of disposition, and a rakishness of form which together prove it of distinguished lineage. It is the greyhound of the anatine world, rather than the mastiff or collie. One might even

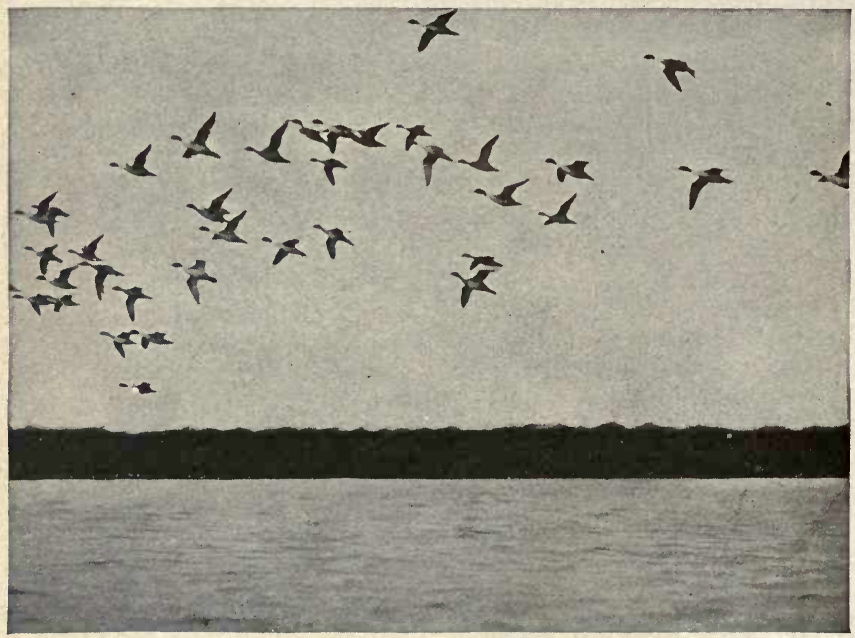

PINTAILS FLYING NEAR MARSH ISLAND REFUGE, LOUISIANA

Photograph by H. K. Job, New Year's Morning, 1914

venture to term it the "sportiest" of the ducks-active, alert, possessed of real "style"; and, although moderate in weight, of sufficiently good food-quality. Though fairly shy and watchful, it is not hard to surprise it in the small reedy pools which it often frequents. The flock is likely to bunch when alarmed, and travels with ranks compact.

In one of these alkaline ponds, on a small grassy island, where grew also a few low bushes and clumps of weeds, I found a nest, probahly of one of those pairs I had watched through my glass. It was the fifth of June, a cold, stormy day. I had waded to the island, sinking to the tops of long boots, and had begun to beat about, hoping to start some duck from her nest. Suddenly there was a flutter and a spring, and a grayish duck with sharp tail-feathers shot into the air, and hurtled 


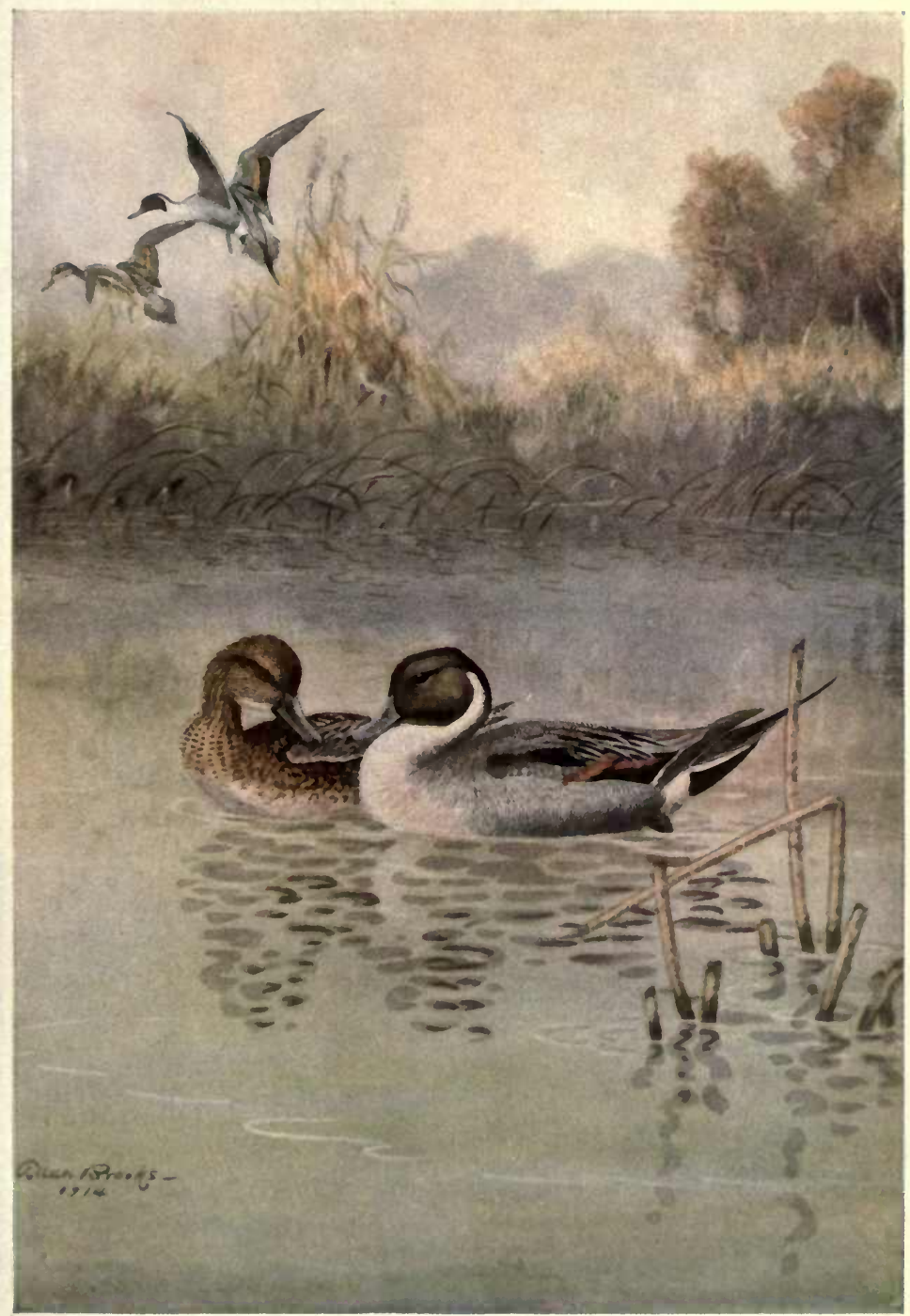

PINTAILED DUCK 

off, on her own wings and on those of the keen northeast wind. What other duck of these marshes than the Green-winged Teal or the Pintail could quite hit that pace! She had protected her eight eggs from the rain until the last possible instant, and then made up well for lost time.

The nest was typical, a rather frail affair, about the size of the crown of a hat, situated in a slight hollow amid not very tall grass and weeds, quite near some low bushes-a mere little rim of dry grass, lined with a moderate amount of grayish down. The eggs were rather small and narrow for the appar-

A Frail Cradle ent size of the bird, and were light buff, with a decided greenish or olive hue. This greenish tinge distinguishes them from the white and creamy eggs of the Gadwall or Widgeon, and from the brown eggs of the Scaup, all of similar size; while their size differentiates them from the eggs of the other ducks of that region. Hence an experienced person may pretty surely identify a Pintail's eggs even without seeing the owner.

The number of eggs in a set is likely to be fewer than in the case of the other ducks mentioned, nor is the maximum as large as with some. I have found probably about thirty nests of the Pintail. In records of twenty-one of these which were accessible, two had five incubated eggs, three had six, six had seven and eight, three had nine, and only one had ten. Its other neighbors very seldom have less than eight, nine to eleven being common. Of large sets, in the case of other species, I have found a Golden-eye with sixteen, a Ruddy Duck, Redhead, and Canvasback each with fifteen, and a Redhead with the surprising number of twenty-two, every one fertile.

\section{Large \\ Families}

No duck is less particular about nesting near water than this species. Though we may see the pair swimming in the sloughs during the nestingseason, the nest may be almost anywhere-perhaps on a dry island or elevation in a marsh, but, as likely as not, far back on the sun-parched prairie, where I have found nests a mile from the nearest water.

The Pintail and the Mallard are the earliest of the ducks to lay eggs. The ice does not disappear from those big lakes of the far Northwest till about the middle of May, but by the 25th of June I have caught young Pintails two months or more old, showing that the eggs were laid as early as the first week in April, when the country was still in the grip of winter. Most sets, however, seem to be laid early in May, though some are not forthcoming till late in the month, very possibly after an early set had been destroyed.

\section{Wild \\ Ducklings \\ at Home}

The downy young are very different in appearance from the young of other "river" ducks. Instead of being yellow and brown they are brownish black, mottled with whitish above and with grayish white on the underparts.

These earliest broods are able to fly by the middle of July, whereas the late-breeding Scaups and Scoters do not mature their young before the first week of October. By early August there are considerable flocks in the prairie sloughs of young Pintails and Mallards. Having had as 
yet no knowledge of man they are then quite tame, and it is great fun to creep close up to them with the reflecting camera as they feed in the small ponds in the marsh. Away they go with a thunder of wings when one steps out from the rushes on the edge, and one may get splendid "shots" just as they spring into the air. Even thus early they are well practised in the long standing jump.

Maturing so soon, they begin to migrate rather early, so that flocks appear south of their breeding-range in the Northern States early in September. Yet they are hardy, for some winter as far north as Long Island Sound, and in various localities they linger until ice fornis. They winter on our southern coasts, and down through Migration Mexico to Panama. Early March sees them moving back through the United States again, and by the last of the month some are on their more southerly breeding-grounds. They breed mostly in the interior and western districts, especially in the prairie region northward from Iowa and Nebraska, commonly in North Dakota, and thence northward to the Arctic Coast. Cosmopolitans, they are well known in Europe also.

Though not given much to quacking, like the Mallard and the Black Duck, they utter now and then a subdued quack, but more often express themselves in a soft chattering or low whistle. For the most part I have lieard little sound from them, but they are said at times to be noisy.

Like most ducks in fresh water, the Pintail devours many kinds of insects and small aquatic creatures, snapping eagerly at flies and mosquitos on the wing. It is fond of succulent water-plants, such as wild celery, eating both roots and seeds; and even of nuts, where these grow not far from the water. Ponds are preferred to Food - streams, and in winter grain-fields, meadows, and even the prairies, have varied attractions as feeding-places.

In the West, where there are prairies and marshes, this is one of the most abundant ducks, but in the East it is rather scarce. There, fearful of ever-present persecution, the few that do come to us slip so furtively at night into ponds and meadows that few besides the keenest of gunners detect their presence. How different seems the harried fowl in the hunting-season from the beautiful "greyhound of the air" on its breedinggrounds! Would that the new era of Federal protection might make more abundant everywhere this beautiful, graceful wildfowl.

\section{Classification and Distribution}

The Pintailed Duck belongs to the Order Anseres, the Family Anatida, Subfamily Anatince, and the Genus Dafila. Its scientific name is Dafila acuta. It ranges throughout the western half of North America, breeding from Nebraska and northern Illinois north to Hudson Bay and Alaska, and westward to the Pacific Ccast. It occasionally visits the North Atlantic Coast in migrations; and winters from British Columbia and the Missouri River Valley southward. 


\section{THE CROW}

By T. GILBERT PEARSON

\section{The National Association of Audubon Societies Educational Leaflet No. 77}

With the approach of winter, the country loses its charm for many persons. The green of the fields and the riotous verdure of the woods are gone, and the brown expanses of dead grass and weeds are relieved only by the naked blackness of the forest trees. This, however, is a splendid time to go a-field to look for birds. If the wild life is less abundant now, even more sparse is the human life, and so you will have the country more to yourself.

One of the birds very sure to be seen and heard in a walk is the Crow, for many of his race spurn the popular bird-movement southward in the autumn when the North begins to freeze. I like him best at this time of the year. There is no young corn for him to pull now, no birds' nests to pilfer, and

In Winter no young chickens to steal. He has few places where he can hide, and his black shape looms sharp against the snow-clad hills. I see him sometimes in January as we come down the Hudson together-I in a pullman and he on an ice-floe.

Now and then I see him strike into the water with his beak, or fly a short distance to a rock or exposed gravel-bar, where things that die and foat in the river become stranded. Once I surprised him in the woods, where he had attacked an old, rotten pine-stump. He had torn half of it to pieces and the fragments lay scattered on the snow. Perhaps he was seeking certain insects taking their long winter sleep, or he may have been after beetles. To fathom the mind of a Crow takes not only persistent effort but considerable imagination.

At this season Crows are highly gregarious creatures; especially at night, when they sometimes collect by hundreds or thousands in some favorite grove. Some years ago there was such a roost near the town of Greensboro, North Carolina. It was resorted to for several years in succession, and

\section{Great Roosts} was a source of no end of wonder to the people of the surrounding country. The roost occupied several acres in a grove of second-growth, yellow-pine trees. By four o'clock in the afternoon the birds would begin to arrive, and from then until dark thousands would come from all directions. Singly, by twos and threes, in companies of ten, twenty, or a hundred, they would appear, flying high over the forest trees, driving straight across the country, pointing their line of flight as direct as only a crow can fly to their nightly rendezvous. Early in the morning they were astir, and if the day was bright it would not be long until all liad departed, 
winging their way over the fields and woodlands to widely scattered feeding-grounds.

Often I watched them come and go, and one night walked beneath the sleeping hosts and shouted aloud to them; but they did not heed my presence, nor was I ever able to arrive at any reasonable explanation for their nightly assemblies. Surely they did not gather thus, as some writers have suggested, purely because of an impulse for sociability and for love of their kind, for I saw them quarreling among themselves on many occasions.

Especially do I recall one evening when, as I watched them coming to roost, I became conscious of an unusual commotion among a flock of

Killing a

Comrade eight. One evidently was in great disfavor with the others, for, with angry and excited cawings, they were striking at him in a most unfriendly manner. The strength of the persecuted bird was all but spent when I first sighted them, and when, perhaps two minutes later, the fleeing one sustained a particularly vicious onslaught, it began to fall. It did not descend gradually, like a bird injured while on the wing, but plunged downward like a falling rock a hundred feet or more into the top of a large pine-tree, and, bounding from limb to limb, struck the ground but a few yards from me. When I picked it up I found it to be quite dead.

When the pursuers saw their victim fall their caws abruptly ceased, as if the birds were shocked at what they had done; and, turning, they departed silently and swiftly, all in different directions. I wonder if they were executioners performing a duty for the good of the clan? Perhaps they were only thugs, sandbagging a quiet and respectable citizen on his way home!

Birds are particularly subject to disease in winter, and many perish from affections of the throat and lungs. Crows are attacked at times by a malady called roup, and hundreds of the bodies of those that have died from it may sometimes be found on the ground beneath a roost. -Wild birds have no doctor, who can come at the first signs of an epidemic and vaccinate them against its ravages.

Crows are among the earliest birds in spring to build their nests, and usually freshly laid eggs may be found during the first half of April. These eggs are bluish green, thickly marked with various shades of brown, so that they blend admirably with the canopy of green pine-

Nest and Eggs needles among which the nest is so often placed. To climb to a Crow's nest is often quite an undertaking. Sometimes, it is true, the situation may be only thirty or forty feet from the ground, but I recall once climbing to a Crow's nest in Florida, which, by actual measurement with a cord, was ninety-one feet in the air. The nests are heavy, compact structures, made of sticks and twigs, and lined with grapevine-bark, grass, and sometimes with moss. The old birds are usually very quiet when in the immediate neighborhood of their nest, and frequently the only evidence one wili 
CROW

Order-PASSERES

Genus-Corvus
Family-Corvide

SPOCIOS-BRACHYRHYNCHOS 

have of the fact that they are near him is seeing a Crow fly swiftly and noiselessly away among the tree-tops.

For hundreds of years farmers have regarded the Crow as one of their most annoying enemies. This is chiefly because the Crows dearly love to pull up corn shortly after it has sprouted. They do this to get the grain of seed-corn, which has become softened by contact with the soft earth. Then, too, as the grain begins to germinate, the starch it contains turns to sugar, and thus there is made a dainty . tidbit which is quite to the liking of a hungry Crow. Very naturally, therefore, the farmer seeks to rid the

\section{His Foes} neighborhood of these black-feathered visitors. Time and again he takes his gun and sallies forth; but no sooner does he enter the field where the

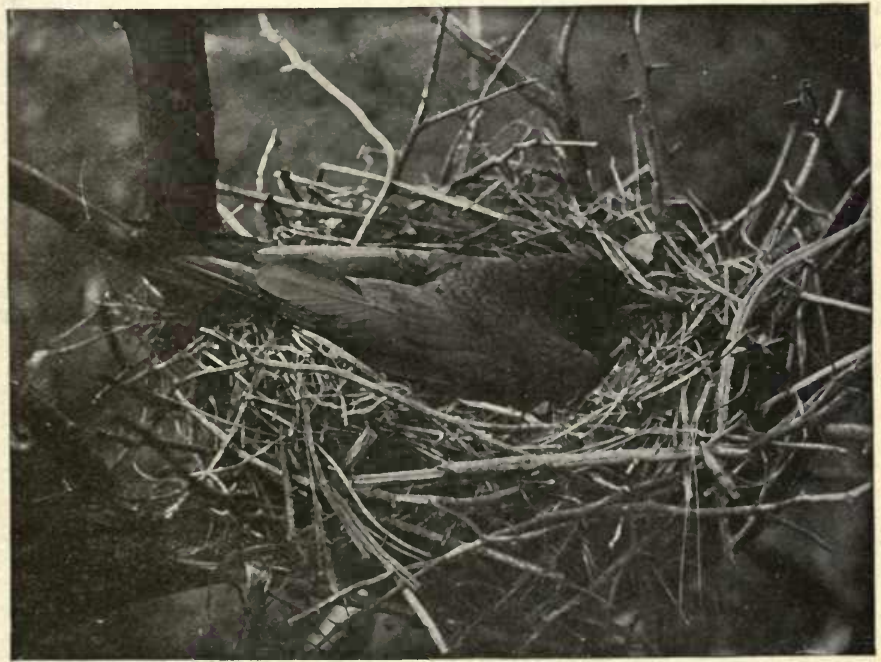

A CROW BROODING UPON ITS NEST

birds are feeding than an old Crow, which has established himself as a sentinel on some tree or fence-stake, gives a warning "caw" that all of his friends understand, and in a moment the entire flock takes flight to the nearest woods, where they calmly await the departure of their disturber.

Now and then the farmer or his boy, by hiding among the trees or along a fence, succeeds in shooting a Crow. When this is accomplished, the bird's body is often tied to a pole, which is then set up in the field as a warning to the bird's fellows of the fate that awaits them if they persist in returning. A chorus of jeering car's is often the only answer the farmer gets for his trouble, for let no one ever forget that the Crow is about the Smartness smartest bird of which we have any knowledge. If he were not a bird 
of most unusual wisdom, his race would long since have passed away. Think of the hundreds of thousands of farmers who, through the centuries, have tried every possible means of destroying these birds! No law in any State protects them, and many times bounties have been paid for their heads, thus offering a special inducement to men to kill them. Guns, traps, poison, and destruction of their nests have all alike been in vain, for the Crows live on in apparently undiminished numbers.

As a matter of fact, the Crow is not altogether a bad bird, and if he were understood better I have little doubt that he would have far more friends than foes. He eats a great many harmful Insect Food insects, and in this way makes amends for his sins in the cornfield. May-beetles, June-bugs, and other insects of a similar character, are eaten by Crows in great numbers during the spring and early summer. Some observers state that baby Crows are fed to a very large extent on this kind of diet. Crows like grasshoppers, especially in the spring, and annually consume large quantities of them. They eat also, among other objects, such queer foods as frogs, toads, and young turtles, and even small snakes find favor in their eyes. The wild fruit they take is mostly such as that of the dogwood and the sour gum. Sumac-berries of different kinds are eaten. In fact, the Crow will sample almost anything that looks as if it might be good to consume, such as frozen apples, pumpkins, turnips, potatoes, or any other fruit or vegetable that may be discarded and left to lie in the orchard or field. In cold, snowy weather, food sometimes becomes very scarce. On such occasions Crows will feast on any dead animal to be found, such as a horse or a cat. They sometimes go down to the shore and hunt for clams, crayfish, and the bodies of dead fish that have washed

A Scavenger ashore. This practice, however, may more often be observed in the Fish Crow, a bird slightly smaller than our common Crow, and found chiefly along the sea-coast, and about the larger lakes and water-courses.

The Crow, in its various forms, has a wide distribution throughout North America; and there is hardly a boy or girl who does not know its cry, or who is not familiar with the sight of the big, black fellow flying over the fields or resting for a moment on the top of a tree by the roadside. It is undoubtedly the most common and most generally known bird in the United States.

\section{Classification and Distribution}

The Crow belongs to the Order Passeres, Family Corvida, Subfamily Corvina, and Genus Corvus. Its scientific name is Corvus brachyrhynchos. Its range in summer covers the whole continent northward to Newfoundland and Central Quebec in the East, and southern Mackenzie in the Northwest; and it remains in winter throughout the whole United States and southern Ontario. In addition to the eastern type, two subspecies are recognized, $C . b$. hesperus, of the Rocky Mountains and Pacific Coast, and C. b. pascuus of Florida.

This and other Educational Leaflets are for sale. at 5 cents each, by the National Association of Audubon Societies, 1974 Broadway, New York City. Lists given on request. 


\section{THE LOON}

By ARTHUR H. NORTON

\section{The National Association of Audubon Societies Educational Leaflet No. 78}

One's introduction to the Loon is likely to be through the medium of its voice, and it may seem to be the incarnation of the spirit of the wilderness-waters, for its abiding-places are in the solitude of lakes rimmed with clark forests and distant blue hills, or on the broad bosom of the tossing sea. Like the spirits of old legends, it seems never to sleep, but to be ranging these realms both day and night, sending abroad wild, loud notes at all hours.

Better acquaintance with the Loon will show it to

\section{A Spirit of Solitude} be a large, beautifully plumaged bird, remarkable for its masterly accomplishments; and although its notes often have a sad, or even a despairing sound, it is a happy, self-reliant creature, demanding our admiration rather than our pity.

The Loon spends its life afloat, and no more powerful swimmer can be found in the bird-world. Its heavy, flattened body, half-submerged when swimming, affords little leverage to the driving blast, while the great webbed feet,

Swimming and Diving operated by powerful muscles, drive it onward against wind and wave. Matchless swimmer though it is, it is an even more wonderful diver, for it must chase and capture fishes in their own element. If pursued by man, or if attacked by an eagle, it instantly takes refuge beneath the surface, speeding away to a safe distance, now and then merely thrusting its head above the surface to catch breath, and again diving and speeding onward to a place of safety.

Many a Loon has escaped death by ducking at the flash of a gun, ere the shot could reach him. Though quick in diving, head foremost, it has the remarkable ability to sink its entire body beneath the surface without visible effort. This faculty belongs to several other diving-birds.

Trusting extensively in its powers of swimming over and under water to escape its enemies, and to procure its food, it nevertheless is a strong flier, although progressing with apparently labored movements, and in calm weather finding great difficulty in rising from the water. It must rise

Powerful

Flight against the wind, so that the pressure of the breeze against its narrow pinions may assist in raising its weight from the surface. Once on the wing it may perform long journeys, as it does on its migrations, which take it many miles overland to and from the lake where it makes its home. On these flights it sometimes sends forth a defiant note, 
attracting attention to its speeding form far above tree-tops and hills. In flying over the ocean, it seems to feel that its true safety is in the water, for a sudden shout or startling sound will often cause it to drop near the surface. This habit is taken advantage of by gunners, as the bird flies overhead.

The Loon leaves its secluded lake within the realm of the frostgiants, sometime after the breeding-season, and speeds away to spend the icy months on the ocean, where, amid ceaseless currents and toppling waves, it finds an abundance of food, and, with hosts of other sea-fowl, rides out the winter's fury:

With the return of spring, and the warming of its stout heart toward

Home and

Family its mate, it again seeks the lake and resumes its family cares. Year after year it returns for a nestingplace to the same tiny islet, floating tussock (or it may be to a muskrat-house), to some sandy beach in a sheltered cove, or perhaps to a point of land where turf and water meet. Sometimes the nest is fully open to view, sometimes well hidden by bushes, or perhaps a mere hollow without lining; but it may be slightly or, occasionally, well lined. Rarely an elaborate nest is built in the shallow water, raised above the level of the early summer floods, and such a nest is left high and dry when the water of the lake recedes in the summer drought.

The eggs usually number two, but sometimes only one is laid. They are about as long as goose-eggs, but smaller in diameter, and are rich olive-brown, more or less marked with spots and lines of a deeper color. They hatch in about a month.

The baby Loons are clothed in soft down, black above, white below. In a few hours they bid farewell to the nest, and are conducted out upon the broad lake by their parents. Here their youth is spent in alternately swimming feebly, and in riding upon their parents' backs. Audubon says that the young are "fed by regurgitation for about a fortnight and then are fed with particles of fish, aquatic insects, and small reptiles, until they are able to maintain themselves." The deep love of the Loon for its nest and young is manifested in acts of solicitude when these are approached, and in marks of affection in fondling and guiding their weak offspring.

The Loon manifests uneasiness before a storm. Perhaps it dislikes the splashing spray, or maybe its savage spirit is

\section{Sensitive to}

Storms stirred to depths of exultation by the turmoil of wind and wave, for, with the rising gale, the bird becomes especially noisy, sending its powerful voice echoing across the water with great frequency. The performance seems contagious, for every Loon within reach of that penetrating tone raises its voice to answer, and then it may seem to a man listening that the confusion of tongues is again at hand.

The storm abated, and the sun again shining upon the water, the Loon finds life easy, and after washing its beautiful plumage with scrupu- 


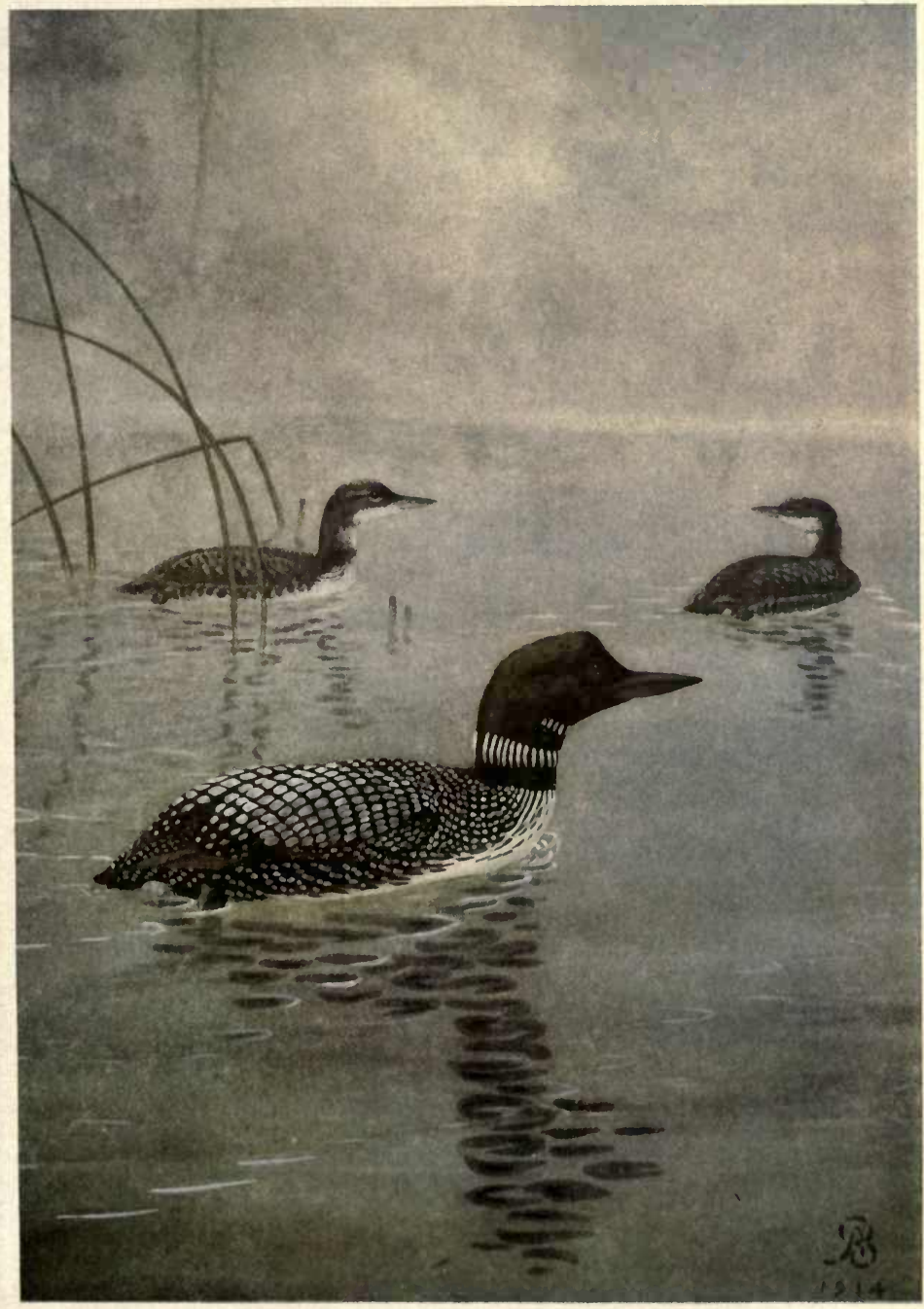

LOON

Order-PYGOPODES

Genus-Gavia
Family-Gavilde

Species-1MMBR

National Association of Audubon Societies 
lous care, and dressing each feather with oil from the gland above the base of the tail, it finds time to play, for, although a veritable savage, the Loon is possessed of social instincts and often indulges them.

Frequently little parties of two to half a dozen or more may be seen racing across the water. Half flying, half swimming, they dash over the smooth water at great speed, forward and back, again and again. Sometimes one or more may chase another, which dashes onward and suddenly plunges beneath the water to escape pursuit; perhaps it suddenly reappears close to another bird, which, catching the spirit of the play, acts as if seized with panic, and rushes away, pursued by others of the party. While at these sports Loons may be very noisy or nearly silent.

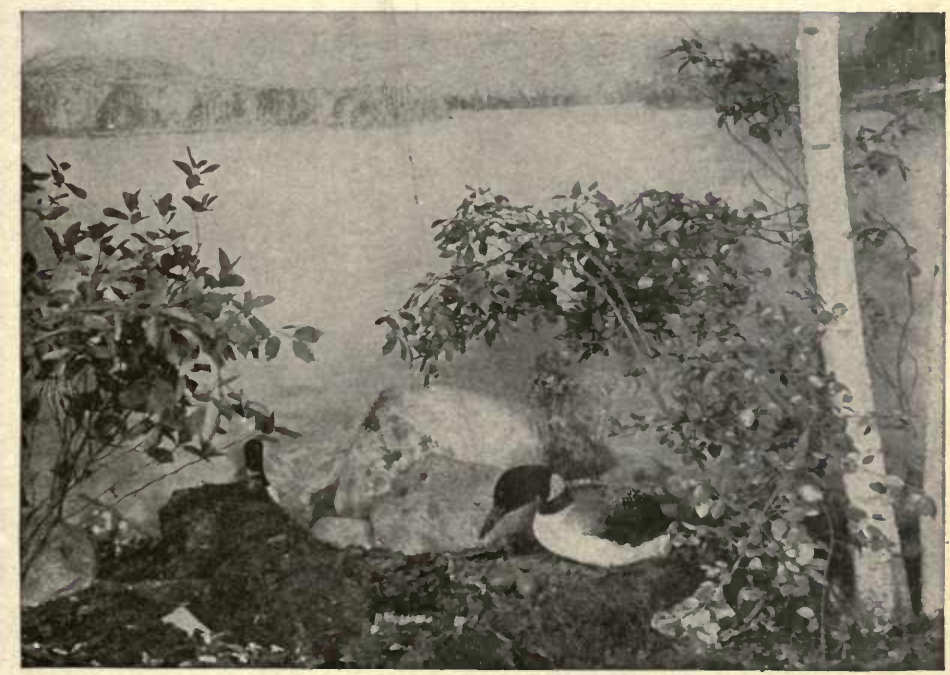

A LOON'S HOME ON LAKE UMBAGOG, MAINE

From the Group in the American Museum of Natural History, New York

The voice of the Loon is loud, and of volume sufficient to ring above the din of storm and surf, or to echo far and wide to its family or friends over the wide lake, or across spaces of the boundless sea. Its calls are varied, fitting its different moods, and expressing no mean range of emotions. Like some other birds, this one is decidedly inquisitive, and may be decoyed near an ambush by alternately waving and concealing a small cloth on a short rod. It is said that anything, as a small mirror, that will reflect a flash of light will also attract it, and an imitation of its voice will frequently have the same effect.

The beautiful plumage of the Loon lias been in demand for millinery purposes; and the Indians and Eskimos tan its skin for the manufacture 
of garments and bags. These people also eat its coarse, rank flesh, a habit which T. Gilbert Pearson says is often indulged in by the natives of the coast of North Carolina. Few, however, of the number killed by white men are eaten.

The food of the Loon consists largely of fish, chiefly, no doubt, of the smaller and more worthless species. Yet the fact that it is a fisheater has brought condemnation upon it from fish-culturists, and that without a trial. Of the species, of fishes naturally occurring in a given lake not more than one-half are food-fishes for man, and only one-fourth may be called game-fishes.

Dr. William C. Kendall, scientific assistant in the United States Bureau of Fisheries, has written: "In large lakes

A Fish-Eater my observations lead me to believe that it does little or no harm. In most lakes salmon and trout are mostly too large for the Loon to trouble, and it restricts its diet to the smaller, surface-swimming and shore fishes, such as smelts, chubs, etc."

The possibility that the Loon may render a service to conservers of game-fishes, by holding in check in some degree the destroyers of fish-eggs, or in destroying the fishes affected with contagious gill-fungus and other diseases, has never been considered. Unquestionably it is the weaker specimens of such fishes as are eaten that constitute the greater part of the Loon's diet. On the other hand some, as the suckers and horned pouts, are very destructive to the finest game-species, eating large quantities of their eggs, while themselves of little value as food or game.

Audubon says of its diet: "Fishes of numerous kinds, aquatic insects, water-lizards [salamanders], frogs, and leeches have Varied Diet been found by me in its stomach, in which there is also generally much coarse gravel, and sometimes the roots of fresh-water plants."

Its diet is thus shown not only to be more varied than most persons acknowledge, but also in this respect it is without doubt beneficial. Aquatic insects large enough to attract the attention of the Loon are predacious, and in some instances demand active measures for their suppression in fish-ponds, and in this respect the services of a hungry Loon would be welcome.

\section{Classification and Distribution}

The Loon belongs to the Order Pygopodes, Suborder Cepphi, Family Gaviida and Genus Gavia. Its scientific name is Gavia immer. It inhabits the northern part of the northern hemisphere, and in America breeds throughout the mainland of Alaska, on the islands of the Arctic Sea, in Greenland, and throughout Canada and the northern border of the United States. It winters within the United States and on the adjacent oceans.

This and other Educational Leaflets are for sale, at 5 cents each, by the National Association of Audubon Societies, 1974 Broadway, New York City. Lists given on request. 


\section{THE TOWHEE}

By T. GILBERT PEARSON

\section{The National Association of Audubon Societies}

\section{Educational Leaflet No. 79}

Not all birds possess strong personalities. Just as among a people there are many who are neither particularly good nor bad, handsome nor homely, brilliant nor stupid. They play an important part in life, to be sure, but they do not attract any great attention nor arouse, on the part of the observer, any special interest or enthusiasm. We all know such persons, and I dare say most of us have made the acquaintance of such birds now and then.

The foregoing statement, however, does not describe the Towhee, except in a negative manner by calling attention to the fact that it does not belong to the mediocre class, for it is a bird of distinct personality, being endowed, in a very large way, with what we may call "character." The male

A Strong Character is especially striking in appearance, and both he and his mate are filled at all times with an energy and bounding activity that challenge the attention and admiration of everyone who is so fortunate as to meet them.

One cannot watch the Towhee (or "Joree," as it is usually called in the South) without imbibing some of the purposeful energy which the bird imparts to its every movement. The ambitious and slothful alike may receive inspiration and wisdom by considering its ways. I am particularly fond of the Towhee, and have long counted its friendship among my most cherished possessions.

It is about the tenth of April when this bird is usually first seen in the latitude of New York. In rare instances it has been recorded in the winter as far north as Massachusetts, but such cases are very exceptional. Virginia is usually the extreme northern limit of its winter sojourn.

As a rule it is not quite so trustful of mankind as are some of our better-known lawn and garden species, as, for example, the Robin and House Wren; nor is it one of those shy denizens of forests and open fields that rarely venture into a city. In fact it occupies a somewhat middle ground, and to

A WorldlyWise Bird

a more or less extent flits between these two groups, and seems fairly well at home in either situation, as might be expected of so well-bred a bird-of-the-world.

Its occurrence in town, however, wotild appear to be more common in the autumn than the spring. It seems to prefer to investigate 
the abodes of man during the period when it has no pressing domestic duties and responsibilities. When nesting-time arrives, therefore, it is best to seek for it along hedge-rows, or beside old fences half concealed by shrubbery, from the depths of which it will announce its presence by its sharp, clear cry chewink. Abandoned fields, where briers and bushes have sprung up, are also favorite abiding places for the Towhee.

One summer day, as a member of a Harvard botany class, I journeyed some miles out of Cambridge, and afoot began a rather laborious climb up the somewhat steeply sloping side of Blue Hill. As we advanced, the trees decreased steadily in size until, perhaps three-fourths of the way to the top, they became so scraggy that in many places Its Song they had much the aspect of bushes. This change in the condition of the vegetation must have been due largely to the poor quality of the soil, as the altitude was not great. We studied many plants that day, many of which I have forgotten, but I do remember with great distinctness the songs of Towhees, which with marvelous clearness rang from the topmost bough of many a stunted tree.

This is the kind of situation it invariably occupies when singing. The Nightingale may sing from the depths of its myrtle-bush, the Veery from the bough of its favorite oak, and the Gnatcatcher from its nest, but, like the Winter Wren and the Nonpareil, the Towhee must occupy the highest twig of its chosen sapling or bush, before it flings to the summer winds the melody of its notes. Its song is not a remarkable performance when compared with the singing of many birds, but it is vigorous and appealing. The song of the Towhee is the passionate cry of a love-sick bird, who will not take "no" for an answer. Ernest Thompson Seton has told us what it says. He asserts that the bird plainly shouts, chuck-burr, pill-a-will-a-will-a.

The Towhee's nest is often situated on the ground, though sometimes we may find it in shrubs or low bushes. Even when built in a bush it is always near the earth; in fact $I$ have never found one The Nest at more than a foot of elevation. It is usually made of a collection of dead leaves, strips of grape-vine or other bark, and occasionally a few twigs. The lining appears always to be made of fine, dead grasses. It is not covered over like the nest of the Bob-white, 'Meadowlark, Oven-bird, and some other ground-nesting species, and is protected from the rays of the sun and the eyes of the curious only by the twigs and leaves of the bush in which it is hidden. Although fairly ample in size, it is in reality rather a frailly built cradle, and usually goes to pieces during the rains of autumn or in the winter storms.

As may be noticed from the accompanying colored illustration, the female is less highly colored than her mate. This is the case with a great many kinds of birds, and it would appear that when kind Nature made them, she had in mind the fact that the mother-bird would do most of the brooding; and that while on the nest her somewhat duller 


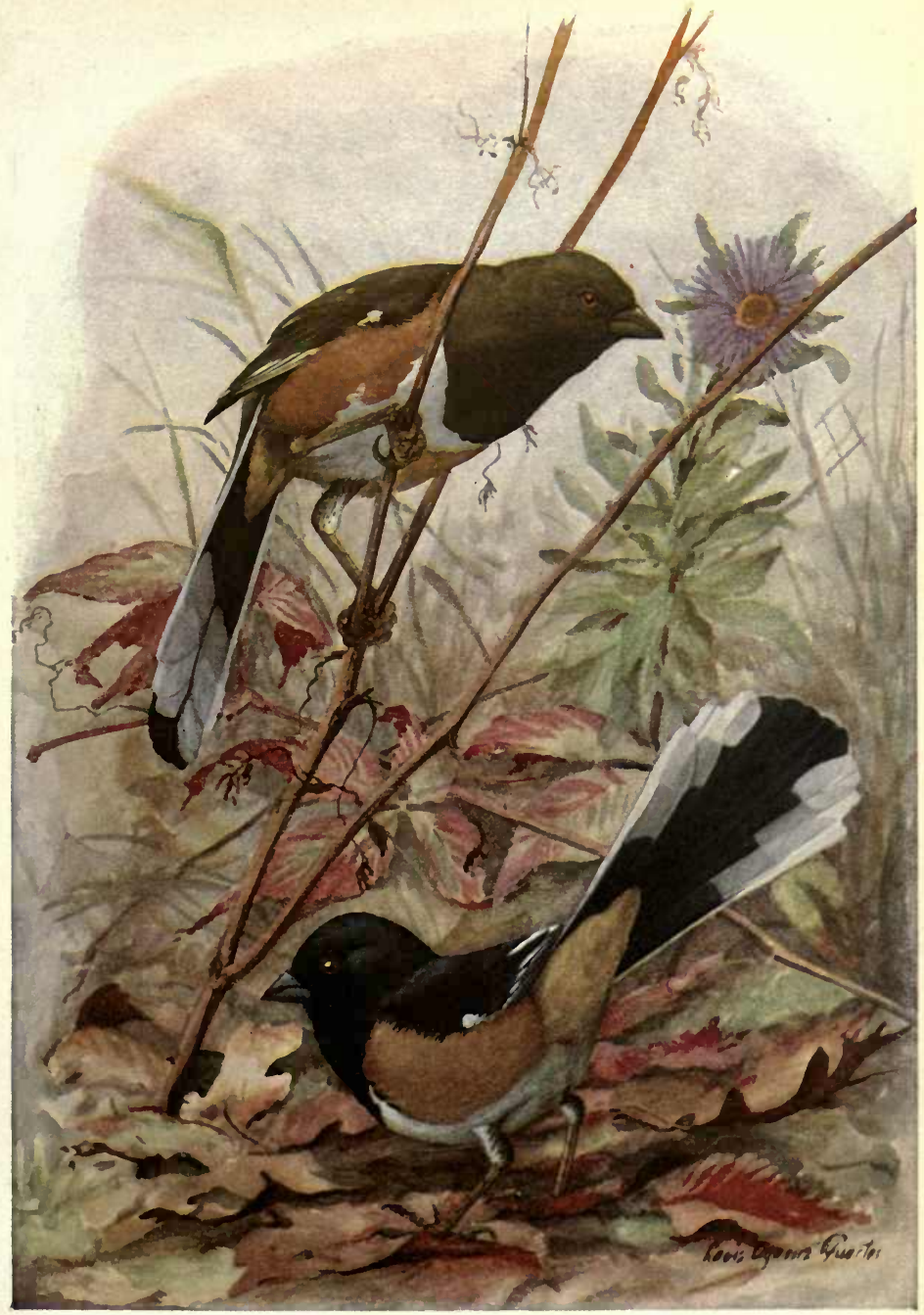

TOWHEE

(Upper flgure, female; lower flgure, male)

Order-PASSERES

Genus-PipiLo
Family-FriNGILLID.e

SPECIES-ERYTHROPF:THALMUS

National Association of Audubon Societies 

coat would not be so noticeable to enemies, which, with claw and beak and tooth, are ever afield on the hunt for little birds. She seems to know how well her coloring protects her, and sometimes one may approach to a point where the hand may almost be laid on her before she takes wing.

Four or five white eggs, finely and evenly spotted with dark red, are laid, usually in May. When one approaches the nest, especially after the eggs have hatched, the parents will immediately appear, and flitting about on the ground or from bush to bush, will anxiously voice their alarm.

The Towhee has one unfortunate weakness - it allows itself to be imposed upon by the Cowbird. The happiness of many a Towhee home is ruined by this dark destroyer of wild-bird life. The Cowbird, which makes no nest

An Imposter of its own, often lays one or more of its eggs in the Towhee's nest, where they are allowed to remain. The young Cowbird grows rapidly, and often crowds some of the young Towhees from the nest. Later,

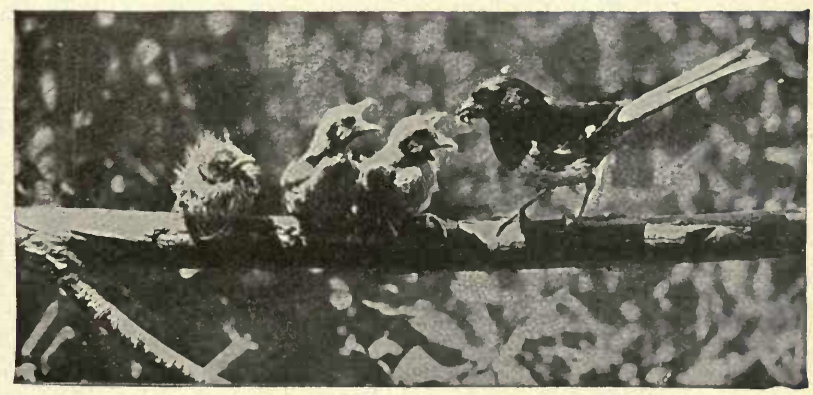

TOWHEE FEEDING THE YOUNG COWBIRDS

when the fledglings leave the nest together, we may sometimes sce a mother-Towhee engaged in the care of a young Cowbird-imposter while giving attention to her own young, as may be seen in the picture on this page, which was made from a photograph.

Some birds feed entirely on fish. In winter, spring or summer, it matters not, they must have fisl. Should the ice form over their usual fishing-places they fly away to where the water is open and fish may be obtained. Other birds eat only insects. Often they are not choice in the kind of insects they have, but almost any kind that has wings and can fly these air-feeding hirds seize and devour. Our Towlice, however, is nearly omnivorous. Edward Forbush, who has spent a great deal of time finding out just what birds eat, tells us that Towhees are fond of ants and of a

\section{Varied Fare} great variety. of beetles. They also eat hairy caterpillars in great numbers. Those found in the neighborhood of gardens, or of fields under cultivation, frequently flit along the ground among the vegetables or grain in 
search of cabbage-worms, potato-bugs, and such other small creatures, many of which are destructive to crops.

It will thus be seen that the Towhee is a very useful bird to mankind, and should receive the most careful protection by everyone. In fact, in most States where this bird is found it is protected by law, and anyone found killing a Towhee is liable to fine or imprisonment and it is right that this should be so.

They eat also such things as grasshoppers, cockroaches and flies, and perfectly adore the long juicy bodies of earthworms. It is for this sort of food that the Towhees search so diligently on the ground in a thicket, where we may hear them scratching among the fallen leaves and throwing them about with an energy and vigor surprising in a bird which measures only about eight and a half inches in length.

John James Audubon, the great naturalist and artist, who was such a close observer of birds, in writing of the Towhee said: "The young leave the nest long before they are able to fly, and follow the mother about on the ground for several days. Some of the nests of this species are so well concealed that in order to discover them one requires to stand quite still on the first appearance of the mother. I have myself

\section{What \\ Audubon Said} several times had to regret not taking this precaution. The favorite haunts of the Towhee Buntings are dry barren tracts, but not, as others have said, low and swampy grounds, at least during the season of incubation. In the Barrens of Kentucky they are found in the greatest abundance.

"Their migrations are performed by day, from bush to bush, and they seem to be much at a loss when a large extent of forest is to be traversed by them. They perform these journeys almost singly. The females set out before the males in autumn, and the males before the females in spring, the latter not appearing in the Middle Districts until the end of April, a fortnight after the males have arrived. Many of them pass the confines of the United States in their migrations southward and northward. They generally rest on the ground at night, when many are caught by weasels and other small quadrupeds."

Besides the common Towhee there are about fifteen other kinds of Towhees in North America, all but one western, as, the Oregon Towhee, Cañon Towhee, and Green-tailed Towhee. The one which most closely resembles that of the Eastern States is the White-eyed Towhee, found in summer from the coastal country of North Carolina southward through Florida.

\section{Classification and Distribution}

The Towhee belongs to the Order Passeres, Family Fringillida, and Genus Pipilo. Its scientific name is Pipilo erythropthalmus erythropthalmus. It is distributed in summer throughout the United States and southeastern Canada, and winters in the Southern States. The White-eyed Towhee is a subspecies (P.e. alleni) of the South Atlantic Coast and Florida.

This and other Educational Leaflets are for sale, at 5 cents each, by the National Association of Audubon Societies, 1974 Broadway, New York City. Lists given on request. 


\section{THE CHIPPING SPARROW}

By T. GILBERT PEARSON

\section{The National Association of Audubon Socibtibs}

Educational Leaflet No. 80

In the United States about forty kinds of useful, interesting, and native birds are called Sparrows. The one known to more persons than any other is the little confiding Chipping Sparrow. It is the bird that more than any other, perhaps, shows its absolute trust in mankind. It seems not to care for the deep forest, the windy beaches, the vast marshes, or the impenetrable swamps where so many of the feathered denizens of the land are wont to live.

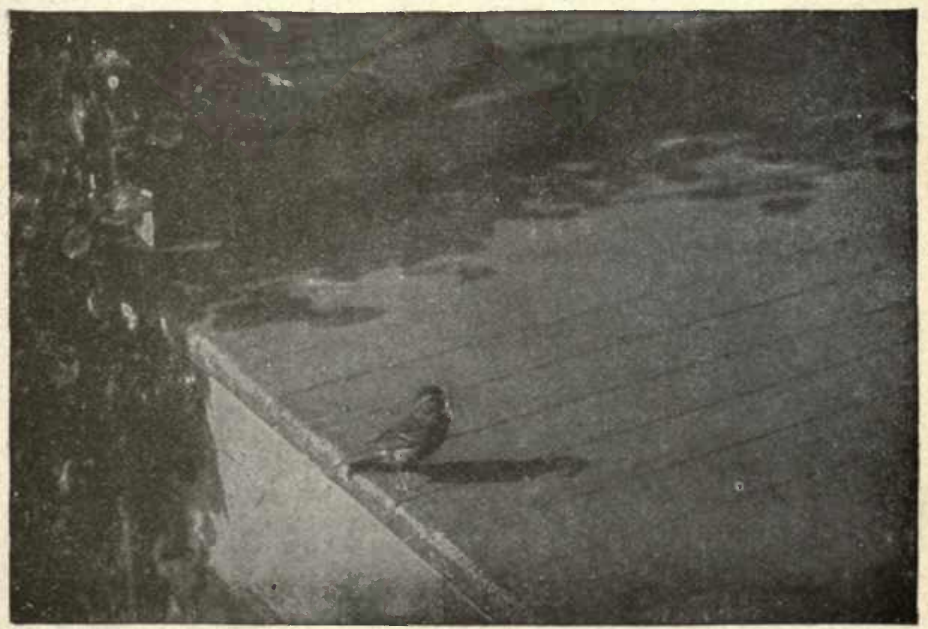

THE SPARROW WHOSE HOME WAS IN THE CLEMATIS.VINB

Photographed by Joseph W. Lippincott, Bethayres, Pa.

If you look for the Chipping Sparrow, particularly in spring, go to the garden, for you can find it there, hopping along the rows of sprouting vegetables. It does not injure any of these tender plants-in fact you may consider yourself fortunate if one or more pairs make their home in your garden.

You will find it in the apple-orchard, by the roadside, and on the lawn. It will fly up in front of you as you pass along the gravel walk, and will alight on the veranda-railing and look inquiringly at you as you emerge 
from the door. It is an unobtrusive bird, and really has no human enemies, so far as I am aware. One may love or may ignore the Chipping Sparrow, but where is the person who dislikes this friendly bird? It does not get in the way; it does not fill roof-gutters with dry leaves and trash; and its simple, chipping notes are so low that they would never awaken one of a morning. It is no wonder that it has been called the "Social" Sparrow.

I have always liked the Chipping Sparrow, it is so like a good woman I once knew, who, though very plain and somewhat unimaginative, was nevertheless considerate, thoughtful, and very gentle. Many persons did not notice her, but those who did always spoke kindly of her.

This is one of the birds that has greatly increased since white men settled the country, for the cultivation of fields and

On the Increase gardens has furnished it just the proper amount of protection, and an abundance of the right kind of food. The trees and bushes that men plant in their orchards and on their lawns provide splendid places for the Chipping Sparrow to build its nest.

The cradle for the babies is a very dainty structure. It is made of dry grasses, with a few small twigs to strengthen and support it. In the center of this one will find a smooth cup lined deeply with horsehair, where four or five pale blue or greenish eggs are laid. Scattered about over the surface of the shell, but particularly numerous around the larger end, is a sprinkling of black or brownish spots. A variety of situations is chosen, so that we may find a nest near the end of a swaying bough or saddled among the twigs of a lower branch of a shade-tree by the street. Often, the birds choose cedar-bushes or other thick shrubs. and in such cases the nest may be only three or four feet from the ground.

I recall one pair that built their home in a clematis-vine, which grew on the veranda-trellis. Here, day by day, we used to watch the parentbirds bring food to their little ones, and it is astonishing how much labor it requires to keep four baby Chipping Sparrows supplied with all the food they will eat. Every two or three minutes one of the parents would flit into the clematis-vine with food for the young.

In the

Clematis-Vine So far as we could tell, it appeared that the male attended to the duties of caring for the young fully as much as did his mate. This, truly, is the correct way to do; but not all father-birds follow this custom.

One of the little Chipping Sparrows seemed to be stronger than the others, and usually raised his head a little higher than his brothers and sisters, and opened his mouth a little wider in an attempt to get all the good things which his parents brought to eat. I fear much of the time he received more than his share. When a little later, however, the young had left the nest, and were learning to fly, this selfish youngster received no more than the others-in fact, on more than one occasion we saw the mother pass him by to give food to a brother or sister that sat farther along on the same limb. 


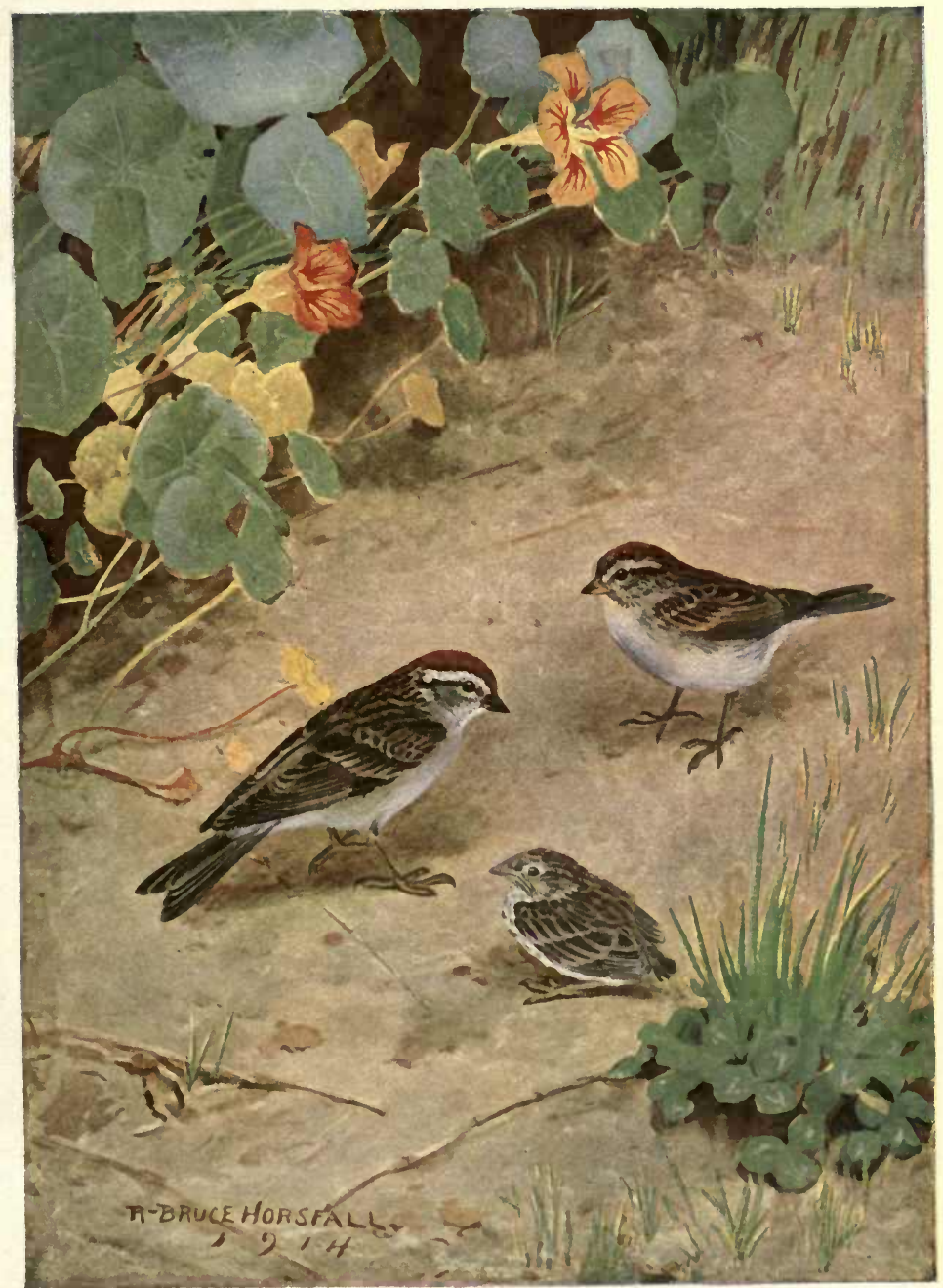

CHIPPING SPARROW

Order-PASSERES

Genus-Spizella
Family-FRINOILLIDA

Species-PAsserina 

It would be pleasant to say that all four of these young Chipping Sparrows grew up and lived happy ever after, but this, alas, would not be telling the truth. Our neighbor had a cat, and the cat knew of the nest in the clematis-vine, and no doubt would have torn it down some dark night had we not arranged some boards and a piece of tin in such a way that it could not climb up the vine. But as soon as the young scattered about the lawn, and before they were able to fly more than a few yards at a time, the cat was ready for them, and before noon of the day they left the nest one of the baby birds had disappeared. It was just after luncheon when I heard the angry chipping of our friends, the sparrows, and, dashing

Beware the Cat? out on the veranda, I saw the cat marching away with a bird-child in its mouth. That cat was well fed and well cared for, and had all the good food that any reasonable cat could mew for, yet its love for hunting was so strong, that, like almost every other cat that you or I have ever seen, it would catch birds if it had the chance.

Chipping Sparrows are very useful birds, for they destroy "worms" (the caterpillars, or larvæ, of moths and butterflies) which eat holes in the vegetables in the garden, and consume grass-blades and the leaves of trees.

Over large areas of the New England States, the gipsy-moth has become a great scourge, for its caterpillars attack nearly all the trees in the country except pines and cedars. They destroy the leaves; and, as trees really breathe through their leaves, the gipsy-moth of course is responsible for

Foe of the Gipsy-Moth killing the trees. Some States have tried many experiments in order to learn how they may rid themselves of these pests.

To learn more about the life-history of the gipsy-moth, the men in charge of the experiments in Massachusetts not long ago built a large inclosure out-of-doors. This was covered and surrounded by a thin netting, inside of which a great many gipsy-moths were placed, where their various habits could be closely watched. Then a curious thing happened: the Chipping Sparrows began to arrive, and would continually break through the frail netting to get inside the frame where they could catch the moths. The men in charge did not think a moment of killing the sparrows. No, indeed! So useful a bird should not be destroyed! They did a much wiser thing, for they kept a man on guard to frighten the sparrows away' when they came too close to the netting. The actions of the birds plainly showed that they much preferred to eat this noxious insect, in-

\section{A Good Testimony} stead of contenting themselves with other kinds of food that might be found in the neighborhood.

These birds are very fond also of beet-worms, currant-worms, and caterpillars of many kinds. Edward H. Forbush, who has spent a great deal of time in finding out especially what birds eat, says: "In all, thirtyeight per cent. of the food of the Chipping Sparrow consists of animal 
matter, three-fourths of which is made up of noxious insects. In June, ninety-three per cent. of the food consists of insects, of which thirty-six per cent. is grasshoppers; caterpillars, twenty-five per cent.; and leafeating beetles, six per cent. I have been much impressed with the value of this bird in the garden during the spring and summer months. It destroys at least three species of caterpillar on the cabbage. It is the most destructive of all birds to the injurious pea-louse, which caused a loss of three

\section{Helping the} Gardener million dollars to the pea-crop of a single State in one year. It is a persistent destroyer of the grubs that mine the leaves of beets. I watched one bird secure eleven of these grubs in a few minutes."

The song of the Chipping Sparrow is little more than a continued, monotonous repetition of chippy chippy chippy. This is given in a high, wiry voice, and the notes are run together until the sound suggests the trilling of some insect. Few sparrows have ever attained a high place as singing-birds.

Late in the summer, Chippy changes his dress. He loses the ruddy brown cap which he has worn all summer, and in appearance now much resembles his mate. He then goes to the fields, where you may find hin associating with Snowbirds, and with other kinds of sparrows. As insectfood becomes scarce, and cold weather approaches, he changes his dict also, and begins to eat seeds of grasses and weeds. Then there comes a morning when Chippies cannot be found; over large arcas of the nortlern part of their range they have disappcared. During

Migration the night they have taken up their long flight toward the south. The journey does not go on continuously, but the birds stop to feed and associate with their friencls here and there on the way.

In the Southern States you may find this bird in winter enjoying the company of friends and neighbors; but wherever found, or under whatever conditions you see it, the Chipping Sparrow shows a gentleness in disposition whicl insures for it the friendship of all who study its ways and spy upon its coming and going.

\section{Classification and Distribution}

The Chipping Sparrow belongs to the Order Passeres, Family Fringillid $\epsilon_{\text {, and }}$ Genus Spizella. Its scientific name is Spizella passerina. It inhabits in summer all North America, from central Canada to Georgia and Texas, and winters in the Southern States. Those on the Pacific slope differ somewhat in color, and are distinguished as a western subspecies ( $S$. p. arizona). 


\section{THE KINGBIRD}

By T. GILBERT PEARSON

The National Association of Audubon Societies Educational Leaflet No. 81

As I made my way one spring morning among the clump of reeds along the margin of a southern lake, keeping a sharp lookout for the deadly water-moccasin snakes, I was startled by an unusual sound. It seemed to come from overhead, and just a little behind me. Turning, I beheld a Hawk darting sharply downward, and only a few feet in front of it a little Spotted Sandpiper was fleeing for its life. By the smallest fraction of a second the Sandpiper avoided the murderous clutch of its enemy, and then dashed into a thin growth of grass. The Hawk veered

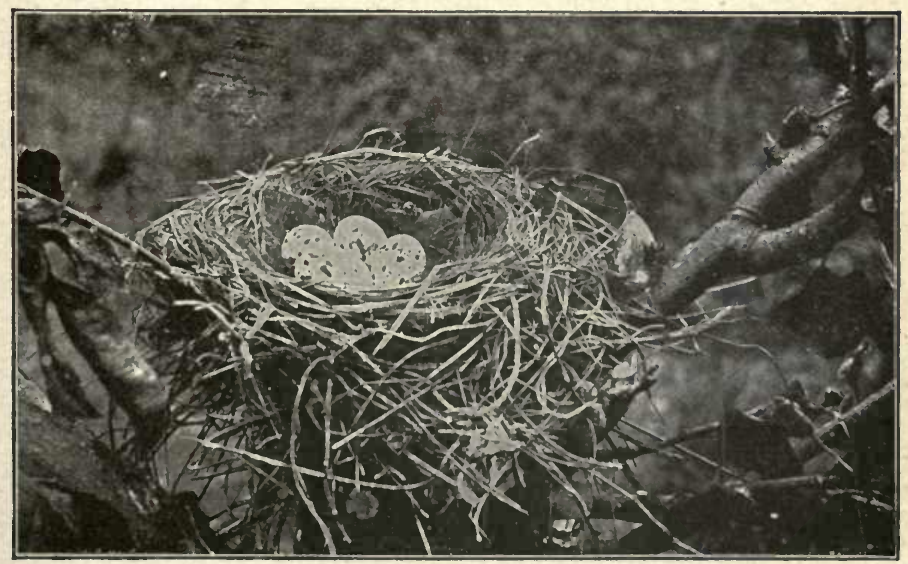

\section{A KINGBIRD'S NEST AND EGGS}

From a Photograph by A. D. Whedon

sharply upward, wheeled around, paused an instant on outstretched wings, and then, catching sight of its prey, was in the act of plunging again, when, like a bolt from a clear sky, something struck it in the back. This something proved to be a small black-and-white bird, which, with sharp, clattering notes and snapping bill, struck continually at the great hawk many times its size.

The hawk at once forgot how hungry it was, and lost sight of the panting, frightened sandpiper, which lay almost helpless on the ground 
below; for all at once another idea had taken possession of its mind, and that was to escape this infuriated bundle of feathers with a sharp beak that was snapping at its back. So it departed across the shallow lake as fast as its big wings could carry it, and its pursuer, a little Kingbird, urged it on with every stroke. The hunter had suddenly found itself the hunted one, and, judging by the haste it used and

The Hunter Hunted the way it dodged, one would think it was as badly frightened as the poor sandpiper had been a few minutes before. For fully a quarter of a mile the Kingbird kept up the chase, ceasing the pursuit only when the hawk had entered the woods.

The Kingbird was the sentry and also the fighting warrior for all that arm of the lake, and woe to any large bird that came near. Later, I saw him several times, and he was ever on the alert. Once he drove off a great Turkey Vulture, actually alighting on its back where evidently he held on to a feather with his bill. Twice I saw him make life miserable for Crows that ventured into his kingdom.

I found his nest, too, and this was a discovery worth while. A button-wood bush had grown up from the mud and among the water-plants, perhaps two hundred feet out from the lake-shore. It was a thin, discouraged-looking bush, but it served well for a Kingbird's nest. In this, three feet above the water, the rather bulky cradle had been built. At a little distance it appeared to be only a streaming cluster of long, gray moss, which might have been blown, during some The Nest gale, from a bare branch of one of the scattered pinetrees back on the shore. When one came near, however, and looked inside, another sight was presented. There, in a cupshaped inclosure, lay as pretty a set of eggs as one might wish to see. They were about an inch long, and perhaps three-fourths of an inch wide; and scattered about over the white surface of the shells were many spots of brown in various shades. The nest was lined with little roots and grass, and the whole structure was compact and strong.

Kingbirds often show a preference for living near streams or lakes, but very offen are found far away from such places. This is true, particularly, in the Northern States, where we may meet with them in old appleorchards, along highways, or in the neighborhood of farm-fences, beside which trees have sprung up and been allowed to grow.

Early one morning, last June, I was out watching for birds just after sunrise. A little girl, with sharper eyes than mine, was my companion. The air was ringing with the song of a Veery, and a

\section{Nest-Building} pair of Red-eyed Vireos were calling repeatedly from the near-by trees. My fellow-watcher was pointing out a Downy Woodpecker she had discovered, when she caught sight of a Kingbird, the first she had ever seen. It was flying slowly and somewhat laboriously, for in its bill it carried a strip of cloth several inches long. A moment later, the bird settled among the twigs and leaves growing on the horizontal limb of a scraggy, gnarled oak-tree just before us. Here it 


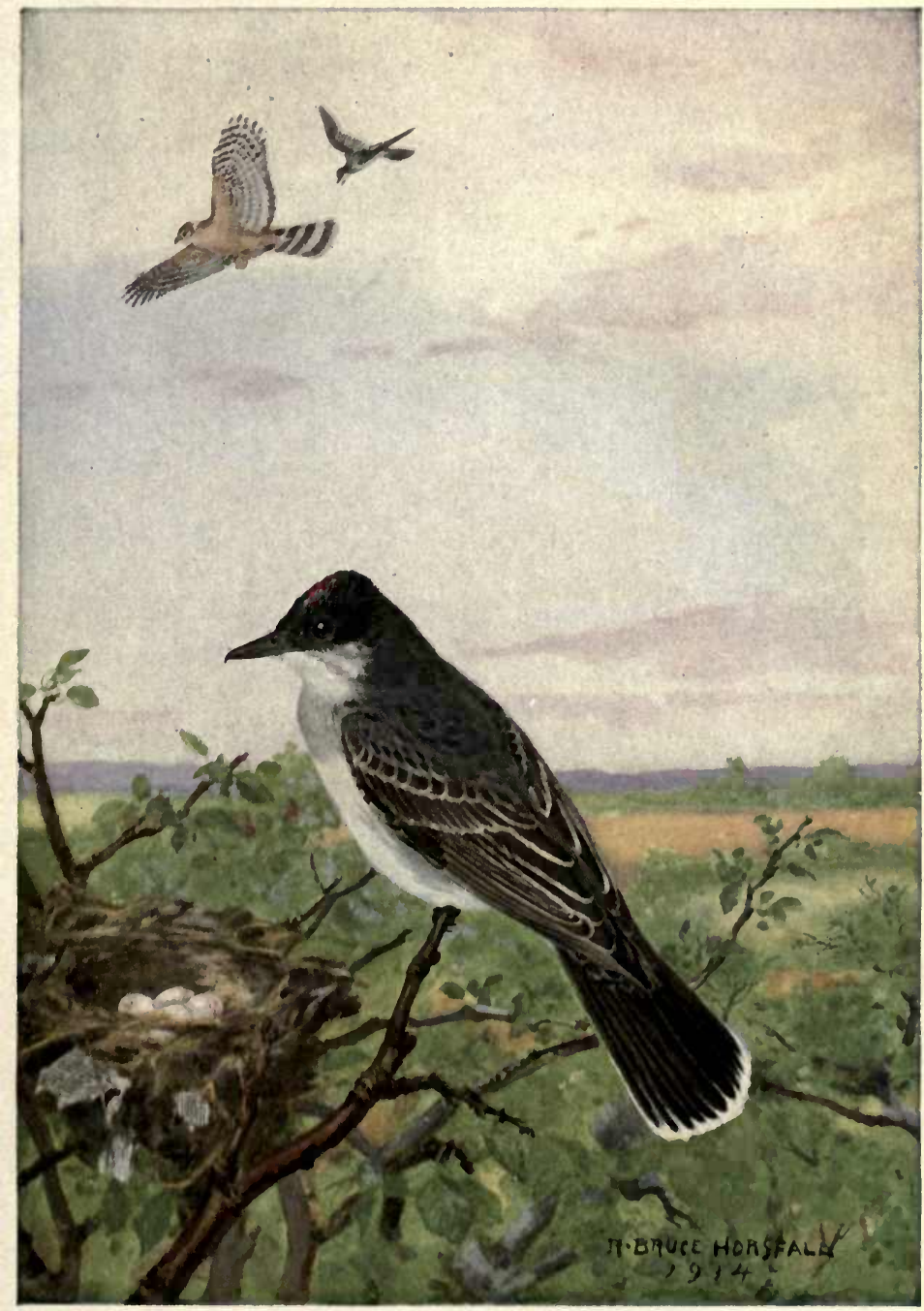

KINGBIRD

Order-PASBERES

Gonus-TYRANNUS
Family-TYranNide

SPOCIOS-TYRAN NUS

National Association of Audubon Societles 


$$
3
$$


remained for two or three minutes, pulling and tugging at the rag. After getting it placed to its satisfaction, it flew away. We had discovered a Kingbird in the act of building its nest, and, so far as we could observe, had actually seen it bring the very first piece of material with which to make it.

Day after day, in the early morning, we would slip out to see how the work was progressing. The birds seemed to work at their nest-building, chiefly, in the early morning; still, it must be confessed we did not watch very closely at other times of the day, and the birds may have continued their efforts at various periods until the sun went down. In making the nest, the birds used old weedstalks, grass, pieces of paper, and rootlets; and it took

Constructing a Home them many days to complete the task. Although it would have been easy to climb up to the nest, we did not do so. The little girl, who belongs to a Junior Audubon Society, told me it was a rather bad practice for children to peep into every nest they found, so we never learned how many eggs were laid in it.

Later, however, we saw three young sitting on the limbs near the nest, where both the father and the mother often fed them. The tree stood not more than twenty feet from the veranda of a summer club-house, where many came three times a day for their meals. Children and dogs romped about the place or sat on the bench under the tree, but the Kingbirds never seemed frightened.

If birds are undisturbed by their human neighbors they soon learn that no one means to harm them, and often become very tame. We all have seen many photographs of Chickadees, Bluebirds, and other small birds, that have become so tame that they would alight on the shoulders or hat of a man or woman who was kind to them.

Hidden by the dark feathers on the top of its head is a bright orangered spot. The Kingbird can open the feathers of its crown whenever it wishes to, in such a way as to show this bright spot. It has been thought by some people that the Kingbird does this to deceive insects into thinking that they have discovered a flower where honey may be gathered. If true, this would be

The Kingbird's Crown very nice for the Kingbird, and no doubt would help it very much in getting a living. Perhaps some member of a Junior Audubon Class, by watching one of these birds, will discover whether or not this supposition is true.

If one watches the Kingbird very long, he will notice that most of its time seems to be occupied with hunting food. Birds have different ways of getting the necessary things to eat. Thus, some wild Ducks dabble in the mud; Woodpeckers find food by searching crevices in the bark and wood of a tree; Kingfishers dart into the waters of lakes and rivers to capture small fish; and Herons wade in shallow water and spear prey with their long bills. The Kingbird uses none of these methods. Standing on the topmost branch of some small tree, telegraph-pole, or barbed-wire 
fence, it will remain motionless, except for frequently turning its head as it searches the air for passing insects. Suddenly it will dash out, sometimes a hundred feet or more, seize an insect, and then return to its perch.

It is always well for us to know what our bird-friends eat. Kingbirds eat flies of many kinds. They also eat mosquitos, and, in fact, there is

\section{Kingbirds and} Bees hardly an insect so unfortunate as to come within their reach that is not destroyed, for the sharp eye of the Kingbird is ever on the watch, and its strong bill seems never to tire of its work. I once knew a man who paid his boy two cents for every Kingbird he shot. This man raised bees, and he was perfectly sure that he often saw Kingbirds-which he, like many others, called Bee Martins-catch bees, as they came across the garden to or from the beehives. So the boy shot the four Kingbirds that lived near his father's place, and then went around the neighborhood hunting for more Kingbirds, killing some as far as four miles from his home. One day, however, a naturalist connected with the United States Department of Agricultura in Washington made a careful study of the feeding-habits of the Kingbird. He found that, in truth, it did eat bees, but that it appeared to eat only the drones!

We all know, of course, that there are two kinds of bees in a hive: one, the workers that gather the honey and take care of the young, and the other the drones who will not gather honey, will not hunt for pollen, and do not, in fact, assume any of the duties around the hive. Perhaps the reason it does not disturb the workers is that they have a sharp sting, while the drones have none.

All day and all night during the warm months of the year, many thousands of insects of various kinds are flying about Sharp Eyes through the air. We do not notice them, but the Kingbird has a much sharper eye than man, and it has been proved that it can see a hundred feet away an insect that we would have difficulty in seeing at a distance of fifteen or twenty feet. After a heavy rain-storm, very few insects are in the air,- the wind and rain having killed many of them. So the hungry Kingbird, from its post, looks around in vain for something to eat. At such times, you will find it on the ground searching for flies and small beetles that have fallen before the force of the wind and rain.

\section{Classification and Distribution}

The Kingbird belongs to the Order Passeres and Family Tyrannide (Tyrant Flycatchers); its scientific name is Tyrannus tyrannus. The species is found in summer and breeds throughout the whole United States and southern Canada, and winters in Central America and southward to northern Brazil.

This and other Educational Leaflets are for sale, at 5 rents each, by the National Association of Audubon Societies, 1974 Broadway, New York City. Lists given on request. 


\title{
THE BALD EAGLE
}

\author{
By T. GILBERT PEARSON
}

\section{The National Association of Audubon Societies}

Educational Leaflet No. 82

It is a real event to see a Bald Eagle wild in its native haunts. It is so large, so majestic, and flies with an evidence of so enormous strength, that one is impressed with the thought that here is the King of Birds.

On one occasion, while eating my lunch

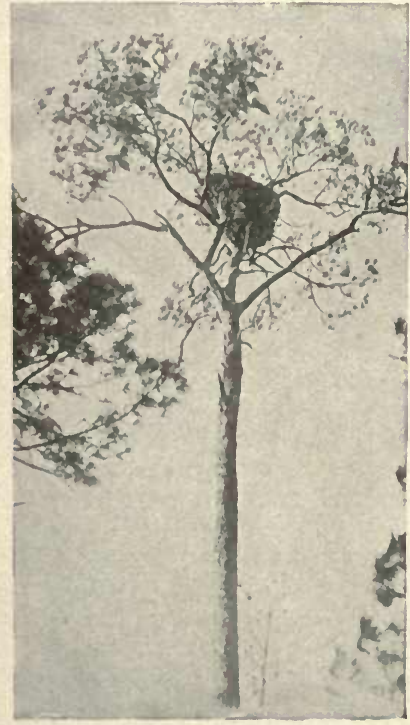

NEST OF BALD EAGLE in the shade of a little bush on a southern prairie, I saw one carry off a lamb. The noise of some running sheep, not far away, caused me to look up just as the eagle rose from the ground with its. prey. It did not once pause and flutter its wings, as birds-of-prey sometines do, in order to get a better hold of its burden, for it seemed to have seized the lamb securely when it first made its downward plunge. The bird flew with truly surprising swiftness, and bore the weight of its "kill" without apparent effort. I watched it for half a mile or more until it disappeared in the forest, and not once did it show any indication of weariness. Years later I read an account written by a birdstudent who watched an eagle alight on the beach after having carried a lamb weighing more than the bird itself for a distance of five miles across a body of water. It is hard to believe that a bird may be strong enough to accomplish such a task as that.

Bald Eagles catch many of the larger water-birds, especially wounded ducks. On the lakes and sounds where much hunting is carried on in winter many hundreds of crippled wildfowl are left behind when the flocks nigrate northward in spring. These fall an easy prey to the eagles that usually frequent such regions. Once I saw one capture a broken-winged Coot in Currituck Sound, North Carolina. At the approach of its big enemy the Coot dived, but soon had to come up to breathe, when the eagle instantly swooped. Again and again the helpless bird dived and 
swam under water, but the eagle was ever on the watch, and in the end they went away through the air together.

That the most expert of diving birds cannot always escape was suggested by my finding a Pied-billed Grebe in a Bald Eagle's nest on one occasion; but it is just possible that the grebe had been picked up dead, for eagles are not averse to eating carrion.

Thus I once found two of them feeding on the carcass of a dead horse in company with a flock of vultures, and on another occasion discovered four Bald Eagles eating some dead rays that fishermen

\section{Habits of a} Vulture had left on the beach. The old story that they sometimes carry off children must be dismissed with the statement that it is highly improbable-for one reason, because babies small enough to be carried by an eagle are not usually left unguarded in situations likely to be visited by these birds. I have never known them to attack domestic animals other than lambs, but C. J. Maynard says:

While encamped on a small island in the Gulf of Mexico, near the mouth of the Suwannee River, I heard one morning a loud squealing among the half-wild hogs, of which there were an abundance in the place. I found that three eagles were attacking the newly born progeny of an old hog, and she was endeavoring to defend thein. The little grunters, of which there were several, had taken refuge under the top of a fallen tree, which, however, afforded them only partial protection; thus the eagles could see them, and, tempted by the dainty titbits, would swoop downward and endeavor to grasp the little black-and-white pigs in their talons, but were constantly repulsed by the anxious mother, who bravely defended her offspring, at the same time giving vent to some of the most ear-splitting squeals that ever a distressed hog uttered. I do not know how the strife would have ended, had I not interfered.

Bald Eagles probably like fish better than any other food, for they seem always to be more abundant where the supply of fish is large. A dead fish is of course easy to secure, but many times I have seen them fly down and capture living ones. At least three-fourths of such attempts were fruitless, for this eagle does not seem to possess the same

The Unlucky Osprey skill in this direction that is enjoyed by its somewhat more agile neighbor, the Osprey. The eagle is very shrewd, however, and, having no inconvenient scruples whatever as to the methods that may be employed in getting food, it does not hesitate in the least to take the Osprey's prey away from it.

One of the most thrilling sights of the wilderness is to witness such an occurrence. An Osprey laden with its fish cannot possibly out-fly a healthy Bald Eagle, although when pursued it certainly does its best to escape. No matter how hard it tries to get away, the result is usually the same. The eagle gives hot chase, and, soon rising above the Fish Hawk, strikes downward at the smaller bird, which has been rising higher ever since it has discovered that it is being followed. Usually one stroke by the eagle is enough, but sometimes half a dozen are necessary before the 


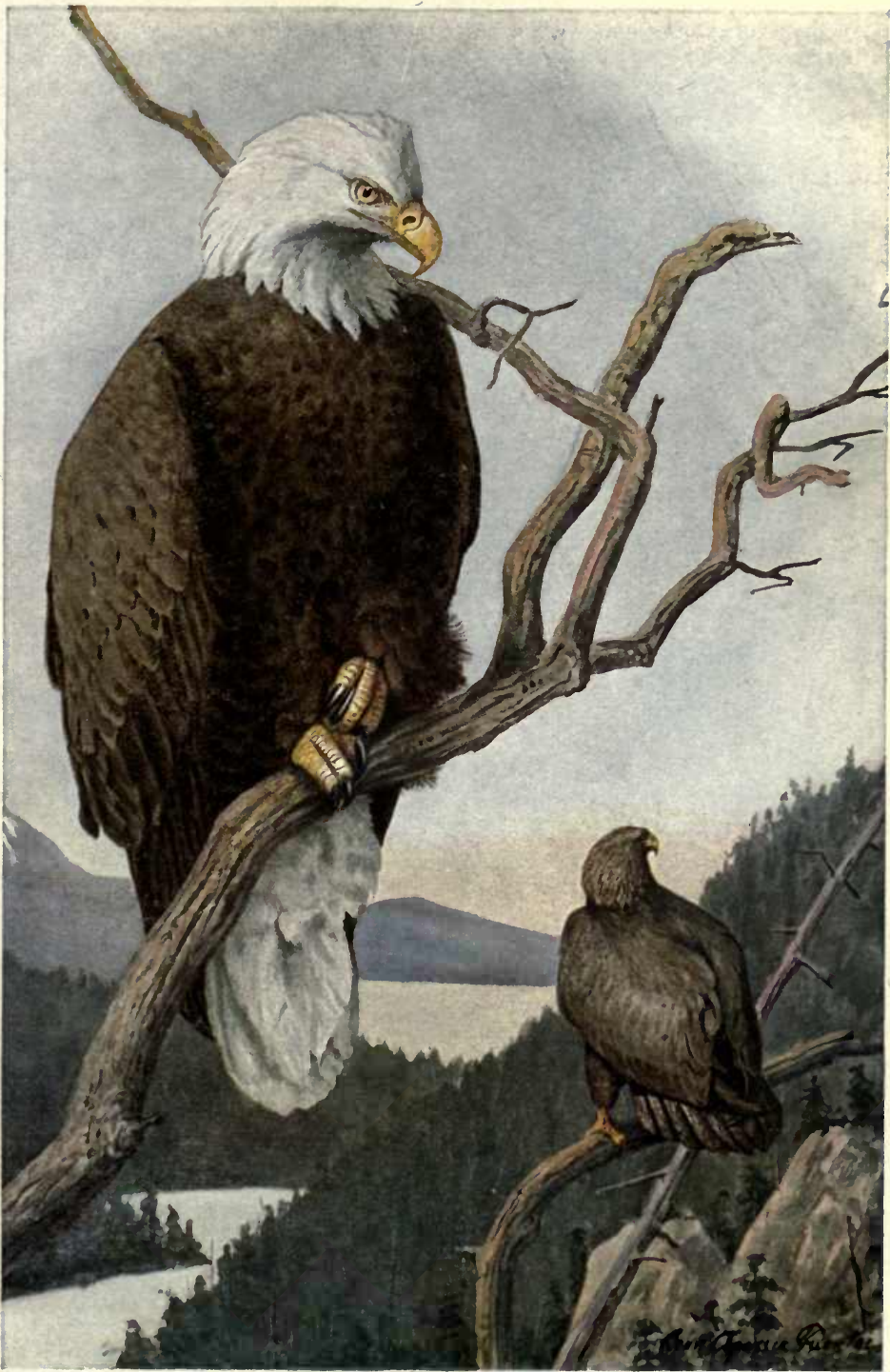

Order-RAptoRES

Genus-Halie ETUS

Family-Butronide

Species-laucocephalus

National Assoclation of Audubon Socleties 

Osprey in despair drops its fish. Instantly the eagle darts downward with half-closed wings at an enormous speed, and catches the fish in mid-air before the tree-tops are reached.

In mountainous regions or along rocky sea-coasts Bald Eagles sometimes build their nests on cliffs, but their eyries are usually found in tall trees. The first nest to which I ever climbed, many years ago, was in a southern forest near a lake-shore. The tree was a large one, and the only

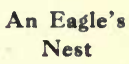

possible way to make the ascent was by nailing cleats of wood to the tree as I progressed, keeping myself safe in the meantime by a rope passing around the trees and over one shoulder and under the other arm. The strips of wood were pulled up by a cord from the ground as needed. By actual measurement, the first limb on this giant pine was $8 \mathrm{r}$ feet from the ground, and the edge of the nest was I3I feet in the air.

It is one thing to climb to a Bald Eagle's nest, and quite another to look into it when you get there. Above my head was a great accumulation of fragments of limbs and twigs, which made a mass fully five feet across and nearly as high. This great structure was supported by three limbs which represented the main fork of the tree. It was only by tearing away several armfuls of this material, which, however, in no way damaged the usefulness of the nest, that I was able to climb one of the limbs to a position where I could see into the eyrie. This nest was almost flat, with a shallow, basin-like depression in the center, where lay two eaglets covered with a whitish down. They offered no resistance to my handling, and the only complaint uttered was a low, whistling cry.

The ascent of this tree was made on the twentieth of January, and, as eagles sit on their eggs for about a month, the presence of the eaglets showed that the eggs must have been laid some time in December.

The next year I again climbed this huge forest-monarch, and, as before, the old eagles circled around at a sufficient distance to render them safe from gun-fire had I entertained any designs on their lives. This second visit was on January I4, and this time I found the nest contained young birds, the expanse of whose wings measured three and a half feet from tip to tip. The eggs from which they came must have been laid before Thanksgiving Day. This was in Florida, in many parts of which Bald Eagles are abundant. Farther north, the eggs are deposited later in the year, and in Alaska they are not laid until April.

Usually the nests are plaçed well back in swamps, or along unfrequented stretches of lake-shore or coast-line. They are ordinarily near water; in fact, all of the tiventy or more nests that I have found were so situated that, while brooding the eggs, the old eagles could look out over some body of water.

If the birds are nat killed, the same eyrie is often occupied for a great many years in succession, and is repaired each season by the addition of a new layer of sticks, twigs, pine-needles, and sometimes of moss. This additional material varies from two to four inches in thickness, and. as the 
season goes on, there is added to this an accumulation of bones from the fishes, birds, and other animals brought to feed the young. Thus year by year the structure grows, until sometimes it becomes immense. I recall seeing one in eastern North Carolina that must have been over seven feet in thickness from top to bottom.

Many birds receive names of a more or less descriptive character, as Red-headed Woodpecker, Crossbill, and so forth. It is erroneous, how-

\section{Poorly}

Named ever, to regard the Bald Eagle as a bald-headed bird, for its crown is well covered. When three years old, it passes.through a molting-period, which results in the bird's acquiring a white head, neck, and tail. Many Bald Eagles are observed every year that do not possess these white feathers; such birds, of course, are still in their youthful plumage. At a little distance it is often difficult to distinguish the young of this species from a Golden Eagle; the latter is rare, however, in the eastern United States.

In writing of this bird, the great Audubon expresses regret that it should have been selected as the national emblem, and refers to the opinion of Benjamin Franklin, who wrote: "For my part, I wish the Bald Eagle had not been chosen as the representative of our country. $\mathrm{He}$ is a bird of bad moral character, and does not make his living honestly." After speaking of the eagle's habit of constantly robbing the Osprey, Franklin

\section{Franklin's \\ Opinion}

continues: "With all this injustice, he is never a good case, but, like those among men who live by sharping and robbing, he is generally poor. Besides, he is a rank coward, the little Kingbird, not bigger than a sparrow, attacks him boldly, and drives him from the district."

Despite this unlovable part of the Bald Eagle's character, the fact remains that it is one of the most interesting of our wild birds, and it would indeed be a calamity if its race should be exterminated. In regions where the birds become a source of serious loss to the sheep-raisers, we cannot well blame men for occasionally killing these raiders of the sheepfold, but wanton shooting of this fine bird should be strenuously discouraged.

\section{Classification and Distribution}

The Bald Eagle belongs to the Order Raptores, and to the Family Buteonida. Its scientific name is Halicetus leucocephalus. It is resident throughout North America from Mexico to the northern limit of tree-growth; but those in the extreme north are separated as the subspecies $H$. l. alascanus.

This and other Educational Leaflets are for sale, at 5 cents each, by the Naticnal Association of Audubon Societies. 1974 Broadway. New York City. Lists given on request. 


\section{THE SURF SCOTER}

\section{By T. GILBERT PEARSON}

\section{The National Association of Audubon Societies}

Educational Leaflet No. 83

If you chance to be aboard a vessel steaming up the Hudson River late in October you may see, if you keep a sharp lookout, many flocks of wild ducks. If you examine these through a field-glass you will probably discover some that appear larger than others, and that many of them are black. Watch closely for such birds, for these large black ducks of the open waters are pretty sure to be Surf Scoters. They do not remain here long, and after the middle of November are rarely seen on the Hudson River. At this season they also frequent the water of Lake Champlain, and

Winter

Visitors to some extent other lakes and rivers, particularly along the sea-board; they are numerous too at some places on the Great Lakes.

The Scoters come down from the north with the general movement of the feathered hosts that are fleeing before the freezing advance of the Ice King. Being particularly fond of open water, few, indeed, are the individuals that care to linger in lakes and rivers which may freeze. Hence if we want to find the Surf Scoter in winter we must journey down by the sea. Out in the rolling Atlantic, off Long Island, they are usually numerous at this season, and also may be met with along the New England coast, where they begin to arrive early in September. They occur along the coast southward as far as South Carolina, and some have been known to wander to Florida. In the Pacific Ocean, off Washington and Oregon, they are even more abundant than in the Atlantic, and at times go as far south as northern Mexico.

Of the three species of Scoters found in North America it is possible that this is most abundant. E. W. Nelson mentions a flock found by him near Stewart Island, Alaska, which formed a continuous bed of black bodies sitting closely together on the water over an area that averaged more than half a mile in width, and about ten miles in length. This observation was

Huge

Flocks made late in the breeding season, and apparently all the birds were males. When rising from the water the noise from their wings was like the continuous roar of some gigantic cataract. The species must have been very numerous for these were all nales, and we must remember that females and young were doubtless in far greater numbers in the neighborhood.

The summer home of the Surf Scoter is in the far North: none is known to rear its young in the United States. Those occasionally found within our borders in summer are either cripples, as the result of winter shooting, or are non-breeding individuals. They nest in suitable situations north of a line drawn through Laborador, northern Quebec, Great 
Slave Lake, and southern Alaska. Audubon, describing a nest that he found in Labrador, wrote:

"For more than a week after we had anchored in the lovely harbour of Little Macatina, I had been anxiously searching for the nest of this species, but in vain; the millions that sped along the shores had no regard to my wishes. At length I found that a few pairs had remained in the neighborhood, and one morning, while in the company of Captain Emery, searching for the nests of the Red-breasted Merganser, over a vast and treacherous fresh-water marsh, I suddenly started a female Surf Duck from her treasure. We were then about five miles distant from our har-

Audubon's

Experience bour, from which our party had come in two boats, and fully five and a half miles from the waters of the Gulf of St. Lawrence. The marsh was about three miles in length, and so unsafe that more than once we both feared, as we were crossing it, that we might never reach its margin.

"The nest was placed amid the tall leaves of a bunch of grass, and raised fully four inches above its roots. It was entirely composed of withered and rotted weeds, the former being circularly arranged over the latter, producing a well-rounded cavity, six inches in diameter, by two and a half in depth. The borders of this inner cup were lined with the down of the bird, in the same manner as the Eider Duck's nest, and in it lay five eggs, the smallest number I have ever found in any Duck's nest. They were two inches and two-and-a-half eighths in length, by one inch and five-eighths in their greatest breadth; more equally rounded at both ends than usually; the shell perfectly smooth, and of a uniform pale yellowish or cream-color."

In a letter which the writer recently received from W. E. Clyde Todd there occurs this statement:

"The Surf Scoter breeds on Charlton Island, near the head of James Bay, and along the east coast of the same, as far south as the Sheppard Islands, in latitude $52^{\circ} 45^{\prime}$, at both of which localities I encountered young birds in the summer of 1912. On July 12, at Charlton, a brood of four ducklings, not over a week or ten days old, accompanied by their parents, were discovered in a small lake hidden away in the woods, nearly

Nesting in

James Bay two miles from the shore. This raised the question as to whether the old birds are accustomed to seek out such retired situations as nesting-places, and when and how the young are conducted to the open waters of the bay.

"Later in the season (August 3) a female Scoter with her brood was met with in a sheltered cove along the shore of one of the Sheppard Islands. The young at once made for the shore, while she pattered off in an opposite direction, endeavoring to draw attention to herself-just as I have seen other ducks do under similar circumstances."

The male of this duck has a striking appearance, as may be seen from the accompanying drawing. His face can hardly be said to be handsome, however, and yet no less an authority than William Leon Dawson says 


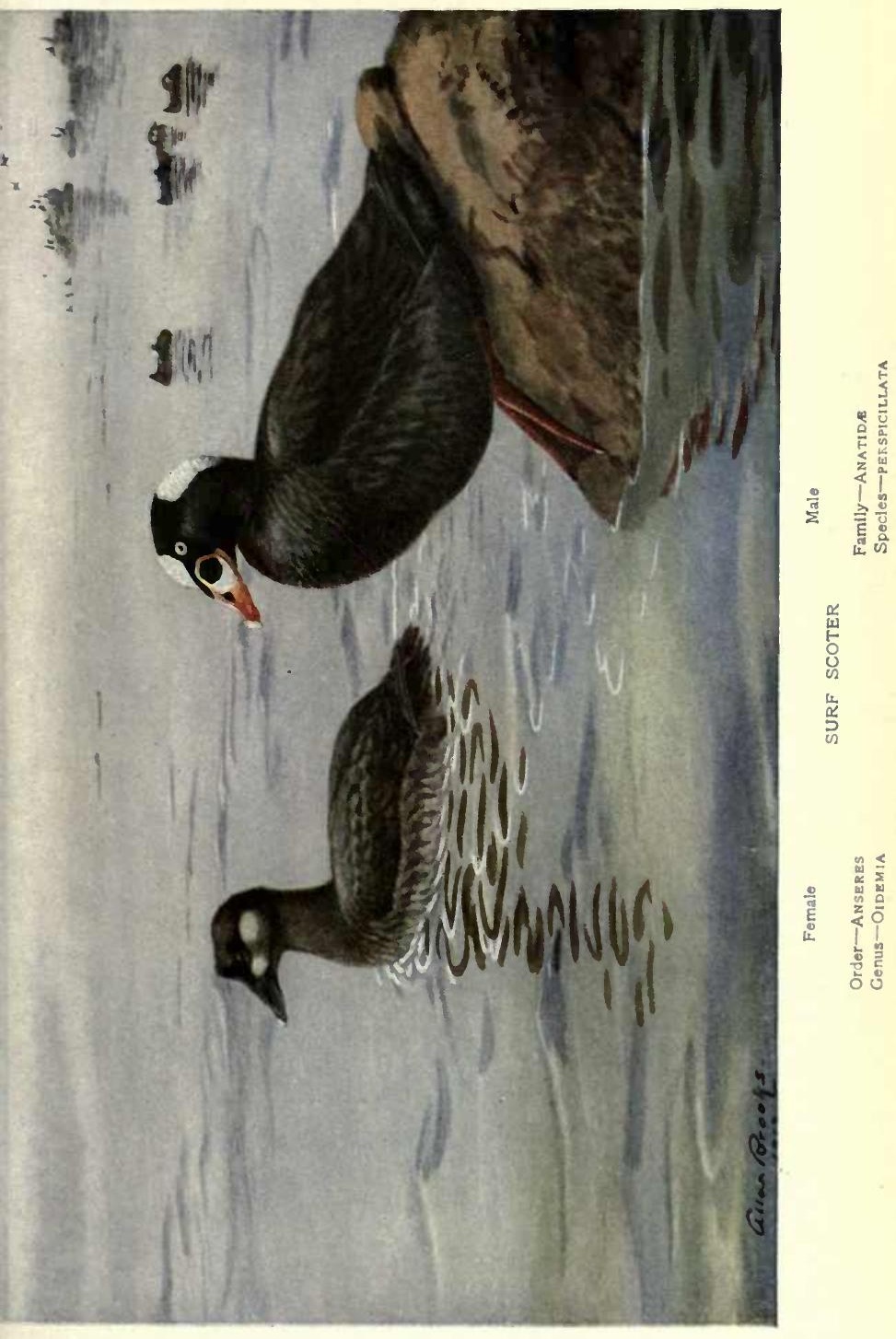



that duck ladies like him. "In fact they have to," he continues, "for they are such homely bodies themselves that the perversity of attraction must be mutual. I have seen a Surf Scoter courtship in mid April. Five males are devoting themselves to one female. They chase each other about viciously, but no harm seems to come of their threats; and they crowd around the female as though to force a decision. She in turn chases them off with lowered head and outstretched neck and great show of displeasure. Now and then one flees in pretended flight and with great commotion, only to settle down at a dozen yards or so and then come sidling back.

\section{Courtship}

"If she will deign a moment's attention, the gallant dips his head and scoots lightly under the surface of the water, showering himself repeatedly with his fluttering wings. One suitor swims about dizzily, half-submerged, while another rises from the water repeatedly, apparently to show the fair one how little assistance he requires from his feet in starting, a challenge some of his corpulent rivals dare not accept, I ween. I have watched them thus for half an hour, off and on."

At many points in the ocean along the New England coast, where other ducks are not always abundant, the Scoters, locally known as Sea Coots, are extensively pursued by gunners. In describing the methods of hunting them in these regions, George Bird Grinnell has written:

"Ducking in line is a communal form of hunting. The gunners of a locality agree all to go out on a certain day, and unless fifteen or twenty boats go it is useless to make the start. The boats range themselves in a line off shore, from some headland or point which separates two bays in which the ducks commonly feed. The first boat is placed two or three hundred yards off the shore, the next one a hundred yards outside of that, the next still further out, until the twenty boats extending out from the point make a cordon of gunners, extending out to seas nearly a mile from the point. Usually lots are drawn for position, those nearest the shore not being so desirable as those farther out. An effort is made to be on the ground before daylight, as the shooting begins with the earliest dawn. Often, therefore, the gunners are obliged to rise at two or three o'clock in the morning to make their way to the shore, get into their boats, and perhaps pull a distance of three or four miles before reaching the ground.

Method of Shooting

"The sky grows brighter and brighter, more gunshots are heard, and presently the sun arises. Now, as one looks seaward, great bunches of birds can be seen rising from the water, and these breaking up into small flocks in all directions. Perhaps the first to approach the line will be a bunch of 'Coots,' some of them white-winged, others dead black, and still others gray. They fly swiftly and steadily, and come nearer and nearer, until they have almost reached the line of boats, and then noticing them-seemingly for the first time-they try to check themselves: but it is too late to turn, and with swift and steady flight, at wonderful speed, they fly on, passing between two of the boats, and twenty or thirty 
feet above the water. In each boat a man springs to his knees, follows the swift course of the birds for an instant with his gun, and fires."

Forbush has declared:

"The 'Coots' mate early, before the spring migration commences; and after they are mated if one be shot the other will follow it down to the water, and if frightened away will come back again. Therefore, the gunner who understands their habits seldom fails to bag both.

This Scoter is an experienced diver and can swim such a long distance under water that it is easy for it to escape the gunner in a sail-boat by

\section{Skill in}

Diving

constantly changing the direction of its flight under water. Some times a cripple, if pursued, will dive to the bottom, and seizing some marine plant with its bill will hold on and commit suicide by drowning rather than submit to capture by its greatest and most persistent enemy."

The food of the Surf Scoter consists chiefly of mussels and other bivalves of various kinds that dwell in the seas, bays, and river-mouths. W. L. McAtee, of the Biological Survey, in Washington, is responsible for the statement that he dissected nine specimens of this bird to ascertain on what they had been feeding. About 80 per cent. of the food which these birds had taken, shortly before being killed, consisted of mussels ; about 14 per cent. of periwinkles; and about $61 / 2$ per cent. of algæ and eelgrass. The flesh of few if any birds whose diet consists of fish or shell-fish is really palatable; and it would seem that this fact alone would protect the Scoter from the onslaught of gunners, to which it is subjected during its southern migration. As it is universally regarded as a legal game-bird it may be interesting to note just to what extent its flesh is esteemed by epicures. Speaking of the Scoter as an article of food. Walter H. Rich in "Feathered Game of the Northeast," says:

"They are unusually tough customers either in life or at the table. Most of our cooks believe it impossible to so prepare this bird as to make

\section{Not Good \\ to Eat}

it decent food for any but a starving man. The best recipe I have seen runs somewhat as follows: First. skin your fowl and let it parboil in saleratus water at least one day, or until it can be dented with a fairly sharp axe. If your courage holds out the game is now ready to stuff and bake as you would any other duck, except that you must put enough onions into its inside to take away all Coot flavor. Arriving at this stage of proceedings there are two lines of retreat yet open to you; either throw your delicate morsel away or give it to someone against whom you hold an ancient grudgeon no account should you try to eat it."

\section{Classification and Distribution}

The Surf Scoter belongs to the Order Anseres, Family Anatida, and Subfamily Anatina. Its scientific name is Oidemia perspicilata. Its summer home is northern Canada and Alaska, and it winters along the Pacific Coast and in the northern United States.

This and other Educational Leaflets are for sale, at 5 cents each, by the National Association of Audubon Societies, 1974 Broadway, New York City. Lists given on request. 


\section{THE SHOVELLER}

\section{By T. GILBERT PEARSON}

\section{The National Association of Audubon Societies Educational Leaflet No. 84}

The most characteristic feature of the Shoveller is its great bill, which measures about two and a half inches long and nearly one and a quarter inches in width. Spoon-bill is the name by which this duck is known to many gunners; other names are Swabble-bill, Shovel-bill, and Cow-frog. Despite its large bill, which seems entirely out of all proportion to the size of the bird, the male Shoveller is a particularly beautiful Duck, and because of its striking green head and reddish belly it is sometimes mistaken for a male Mallard. The female, although she has an equally

\section{Plumage}

large bill, is not adorned with the bright plumage of her mate-in fact, it is a common characteristic among water-fowl that the female wears a more somber plumage than does the drake.

Throughout the eastern and central United States Shovellers are rarely seen in summer. They begin to arrive from the North upon the approach of cold weather, usually among the first Ducks to appear, and frequently are found in company with Teals or Pintails. To see them one should go to such fresh-water or brackish-water marshes as are common along the Atlantic Coast from Maryland southward. In the lower Mississippi Valley Shovellers are very plentiful, and they occur also in large numbers at many places on the Pacific Coast. Some individuals go as far south as Central America.

The student does not progress far in the study of wild-fowl before he discovers that the family Anatida is divided into five sub-families, one of which is known as "River and Pond Ducks." To this group belong the Mallard, Black Duck, Pintail, Gadwall, Widgeon, Shoveller, and our three American Teals. They are grouped together under this title because of their habit of feeding in the shallow backwaters of rivers, ponds,

Two Sorts of Ducks and lakes, and in marshes. The "Bay and Sea Ducks," which constitute another sub-family, are usually found in deep water, and frequently dive many yards for their food.

If you slip up to a Shoveller while he is getting his breakfast, you will find him dabbling in water ustally but a few inches deep. Here he will skim the surface, catching such insects and larva as may happen to be floating by; and from the mud he will collect seeds, and such edible animal-matter as crustaceans and small mollusks. Sometimes the bird will "tip up" while feeding, In this way it can reach down- 
ward several inches, when only the rear end of the body will remain in sight, the tail pointing directly upward. While thus engaged a flock of Spoonbills presents a most ludicrous appearance.

Where suitable vegetable food is to be found, the Shoveller does not pass it by. In many favorite haunts there grows a little tuber known as the wild potato, which is about the size of an onion "set." Cut it open and the substance within the rind will be seen to resemble closely that of a potato. All river and pond Ducks are very fond of this wild food, and if any Shovellers are about they are pretty

\section{Food}

sure to get their share. They are usually silent birds while feeding, but on their breeding-grounds may frequently be heard talking among themselves, their one favorite word being took, many times repeated.

Shovellers feed mostly at night, especially in places where they are much pursued by gunners. I have often seen dozens of flocks come from the marshes at sunrise and fly out to the open water, far from any place where a gunner might hide. There, if the weather is fair and not too windy, they will often remain until the shades of night and the pangs of hunger again call them back to the tempting marshes. They do not gather in enormous flocks, like some other Ducks. I have never seen over forty in one company, and very often they pass by in twos and threes. In hunting them, the fowler usually conceals himself in a bunch of tall grass or rushes, on or near the margin of an open pond; and after anchoring, near by, twenty or thirty wooden duck-dummies called decoys, sits down to wait the coming of the birds. Sometimes the Ducks fly by at a distance of several hundred yards. It is then that the hunter begins to lure them by means of his artificial duck-call. "Quack-quack, quack-quack," comes his invitation from the rushes. The passing birds, unless too intent on their journey to heed the cry, see what they suppose to be a company of Mallards and other Ducks. evi-

\section{Calling to} Decoys dently profiting by a good feeding-place, and, turning, come flying in to settle among the decoys. It is just at this moment, with headway checked and dangling feet, that they present an easy mark for the concealed gunner.

Audubon declared the flesh of the Shoveller to be as good for the table as that of a Canvasback, and other writers have made similar statements. While visiting the Delta Duck Club, near the mouth of the Mississippi River in the autumn of 1915 , I found that the members of the Club did not rate the Shoveller particularly high as a game-bird; and the President of the Club told me that he usually let them go by without firing at them. In other hunting regions, where I have visited and talked with gunners, I found that Shovellers were regarded about as highly as Teals, and were usually shot whenever an opportunity offered.

The bird's body is really not greatly larger than that of the Teal, although its appearance seems to indicate a decidedly heavier bird. 


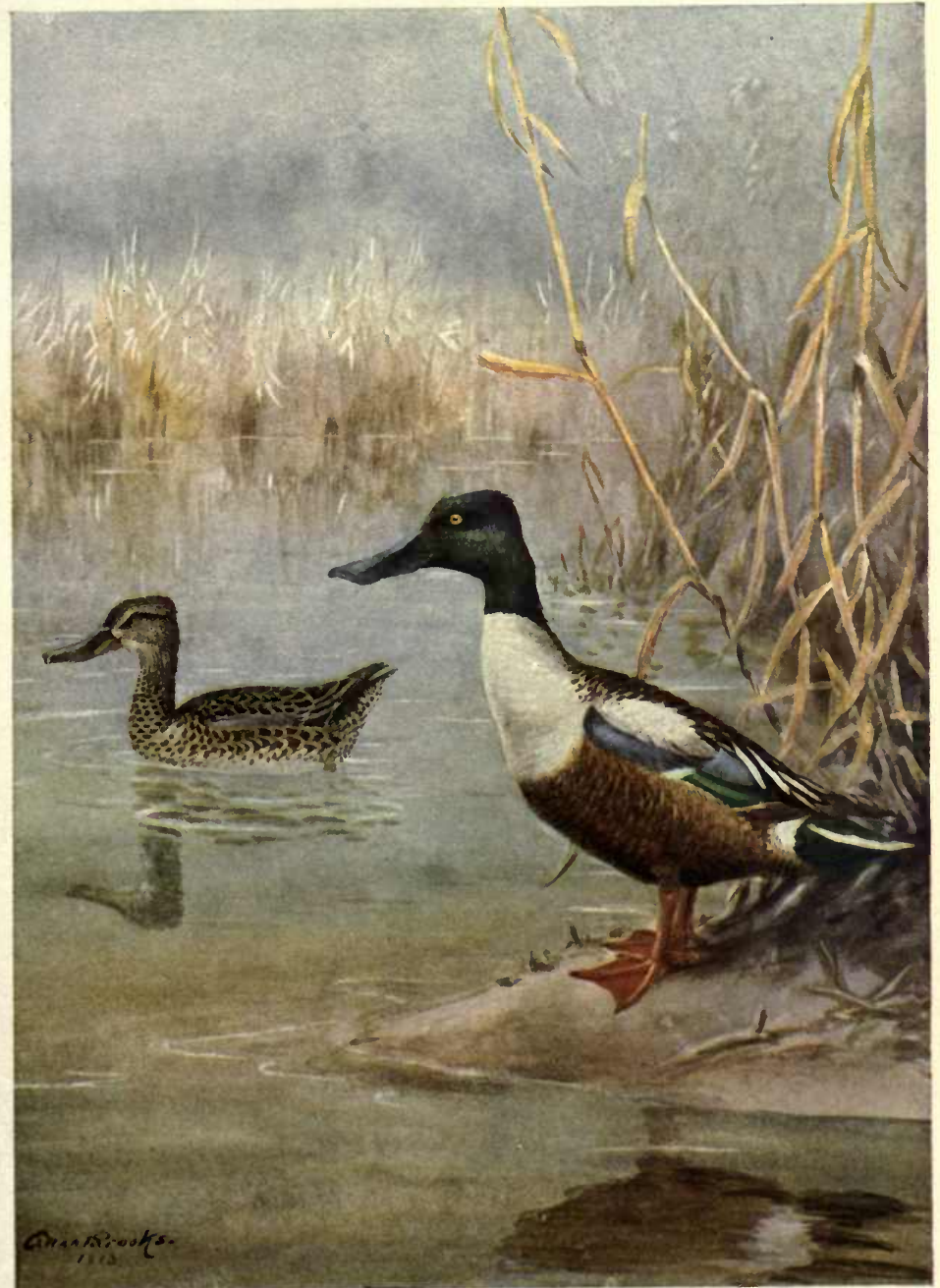

SHOVELLER

Order-ANSBRES

Genus-Spatula
Family-ANaTIDE

Specles-CLYPEATA

National Association of Audubon Societies 

For some unknown reason Shovellers seem never to get fat like other Ducks, and perhaps this is one reason why some hunters do not care much for them. They are very swift flyers, and sometimes travel, doubtless, at the rate of from sixty to eighty miles an hour.

The summer home of the Shoveller tribe is in the vast expanse of territory between Minnesota and Alaska, although some pairs breed as far south as Texas; but they are rarely found nesting in the eastern United States.

In writing of their breeding habits in North Dakota, in The Auk, 1902, Mr. A. C. Bent says:

"They frequent the same localities as the Blue-winged Teal, are equally tame, and probably lay their eggs about the same time as this species. We found only two nests of the Shoveller, in spite of their universal abundance. From the fact that we frequently saw them flying about in pairs, I inferred that many of them do not complete their sets before June 15, which would make this one of the later-laying species.

"After the sets are completed, the males associate with Mallards and Pintails in the smaller ponds and open sloughs. Nearly every slough, meadow, or pond-hole that we visited contained one or more pairs of these handsome little Ducks. The charm of collecting and studying birds in this highly favored region is greatly enhanced by constantly flushing this and the other numerous species of Ducks from every favorable locality. We were kept in a constant state of delightful expectancy, and were seldom disappointed.

"The nesting-ground of the Shoveller is the broad expanse of virgin prairie, often far away from the nearest water, sometimes on high, dry, ground and sometimes in moist meadow-land or near a slough or pond. The first nest that we found was in the center of a hollow in the prairie between two knolls, where the ground was moist but not actually wet, and where the grass grew thick and luxuriantly. The nest was well hidden in the thick, green grass, so that we never should have found it if we had not flushed the bird within ten feet of us.

It was merely a depression in the ground, well lined with dry grasses, and sparingly lined with gray down

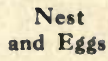
around the eggs; more down would probably have been added as incubation advanced. The ten eggs which it contained were perfectly fresh when collected on June 3."

The Shovellers that in winter inhabit the marshes, ponds, and ricefields of the South Atlantic Coast, reach that region after a long overland journey from their summer-home in the Northwestern States or in Canada. They come to the coast in the neighborhood of Maryland and then turn southward. The eastern flight thus passes southward of the Northeastern States, so that in this part of our country the Shoveller is rarely found. 
Mr. Witmer Stone records only three occurrences in New Jersey since 1888. Eaton says, in his "Birds of New York," that although this species is found in migration in western New York it is seldom seen on any of the great ducking-grounds of Long Island. Mr. William Brewster, in writing of its occurrence in Massachusetts, declares it to be "one of the very rarest of the surface-feeding Ducks."

Before the sale of wildfowl was prohibited in New York, it was not uncommon to find Shovellers in the markets of its cities; but these were birds that were sent in from either the West or the South. In Mexico City, I found them. common in the markets, along with Teals, Mallards, and Pintails. Where it is possible to sell them, they usually bring a fairly good price, although, owing to their small size, they do not command as much as the Canvasback, Redhead, or Mallard. In

Market

Value the winter of I9I5, a gunner offered to sell me a pair on the streets of New Orleans for sixty-five cents. It was against the law in Louisiana to sell or offer for sale these birds, and I am not certain that this man was able to dispose of his Ducks before being taken in charge by a gamewarden.

On the whole the Shoveller is not only one of our handsomest species of wildfowl, but is a very valuable game-bird. The numbers annually killed are prodigious, and it is the eighth wonder of the world that it has been able to withstand the continuous persecution of gunners to which it has been so long subjected. Laws prohibiting the sale of wildfowl have been enacted in a few States within recent years, and birdreservations have been established in regions inhabited by the Shoveller. Where sale is prohibited the chief incentive for killing by the markethunter is taken away, and thus one big destructive agency is removed. The progress made in both of these directions is too slight to insure the perpetuation of the species on our continent, but, as Shovellers are still to be found in goodly numbers, and as the sentiment for birdconservation is rapidly growing, it would appear that this Duck has a fair chance of persisting among us for a long time to come.

\section{Classification and Distribution}

The Shoveller belongs to the Order Anseres, Family Anatida, and Subfamily Anatina, Fresh-water Ducks. Its scientific name is Spatula clypeata. It inhabits all North and Middle America, and breeds in suitable places throughout its range.

This and other Educational Leaflets are for sale, at 5 cents each, by the National Association or Audubon Societies, 1974 Broadway, New York City. Lists given on request. 


\section{The Chestnut-Sided WARBLer}

By T. GILBERT PEARSON

\section{The National Association of Audubon Societies Educational Leaflet No. 85}

Among the most charming birds in the world are the members of that group classified as the family of Wood Warblers, containing about one hundred and fifty-five known species. They are found in no country but America. Seventy-four kinds occur in North America, and fifty-five

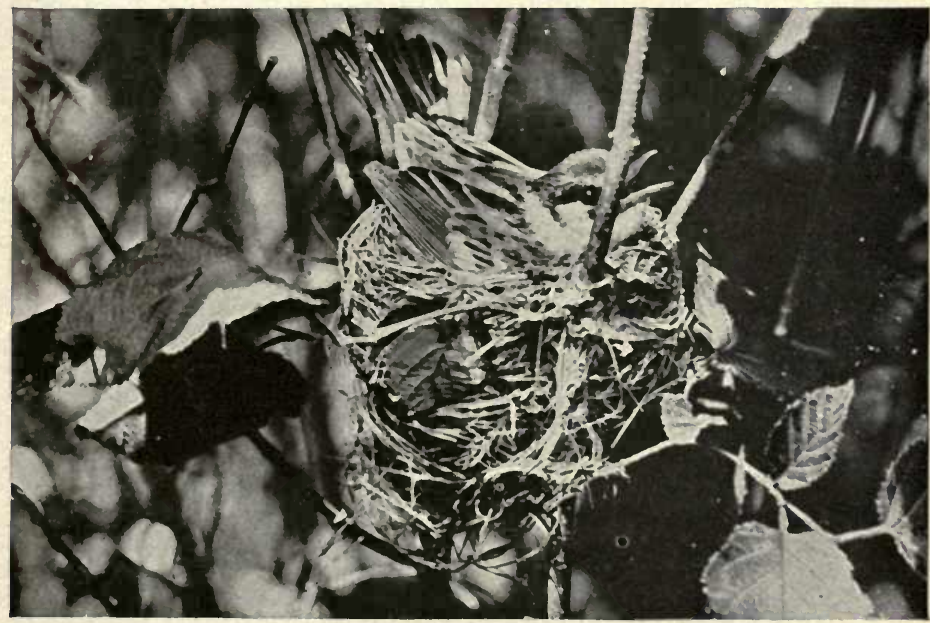

\section{CHESTNUT.SIDED WARBLER ON NEST}

Photographed by Herbert K: Job

of these have been recorded in the United States. They are small birds, measuring as a rule less than five and one-half inches from the bill-tip to the tail-tip. Most of them are birds of the woods and thickets, a few only venturing into the open country. The Warbler's bill is longer than that of most small birds and is well adapted for seizing the softbodied insects upon which it so largely preys.

One of the most common members of the family in the Eastern States is the Chestnut-sided Warbler. The general appearance of the male is that of a particularly trim little bird with olive-green back and bright yellow crown; the under parts are lighter, and the sides are marked by deep chestnut-that is the way the male looks in spring, at which season 
the female is quite similar, although its colors are duller. In the fall and winter the plumage presents a very different appearance. The upper parts then are yellowish olive-green sometimes with faint streaks on the back. The deep chestnut of the sides has given way to a few spots or patches of this color.

In seeking the Chestnut-sided Warbler one should go to woodlands that have been cut over and grown up in bushes.

Haunts There are found the conditions which this bird dearly - loves, and in such a situation one may pass a whole forenoon and seldom be out of sight or hearing of one or more examples of it.

The nest of this Warbler is made of strips of bark, soft, dead leafstems and similar materials. It is lined with tendrils and rootlets, and usually is placed in a small tree or bush two and a half to three and a half feet above the ground. Rarely have I found one so situated that it could not be readily reached by the spring of an agile house-cat, and there is much evidence to prove that many are annually pulled down by these feline hunters.

It is commonly reported that as many as five eggs are deposited in the nest before the bird begins sitting, but fully three-fourths of those nests that I have found contained only four eggs. In color they are white, with numerous brown markings of various shades, some distinct, others

Nest and

Eggs

more or less obscure, as if the inside of the shell had been painted and the color was showing through. The spots and blotches are gathered chiefly in a wreath about the larger end. They are pretty, dainty, little objects, as is the case with all Warblers' eggs, about two-thirds of an inch long and half an inch in thickness at the largest place.

The Chestnut-sided Warbler feeds almost exclusively on insects. John James Audubon wrote that he once, in Pennsylvania, during a snowstorm in early spring, he examined the bodies of several of these birds, and that he found that their stomachs contained only grass-seeds and a few spiders. The birds were very poor, and evidently were in a half-starved condition, which would probably account for the fact that they had been engaged in so un-warblerlike an act as eating seeds. Ordinarily this Warbler is highly insectivorous, and feeds very Insect

Food largely upon leaf-eating caterpillars. It also collects plant-lice, ants, leaf-hoppers, small bark-beetles, and in fact is a perfect scourge to the small insect-life inhabiting the foliage of the bushes and trees where it makes its home. Sometimes the birds take short flights in the air after winged insects. It will thus be seen that the Chestnut-sided Warbler has a decided value as a guardian of trees, which is reason enough why the legislators of the various States where the bird is found have been induced to enact the Audubon Law for its protection.

The song of the Chestnut-sided Warbler is often confused in the ears 


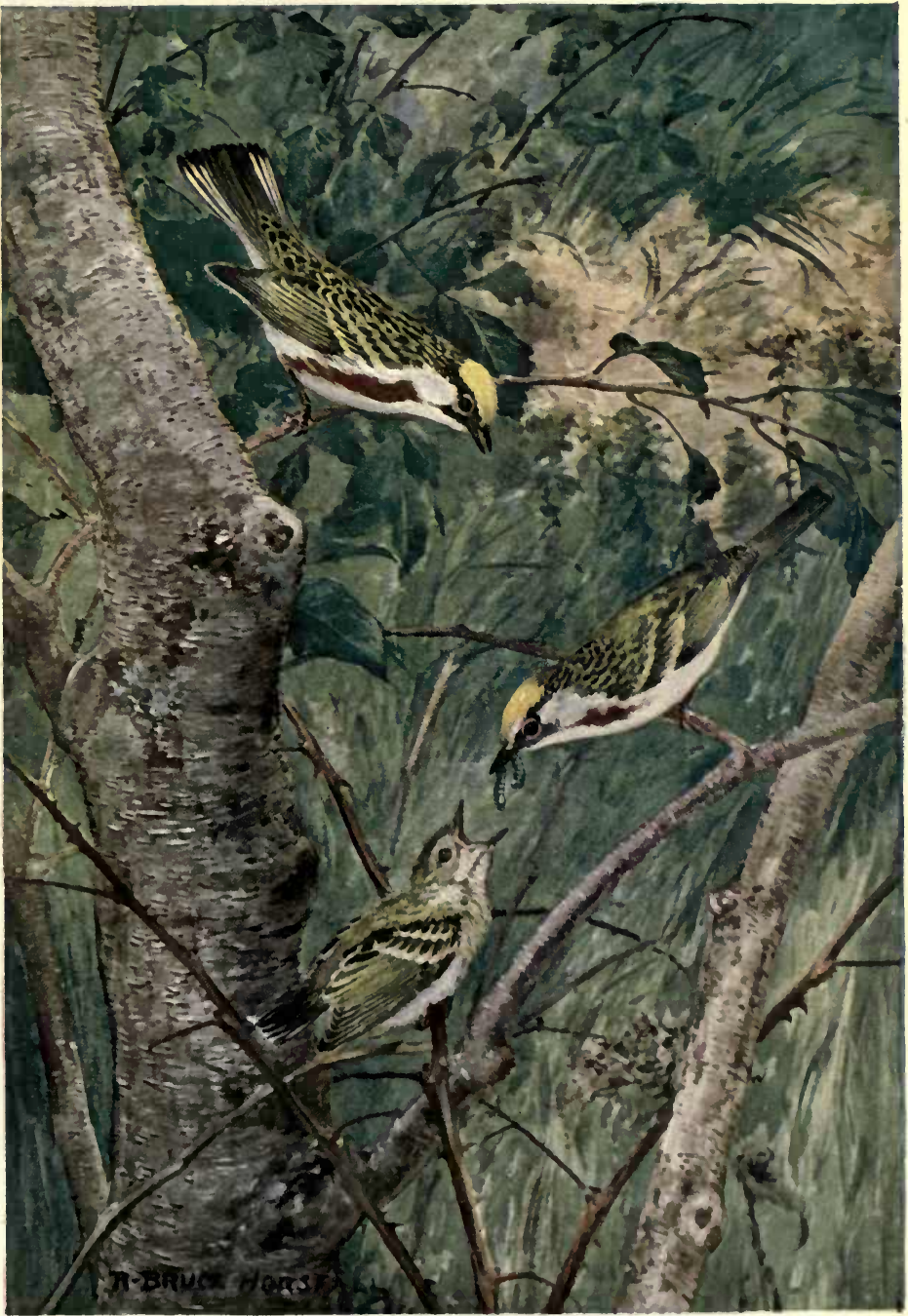

CHESTNUT-SIDED WARBLER

Order-PASSERES

Genus-DENDROICA
Family-MNIOTILTIDA

Specles-PENNSYLVANICA

Nattonal Assoclation of Audubon Societies 

of listeners with that of the Yellow Warbler. Mathews says the song resembles the words: "I wish, I wish, I wish to see Miss Beecher."

All birds that depend so much on insects for their livelihood as do the Chestnut-sided Warblers are necessarily highly migratory. By the middle of September nearly all of them have departed from their summer home, which covers the territory of the southern Canadian Provinces from Saskatchewan eastward, and extends southward as far as Ohio and New Jersey. They are also found in summer along the Alleghany Mountains in Tennessee

\section{Migration}

and the Carolinas. Most of the migrants go to Central America by way of the Gulf of Mexico, only a comparatively small number traveling to Florida and the Bahama Islands.

Mr. Clinton G. Abbott, writing in Bird-Lore in 1909, told most entertainingly of the fortunes of a pair of these Warblers and their nest, which he watched one summer. After describing discovering a nest from which all the eggs had been thrown but one, and in their place had been deposited an egg of the Cowbird, he says:

"It was sometime during the night of July 13-14 that the first of the remaining two eggs hatched-the Cowbird's of course. The Warbler's hatched between twelve and twelve-thirty on the fourteenth. The nicety with which matters had been so arranged that the young Cowbird would have just a convenient start in life over its unfortunate rival commanded my admiration if not my sympathy. Cowbirds must indeed be sharp nest-

An Unbidden

Guest finders to be able to discover at short notice not only the nests of certain suitable kinds of birds, but even nests containing eggs at a certain stage of incubation.

"After the hatching of the eggs I spent considerable time at the nestside, and observed with interest the many pretty little incidents of a bird's domestic life-the constant and tender brooding of the newly hatched young by both Warblers in turn; the never-ceasing search among the neighboring trees and bushes for small caterpillars; the delivery of the food by the male to the brooding female, who in turn would raise herself and pass it to the young; the careful cleansing of the nest; and many other intimate details of the birds' loving and happy lives. When I drew aside the leaves that sheltered the nest, and allowed the sun to shine upon it for purposes of photography, the mother, realizing with that wonderful instinct com-

Motherly

Care mon to all birds which nest in the shade, the fatal effect on her babies of the sun's direct rays, would take her stand on the edge of the nest and with outstretched wings would form of her own body a living shield for the comfort and protection of her young.

"As the young birds began to grow, the Cowbird not only maintained, but rapidly increased its lead over its small nest-mate. At ever visit of the parent bird with food, its capacious gullet could be seen violently 
waving aloft and almost completely hiding the feeble little mouth of the Warbler, whose owner was pathetically doing his best in a dumb appeal for food. The Cowbird's appetite seemed never to be satiated and, unlike most nestlings, which relapse after a meal and give their brethren the next chance, he seemed ready for every fresh opportunity; and by reason of his superior display he usually succeeded in obtaining the coveted morsel.

\section{The Lion's Share}

However, the young Warbler did manage to get an occasional portion, and I had strong hopes that he might reach maturity, for I realized that a Chestnutsided Warbler's usual laying is about five eggs, and that therefore some four eggs must have been made to give place to the two Cowbirds. Hence the young Cowbird in the nest might reasonably be granted the room and food of four young Warblers. More than this I hoped he was not getting.

"On July 18 at $3: 30$ P. M. when the birds were about four days old I took them from the nest to compare their sizes. I replaced them in the nest but that was the last I saw of the poor little Warbler. When I returned at 5 P. M. the Cowbird was in sole and triumphant possession of the nest. Just what became of the Chestnut-sided Warbler will never be known, but my theory is that, weakened by lack of sufficient food, the little fellow at last became too feeble to raise himself at all, and was crushed to death by the Cowbird's gross body.

"The Cowbird now had things all his own way, and,

Success

there being no one to dispute his right to all the food,

he grew with amazing rapidity. The dainty little cup of a nest, never built to accommodate such a monster, was soon completely forced out of shape. His body then protruded beyond the lower rim of the nest, and the ground underneath became littered with droppings quite baffling the cleanly, sanitary instincts of the Warblers.

"The Cowbird, now almost twice as large as his devoted foster parents, rises with hideous chitterings of delight to receive an ever-acceptable meal. I visited the nest at 7:30 A. M. on July 26 . As I walked home to breakfast, I resolved that in the interests of justice I ought to put an end to that Cowbird as a murderer and a menace to the welfare of birddom. But when I returned to the spot, about 9 A. M., he had escaped me; the nest was empty, my bird flown."

\section{Classification and Distribution}

The Chestnut-sided Warbler belongs to the Order Passeres, Family Mniotiltide and Genus Dendroica. Its scientific name is Dendroica pennsylvanica. It lives and breeds in summer throughout the northern United States and southern Canada as far west as the edge of the Plains. It winters in Central America.

This and other Educational Leaflets are for sale, at 5 cents each, by the National Association of Audubon Societies, 1974 Broadway, New York City. Lists given on request. 


\section{THE REDSTART}

By T. GILBERT PEARSON

\section{The National Association of Audubon Societies}

\section{Educational Leaflet No. 86}

Of all our warblers, extremely active birds though they are, not one displays so many different motions in one short minute as a Redstart. It dashes to and fro, up and down, in and out of the shrubbery, hither and yon, with an infinite variety of movements like some brilliant, intoxicated butterfly, whose exuberance and energy are utterly boundless. It is a small bird, only about four and three-quarters inches long, but by

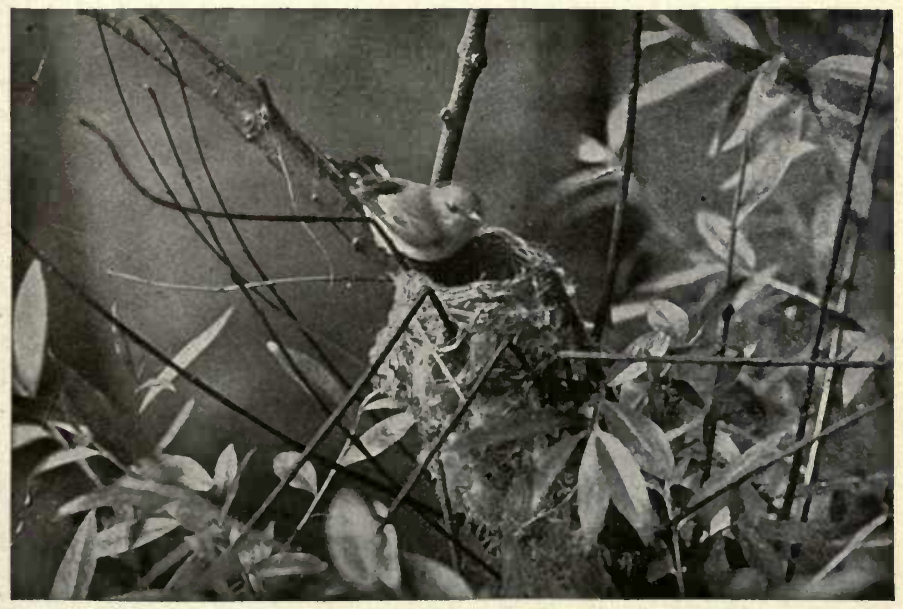

A FEMALE REDSTART AT HER NEST

its song and activity it keeps itself much more in evidence than many a bird twice its size.

"Ching, ching, chee; ser-zuee, swee, swe-e-e, he sings, and with wings and tail outspread whirls about, dancing from limb to limb, darting upward, floating downward, blown hither and thither like a leaf in the breeze; but the gnats dancing in the sunlight and the caterpillars feeding in the shade of the leaves know to their sorrow that his erratic course is guided by a purpose."

So writes Frank M. Chapman.

All during the song-season the male Redstart makes his presence known, for be is an unusually constant singer and may be heard at almost 
any time of the day. Some observers say he has two distinct songs, others say he has three, while still others aver that the bird has as many as five or six. Gerald Thayer, I believe, is authority for the statement that about his home at Monadnock, New Hampshire, the Redstarts have what he considers three comparatively constant songs, which serve as the basis for all other varieties of their music.

For my part I have found the Redstart's song to be bewildering and difficult of identification more times than I care to admit. When in spring I find myself in a locality where Warblers are singing, if I can remain there a day or two and learn what species are in song, and watch, and think hard, my memory is at length refreshed to the extent that I

A Puzzling Song soon begin to feel sure of distinguishing the Redstart's tune with some degree of confidence. Others have guardedly hinted that they have experienced similar difficulty in remembering from year to year the Redstart's notes.

It is certainly true that to any but those with particularly gifted ears the song of this bird lacks any striking characteristic, such as we all readily recognize in that of many others-the Ovenbird, for instance, or the Wood Thrush.

The nest of the Redstart is made of leaf-stalks, thin strips of bark, plant-down, and similar soft vegetable materials, and usually is lined with fine rootlets or delicate tendrils. Apparently it is always placed in the crotch of a sapling two to fifteen or twenty feet from the ground. One favorite situation, in which I have often found the nest, is between a small branch, little more than a twig, and the main stem of the tree, the latter perhaps as much as three inches in diameter. In such positions the nests were frequently in plain view-after they were once discovered, Sometimes, however, the nest is so well hidden that it may be found only after a most careful and prolonged search.

The four or five eggs are white, variously blotched and spotted with brown and gray, thus resembling those of the Yellow, or Summer, Warbler. They measure about 65 hundredths of an inch long by 50 hundredths wide.

Last spring it became apparent that a pair of Redstarts had a nest hidden somewhere within the recesses of a certain limited growth of

\section{A Hidden Nest} saplings near our summer camp on Lake Champlain. Spying on the birds and watching their movements proved fruitless, the thick foliage blotting out all vision of the female in every instance when she was seen approaching.

Meanwhile the male sang daily and hourly, and almost every ten minutes, from his perch on a large tree near by. Every sapling was searched in turn until at last the nest, hidden by leaves, came in sight, in a crotch twelve feet from the ground.

"The young males of this species," Audubon notes, "do not possess the brilliancy and richness of plumage which the old birds dispiay until the second year, the first being spent in the garb worn by the females: 


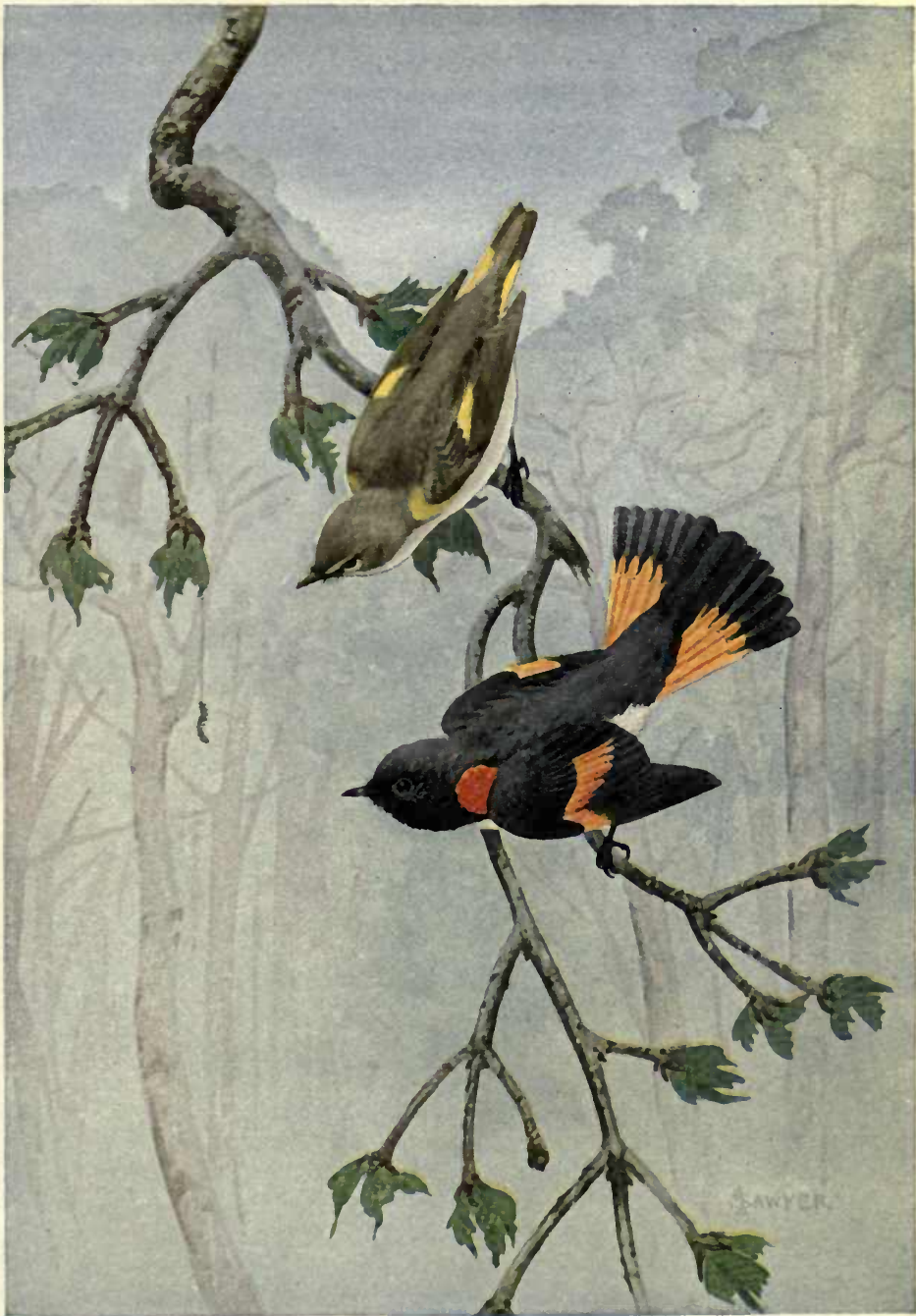

REDSTART

Order-PASSERES

Genus-Setophaga
Family-MNiotiltid

Species-RUTiciLLA

National Assoclation of Audution Societies 

but, toward the second autumn, appear mottled with pure black and vermillion on their sides. Notwithstanding their want of full plumage they breed and sing the first year like the old males."

Mr. E. H. Forbush has written in his book, "Useful Birds and Their Protection":

"The insect-food of the Redstart is perhaps more varied than that of any other common Warbler. Apparently there are few forest insects of small size that do not, in some of their forms, fall a prey to this bird. Caterpillars that escape some of the slower birds by spinning down from the branches and hanging by their silken threads are snapped up in midair by the Redstart. It takes its prey from trunk, limbs, twigs leaves, and also from the air, so that there is no escape for the tree-insects which it pursues unless they reach the upper air, where the Redstart seldom

Chase of

Insects

goes, except in migration. It has been named the fly-catcher of the inner tree-tops, but it is a fly-catcher of the bush-tops as well.

"While there are few small pests of deciduous trees that it does not eat in some form, it is not confined to these trees, but forages more or less among coniferous trees. Also it is seen at times in orchards, and gleans among shade-trees in localities where the woods are cut away. It is impossible to weigh the pros and cons of this bird's food, for no thorough examination of it has ever been made. It is an efficient caterpillar-hunter, and one of the most destructive enemies of the smaller hairy caterpillars. It catches bugs, moths, gnats, two-winged flies, small grasshoppers, and beetles. It probably secures a larger proportion of parasitic hymenoptera and diptera than most other Warblers, occasionally destroying a few wasps; otherwise its habits seem to be beneficial."

The summer home of the Redstart extends as far northward as Labrador and southern Alaska; in fact, it goes almost to the limit of tree-growth throughout Canada. The southern boundary of its breeding range may be roughly traced by a line extending from the North Carolina Mountains to Utah, and thence northwesterly to Washington.

As this species is highly insectivorous it must depart from the land of frost upon the approach of winter. Therefore, Redstarts migrate southward through the Southern States. Many in the East follow down the peninsula of Florida and then fly across to Cuba, Haiti, and other islands of the West Indies, where they pass the winter. The larger number, however, reach the sea at various points along the western coast of Florida, and in Mississippi, Louisiana, and eastern Texas, where they pause only long enough to supply themselves well with food, and then at the close of day start out boldly across the Gulf of Mexico. Their journey to

Migrations

Yucatan or to western Cuba is made in a single night, although in some cases the distance is six or seven hundred miles.

Many of these Warblers pass their winter in the Gulf-shore region of southern Mexico and Central America, but many others push on by the land-route to northern South America, and remain there, living luxuriantly on the abundant insect-life of the tropics until the spell of the 
mating season begins to come over them. Then, follawing the general lines of the migration-routes by which they went south, they turn their wing-beats back toward the northern United States and Canada.

Here are some of the dates when Redstarts have been known to reach different points along the Atlantic seaboard during their spring migration: Southern Florida, April 3; Atlanta, Georgia, April 6; Englewood, New Jersey, April 26; Portland, Connecticut, May 3; Durham, New Hampshire, May 10; Nova Scotia, May 21. From this it would appear that it takes about six weeks for the birds to journey from south-

Travel- ern Florida to their summer home in southern Canada.

Routes Of course they could make this trip much more quickly if it.was necessary, but they follow the opening of the spring and the consequent reappearance of insect-life.

Somewhat similar facts have been recorded of the coming of the Redstarts that pass up the Mississippi Valley, as are indicated by the following data of the first appearance at different localities along the inland route:- New Orleans, Louisiana, April 5; St. Louis, Missouri, April 17; Oberlin, Ohio, April 27; Lake Forest, Illinois, May 3; Columbia Falls, Montana, May 20.

As the Redstart is a beautiful, attractive, and exceedingly useful bird, it is perfectly apparent that the legislatures of the various States, as well as Congress, have been wise in enacting laws for their protection. In virtually every State where the bird is found the Audubon Law has been written on the statute books. No one should ever kill a Redstart.

The Painted Redstart (Setophaga picta) is a closely related species, which is mainly Mexican in its habitat, but appears north of the Mexican border in southern Arizona and New Mexico. It has a gaudy beauty-lustrous black, with a large white patch on the wings, white edging on the tail, and the middle of the breast and abdomen rose-red. It occupies the valleys and canyons among the foot-hills of mountains, where a

Painted

Redstart

sparse growth of oaks seems to favor its habits. "Their motions," H. W. Henshaw writes of these birds, "are almost an exact reflection of those of the common Redstart, which they so much resemble in form."

Mr. Henshaw was unable to find the nest of this southwestern Redstart; but it is now known to be placed on the ground, usually concealed under some overhanging stone or stump amid shrubbery, and preferably in a stream-bank. The nests are made of finely shredded materials and lined with hair. The eggs are white, dotted with reddish brown.

\section{Classification and Distribution}

The Redstart belongs to the Order Passeres and Family Mniotiltide. Its scientific name is Setophaga ruticilla. It breeds in the Northern States and in southern Canada east of the plains; and winters in the West Indies and central America.

This and other Educational Leaflets are for sale, at 5 cents each, by the National Association of Audubon Societies, 1974 Broadway, New York City. Lists given on request. 


\section{THE VEERY}

BY T. GILBERT PEARSON

\section{The National Association of Audubon Societies Educational Leaflet No. 87}

The Thrushes are rated very high as song-birds, and each has a song so distinct in itself that once perfectly heard it need never be forgotten nor confused with the song of any other. One of America's most popular members of this family is the Tawny or Wilson's Thrush, usually known as the Veery. It was called Wilson's Thrush by Prince Lucien Bonaparte, who was a great admirer of Alexander Wilson, and the editor of his "Ornithology." The name "Veery" is an imitation of its ringing calls. To the novice in bird-study the various

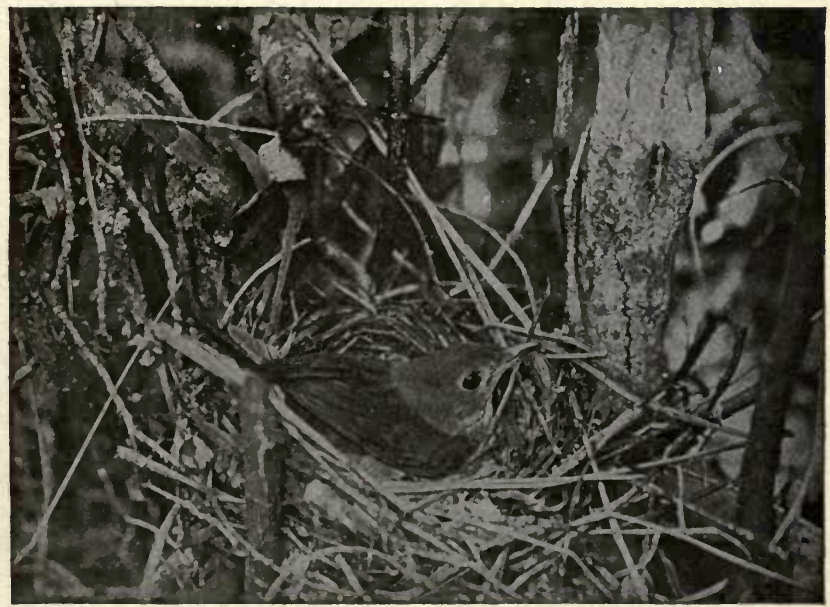

A VEERY MOTHER BROODING HER EGGS

small Thrushes are somewhat confusing. The Veery has often been mistaken for the Wood Thrush, despite the difference that the latter has distinct rounded black spots on its breast, and the Veery has small and somewhat indistinct arrow-shaped spots on its breast and sides.

There is no mistaking the Veery's song, however. It is one of the most melodious of the northern woodlands, and during the spring migration is frequently heard on still days in the forests and groves of the South. It begins singing shortly after its arrival in May and usually stops early in July. There have been many attempts to describe the Veery's song, and numerous writers have tried to spell it out in words. 
To my mind all such attempts are woefully inadequate. Perhaps the best description of its song is that given by Ridgway, who refers to it as "an inexpressible, delicate, metallic utterance of the syllables ta-weelah, twil-ah, twil-ah, accompanied by a fine trill." The first part of the song is louder than the ending - in fact the song seems to start off with a burst of energy that diminishes before the end of the performance. To me the song has always suggested a sort of ethereal trill, as if the

An Ethereal Trill notes came through a spiral, silvery pipe; there is something suggesting infinite space and vast distance in their exquisite quality. Although the song carries well, it frequently happens that when one is near the performer, but does not see it, he thinks the bird a considerable distance away.

The Olive-backed Thrush has a song which may be described as a poor imitation of that of the Veery; but once listen to a Veery on a long summer evening and you will never afterward mistake the Olive-backed Thrush for the Veery.

This bird knows well how to hide her nest, and unless, perchance, you should see her carrying building-materials, or should discover one of the parents taking food to the young, you are not likely to learn her secret. Probably the majority of nests that are seen are found by flushing the bird from her eggs as the observer makes his way through the woodland.

On June 18, 1914, I found myself in a good Veery country along the western shore of Lake Champlain. The constant singing of these Thrushes, especially in the early morning and late afternoon and evening, awakened a strong desire to learn more of the private life of these particular birds. Just as you always feel that you know a man better after having seen his home, so do you feel on much more intimate terms with a wild bird after having looked upon the cradle it has built for its young. We are in the midst of the woods and the Veeries were on every side. So I started gaily forth to hunt a nest, but the

Hunting a Nest day ended in failure, as did also the next and the next. In desperation I wrote to a very wise gentleman of my acquaintance and asked him how in the world I was to find a Veery's nest.

"It is a very simple matter," he wrote, "if you will keep your eyes open. The nest is always on the ground or very near it. Look at the foot of trees or stumps, especially in growths of young sprouts, on logs or stumps, in thick places or among plants on a steep hillside. Search only in the woods and especially where it is damp."

I read this and found that I knew just exactly as much as I did before, for I had seen all this in bird-books over and over again. So I thanked him for his kindness and went out into the woods once more. For two or three hours every day for two weeks the search went on, and not the slightest sign of a nest could I find. Yet the Veeries had nests, or had had nests, for during this time I came upon no less than fourteen young, 


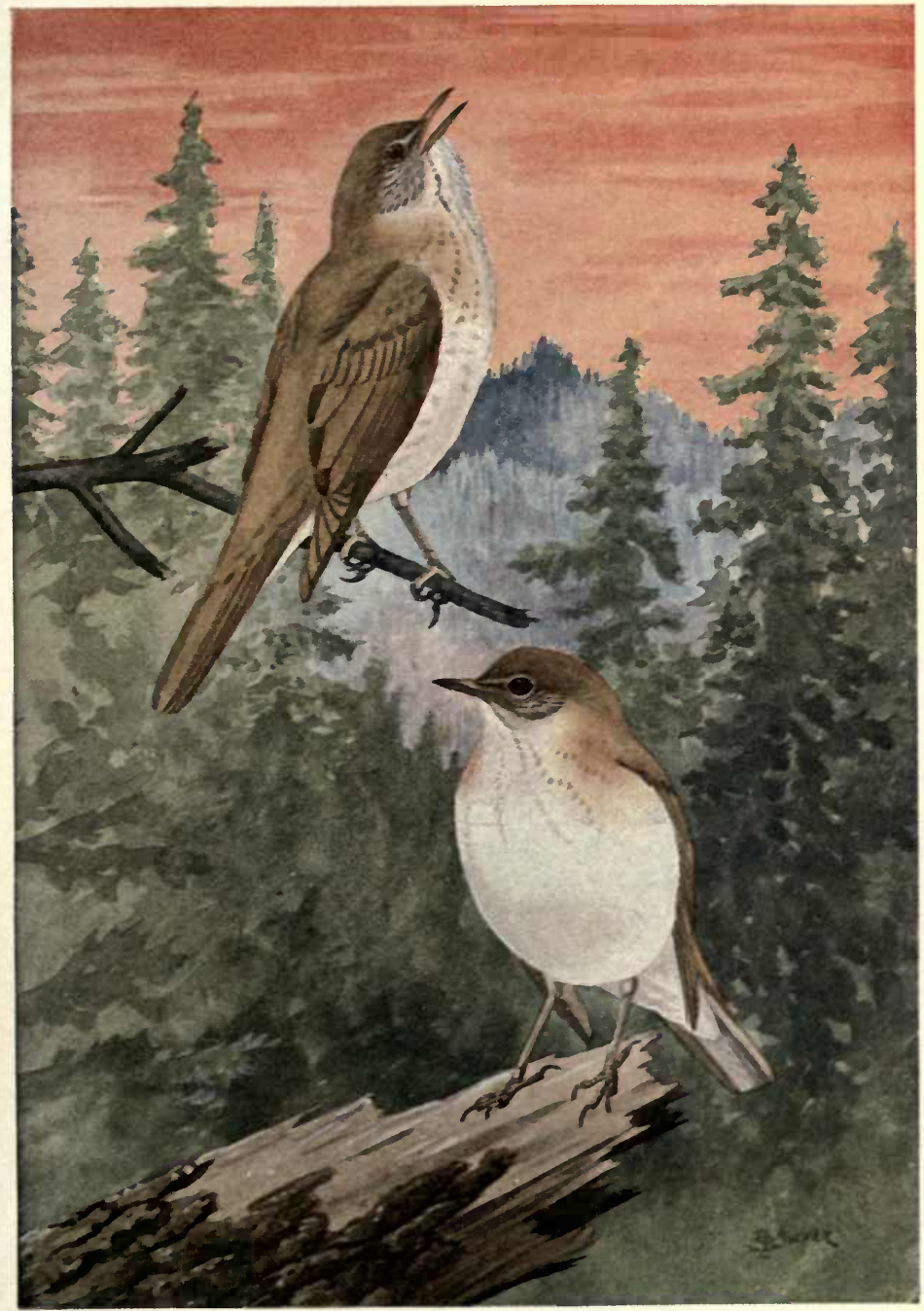

THE VEERY

Order-PASSERES

Genus-HYLOCiCHLA
Famlly-TURDIDE

Species-ruscescens ruscrscans 

as yet unable to fly. They were always perched in the bushes a few feet from the ground, and usually one or both of the parents at once discovered me.

This recalled Miss Florence Merriam's saying, in her "Birds of Village and Field," that the Veery is a peculiarly companionable bird to those who live near its haunts. "It will become so tame," she tells us, "as to nest close to a house if not disturbed, and when sought in its natural woodland home will meet your friendly advances with confidence, answering your whistle with its own sweet, wavering whee-u, till you feel that the woods hold gentle friends to whom you will gladly return."

The next summer found me again in these woods, prying into every thicket and clump of sprouts where a Veery might hide, and then at eight o'clock on the morning of June 19, I came upon a bird sitting on her nest. With the greatest caution I withdrew, only to go again the next day, and the day following, hoping to find her away. On the fourth trip, when I peeped into the hiding-place I found her gone. Drawing the bushes aside I advanced and looked into the nest. It was empty. On the ground I found three eggs. They were deep blue, unspotted, and resembled the eggs of a Catbird, but were smaller. Every one had a large section of the shell cut away and there was no sign of its contents.

Nest and Eggs Surely the red squirrel I had frequently seen near by had wrought this mischief-at least, in my disappointment, I laid the blame at his door.

This nest rested among the top limbs of a little brushpile, and was just two feet above the ground. Sone young shoots had grown up through the brush and their leaves partly covered the nest from view. It had an extreme breadth of ten inches and was five inches high. In its construction two small weed-stalks and eleven slender twigs were used. The nest was made mainly of sixty-eight large leaves, besides a mass of decayed leaf-fragments. Inside this bed was the inner nest, two inches and a half wide, composed of strips of soft bark.

The Veery, in common with a large number of other birds, builds a nest open at the top. The eggs, therefore, are often more or less exposed to the Crow, the pilfering Jay, and the egg-stealing red squirrel. This necessitates a very close and careful watch on the part of the owners. At times it may seem that the birds are not in sight, and that the eggs are deserted, but let the observer go too near and invariably one or both old birds will apprize him of their presence by voicing their resentment in loud cries of distress.

The Veery is not among the first-comers in Spring, but appears in the United States from its winter home in the tropics about the first of May. The species is then scattered during the summer from Colorado to Labrador, where Audubon mentions finding it; but it is rarely seen or heard south of New York City and the Great Lakes, except in the mountains, until it returns, southward flying, in the autumn.

It may be found, however, even in the prairie-country of the North- 
west, as Dr. Elliott Coues has described in his "Birds of the Colorado Valley"- a paragraph quoted because it suggests where many birds may be living hardly suspected by prairie-dwellers. Doctor Coues says:

"The heavy growth of timber that fringes the streams includes many nooks and dells, and broken ravines overgrown with thick shrubbery, from out the masses of which the tall trees tower, as if stretching forth their strong arms in kindly caressing of the humbler and weak vegetation, their offspring. In such safe retreats, where the sombre shade is

Western

Haunts brightened here and there with stray beams of sunlight, in the warmth of which myriads of insects bathe their wings and flutter away their little span of life, humming a quaint refrain to the gurgle of the rivulet, the Veery meets his mate-the song rises-the wooed is won-the home is made.

"Should we force our unwelcome presence upon the bird who is brooding her newly-found treasures with the tenderest solicitude, she will nestle closer still, in hope of our passing by, till we might almost touch her; when, without a word of remonstrance or reproach, she takes a little flight, and settles a few yards away, in silent appeal."

Mr. E. H. Forbush, who has studied much the food-habits of this bird, and who never permits his enthusiasm for a species to lead him away from an accurate appreciation of its economic value, has this to say:

"The Veery feeds very largely on insects. Those which frequent the ground and the lower parts of trees are commonly sought. Ants, ground-beetles, curculios and grasshoppers are favorites. It goes to the field sometimes at early morning, probably in search of beetles, cutworms, and earthworms. It has been seen, now and then to eat the hairy caterpillars of the gipsy-moth. It feeds conUtility siderably in the trees, and so takes many caterpillars; but is not usually seen much in gardens or orchards, except such as are situated near woods. In summer and fall it eats wild fruit, but seldom troubles cultivated varieties."

The Veery is not a very large bird even for a Thrush. Its total length from bill-tip to tail-tip is about seven and one-half inches. As a Robin is ten inches long, it will be seen that the Veery is decidedly a shorter bird than our more common door-yard friend. When the wings are spread to their greatest extent, the Veery measures about twelve inches across and the Robin sixteen inches. As the English Sparrow is six and three-tenths inches long, it would not be far wrong to say that in size the Veery is about halfway between an English Sparrow and a Robin.

\section{Classification and Distribution}

The Veery belongs to the Order Passeres and the Family Turdida (Thrushes). Its scientific name is Hylochichla mustelina. It breeds in the northern border of the United States and throughout southern Canada, southward in the Alleghany Mountains to North Carolina, and westward to the eastern valleys of the Rocky Mountains. It winters in the West Indies and northern South America.

This and other Educational Leafiets are for sale, at $\mathbf{s}$ cents each, by the National Association of Audubon Societies, 1974 Broadway, New York City. Lists given on request. 


\section{THE AVOCET}

By T. GILBERT PEARSON

\section{The National Association of Audubon Societies} Educational Leaflet No. 88

Among the American shore-birds the one that stands out as the most showy of them all is the Avocet. It is, indeed, of most striking appearance. Its white body, and black, white-striped wings, render it conspicuous at a great distance, and its large size has made it a coveted target for gunners ever since the time when white hunters in America first began to go afield.

From the point of its biil to the end of its tail the Avocet measures

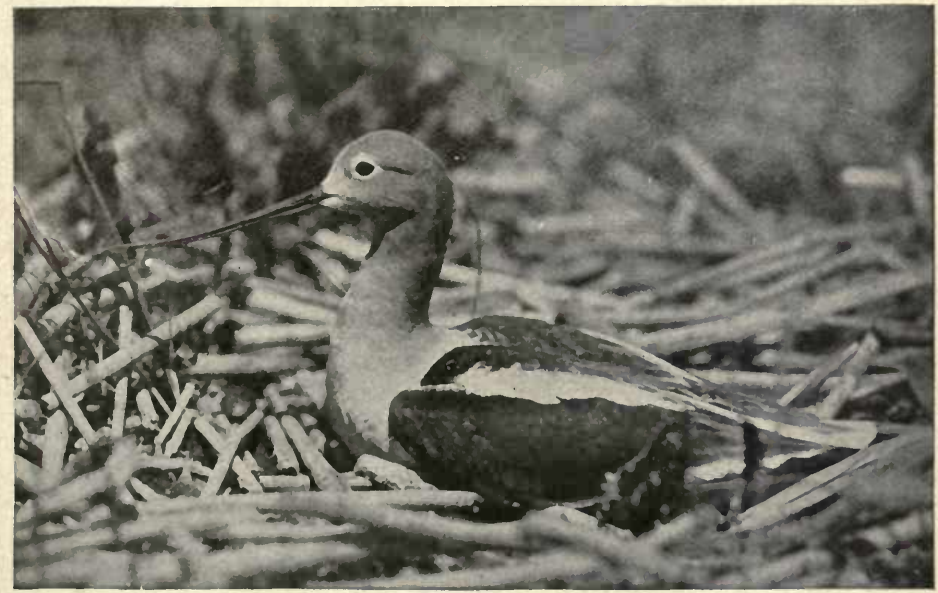

THE AMERICAN AVOCET

Photographed by H. T. Bohlman

sixteen to eighteen inches, and when the wings are spread the distance from tip to tip is fully twenty inches. The long, upward-curving bill is a form extremely unusual among birds; and the partially webbed feet enable it to swim with ease; when, in searching for its food, it advances into water where the bottom is beyond the reach of its long legs. The color of its fect and legs explains the name "Blue Shanks" by which it is known to many sportsmen.

While searching for wild ducks' nests in the marshes of the Klamath River, in southern Oregon, in company with William I. Finley and R. Bruce Horsfall, I came upon several groups of these magnificent 
birds. In every case they were probably nesting in the neighborhood, for by their actions they plainly expressed their displeasure at our approach. At first two or three would be seen, but their cries soon brought others, perhaps their mates, who left their nests to come and help expel the intruders. With shouts of distress they circled us, or flew about in the air overhead, and occasionally would alight and go bumping along the ground as though injured and undergoing the most frightful suffering. Sometimes they would settle in the water, where their antics of head-bobbing and wing-waving were most amusBehavior ing. Again they would submerge the body, and, with the head laid out on the surface, would propel themselves forward much as wounded wild geese will sometimes do.

It was not given to us to find their nests that day, nor the next, but shortly afterward several were discovered by Mr. Finley in this neighborhood.

The nest of the Avocet is merely a slight depression in the marsh lined with grass, and there the spotted and blotched eggs are laid, and the young first see the light of day. In common with other waders, the little Avocets have the power of running about and picking up food very shortly after they are hatched.

I have had the good fortune of observing these birds about many of the lakes of the Plains, and in the mountain-valleys of the far West, and everywhere they have displayed the same solicitude when one approaches the neighborhood of their nests.

It is rather remarkable that so little has heretofore been written regarding the habits of the Avocet, and it is evident that few ornithologists have studied them carefully since the days of John James Audubon. Here is a quotation from Audubon's "Birds of North America," which not only gives some intimate details of the Avocet's life about the nest, but well illustrates the painstaking care with which this great artistnaturalist pursued his field-studies. His story deals

Audubon's Notes

with the movements of a little company of Avocets that he found breeding in a marsh about two miles from Vincennes, Indiana, in the early part of the last century.

"On alighting, whether on the water or on the ground, the American Avocet keeps its wings raised until it has fairly settled. If in the water, it stands a few minutes balancing its head and neck, somewhat in the manner of the Tell-tale Godwit. After this it stalks about searching for food, or runs after it, sometimes swimming for a yard or so while passing from one shallow to another, or wading up to its body, with the wings partially raised. Sometimes they would enter among the rushes and disappear for several minutes. They kept apart, but crossed each other's path in hundreds of ways, all perfectly silent, and without showing the least symptom of enmity toward each other, although whenever a Sandpiper came near, they would instantly give chase to it.

"On several occasions, when I purposely sent forth a loud shrill whistle without stirring, they would suddenly cease from their rambling, 


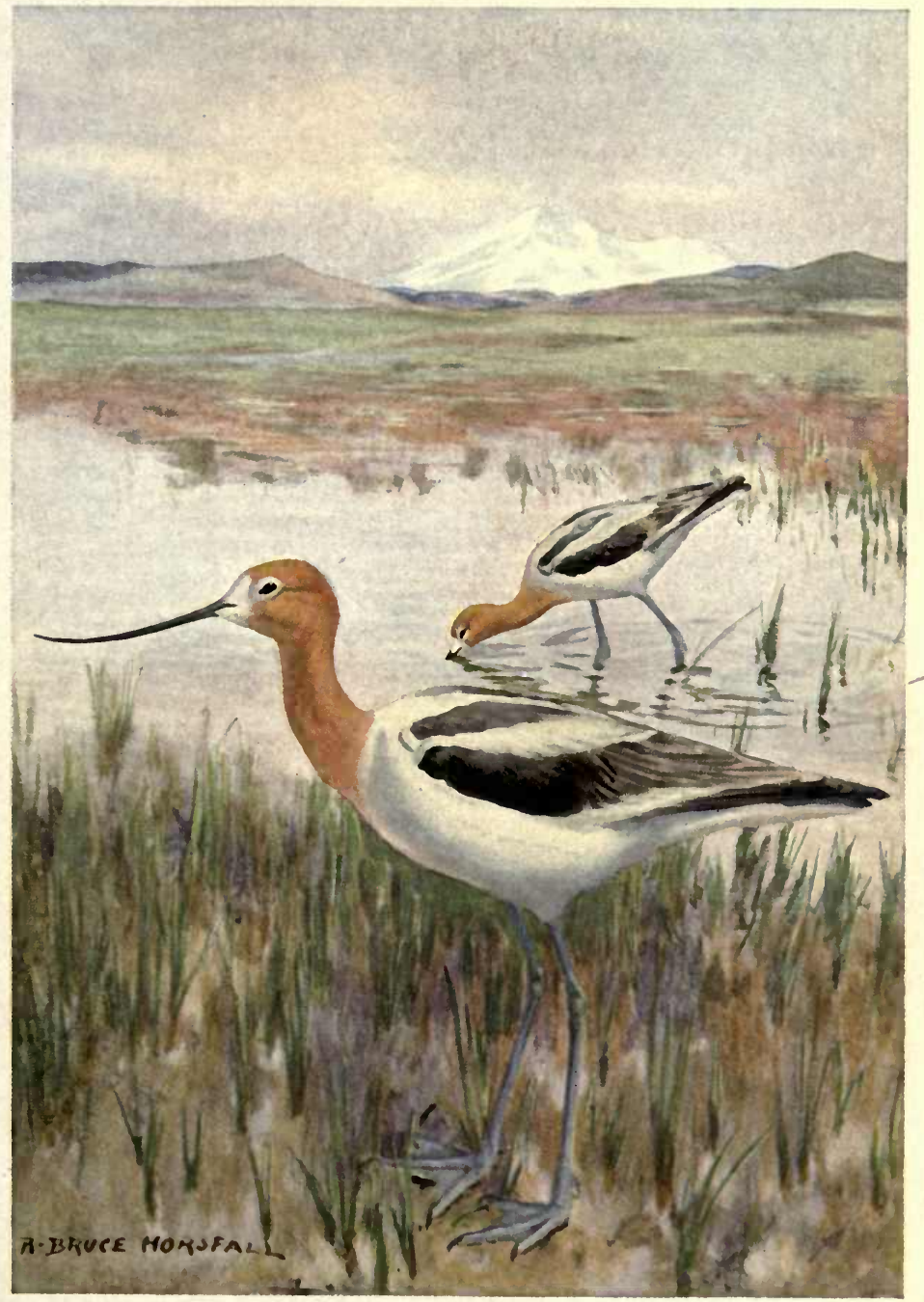

AVOCET

Order-LIMicole

Genus-RRCURVIROSTRA
Family-ReCURVIROSTRIDE

Specles-AMERICANA 

raise up their body and neck, emit each two or three notes, and remain several minutes on the alert, after which they would fly to their nests, and then return. They search for food precisely in the manner of the Roseate Spoonbill, moving their heads to and fro sideways, while their bill is passing through the soft mud; and in many instances, when the water was deeper, they would immerse their whole head and a portion of

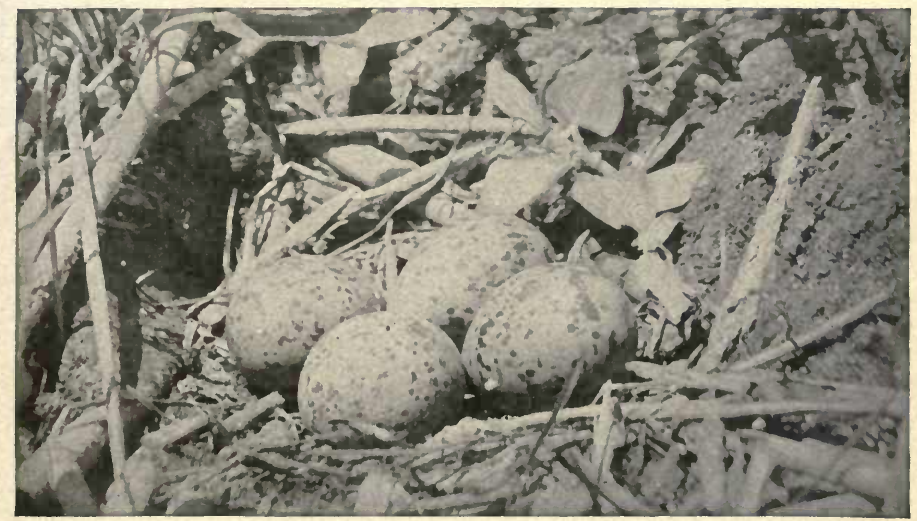

NEST AND EGGS OF AN AVOCET

Photographed by H. T. Bohlman

the neck, as the Spoonbill and Red-breasted Snipe are wont to do. When, on the contrary, they pursued aquatic insects, such as swim on the surface, they ran after them, and, on getting up to them, suddenly seized them by thrusting the lower mandible beneath them, while the other was raised a good way above the surface, much in the manner of the Black Shear-water [Black Skimmer], which, however, performs this act on the wing. They were also expert at catching flying insects, after which they ran with partially expanded wings.

"I watched them as they were thus engaged about an hour, when they all flew to the islets where the females were, emitting louder notes than usual. The different pairs seemed to congratulate each other, using various curious

\section{Feeding} gestures; and presently those which had bcen sitting left the task to their mates and betook themselves to the water, when they washed, shook their wings and tail, as if either heated, or tormented by insects, and then proceeded to search for food in the manner above described. Now, reader, wait a few moments until I eat my humble breakfast."

It is worth noting that the Avocets described by Audubon had their summer home in Indiana. In the early part of the nineteenth century the species was more or less common along the Atlantic Coast. Alex- 
ander Wilson, the ornithologist, found them breeding on the salt marshes of New Jersey, and perhaps southward.

In examining the published lists of birds for the various States east of the Mississippi, it is quite common to-day to find mention made of this bird as a "rare transient" or an "occasional visitor." Probably few, if any, are to be found at present breeding east of the Mississippi, except, perhaps in the State of Illinois. Their almost total disappearance from the eastern United States may be attributed entirely to the continuous onslaught which has been made on their ranks by gunners engaged in the shooting of shore-birds. Many Avocets yet remain in the far-western

\section{Scarcity \\ in the East}

States, and they have been known to breed in Texas. Apparently they do not breed farther north than Saskatchewan. In winter they may be met with along the Gulf Coast of the United States, and on marshy lands to the southward.

As an economic agent in destroying injurious insects or the seeds of troublesome weeds the Avocet cannot be rated high, for it gets its living in or about the water, feeding on such small forms of life as are there obtainable. It is known to eat small snails and water-insects, both in the adult and larval stages. On salty marshes it collects many worms from the muddy water through which it wades. On the other hand no one, apparently, has ever gone so far as to say that the Avocet is injurious to any of man's interests. It is deplorable, therefore, that the lakes and water-ways of the East should now be deprived of this great wader.

Only a few weeks ago I was impressed anew with the beauty of these birds. While passing down the valley of Cane Creek, in southeastern Oregon, a flock of about fifty Avocets arose and indulged in a series of evolutions which even the most casual observer would have paused to watch. In a fairly compact company they flew away for a short distance, then turned and, after coming back almost to the starting point, dived toward the earth, arose again perhaps forty Beauty yards in the air, then swung around and came back. These maneuvers were repeated at least three times. Their white and black plumage, flashing against the gray sage-brush of the desert-like mountain-side, and sharply relieved as they skimmed over the alkaline creek, made a picture long to be remembered.

Fortunately for the species, and also for us, the regulations under the Federal Migratory Bird Law now prohibit killing an Avocet. This is but one of the many wise provisions in that statute; and there is every reason to believe that the enactment of this law bespeaks a brighter day for the Avocet, as well as for many other species of shore-birds that in the past have been sorely persecuted.

\section{Classification and Distribution}

The Avocet belongs to the Order Limicola, and the Family Recurvirostrida. Its scientific name is Recurvirostra americana. It breeds from eastern Oregon and southern Saskatchewan to southern California, northern Texas, and eastward to the upper Mississippi Valley; and it winters in Texas, Mexico and Guatemala.

This and other Educational Leaflets are for sale, at 5 cents each, by the National Association of Audubon Societies, 1974 Broadway, New York City. Lists given on request. 


\section{BLACK-NECK.ED STILT}

\section{By T. GILBERT PEARSON}

\section{The National Association of Audubon Societies Educational Leaflet No. 89}

One of the characteristic birds of the shallow sloughs and grassy marshes of the western part of the United States is the Black-necked Stilt. Its distribution is not general throughout its range, for the very good reason that suitable feeding-places are few and scattered. As this bird gathers its food by running about in shallow water one would hardly expect to find it on lakes where the water is deep to the shore-line, or on those marsh-bordered lakes where the tules grow high as a man's head. It haunts chiefly little ponds where the water is so shallow that it can wade all over them.

Alexander Wilson, the ornithologist, writes: "There is a striking affinity between this bird and the common Avocet, not only in the peculiar form of the bill, nostrils, tongue, legs, feet, wings and tail, but extending to the voice,

\section{Characteristics} manners, food, place of breeding, form of nest, and even the very color of the eggs of both, all of which are strikingly alike."

There is, however, a decided difference in the color of the two birds. When the Black-necked Stilt is standing it appears to be wholly white below, and entirely black above, the line of demarcation being very distinctly drawn down each side of the neck and along the boundary formed by the lower edge of the wing in repose. This Stilt is one of the largest representatives of the Order Limicola, or shore-birds, measuring about fifteen inches from bill-tip to tail-tip. It also possesses remarkably long and very slender legs. The delicately pointed bill is not so long as that of the Avocet, and shows but slight tendency to curve upward towards the end.

In the breeding season Stilts usually associate in little communities of four to six pairs. Writing of the nesting habits of some of these birds, which Wilson studied on the coast of New Jersey early in the nineteenth century, he says:

Nesting

Habits

"About the first week in May they begin to construct their nests, which are at first slightly formed of a small quantity of old grass scarcely sufficient to keep the eggs from the wet marsh. As they lay and sit, however, either dreading the rise of the tides, or for some other purpose, the nest is increased in height with dry twigs of a shrub very common in the marshes, roots of the salt grass, seaweed, and various other substances, the whole weighing between two and three pounds. This habit of adding new material to the nest after the female begins sitting is common to almost all other birds that breed in the marshes. The eggs are four in number of a dark yellowish clay-color, thickly marked with 


\section{The Black-necked Stilt}

large blotches of black. These nests are often placed within fifteen or twenty yards of each other; but the greatest harmony seems to prevail among the proprietors."

These birds to-day may be regarded as virtually extinct in New Jersey. All those representatives of the race that come to this region to breed apparently have been either killed or driven elsewhere. Mr. Witmer Stone in his book, "The Birds of New Jersey," gives but a single record of the Stilt having been seen in that State during the past fifty years; this one was shot by a gunner at Stone Harbor, April 27, 1894. The Stilt seems equally rare at other points along the Atlantic Coast.

Rare in the East In Eaton's "Birds of New York" the author relates that "the latest New York specimens were taken fifty or sixty years ago on Long Island, some of which are now in the State Museum, the American Museum, and the collection of the Long Island Historical Society." I know of only one record for North Carolina during the past twenty years. A specimen was shot at Nag's Head in Dare County, North Carolina, in June, 1900, and is preserved in the Museum of Trinity College at Durham.

Mr. Arthur T. Wayne, who has been studying bird-life on the coast of South Carolina for nearly forty years, records in his book on the birds of that State that the only Black-necked Stilts he ever saw in that territory were on Sullivan Island about the middle of May, 1881. He expresses a belief that the four birds he saw had nests in the neighborhood of a small fresh-water pond they were inhabiting.

In southern Florida Stilts may still be met with, for they breed not uncommonly in many districts, from Cape Canaveral southward through the peninsula and the Keys. On a key near Cape Sable Bent and Job found nests with fresh eggs on May 8, 1903. In his "Birds of Eastern North America," C. J. Maynard wrote of the Florida Stilts:

"As may readily be inferred from a glance at the birds, the Blacknecked Stilts run very rapidly, but in the midst of their career they will pause suddenly, bend their long legs, and pick up something from the ground, then off again after more food. Their favorite method of feeding, however, is to wade in the shallow pools, often becoming submerged to the body, and I have frequently seen them wading in this

\section{Feeding}

Habits manner among flocks of Ducks, consisting of several species. When alarmed while in the water they will raise their long wings and rise as lightly as if on the land, and squat quietly down in groups, but each individual faces the wind, especially if it be blowing hard. They are not shy birds, as a rule, allowing one to approach within a few yards, and if the intruder go too near they will give a bow or two as if balancing themselves, then rise with a harsh scream which becomes continuous when they are badly frightened."

They are common birds in many of the Rahama Islands. Mr. J. H. Riley, writing in The Auk for October, 1905, observes: "Almost every 


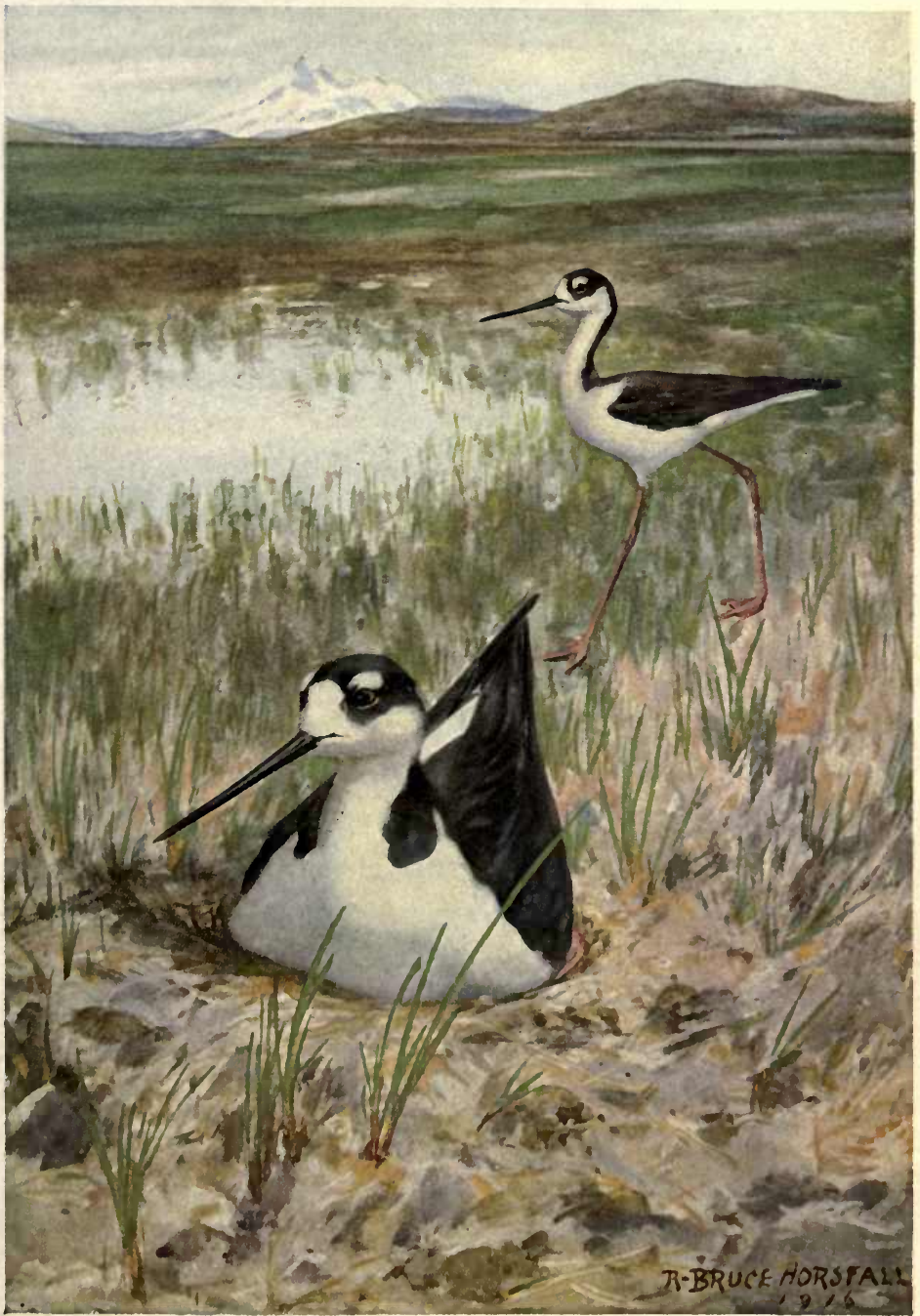

BLACK-NECKED STILT

Order-LIMICOLA

Genus-Himantopus
Family-R gCURVIROSTRIDE

Species-MEXICANUS 

small pond or island mud-flat seemed to have a few pairs wading around with stately tread until the intruder was sighted, when their infernal racket began."

In May, 1916, I found the Stilts on the Louisiana marshes between Avery Island and the Gulf of Mexico. Anticipating a visit to this territory I had expressed a hope to my friend and prospective host, Mr. E. A. McIlhenny, that he would pilot me to the nesting-grounds of these curious and ridiculously long-legged birds. Upon arriving there I was assured that this wish would be granted, as he had instructed one of the guards on the Ward McIlhenny Wild Life Reservation to begin three days before to search for a nest with eggs. Two days later the yacht bearing us passed up a deep canal through the marsh to a region where the

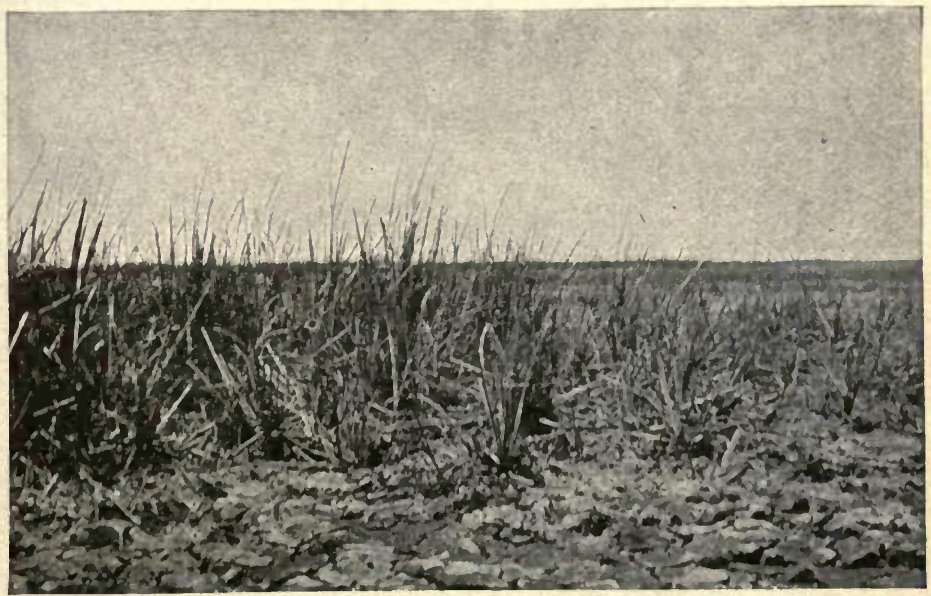

A LOUISIANA MARSH-A BREEDING HAUNT OF STILTS

grass was short, and shallow fresh-water ponds were numerous. Here Stilts were in eviclence, sometimes six or eight birds at once.

From the canal-bank the slender yellow face of the bird-warden beamed a welcome. He announced that he had found one nest, and that doubtless others were in the neighborhood. I have seldom experienced a harder task than the half-mile walk I took with the guard to see this nest. The whole region had until recently been submerged, and nearly every step was a plunge into mud knee-deep. When the long expected spot was reached the guide stooped down and parting a bunch of tall marsh-grass proudly pointed to an object beneath him. Slowly and sadly I picked it up. It was an egg of the Clapper Rail-and rotten.

This newly employed guard had not yet become familiar with the Stilt's manner of nest-building. No doubt the Stilts had nests in 
the immediate neighborhood, for they were continually flying about and calling. They had a way of alighting on the mud, where, with bent legs and drooping wings, their whole bodies would quiver as though the ague of the marshes had entered their systems. Standing there and looking over the expanse of shallow ponds and treacherous mud-flats, with the heat beating down with unbelievable force and with mosquitoes and greenheaded flies struggling among themselves for every available spot where they might sting the soft-skinned intruder, my enthusiasm waned, so we called it a day's work and returned to the yacht.

Audubon writes that while the females are sitting, the males pay them much attention, "acting in this respect like those

Behavior of the American Avocet, watching the approach of intruders, giving chase to the Red-winged Starlings, as well as to the Fishing and American Crows, and assailing the truant young gunner or egger. When there is no appearance of annoyance, they sometimes roam as far as the sea-beach. When the young are hatched, they leave the nest, and follow their parents through the grass, but on the appearance of danger squat and remain motionless."

Stilts are found in summer at various points up the Mississippi Valley. Barrows regards them as rare in Michigan and Kumlien reports them as rare stragglers in Wisconsin, but many observers record them as common in Minnesota. About the alkaline lakes and ponds of the Great Basin, farther west, they are continually seen, often in company with the Avocet. In some of the irrigated valleys of California these birds are very plentiful.

The food of the Stilt consists of small water-snails, insects, worms. and young fry of fishes. "I have frequently observed Food them," says Audubon, "running after flies, and attempting to seize the smaller Libellulæ [dragonflies]. When wounded so as to fall on the water, they are unable to dive, but on reaching the shore they run nimbly off and hide themselves."

Although this large wader is now very rare in the eastern United States it still persists in goodly numbers in the West and South, and under the protection that seems assured to it by the new Federal migratory-bird law, the species should long survive to give grace and beauty to many of the waste places of the continent.

Most of the individuals of this species leave the United States in autumn, but a few remain along the coast of the Gulf of Mexico.

\section{Classification and Distribution}

The Black-necked Stilt belongs to the Order Limicole and the Family Recurvirostride. Its scientific name is Himantopus mexicanus. It ranged originally over all North and Central America and the northern part of South America. It breeds from Oregon, Colorado, and the Gulf Coast, southward throughout the West Indies and Mexico to Brazil and Peru, and winters from the southwestern border of the United States southward.

This and other Educational Leaflets are for sale, at 5 cents each, by the National Association of Audubon Societies, 1974 Broadway, New York City. Lists given on request. 


\section{ENGLISH SPARROW}

BY T. GILBERT PEARSON

\section{Thb National Association of Audubon Societies}

\section{Educational Leaflet No. 90}

Many kinds of foreign birds have been introduced into the United States with the hope of having them become acclimated to their new surroundings. In many cases this action was taken by persons who doubtless were actuated by the desire to have around them certain forms of bird-life that they had been accustomed to see and enjoy about their European homes before migrating to these shores.

Linnets, Bullfinches, Skylarks, and many other birds, interesting on account either of their singing, or of the striking character of their plumage, have been liberated in the United States and Canada. Gamebirds, especially the Hungarian Partridge, the little European Quail, and various species of Pheasants, swell the list of foreign birds. As a rule these im-

\section{Bird \\ Imn.igrants}

ported species did not thrive in their new surroundings, and after a short time were seen no more.

The most striking exception to this rule has been the House Sparrow of Europe, which in this country has acquired the incorrect title of "English" Sparrow. The first importation of these birds appears to have been made in the year 1850 , by the directors of the Brooklyn Institute. Eight pairs were that year liberated in Brooklyn, New York. In a bulletin on the English Sparrow issued by the Department of Agriculture in 1889 a statement by the Hon. Nicholas Pike is quoted, in which he gives an account of this early attempt to naturalize English Sparrows in this country. He writes:

"It was not till 1850 that the first eight pairs were brought from England to the Brooklyn Institute, of which I was then a director. We built a large cage for them, and cared for them during the winter months. Early in the spring of 1851 they were liberated, but they did not thrive.

"In 1852 a committee of members of the institute was chosen for the re-introduction of these birds, of which I was chairman. Over $\$ 200$ was subscribed for expenses. I went to England in 1852, on my way to the consul-generalship of Portugal. On my arrival in Liverpool I gave the order for a large lot of Sparrows and song-birds to be purchased at once. They

\section{Sparrow} introduced were shipped on board the steamship Europa, if I am not mistaken, in charge of an officer of the ship. Fifty Sparrows were let loose at the Narrows, according to instructions, and the rest on arrival were placed in the tower of Greenwood Cemetery chapel. They did not do well, so 
were removed to the house of $\mathrm{Mr}$. John Hooper, one of the committee, who offered to take care of them during the winter.

"In the spring of 1853 they were all let loose in the grounds of Greenwood Cemetery, and a man hired to watch them. They did well and multiplied, and I have original notes taken from time to time of their increase and colonization over our great country."

This appears to have been only the first of many importations that followed. For example, Colonel William Rhodes of Quebec, Canada, introduced Sparrows at Portland, Maine, in 1854. Other men brought some to Peace Dale, Rhode Island, in 1858. In 1860 twelve birds were liberated in Madison Square, New York City, and four years later they

$\begin{array}{ll}\begin{array}{c}\text { Widely } \\ \text { colonized }\end{array} & \text { were introduced into Central Park. In } 1866 \text { two hun- } \\ & \text { Forty pairs were brought to New Haven, Connecti- }\end{array}$
cut, in 1867. Twenty Sparrows were turned loose in Boston Common in 1868. In 1869 the City Government of Philadelphia brought over one thousand Sparrows. In the same year twenty pairs were taken to Cleveland, Ohio, and sixty-six pairs to Cincinnati, and shortly after they were introduced in San Francisco and elsewhere in the West.

It will be seen therefore from the above records, which are not at all complete, that the present population of English Sparrows did not develop in this country from a single importation, as has sometimes been stated.

Not only were they distributed artificially, but the birds also spread rapidly by their own initiative. Their progress was made chiefly along the highways, where the droppings of horses furnished an abundant supply of half-digested grain, and along the railroads where the graincars, particularly in autumn, were continually scattering food.

At the present time there are comparatively few communities in the United States or in southern Canada where the English Sparrow is not well-known, and probably it is the most numerous species of bird in

North America. It is chiefly a bird of the cities and

A Persistent

Town-Dweller

towns, and is usually not found in abundance in the thinly populated parts of the country. In the autumn, however, when the Sparrows are most numerous, owing to recently reared broods, many of these birds are naturally forced out of the cities and towns in quest of food.

In no way does the English Sparrow show its fondness for living 11ear human habitation more than in its nesting habits. Unlike other Sparrows, it rarely if ever constructs its nest in woods, thickets, or fields, at any considerable distance from a house. During the breeding season the birds swarm in the towns and cities and there, in crevices about buildings, in water-spouts, or in boxes put up for the convenience of other birds, it makes its home. The hollows of trees are frequently used for this purpose. When such nesting-sites are no longer available, owing to overcrowding, they will build rough, bulky, covered nests among the 


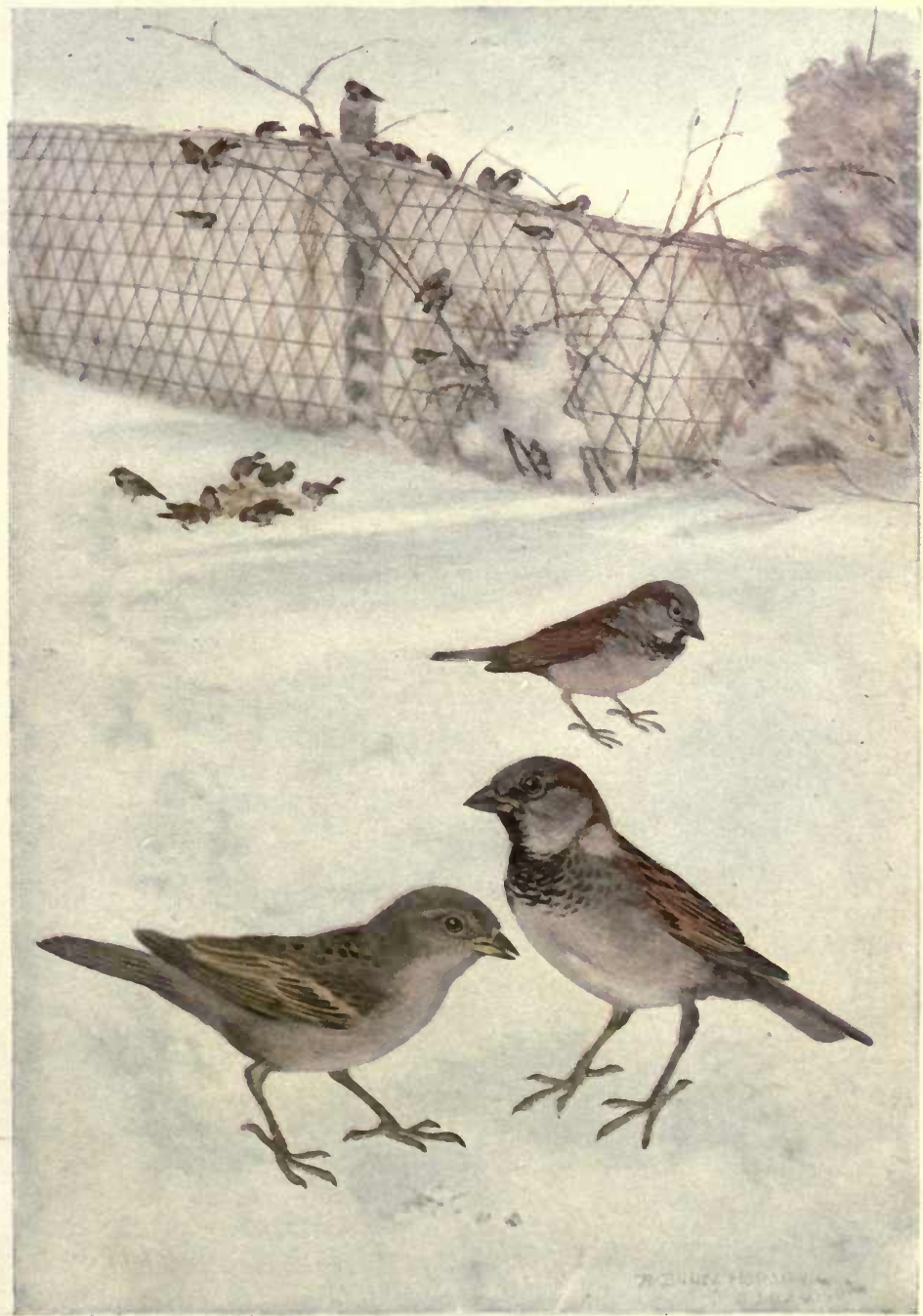

ENGLISH SPARROW 

branches of shade-trees. The materials used are straw, grass, twigs, rags, fragments of paper, or feathers; in fact almost any substance that may easily be carried.

The eggs are spotted, and usually range in number from four to six. Two or more broods are often reared in a season. The Sparrow is extremely prolific, and one evidence of its wonderful ability to avoid dangers and thrive is shown in the fact that in large cities, where destructive natural enemies are reduced to a minimum, albinism has become more and more notice-

Tendency to Albinism able. I have observed here in New York City in recent years that the number of Sparrows showing white feathers in the wings or on the body has apparently increased. If these unusually marked birds lived in the country they would, of course, be shining marks for enemies.

While primarily a seed-eater by nature, the English Sparrow is nevertheless almost omnivorous in its food-habits, and annually destroys many insects. I recall some years ago talking with two farmers in Onslow County, North Carolina, who were lamenting the fact that the law did not protect the English Sparrow, for they stated that these birds were among the most

Utility valuable species on their farms, because of their great fondness for the caterpillars that infested their tobacco plants.

An observer in the United States Department of Agriculture recently found that in Utah these Sparrows were feeding their young largely on the cutworms and other young insects that were then a scourge to the alfalfa fields of northern Utah. Other observers in various parts of the country have pointed to instances where the English Sparrow was of decided economic value. These cases, however, appear to be comparatively isolated ones, and are regarded by our agricultural experts in Washington as being greatly over-balanced by the injury these birds do.

Most persons who have tried to cultivate gardens or small fruits in the neighborhood of towns or cities, are ready to testify to the annoyance they have experienced by English Sparrows eating tender plants, such as new peas and young lettuce, as well as in the destruction of such fruits as cherries, pears, grapes, and peaches. They also frequently destroy buds and flowers of cultivated shrubs and trees.

The United States Department of Agriculture scientifically investigated the contents of the stomachs of a large number of English Sparrows, and reported that, aside from the destruction of weed-seeds, very little is to be said

Insect

Food in the English Sparrow's favor. In reference to the insects destroyed, this statement is made: "Out of five hundred and fifty-two stomachs inspected by the Biological Survey, forty-seven contained noxious insects, fifty held beneficial insects, and thirty-one contained insects of little or no importance."

There is a wide-spread feeling that the country would be better off if the English Sparrow had never been brought here. This sentiment 
against this bird, whether justified or not, has arisen because of the annoyance it gives to gardeners and fruit-growers; its tendency to destroy the nests of small native birds and thus drive them out of our towns; the loss caused by fires due to the nests placed about buildings catching

\section{Treatment as} a Pest sparks; its uncleanly habits spoiling sculptures on the façades of buildings; its noisy chatter about the house and yard where once the songs of other birds were heard, to say nothing of the petulant calling and fighting in the early morning heard about bed-room windows where late risers are taking their "beauty sleeps."

Resentment against the bird is reflected in the laws of our country, for in no state in the Union is the English Sparrow protected by statute. Every little while there are discussions in the public press about starting "Sparrow-wars" with a view to exterminating these birds. Now and then we hear of some community's efforts looking to this end. Such attempts, however, have virtually been futile, as the English Sparrow can take care of itself so successfully that only by continuous warfare against it, year after year, can its numbers be kept down.

Sometimes the experiment is made of offering a bounty on the heads of Sparrows. One objection to this procedure is that inexperienced persons, who are not able to distinguish between the English Sparrow and one or another of our native sparrows, immediately become active in such a campaign, and our native birds suffer as a result. An agent of this Association recently visited a western town where a bounty was being

\section{Methods}

of Suppression paid on dead English Sparrows. This agent examined the dead birds brought in during three days, and found that only one out of every eleven birds brought in were English Sparrows; the others were all useful native birds.

"What shall we do with the English Sparrow?" is a question which this Association is probably asked once a day on an average throughout the year. I confess my inability to answer this question. The Department of Agriculture at Washington has attempted to answer it by issuing bulletins advising people to poison and trap the birds. Whether this course is wise it may at least be said that all such attempts in a public way instantly produce strong opposition by many hundreds of men and women who, perhaps in lieu of more interesting bird-neighbors, regard with pleasure the presence of the English Sparrows, and often feed them upon their window-sills, or provide boxes for their accommodation.

\section{Classification and Distribution}

The English Sparrow belongs to the Order Passeres, Family Fringillide, and Genus Passer. Its scientific name is Passer domesticus. Originally a native of Western Europe, its range is now nearly cosmopolitan, wherever civilization offers it a chance to get a living in its accustomed way.

This and other Educational Leaflets are for sale, at 5 cents each, by the National Association of Audubon Societies, 1974 Broadway, New York City. Lists given on request. 


\section{THE SAGE GROUSE}

By T. GILBERT PEARSON

\section{The National Association of Audubon Societies}

Educational Leaflet No. 91

On a beautiful July evening our little party left the open waters of Lower Klamath Lake and slowly made its way up a combined creek and canal to Laird's Landing. At the little wharf the Audubon patrol-boat "Grebe" came to rest, and we stepped out to find before us the ranchbuildings of a stock-raiser lying in a semicircle of ragged desert hills that rose in uneven terraces to the distant horizon. A Western Meadowlark was singing in the yard and numerous Mourning Doves, the most ubiquitous birds in North America, were flying about. In the one small cluster of trees within sight Bullock's Orioles were nesting. Snipe and Phalaropes were brooding their eggs in the neighboring marsh, and a

Birds of the Sagebrush Western Horned Owl had only the night before moved her young from the big barn to the trees where the Orioles hammocknest swung.

These evidences of bird-life were noted within a few minutes after landing, but we had come in quest of something else-we sought a certain bird which the writer had never seen. There were plenty in the neighborhood we were told, and to find them we need only walk out on the sage-clad hills. The country had once been an interminable jumble of lava-beds disgorged from a heated and groaning earth. On every hand lay blocks of black volcanic rock, but the rain and frost of centuries had worn away the igneous mass, and made the soil that now furnished a scanty foot-hold for the sage. Over these silent wastes we walked. Twice we were saluted by the song of the Sage Thrasher, and thrice the trilling, canary-like notes of the Brewer's Sparrow were borne to our ears.

Suddenly, only a few feet distant a large bird burst from cover and went rushing away through the air at a good rate. To my startled gaze it seemed almost as large as a Turkey, although probably it weighed not more than four pounds. Its flight was distinctive. Turning its body

\section{The Sage-cock's Flight} to the left it gave four hasty wing-beats, then sailed on an even keel. only to turn to the right in another moment and repeat the performance.

Thus alternately sailing and flying, turning its body first to one side and then to the other, it pursued its course for perhaps a third of a mile and dropped again among the sagebrush. We had found the object we sought, the great Sage Grouse of the desert plains, the largest Grouse in the world save the Capercaillie of Europe. From bill-tip to tail-tip a grown male measures two and one-half feet, and the expanse of its wings is a yard or more. 
This was near the northern boundary of California, and at almost the westernmost limit of the bird's range.

Throughout all this vast region this feathered monarch of the plains was at one time abundant. Formerly it was not extensively shot for the reason that antelope, deer. and other larger game were usually to be met with. With the passing of the big game and the introduction of breech-loading guns a sad change has come over the fortunes of the Sage

Learning by Experience

Hen. In some remote corners of the West, where hunters rarely penetrate, these naturally trusting birds are so tame at times that one may knock them over with a stick. As a general thing, however, they have learned a proper dread of their human enemies.

This Grouse feeds very largely on the leaves of the sagebrush and its flesh is at times strongly permeated with the odor of this plant. Hence experienced westerners seldom shoot the old birds, for their flesh is tough and strong, and unless prepared by a master cook are usually regarded as totally unfit for food. Irvin Cobb, after such an experience, named the bird "The Battle Hen of the Republic." Young birds of the year that have fed largely on grasshoppers and other insects are regarded as being a choice food, and are esteemed as highly as the Ruffed Grouse or Bob-White. In the deserts around Burns, Oregon, I found the rangers quite able to distinguish between the old and young when the birds rose from the ground. That the young are quite as good as any game-bird in the land was proved to me by the delicious repast set before me by some of the good people of that arid country.

The Sage Grouse are entirely terrestrial. Living in regions where trees are rare they have never acquired the habit of alighting on a limb. Experienced gunners speak with admiration of the birds' ability to hide on the ground where there is extremely little cover, the only possible protection being the low growth of scattered sagebrush.

Observers have long noted that the feathers on the breast of the male Sage Grouse are often found in a worn and frayed condition, which would seem to indicate that this portion of the plumage for some reason

Worn Plumage Explained receives much rougher treatment than elsewhere on the body. An explanation of this, and also some interesting notes on the birds' behavior during the breeding season, was published some years ago in The Auk by Mr. Frank Bond, who, while living in the West, had many opportunities to observe the activities of this interesting bird.

"The peculiar feathers of the breast of the Sage Cock," he writes, "are more or less faithfully described by every ornithologist who has published a sketch of the bird; but as yet I have seen no explanation of the cause of the wearing away of the barbs and even shafts of the feathers of the lower neck. These feathers are worn away during that period of sexual excitement which causes many birds to develop odd and eccentric habits until the nuptial season is passed. The Sage Cock 


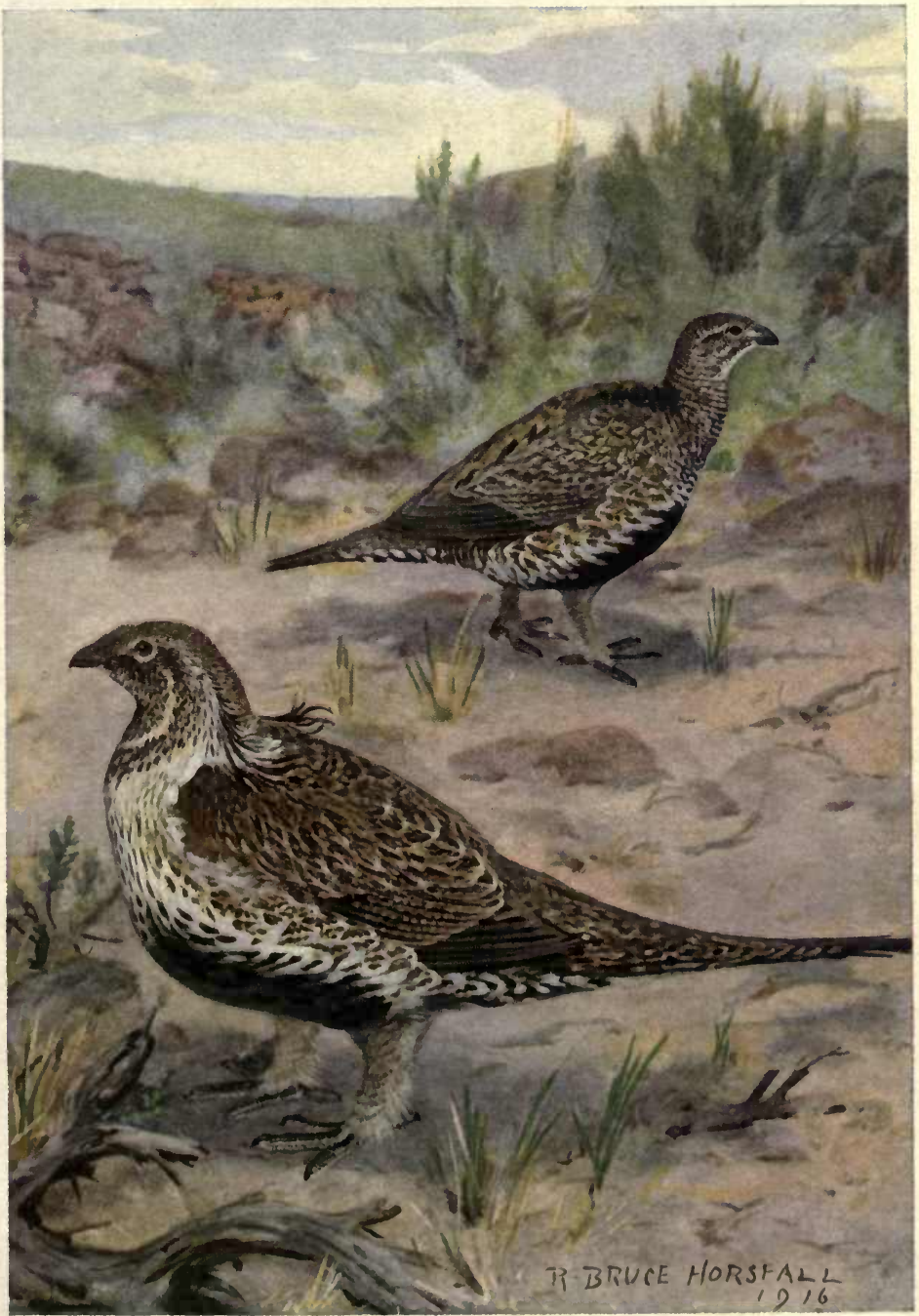

SAGE GROUSE

Order-Galline

Genus-Centrocercus
Family-Tetraonide

Species-URophasianus 

is unable to produce the musical booming sound of the Prairie Chicken, the forcible expulsion of the air from the sacks producing an inconsequential chuckling noise only; nevertheless the bird offers reasonable entertainment to any individual who will rise early and stroll out into the sagebrush a hundred yards from the camp-fire.

"During the months of April and May the Sage Cocks are usually found in small flocks of a half dozen or more, stalking about with tails erect and spread after the manner of the strutting Turkey-cock, but I have never seen the Grouse dragging their wings upon the ground, Turkey fashion, and in the manner described by Dr. Newberry in the quotation from this author found on page 406 of Dr. Coues's 'Birds of

'Best Foot Foremost' the Northwest;' nor have I ever found a wing of a Sage Cock, in this or any other season, which exhibited the slightest wearing away of the primaries.

"Instead of dragging its wings upon the ground the excited Sage Cock will enormously inflate the air-sacs of the neck until the whole neck and breast is balloon-like in appearance, then, stooping forward, almost the entire weight of the body is thrown upon the distended portion and the bird slides along on the bare ground or short grass for some distance, the performance being concluded by the expulsion of the air from the sacks with a variety of chuckling. cackling or rumbling sounds. The performance is continued probably daily, during the pairing and nesting season, and of course the feathers are worn away by the constant friction."

Mr. E. S. Cameron, who has studied the habits of the Sage Grouse in Montana, makes further comments on the peculiar antics of these birds when in spring the mating instinct becomes strongly developed. In part he says:

"During the first half of April the males repair to a regular 'playground,' but it is a difficult matter to observe their love-antics on account of the encompassing sage. However, on April 7, 1896, my wife and I happened to ride close upon a number of old cocks, near our ranch, which were engaged with their play in a small open space. They never fought nor threatened each other, but strutted or paraded before some hens concealed in the sage-bushes, and were entirely occupied with a most grotesque rivalry. By ruffling up all their feathers, spreading their tails, and dragging their wings along the ground, they looked much

Nuptial

Display larger than they really were, while they produced a rattling sound with their quills after the manner of Turkey-cocks and Peafowl. At the same time they continuously uttered a kind of whistling challenge, and, distending their necks by means of their air-sacs, erected an enormous white ruff. As the playground was small the eight or nine cocks upon it were in imminent danger of a collision, but for the ten minutes that we watched them this did not take place, nor were there any moments of ecstatic 
oblivion for which some game-birds are famous. As will be seen from the above their courtship is rather a display than a 'play' thus differing from the performance of the Sharp-tailed Grouse, which is described under that bird."

Like all Grouse this species has its nest on the ground. This consists of a slight hollow, usually under the shelter of a sage-bush, but sometimes it may be found under a bunch of high grass in the neighborhood of some stream or small body of water. Occasionally one may come across a nest containing a slight lining of grass-blades, or of sage-

Nest and

Eggs

brush, twigs, or leaves, but more often there is no lining of any character. In number the eggs range from six to nine. They are olive-buff, or greenish brown in color, and are prettily marked with round spots of dark brown.

As already intimated the food of the Sage Hen, to a considerable extent, is composed of the leaves of the sagebrush, but the birds also eat other leaves, tender plants, and even blossoms. Grasshoppers, ants, and such other insects as are available are also consumed. I have never heard a farmer complain of a Sage Grouse injuring his growing crops except in rare instances.

The time has arrived in the history of the Sage Grouse when it is riecessary that more restrictive measures should be enacted and enforced for its protection if the bird is to be spared from the fate of the antelope. which at one time existed in great numbers over a large part of the range in which the Sage Grouse still persists. It is true that laws have been enacted for their protection, but these are not adequate, as

\section{Protection}

Needed

in Idaho, for instance the birds may be shot for

three and a half months, and in Nevada four and

a half months each year. This is entirely too long a season, especially when we take into consideration that the baglimit, or in other words, the number of birds that may legally be killed in a day, in Nevada is ten and in Idaho is twelve.

The State of Washington has already taken steps in the right direction by permitting an open season of only fifteen days (October 15 to November 1), and allowing a bag-limit of only five birds daily.

\section{Classification and Distribution}

The Sage Grouse belongs to the Order Gallina, and the Family Tetraonida. Its scientific name is Centrocercus urophasianus. Its range corresponds very nearly to that portion of North America where the sagebrush grows. It is found in southern British Columbia, southern Alberta, and thence southward through eastern Oregon, Montana, Wyoming. Idaho, Colorado, Nevada, Utah and eastern California. The southern limit of its range is reached when the desert-growth turns from sagebrush to creosote in northern Arizona and New Mexico. It is not migratory.

This and other Educational Leaflets are for sale, at 5 cents each, by the National Association of Audubon Societies, 1974 Broadway, New York City. Lists given on request. 


\section{WHITE-THROATED SPARROW}

By T. GILBERT PEARSON

\section{The National Association of Audubon Societies}

Educational Leaflet No. 92

It is in autumn, when the hills take on their dresses of red and gold and the fields stretch away brown and deserted to the blue haze hanging along the horizon, that I go in quest of the White-throated Sparrows. They are not to be found in the deep woods, nor often on the open meadows, but it is in the hedge-rows among the briars of the old fence-corners, or in the thickets on the edge of the forest that one will discover them. When you find one Whitethroat you are pretty sure to find several others. Very often they are with Juncos, and sometimes a few Song

Haunts Sparrows are found feeding in their company. There are usually at least a dozen in a flock, and sometimes fifty or a hundred birds will be found together, at least half of which are Whitethroats.

This bird was a favorite with Audubon, and his account of its behavior in the autumn days gives one a splendid idea of the Whitethroat's manner of life at this season:

"How it comes and how it departs are quite unknown to me. I can only say that, all of a sudden, the edges of the fields, bordering on creeks or swampy places, and overgrown with different species of vines, sumac bushes, briers, and the taller kinds of grasses, appear covered with these birds. They form groups, sometimes containing thirty to fifty individuals, and live together in harmony. They are constantly moving up and down among these recesses, with frequent jerkings of the tail, and uttering a note common to the tribe. From the hedges and thickets they issue one by one, in quick succession, and ramble to the distance of eight or ten yards, hopping and scratching, in quest of small seeds, and preserving the utmost silence. Whenever the least noise is heard,

\section{Audubon's}

Experience or alarm given, and frequently, as I thought, without any alarm at all, they all fly back to their covert, pushing directly into the thickest part of it.

"A moment elapses, when they become reassured, and, ascending to the highest branches and twigs, open a little concert, which. although of short duration, is extremely sweet. There is much plaintive softness in their note, which I wish, kind reader, I could describe to you; but this is impossible, although it is yet ringing in my ear, as if I were in those very fields where I have so often listened to it with delight.

"No sooner is their music over than they return to the field, and thus continue alternately sallying forth and retreating during the greater part of the day. At the approach of night they utter a sharper and shriller 
note, consisting of a single twit, repeated in smart succession by the whole group, and continuing until the first hooting of some owl frightens them into silence. Yet, often during fine nights I have heard the little creatures emit here and there a twit, as if to assure each other that all's well."

The food-supply of some birds consists entirely of one special kind of article. For example, we can hardly imagine a Cormorant, Pelican, Osprey or Kingfisher engaged in consuming any food other than fish. Swallows and Swifts eat insects that they capture while in full flight. To secure such a diet it is therefore necessary for them to travel long distances twice a year to reach lands where the insectGeneral Diet life they desire may be obtained. With Sparrows, however, we find that quite a different condition exists. They are not fitted for capturing fish, as does the Pelican or the Osprey, but they do eat almost any kind of food that is available.

In the fall of the year White-throated Sparrows consume many berries, which they pick off the vines and berry-producing trees. They collect also the seeds of those berries that, dried or decayed, fall to the ground. Not long ago I watched for a time a flock of fourteen of these Sparrows feeding on the red berries of a little tree growing in a park. I have not been able to learn the name of the tree, but the berries it

Fond of Berries produces are evidently very choice from the standpoint of the birds. Some of the Sparrows were busily employed in picking off and eating the fruit. Others, perhaps early comers, were already satisfied, and in a bunchy, ruffled-up kind of attitude, sat very still and appeared to take no note of the sound of the banquet going on all about them. It was only when a vagrant cat appeared on the hillside near by that these drowsy fellows exhibited signs of returning animation.

In collecting weed-seeds the birds hop about among the vines or tall weeds and carefully search through the debris on the ground. When the earth is strewn with fallen leaves, and these are dry, the rattling, rustling noise of a flock of feeding Whitethroats may lead one to think a Grouse family is advancing along the ground. Whitethroats fly up and alight on the sides of ragweeds, and, hanging there, fluttering, they pick at the seeds that have not yet dropped. I have seen slender, brittle weed-stalks break off in such circumstances and down would Destroy come weed-stalk, birdie and all. It may readily
Weeds be seen that these birds are valuable to the farmer who spends most of his summer trying with hoe and plow to keep the weeds from over-running his crops. For this reason laws for its protection have been passed in all the States where this Sparrow is found.

Among migratory birds the exclusive insect-eaters are, as a rule, among the first to leave their northern homes in autumn, while those that are more omnivorous in their feeding usually linger until the winter 


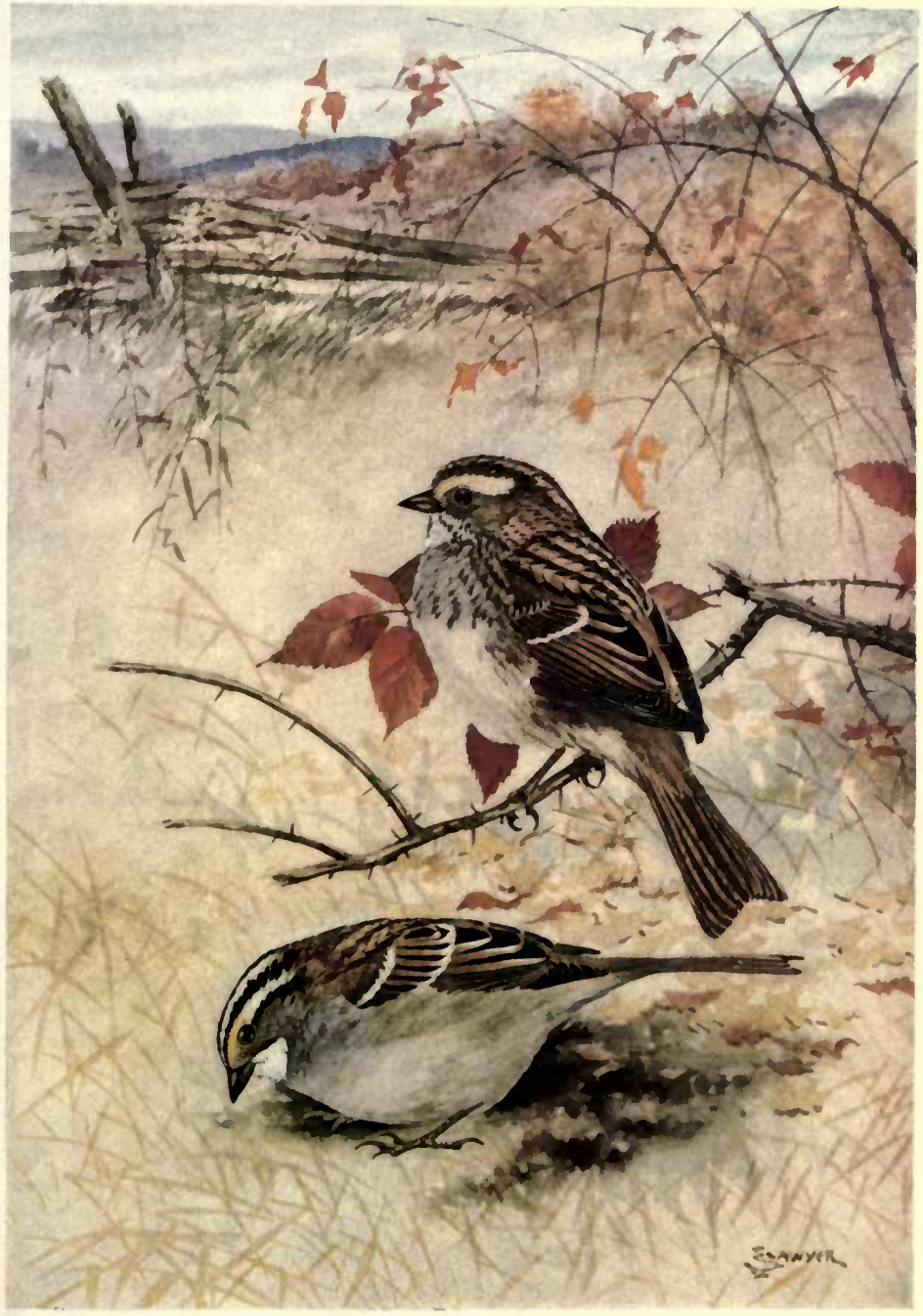

WHITE-THROATED SPARROW

Order-Pasarers

Genus-ZONOTRICHiA
Family-FRINOILLIDE

Species ALBICOLLIS

National Association of Audubon Socleties 

is fairly upon them. Many of the Whitethroats do not depart until November, and, in fact. numerous flocks remain all winter as far north as New Jersey and Ohio. Some, indeed, are often seen throughout the winter at places even north of this region. In suitable localities all over the South as far as the Gulf of Mexico they pass the colder months. Here they thrive and grow fat and sometimes are killed and eaten. Audubon describes at length the method employed by people in Louisiana to secure the birds in the early part of the last century. They were killed by blowing sharp sticks tipped with squirrel fur through a hollow reed; in short, these hunters used blow-guns much like those employed today by Indians in the jungles of South America and elsewhere. Today the laws of all the Eastern States protect the Whitethroat, and its enemies

\section{A Novel Weapon} are now mainly the Screech Owl, to a less extent the Sparrow and Sharpshinned Hawks, but most of all vagrant house-cats.

By the middle of November the majority of these Sparrows have departed from the latitude of New York, and will not be seen there again until March or early April. From then until the dogwoods are in full flower these birds are about, and may be seen if one will only take the time to tramp about the country until they are found. They begin to arrive in Canada early in May and soon all over the eastern part of the Dominion. where forests or woodland abound, the Whitethroats are to be seen. In the summer they occur as far west as Alberta, and are said to be very common in the central part of that Province.

\section{The Sing-Away Bird.}

Have you ever heard of the Sing-away Bird,

That sings where the Runaway River

Runs down with its rills from the bald-headed hills

That stand in the sunshine and shiver?

"Oh, sing! sing-away! sing-away!"

How the pines and the birches are stirred

By the trill of the Sing-away Bird!

'T was a White-throated Sparrow, that sped a light arrow

Of song from his musical quiver.

And it pierced with its spell every valley and deli

On the banks of the Runaway River.

"Oh, sing! sing-away! sing-away!"

The song of the wild singer had

The sound of a soul that is glad.

\section{- Lucy Larcom.}

Of all the many members of the Sparrow family found in North America no species is better known for its song than this one. In the evergreen forests of the North its clear, beautiful whistle is one of the most characteristic sounds of the region, and it strikes the ear with a 
freshness that is truly delightful. Many writers have tried to interpret its song and tell us in English what the bird is saying when it sits upon the pine-top and whistles away for half an hour at a time. Mr. Stansell, of Alberta, for example, tells us that the call to his mind strongly suggests the words "Oh see me me me me me." A very common rendering of its song is given as "Old Sam Peabody, Peabody, Peabody." There are many variations of this last translation,

The "Peabody"

Song in all of which the word "Peabody" is prominent; hence long ago the custom arose of calling it the Peabody Bird. A Nova Scotian variant is "Joe Kennedy Bird."

On the other hand, probably more Canadians know it as the "Sweet-Canada Bird," for they are thoroughly convinced that when the Sparrow sings it says "Swe-e-et Can-a-da, Can-a-da, Can-a-da." William Hamilton Gibson relates the incident of a perplexed farmer named Peverly, who did not know what to plant until he heard a Whitethroat sing, "Sow wheat, Pev-er-ly, Pev-er-ly, Pev-er-ly."

It is rather easy to whistle an imitation of the Whitethroat's notes, and so much curiosity does the bird possess that often it will come from a distance at the call, and chirp and look and crane its neck with the liveliest interest. Comparatively few birds that will do this. The BobWhite will come if called by an expert, and in spring or summer almost anyone can gather a number of small birds around them in the woods by merely sucking the back of the hand, thus making a squeaking noise. In this case the birds show evidence of alarm and concern, for such a sound is a fair imitation of a baby bird in distress.

The White-throated Sparrow is quite a handsome bird. With the exception of the Fox Sparrow bird-students would perhaps vote it the

A Handsome handsomest species of the Eastern States. It is six

Sparrow and three-quarters inches long, which is one and a quarter inches longer than the Chipping Sparrow, but the Chipping Sparrow is much more slender.

The nest is usually built on or near the ground. It is made of grasses, grape-vine stems and other substances of a similar character. The lining is usually of fine grasses, although at times feathers, deerhair, or rabbit-fur is used as a soft bed for the eggs. These range from four to five in number, and their pale green ground-color is thickly marbled with various shades of chocolate and brown.

\section{Classification and Distribution}

The White-throated Sparrow belongs to the Order Passeres, and to the Family Fringillida. Its scientific name is Zonotrichia albicollis. It ranges throughout eastern North America, breeding from the region of the Great Lakes and northern New England northward to northern Quebec and the southern borders of Alaska; and wintering from central Missouri, the Ohio Valley and southern New England southward to Florida and northeastern Mexico.

This and other Educational Leaflets are for sale, at 5 cents each, by the National Association of Audubon Societies, 1974 Broadway, New York City. Lists given on request. 


\section{THE PHCEBE}

\section{By T. GILBERT PEARSON}

\section{The National Association of Audubon Societies Educational Leaflet No. 93}

There is a little camp in the woods on the New York side of Lake Champlain where three children and their parents go every summer. It is a good place to see birds. In fact, the children are awakened every

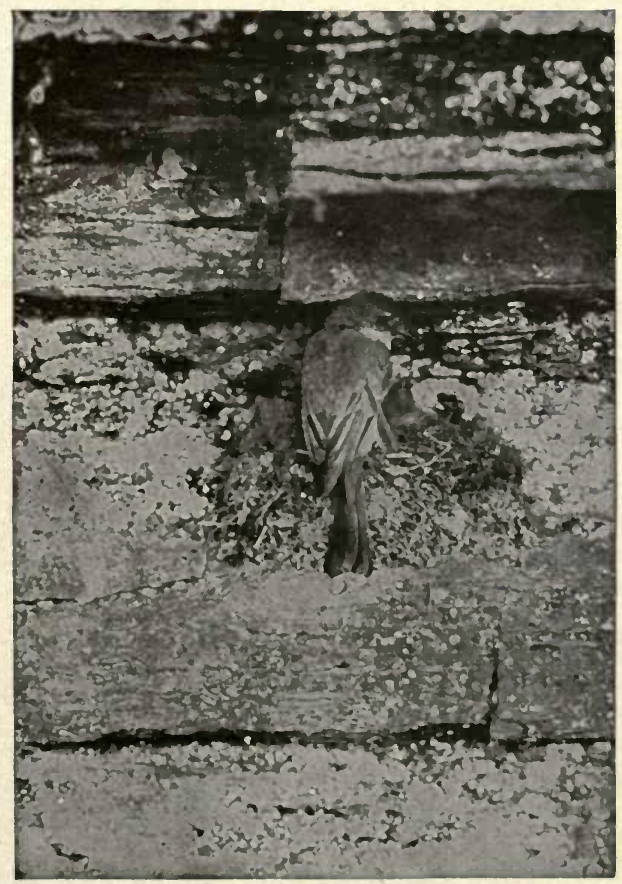

PHCEBE AT NEST ON STONB LEDGE

morning by birds singing in the trees all around them. There are Redstarts and Chestnut-sided Warblers about every day. Near by the Ovenbird calls "teacher, teacher, teacher," until one begins to wonder what has become of that dear instructor. Sometimes the old Grouse follows her young through the thicket and under the veranda. In the evening it 
is pleasant to sit on the porch and listen to the Veeries. Sometimes a dozen sing until the night shuts in upon them.

Of all the birds, however, that visit "Bird Nest Cottage" the Phœbe is the most trustful. She and her mate may be seen at almost any time, either on the veranda-railing or on some bare limb of a tree near by.

When the family arrives on the fifteenth of June, the children, after one look in the camp, all rush out to find the Phœebe's nest, and for several years they have never been disappointed.

Three seasons this bird built under the veranda, placing the nest on cross-timbers. Last summer the nest was made on the top of a windowfacing just under the low-hanging eaves. This place would be a very insecure foundation for a nest as large as that built by the Phobe, as the projection is less than an inch from the side of the wall, if the nest were made of sticks and straw, but the Phœbe builds her cradle cliefly of mud, so she can plaster it to the wall almost anywhere that there is just a little support. Moss is usually employed in addition to the mud.

Four white eggs are laid. These are rarely adorned with a few brown spots. The children, however, have never been able to discover whether this particular Phœbe lays pure white eggs or whether they are spotted. The reason for this is that the eggs are always hatched by the middle of June.

- All day long the plaintive pewit phobe of the parent birds may be heard, and every few minutes one of them brings food to the nest.

One night we took an electric torch and climbed down the rocks under the veranda to see what the Phøe family was doing. There, sprawled all over the top of the nest, were four well-grown youngsters-the parents were nowhere in sight. Had the little ones At Night been hatched only a few days we should probably have found the mother at home, but now there was no need for her presence to keep the babies warm, for they were not only nearly as large as their mother, but well covered with feathers. The night was warm, so it was more comfortable for everybody to leave the young ones by themselves, while the mother roosted in a tree near by. I suppose it was a great relief to her to be able to get an unbroken night's rest once in a while after a hard day's work gathering food.

There are other camps in the neighborhood, and probably every third one has its pair of Phœbes. Some of the people do not like to have the birds around, so I have heard that they tear the nests down, but at "Bird Nest Cottage" Phœbes are always welcome.

Phœbes build their nests in a great variety of places. Thus they are found on the joists of barns or other out-buildings; on the cross-pieces of verandas; under the eaves; in culverts, or on the sides of stone walls. Once I knew a Phœbe that built her nest on the side of a disused open well. The spot selected was about six feet below the level of the ground and was protected by a broken piece of a rotting curbing. Stone piers of country bridges are favorite places and the bird is widely known as "Bridge Pewee." 
Fi.

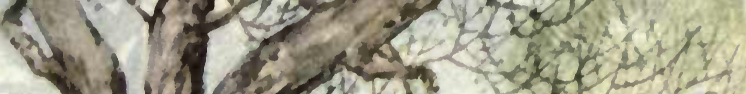

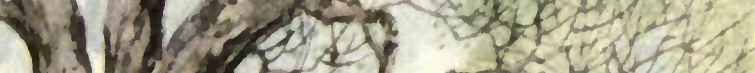
$1,-1$

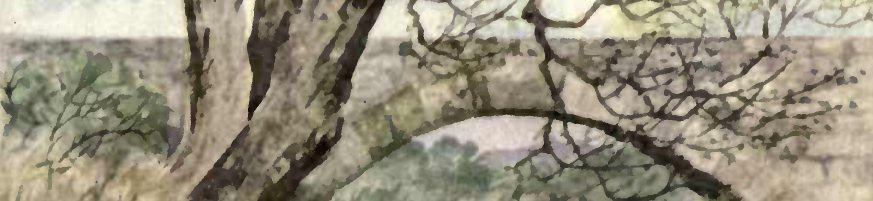
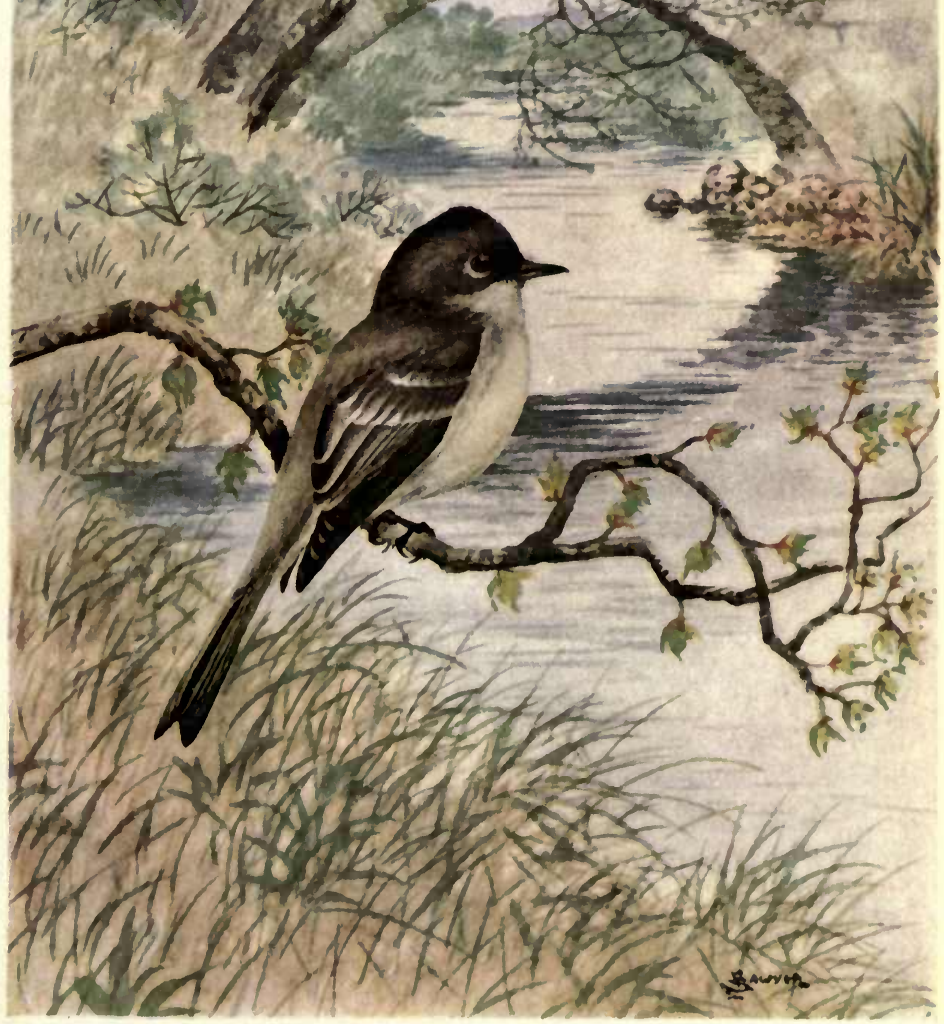

THE PHOEBE 

In BirD-Lore, some years ago, Mr. John Burroughs recounted an incident of a Phobe that suddenly found herself deprived of the one spot on the ledge of a rock where she had been building her nest for years, and which may have constituted the only place where she had ever had a nest. At this juncture he states:

"A new stone house had been built upon the rocks above me, with a piazza all around it, covered by a continuation of the main roof down the required distance. After much inspecting of this piazza the birds concluded to build a nest upon the plate beside one of the rafters. Now this plate was about thirty feet long and there were ten rafters notched upon it, and hence ten plates exactly alike. The bird selected the fourth rafter from the end nearest the woods, and began her nest upon the plate beside it. She was in a great hurry and worked 'on the jump,' so to speak. She got her mortar in the ditch near my cabin. One morning I watched her for some time. She made a trip every minute, carrying her load up a steep grade about one hundred yards. The male looked on and cheered her, but did not help. He perched upon a dead sunflowerstalk near the ditch, flirted his tail, and said, or seemed to say, 'Go it. Phobe, you are doing well; you are the wife for me.' Every trip the mother bird made he would accompany her a short distance and then return to his perch.

"As the nest-building seemed unusually prolonged, I went up one morning to the new house to see how matters were progressing. Instead of one nest I found five in process of construction. Some had only the foundation laid, others were an inch or two high, and one was threefourths finished. I sat down to see what it all meant. Presently the eager builder came with her beak loaded and dropped down upon one of the nest-foundations. She seemed to hesitate a moment, as if she had a suspicion that something was wrong, and then put down her material and flew quickly away. The next time she struck the nearly finished nest and put down her load without hesitating. I watched her for half an hour and soon saw how it was with her-why she scattered so. I concluded she was misled by the sameness of the rafters-they were all alike, and whichever one she chanced to hit in her hurry, there she deposited her mortar. She had been used to a ledge where there was but one building-site; here there were half a dozen or more, with no perceptible difference be-

\section{The Confused Mother}

tween them. So I hit upon a plan to concentrate her-I put blocks of wood or stones in all the nests but one and watched the result. When now she came upon these strange obstacles she would hover about for a moment until she discovered the largest and unincumbered nest, when she would alight upon it and leave her load. She then soon took the hint, finished the one nest, laid her eggs, and went forward with the incubation."

John James Audubon, the great naturalist, tells us in one of his books of the movement of a pair of these birds about their nest. He hid 


\section{The Phœbe}

in a cave near the nest while the birds went about their daily affairs. He says:

"The female one day spent tine greater part of the time in her nest; she frequently changed her position; her mate exhibited much uneasiness, he would alight by her sometimes, sit by her side for a moment and sucdenly flying out would return with an insect, which she took from his bill with apparent gratification. About three o'clock in the afternoon, I saw the uneasiness of the female increase; the male showed an unusual appearance of despondence, when, of a sudden, the female rose to her feet, looked sidewise under her, and flying out, followed by her attentive consort, left the cave, rose high in the air, performing evolutions more curious to me than any I had seen before. They flew about over the water, the female leading her mate, as it were, through her own meanderings. Leaving the Pewees to their avocations, I peeped into their nest, and saw there their first egg, so white and so transparent that to me the sight was more pleasant than if I had met with a diamond of the same size."

Very often the Phœbe rears two broods of young in a year. In such cases the first nest is rarely used a second time. Their nests are often infested with insects that must render the lives of the young very uncomfortable; in fact they are sometimes killed by the attacks of these parasites.

Few birds are greater insect-eaters. One need only watch a Phœbe a few minutes to become convinced of this fact. True Flycatcher that

Insect

Food he is, the bird lies in wait for his prey. His watchtower is some dead limb or stake. Here he sits, frequently jerking his tail nervously and calling in his petulent, impatient way until some insect comes flying along. Then out he darts, seizes his prey in his beak, and returns to his perch.

Phœbes eat many beetles, weevils, grasshoppers, and wasps, as well as flies that bite and sting cattle. A few seeds are eaten and the bird eats also an occasional cherry, elderberry, or other wild fruit. It is among the first birds to arrive in spring, and is the only Flycatcher in the United States that spends the winter north of the frost-line. It may be seen in Florida, Louisiana, and other southern states in the winter.

\section{Classification and Distribution}

The Phobe belongs to the Order Passeres, the family Tyrannida (Tyrant Flycatchers), and the genus Sayornis. Its scientific name is Sayornis phoebe. It breeds throughout all the United States and southern Canada, east of the dry plains as far north as New Brunswick, northern Manitoba and northern Alberta, and as far southwest as eastern New Mexico; and winters in the Gulf States and southward to southern Mexico.

This and other Educational Leaflets are for sale, at 5 cents each, by the National Association of Audubon Societies, 1974 Broadway, New York City. Lists given on request. 


\section{PILEATED WOODPECKER}

By T. GILBERT PEARSON

\section{The National Association of Audubon Societies Educational Leaflet No. 94}

While lying abed late one morning in camp listening to the lusty shouts of a Florida Wren, I became aware of a muffled knocking sound often repeated. It was the time of day when a field naturalist should be up and abroad, but we had gone into camp late the evening before after a hard day's trip, so I was trying to get a little beauty sleep while the guide was away on the lake seeking fish for breakfast. But the Wren would not permit slumber, so with mixed feelings of admiration and annoyance, I lay and listened to its wild expressions of merriment. The mysterious pounding finally caused me to get up and go out of the tent to discover its source. In a little while I found, about sixty yards away, a tall dead tree, old and greatly decayed. Perhaps fifty feet from the

The

Nest ground was a fresh round hole, while numerous fragments of wood were scattered on the carpet of dry forest leaves beneath. It was clear that the pounding was going on inside this tree and at some distance from the ground.

Bringing an axe from the camp I gave the tree several vigorous strokes. Soon there emerged from the entrance-hole a Pileated Woodpecker. After bounding away a few yards it returned and alighted just above its nesting-hole. It surveyed me in a startled nanner for a few seconds and then flew to a nearby tree. Its shouts soon brought its mate, but the wary birds did not tarry long. In a few minutes the forest had swallowed them. For five lays we lay in camp at this spot, and while we rarely saw the Pileated Woodpeckers it was only necessary to remain in the tent a short time at almost any period of the day in order to hear again that muffled knocking sound, made by one of the birds as it chiseled away at its work.

The birds were not sufficiently frightened or annoyed by our presence to desert the nest they probably were building, but it was evident that they wished to take no chances by allowing themselves to be seen.

There possibly may have been eggs in the nest at the time, for these Woodpeckers are known to dig away at the walls of their nesting-cavity with their bills after the eggs have been laid.

With what fortunes the birds met in their attempt to rear a brood that year I did not learn, but doubtless they had a successful season. Eight months later, when passing through the same territory, I visited the spot and found that the old tree had fallen. Cutting away the wood I discovered that the cavity made by the Woodpecker had extended down- 
ward for a little more than three feet, turning slightly to the right as it descended. Why the hole had not been dug straight downward I could not discover, as there was no knot or other indication of especially hard wood that would seem to turn the builders aside. Nevertheless, the bottom of the hole, where, on a layer of fine chips the eggs and young must have rested, was at least four inches to the right of the entrance.

This nest was found in one of the innumerable hamnocks which surround many of the lakes in central Florida. Here the heavy growths of oak, magnolia, hickory, and gum, make an ideal home for these timid Woodpeckers. The birds are still abundant in suitable regions of that state, but one should go to the primeval forests to find them, for they do not like woodlands that have been cut over, and it is very rare to see one in the open pine-barrens of the sandy country.

Next to the giant Ivory-billed, which is now almost extinct in the United States, the Pileated is the largest of the Woodpecker family found in this country. In order to get a somewhat accurate impression of its size one may think of it in comparison a Crow as to a Crow. From tip of bill to tip of tail the Common Crow is about eighteen inches, and when the wings are spread to their greatest extent the distance from tip to tip is about twenty-seven inches. The same measurements for the Woodpecker under discussion are seventeen inches in length and twenty-seven and a half inches across when the wings are expanded.

There is, however, much individual variation in the size of both birds. For example, the Woodpecker ranges in length from fifteen inches to nineteen inches, and the expanse of wings varies in different individual birds from twenty-five to thirty inches, so it is a perfectly truthful statement to say that the Pileated Woodpecker is as large as a Crow.

The eggs of this species, like those of all other Woodpeckers, are glossy white. They range in number from four to six, and in size measure about one and a quarter inches in length and a little less than an inch in width. The period of incubation is eighteen days. The young are hatched naked and are extremely helpless. They do not leave the nesting-cavity until the wing-quills are well grown and the birds are quite able to fly. The parents take turns incubating the eggs and it is said that if the one on the nest desires to leave, it will call its mate and remain in the hole until the other comes.

The food of the Pileated Woodpecker is composed largely of insect life. It is very fond of grubs, wood-boring beetles and ants, especially those species that make their homes in dead wood.

\section{The}

Woodcutter To procure this food the Woodpecker has developed remarkable skill as a woodcutter. It will attack a dead tree or $\log$ and in half an hour will leave a pile of chips of which a less ardent worker might well be proud. Often fragments of wood as large as one's hand may be seen where the bird has been at work, and I once measured a combination chip and splinter more than fourteen inches in length. While engaged in this carpenter work, 


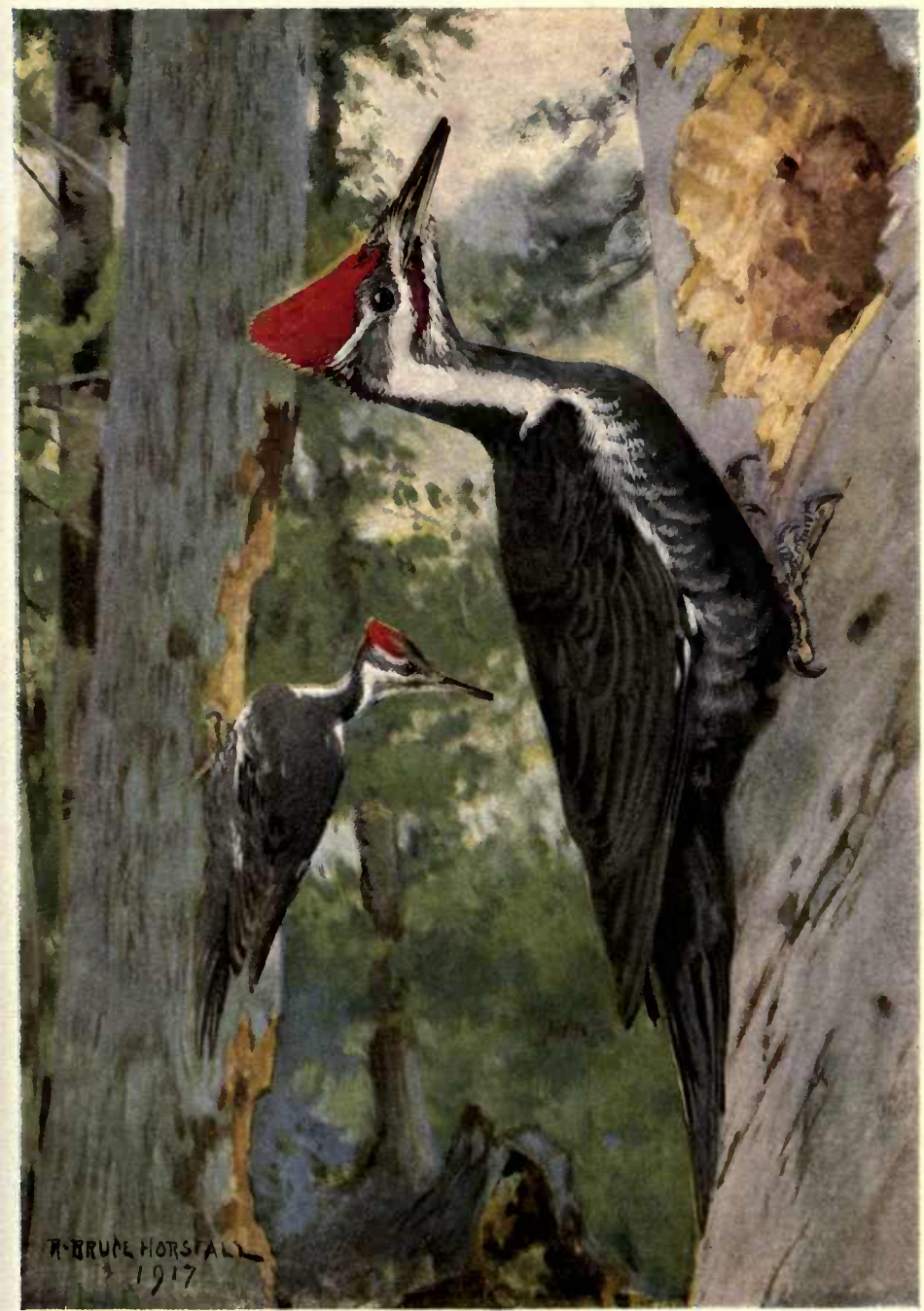

PILEATED WOODPECKER 

the Pileated Woodpecker is not always the shy bird we sometimes think it to be. One frequently may approach in the open woods to within a few rods of a feeding bird, and often when startled its flight may be of short duration. In some of the southern towns where heavy forests are adjacent this species will sometimes come into the groves about dwellings.

While a student at the University of North Carolina, I remember seeing three on the University campus at one time. Three pairs of the birds constantly inhabited the college woods, a tract of perhaps one hundred acres, which adjoined the campus. Although the nests are often built a considerable distance from the ground, I have found them in Guilford County, North Carolina, at a height not greater than twelve feet, but this was probably exceptional.

Mr. Arthur T. Wayne, of Mt. Pleasant, South Carolina, who has spent much time studying the habits of this bird, in his Birds of South Carolina, says:

"This species uses a certain hole, which it excavates in a living. black gum or a living sweet gum tree, in which to sleep, and it is so attached to it that I have known one of these birds to resort for years to the same hole to spend the night. This sleeping-hole is almost always excavated in a tree which is hollow from the base to within a foot of the first limb. Sometimes two holes are bored in the same tree, and if an attempt is made to catch the bird, it can escape by going through either of the holes or else make its exit at the base.

"If the season is a forward one the birds mate early in February, and towards the latter part of the month they begin to excavate their hole, which requires exactly a month for completion. During the month of March, 1904, I made observations on a pair which excavated their hole

\section{The Sleeping Place} in a dead pine On March 21, the opening was commenced by the female, who drilled a small hole, and by degrees enlarged it to the size of a silver dollar. The male assisted in the excavation, but the female did by far the larger part of the work. The size of the aperture was not increased until necessary to admit the shoulders of the bird. I visited these birds every day in order to note the progress of their work, and, being so accustomed to seeing me, they were utterly fearless and I could, at any time, approach within twenty feet without hindering the work, although the hole was only about thirty feet from the ground. This hole was completed on April 21, and the first egg was laid the following morning. As incubation commences upon the advent of the first egg, and as the eggs are not laid consecutively, I did not again examine the contents of the nest until April 26, when three eggs were found. Upon investigating the cavity on April 28 , and finding but three eggs, I concluded that the set was complete. In this case the excavation was made under a dead limb, and was about eighteen inches deep, being hollowed out more on one side than the other. This Woodpecker is so attached to the tree in which it has first made its nest that it continues to cling 
to it as long as it can find a suitable spot at which to excavate a new hole. It never uses the same hole a second time. I know of a pair of these birds which resorted to the same tree for four consecutive years, and each year they excavated a new hole.

"Another pair of these Woodpeckers bred in a gigantic dead pine for three years, and as an illustration that their large holes are in great demand by other birds, and even mammals, for breeding purposes, I will state that on April 16, 1903, there were three species breeding in the same tree, namely-Pileated Woodpecker, four eggs, at a height of 54 feet; Fox Squirrel, at 70 feet; and Sparrow Hawk, at approximately 90 feet from the ground-all living together in perfect harmony!

"If this bird is deprived of its first set of eggs, it at once excavates a new hole, and the length of time consumed in its construction is about twenty-five days."

The Pileated Woodpecker is one of the noisest tenants of the heavy forests and wooded swamps which it inhabits. Particularly is this true

A Noisy

Bird during the mating-season and after the young have left the nest. They have a long rolling cry which strongly suggests similar notes produced by the Flicker, except that they are louder and the intervals between the calls are slightly longer. At times they become extremely animated, and two or three will gather on the trunk of some tree or the larger limbs and engage in querulous, conversational, wick-y-up notes which again suggest the actions and calls of the Flicker.

In flight the bird does not proceed with undulating movements common to many Woodpeckers. The flight is more or less directed in a straight line. The white underparts and the large white blotches on the wings contrast strongly with the black back. The white wing-area shows so plainly that one may, often discover the bird flying at a distance by the heliostatic flashes of white.

Although, as already indicated, the food consists largely of an animal diet, the bird also is fond of certain forms of wild berries, and one presents an awkward and ungainly appearance as, in an uncertain and more or less laborious manner, it seeks to retain its perch and gather berries among the small twigs.

The Pileated Woodpecker is found over a wide range of North America. From southern Florida, middle Texas and California it is distributed in suitable localities as far north as British Columbia, central Quebec and Newfoundland.

Of recent years, ornithologists have regarded the species as being composed of two varieties, the Northern Pileated Woodpecker, embracing those individuals found along the Alleghany Mountains and northward throughout its Canadian range.

The bird has a variety of local names such as 'Cock-of-the-Woods,' and 'Log-Cock.' One of the most popular in the South is 'Good-God.'

This and other Educational Leaflets are for sale, at 5 cents each, by the National Association of Audubon Societies, 1974 Broadway, New York City. Lists given on request. 


\section{THE RAVEN}

By T. GILBERT PEARSON

\section{The National Association of Audubon Societies Educational Leaflet No. 95}

One July morning in company with Edward H. Forbush and William P. Wharton I landed on a small wooded island off the coast of Maine to visit a group of Herons said to be nesting there. Clambering up the rocky shore we proceeded with some difficulty through the thick underbrush of the evergreen forest until the heronry was reached. Here the trees were more scattering and the sun's rays breaking through were ripening the thousands of gooseberries that covered the canopy of the vines below. The main colony consisted of Black-crowned Night Herons. Approaching a tree where one of their nests was located I was surprised to find on the ground beneath the remains of four young birds about one-third grown. The flesh had been picked from the bones, but these were in no way broken, which precluded the possibility of the mischief having been done by a predatory animal, if indeed any such existed on the island. While we stood about discussing the matter, a cry, so wild and unusual rang through the damp woods that in an instant our attention was rivetted on the sound. Presently it was repeated and was quickly answered from two other directions.

At once we began a search, which soon resulted in finding that the calls emanated from a family of young Ravens now well grown, but still attended by their parents. The evidence that the Ravens had destroyed these young Herons was indeed scant. However, I believe all the members of the party, knowing something of the habits of these birds, still regard it as probable that it was the

Raven family that had raided the big stick nest in the evergreen trees. That something was feasting liberally on young Night Herons was quite plain for we found the fresh skeleton remains of at least a dozen of these birds, and a more thorough search of the colony might possibly have revealed others. This was on Bradbury Island in the year 1914.

A few days before this Ravens and a Raven's nest were found on Heron Island. On another occasion in company with Arthur H. Norton I was shown a large nest in an evergreen on No-Man's-Land Island which we were told had been occupied by a pair of Ravens every spring for many years. Ravens may be found also on Old Man, Black Horse, and in fact, on almost any of the uninhabited islands along the Maine coast.

In a little opening in the woods back of the Lake Hotel in Yellowstone Park, Wyoming, the garbage from the hotel tables is dumped. Thousands of tourists annually visit this dump to see the bears that come out to feed there in the evening. This garbage heap affords another interest to the bird-student, for gulls come up from the Lake 
and settle here in quest of food and not infrequently the hoarse croak of a Raven may be heard in the trees nearby. In fact, these great black birds come at irregular intervals all during the summer to pick up such scraps of food as were available.

In August, 1916, I saw a Raven feeding her three young with scraps picked up at a garbage heap back of a hotel on the western verge of the Glacier National Park in Montana. Although aware that she was being watched the old Raven would unhesitatingly come to the garbage heap, walk around until she found something that suited her fancy, and then fly with it to the trees fifty yards away. Apparently she would not suffer her young to leave the shelter-of the forest. The wide range of the croaks and cries made by the young was indeed astonishing.

Anyone who may chance to be in the mountains of western North Carolina and may desire to see Ravens can usually have their wish gratified by going out to some of the remote settlements and visiting the places where cattle are slaughtered for market. Sometimes as many as eight or ten Ravens gather around a slaughter pen and with evident impatience await their opportunity for a banquet.

From the above references it may be seen that the Raven has a wide range in the United States. In fact, there are few states north of South Carolina and Louisiana where it may not be seen, although its range is far more restricted than in former times. Many of the early writers speak of seeing Ravens in territories not now inhabited by them. For example, Thomas Lawson, Gentleman, who visited the coast country of Carolina in the year 1700, writes of seeing it there. Today Ravens rarely if ever occur east of the mountainous portions of the Carolinas.

Regarding the habits and manners of the Raven during the nesting season John James Audubon has given this description in his usual picturesque language.

"Their usual places of resort are the mountains, the abrupt banks of rivers, the rocky shores of lakes, and the cliffs of thinly-peopled or deserted islands. It is in such places that these birds must be watched and examined, before one can judge of their natural habits, as manifested amid their freedom from the dread of their most dan-

\section{Audubon's Account} gerous enemy, the lord of creation.

"There, through the clear and rarified atmosphere, the Raven spreads his glossy wings and tail, and, as he onward sails, rises higher and higher each bold sweep that he makes, as if conscious that the nearer he approaches the sun, the more splendent will become the tints of his plumage. Intent on convincing his mate of the fervour and constancy of his love, he now gently glides beneath her, floats in the buoyant air, or sails by her side. Would that I could describe to you, reader, the many musical inflections by means of which they hold converse during these amatory excursions! These sounds doubtless express their pure conjugal feelings, confirmed and rendered more intense by long years of happiness in each other's 


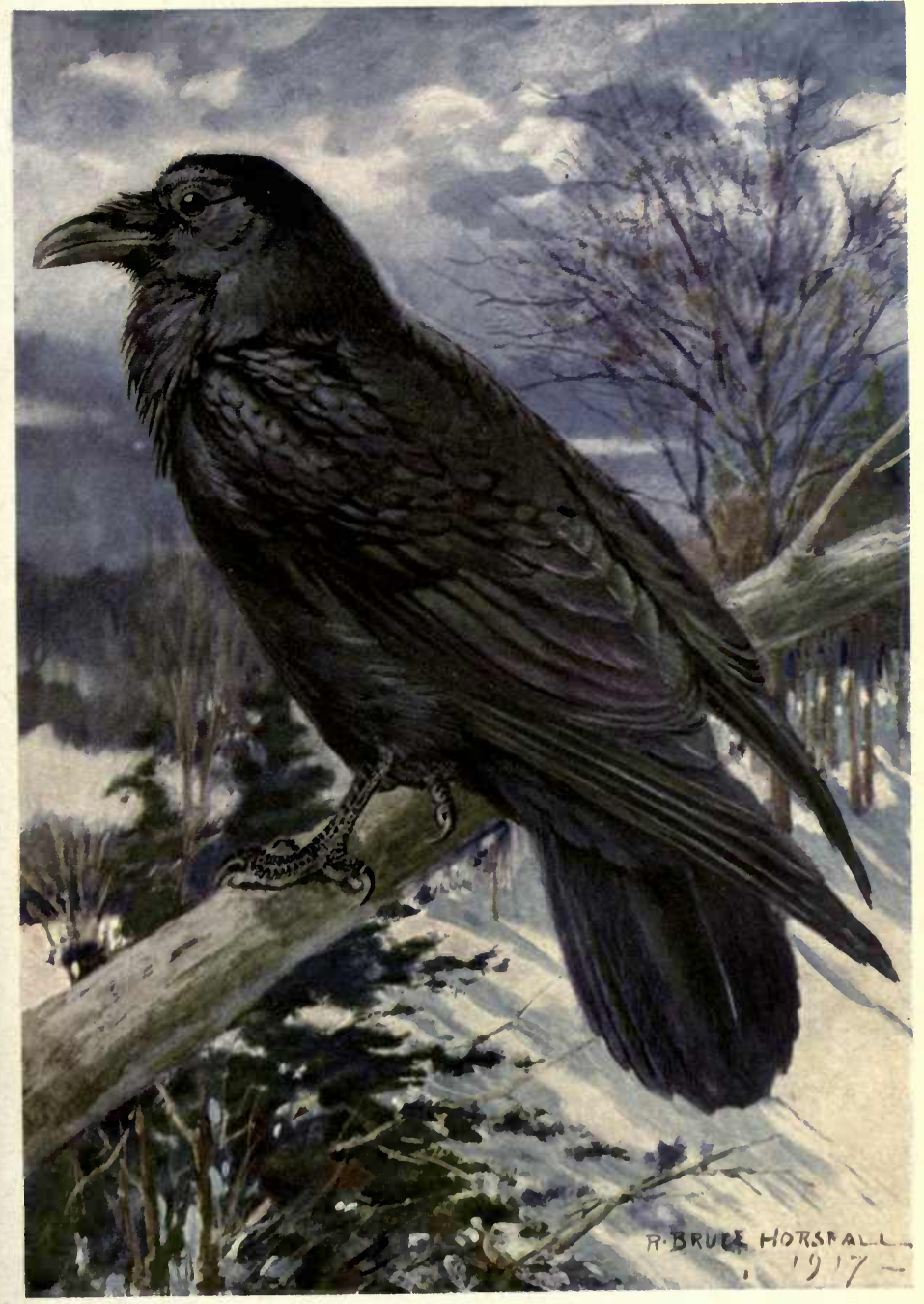

NORTHERN RAVEN

Order-PASSERzS

Genus-Corvus
Family-CORVIDE

Species-CORAX PRINCIPALIS 

society. In this manner they may recall the pleasing remembrance of their youthful days, recount the events of their life, and express the pleasure they enjoy.

"Now, their matins are over; the happy pair are seen to glide towards the earth in spiral lines; they alight on the boldest summit of a rock, so high that you can scarcely judge their actual size; they approach each other, their bills meet, and caresses are exchanged as tender as those of the gentle Turtle Dove. Far beneath, wave after wave dashes in foam against the impregnable sides of the rocky tower, the very aspect of which would be terrific to almost any other creatures than the sable pair, which for years have resorted to it, to rear the dearly-cherished fruits of their connubial love. Midway between them and the boiling waters, some shelving ledge conceals their eyrie.

"To it they now betake themselves, to see what damage it has sustained from the peltings of the winter tempests. Off they fly to the distant woods for fresh materials with which to repair their breach; or on the plain they collect the hair and fur of quadruples; or from the sandy beach pick up the weeds that have been washed there. By degrees, the nest is enlarged and trimmed, and when everything has been rendered clean and comfortable, the female deposits her eggs, and begins to sit upon them, while her brave and affectionate mate protects and feeds her, and at intervals takes her place."

In general appearance the Raven closely resembles a Crow, but it is larger. A Crow rarely is more than eighteen or twenty inches in length and has an expanse of wings of less than Larger three feet. A Raven is two feet long from bill tip to than tail tip and measures four feet or more across when its A Crow wings are spread to their full capacity. A close inspection of the two birds reveals a certain marked difference in the shape of the feathers of the neck, those of the Crow being rounded at the ends, while those of the Raven are sharply pointed. In flight the two birds may usually be distinguished, as the Raven has a way of sailing at times to an extent rarely if ever equalled by a Crow. The well-known caw of the Crow is replaced in the case of the Raven with a croak so deep, so unlike any other sound in nature that once heard it is not easily forgotten.

As indicated above Ravens build their nests on the ledges of cliffs or in trees. These usually are bulky, and as additional materials are brought year after year they grow in some instances to be very large affairs. The eggs range in number from two to seven. In color they are olive or greenish and thickly spotted and blotched with olive-brown. Twenty days of brooding are required to hatch them.

The Raven's food consists of a wide variety of objects, but evidently animal matter predominates. They eat grasshoppers, beetles, lizards, mice and young birds. They are scavengers and feast upon dead animals, both large and small.

In August, 1916, while working about Malheur Lake in the deserts of southeastern Oregon, we found Ravens much in evidence. 
During a day's travel of perhaps thirty miles about the lake I saw at least a dozen individuals. Usually only one or two would be seen at a time. One that kept in front of us for some distance alighting at intervals on the posts of a barbed wire fence, carried an object in its beak at which it would peck and pull whenever it perched. Once just as it took wing my companion fired a shot from his revolver with a view of startling the bird and causing it to drop its prey. The experiment succeeded and picking up the object we found it to be a section of a rabbit's backbone about two inches in length.

Writing of the Raven's feeding habits Alexander Wilson said: "It is fond of birds' eggs, and is often observed sneaking around the farm house in search of the eggs of the domestic poultry, which it sucks with eagerness; it is likewise charged with destroying young ducks and chickens, and lambs, which have been weaned in a sickly state. The Raven, it is said, follows the hunters of deer for the purpose of falling heir to the offal; and the huntsmen are obliged to cover their game, when it is left in the woods, with their hunting frocks, to protect it from this thievish connoisseur, who if he has an opportunity will attack the region of the kidneys, and maybe the saddle without ceremony."

Throughout all ages certain birds have been famous, and very often much significance is attached to their presence. They have been regarded as effecting the lives of human beings by bringing joy or sorrow. Thus the Cuckoo is the ancient marriage bird; the Eagle stood for strength and vigor; the Bittern represented desolation, and in our own country we have the Bluebird for happiness. The Raven which has a wide distribution throughout the world has more or less typified the coming of calamity. It has been one of the favorite birds of literature. In the ancient Hebrew writings, we find that the Raven was the first bird that Noah sent out from:

\section{A Bird of III-Omen}

the Ark. When Elijah was a refugee and was hiding by the brook Cherith we are told that the Ravens came daily and brought him food. Despite the fact that it appears to have been useful to some of the early Hebrews, Moses wrote down in his law that this was an unclean bird.

Shakespeare was fond of referring to the Raven.

In our modern American literature surely few poems so weird or depressing has ever been written as Poe's "Raven."

Two sub-species of the large Raven are recognized in this country. One, the American Raven, found in western United States, south to Guatemala, and the other, known as the Northern Raven, inhabiting Canada and Eastern United States. 


\section{SLATE-COLORED JUNCO}

BY T. GILBERT PEARSON

The National Association of Audubon Societies

Educational Leaflet No. 96

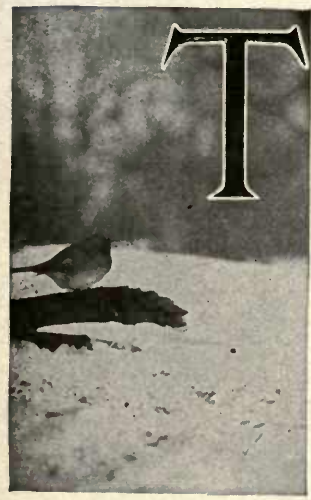

HE coming of Autumn brings many changes in the bird world. The Orioles and Tanagers depart. The Warblers leave and other familiar birds of summer disappear.

Then comes the White-throated Sparrow. the Tree sparrow, the Sapsucker, and other visitors from the North. Among these new arrivals, but not the first to appear, is the Slate-colored Junco. In thousands of dooryards they are rarely seen until the first fall of snow. Upon looking out of the window some morning one may see a dozen or more little birds flying about in the shrubbery or hopping around the doorway, looking for seeds or stray crumbs. Other small birds have this habit at times, but by the following signs you may know the Junco:

It is very nearly the size of an English Sparrow with this difference, its body is not so large and its tail is slightly longer. Its general color is dark gray, except the belly which is white. The bill is flesh colored and when it flies white feathers are shown at the sides of the tail. This description fits no other bird. Bear these points in mind and you cannot miss recognizing the Junco when he comes to visit you.

This little bird of the winter has many friends. Coming as it does at a season when other birds are few, and visiting the door-yard as it frequently does, there is small

A Winter Bird wonder that many people know it and hail with pleasure its appearance from year to year. "Snowbird" it is often called.

After the summer birds, and the migrants that are with us only for a time have departed, and the bird-life has settled down to the usual scant winter population, the Junco appears more in evidence than when it first arrived late in September. Then you will find them associated in flocks numbering from ten to fifty or more along the roadside skirted by thickets or in overgrown fence corners. Fields grown up in shrubbery and the borders of wood lands are also favorite haunts for these small winter neighbors. Here you will see them hopping about on the ground or alighting on limbs or stakes. Always they seem to be in such places that upon the call of danger they can dart by a short flight into the friendly cover of shrubbery or trees. 
As they feed they continually utter quiet little notes of content. ment, which upon being alarmed change to sharp hissing sounds that I have known people to think were caused by the bird snapping its bill.

Like all birds that spend the winter where snows fall there come times when the Juncos are hard pressed for food, and probably never a winter passes without many of them dying from lack of food and from exposure. Thus one may see very good reason exists why people should put food where they can readily find it. These birds will often eat bread crumbs, but small seeds are what they Feed the Junco prefer. The kind of bird seed one may buy at a store is good for hungry Juncos, but seeds raised in the garden will answer the purpose just as well. I will name some of them; sunflower seeds, poppy seeds, millet, oats, cracked wheat, and cracked corn will readily be taken by them. A little trouble and a very little expense is all that is necessary to tide the Juncos through a time of famine and keep them alive and well until better times arrive.

It should be borne in mind that all small birds are in constant danger of being captured and killed by Hawks, Owls, cats, and other creatures that prey upon them. When weak from lack of food the little Junco is in poor condition to escape its enemies. I recall one February when snow fell heavily for two or three days and was followed by a sleet that left a crust over the top of the snow. Also it broke down and buried the weed stalks which still held their store of seeds. Throughout the whole country there was practically no food for the Junco.

One evening upon returning late to the house I caught sight of a small bird that flew up to roost on the top of one of the pillars supporting the wide veranda of my home. On the little projection perhaps three inches wide and protected from the wind it crouched down to spend the night. An hour later I came out with a light and approached close enough to see that my little visitor was a Junco. I put some cracked wheat on the wide veranda railing close by and hoped the bird would find it when it awoke in the morning, but the wind increased in violence and more sleet fell during the night, so I am sure not a grain of it was left for our little visitor when he opened his eyes at daylight.

It so chanced that the next evening just as I came up the steps the Junco alighted on the veranda railing and attempted to fly up to the top of the pillar, but it was so weak that it was un-

\section{The Fate of the Visitor} able to gain its perch and fell to the floor. Cautiously I advanced thinking to secure the bird and feed it in the house. It flew out in the yard, however, and was soon lost in some low shrubbery. The next morning its feathers were scattered over the veranda. A cat had caught it and brought it there to eat.

John James Audubon, writing of the Junco as he knew it in Louisiana said: 


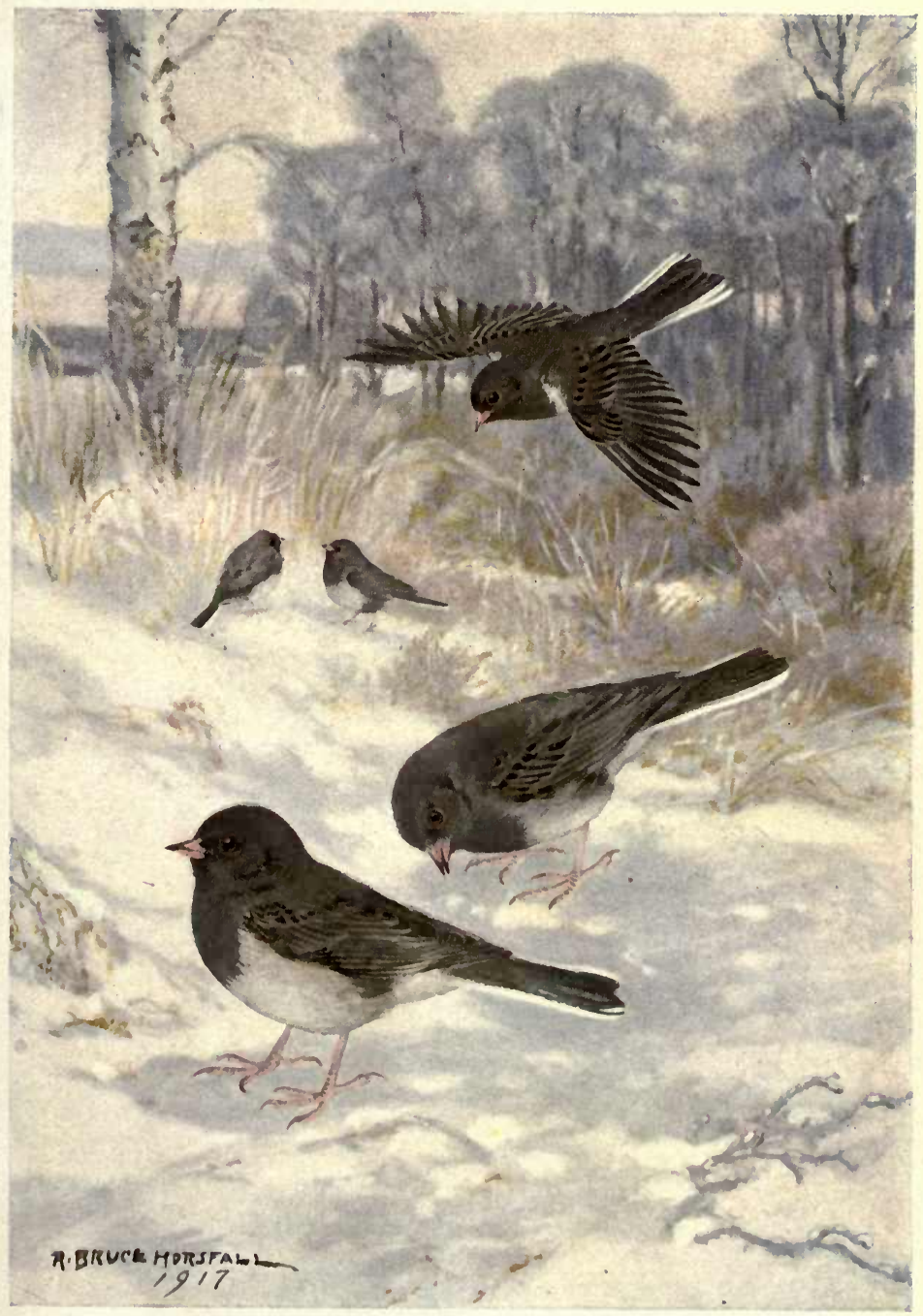

SLATE-COLORED JUNCO

Order PASEERES

Genus-Junco

Family-FrinoILLIDA

Species-HYEMALIS

National Association of Auduhon Socletles 

"Although the Snow-birds live in little families, consisting of twenty, thirty, or more individuals, they seem always inclined to keep up a certain degree of etiquette among themselves, and will not suffer one of their kind, or indeed any other bird, to come into immediate contact with them. To prevent intrusions of this kind, when a stranger comes too near, their little bills are instantly opened, their wings are extended, their eyes are seen to sparkle, and they emit a repelling sound peculiar to themselves on such occasions.

"They are aware of the advantages to be derived by them from larger birds scratching the earth, and in some degree keep company with Partridges, Wild Turkeys, and even Squirrels, for the purpose of picking up such food as these animals may deem beneath their notice. This habit is more easily observed in those which frequent the farm-yards, where the domestic Likes Company fowls prove regular purveyors to them. The report of a gun, or the unexpected barking of a dog, causes the little flock to rise and perch either on the fences or an adjoining tree, where, however, they remain only for a few minutes, after which they return to their avocations. They are particularly fond of grass-seeds, to procure which they often leap up from the ground, and dexterously seize the bending panicles.

"It is a true hopping bird, and performs its little leaps without the least appearance of moving either feet or legs, in which circumstance it resembles the Sparrows. Another of its habits, also indicative of affinity to these birds, is its resorting at night, during cold weather, to stacks of corn or hay, in which it forms a hole that affords a snug retreat during the continuance of such weather, or its recurrence through the winter. In fine weather, however, it prefers the ever green foliage of the holly, the cedar or low pines, among which to roost. Its flight is easy, and as spring approaches, the males chase each other on wing, when their tails being fully expanded, the white and black colors displayed in them present a quite remarkable contrast.

"The migration of these birds is performed by night, as they are seen in a district one day, and have disappeared the next. Early in March, the Snow-bird is scarcely to be seen in Louisiana, but may be followed, as the season advances, retreating towards the mountains of the middle districts, where many remain during the summer and breed."

Near the close of Audubon's narrative he makes this significant statement:

"Their flesh is extremely delicate and juicy, and on this account small strings of them are frequently seen in the New Orleans market, during the short period of their sojourn in that district."

This of course was written many years before the Audubon Law, which protects these birds, was enacted by the Legislature of Louisiana.

The Junco passes the winter in suitable localities throughout eastern United States from the Gulf of Mexico on the south to southern Can- 
ada on the north. In summer it is distributed generally from New England north throughout Canada as far west as Alaska. They also breed in the upper parts of the Catskill Mountains and along the ridge of the Appalachian Mountains south to Georgia. On many of the mountains of western North Carolina I have found these birds a most abundant species. In fact on some of the mountains one may encounter more Snow-birds on a day's tramp than all other species combined. Blueberries are very common in these mountains and in summer the Snow-bird varies its usual diet of insects with these wild berries which grow so profusely about its abode.

The nest is built in a depression in the ground often on the side of some little bank or among the mingled roots and sod of an upturned tree. If, during the summer, one comes upon a Junco with a little worm or the larvae of some insect in its bill, he need only wait a few minutes and the bird will probably betray its Nest nest by going to feed its young. I have often had and Eggs this experience. In fact the Snow-bird's nest has been for me one of the easiest nests to find. In every instance I have found it by watching the birds going to it. The nest itself is usually well hidden and the small amount of dried grass and moss of which it is composed so well blends with the surroundings that one would hardly expect to discover the little cradle with its four or five speckled eggs or young.

In the spring the Junco has a song. It is not very loud and is not very long, but hearing it as one usually does when few other birds are giving voice to their happiness, it makes a strong appeal to the ear of the bird-lover.

The Slate-colored Junco (Junco hyemalis) is the common Junco with which most people are acquainted. No less than eight other subspecies have been described. Two of these will be mentioned. In the southern Alleghany Mountains and breeding as far south as northeril Georgia there is a race of Juncos ( $J . h$. carolinensis) that is slightly larger and its markings are a little different from the common Junco. Still another race, the Montana Junco, (J.h. montanus) is found in the Rocky Mountains breeding from southern Alberta to Idaho and passing the winter in Arizona, Texas and New Mexico. 


\title{
LEAST TERN
}

\author{
By T. GILBERT PEARSON
}

\section{The National Association of Audubon Societies Educational Leaflet No. 97}

One of the daintiest and most confiding of our sea-birds is the Least Tern. Except where they have been extensively shot or otherwise dis turbed they often exhibit a lack of fear that is astonishing.

On the North Carolina coast I have frequently seen them light on the beach within fifteen or twenty feet of where I was standing in the open. Their aggression when one approaches their nests is equa!led only by their near relative, the Arctic Tern.

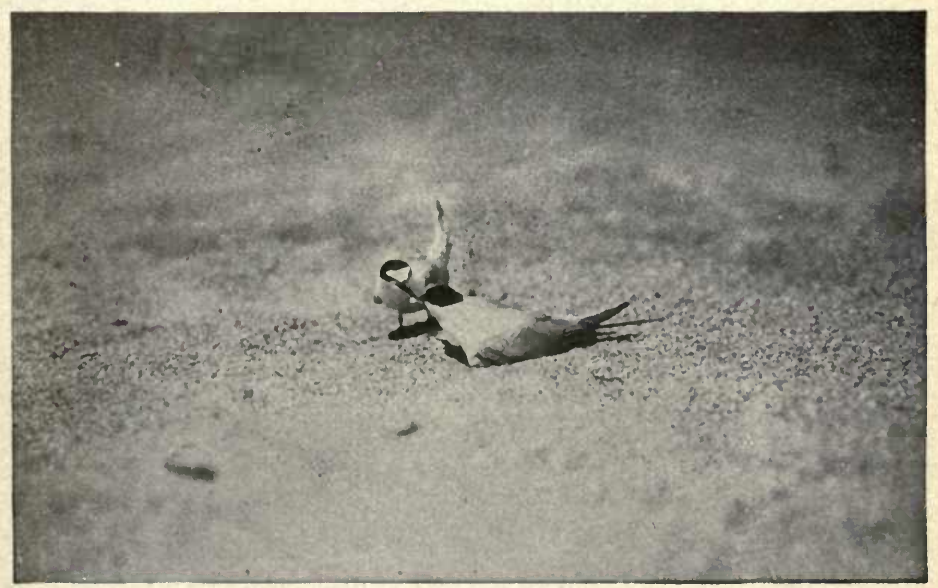

LEAST TERN FEEDING ITS MATE ON THE NEST

Photographed by E. H. Forbush on an island off the Massachusetts Coast

Forty years ago Least Terns were among the most numerous seabirds inhabiting the North American continent. Their colonies, situated on islands or points of sandy peninsulas, could be found with great frequency as one travelled along our eastern coast from Maine to Texas. They also were found interiorly in some places, especially up the Mississippi River, and to a limited extent its tributarics. Here the birds bred on small shoals in the rivers. In those days they ranged as far north as Nebraska, Missouri and Iowa. 
Audubon, in his Birds of America, speaks of finding the Least Tern at a point far north of where it is commonly known today. He says that he met with it on "the western shores of Labrador, where I found it abundant, and breeding in the beginning of June, 1833." Continuing, he says, "On the fourteenth of August following I observed them at Newfoundland moving southward in detached parties of young and old, against a strong breeze and uttering their clamorous cries."

Their beauty of plumage, the ease with which they might be killed, and their vast numbers all contributed to their popularity with the feather-trade, and during the eighties, before the Audubon work became effective, their slaughter constituted one of the blotches on our American life.

It was the custom in those times for men to fit our vessels with provisions, ammunition and collecting materials sufficient to last them for days or even weeks. These piratical crews sailed the coast, killing and skinning the Least Terns, and incidentally many other birds, for the great New York millinery houses.

This shooting was carried on almost entirely in spring and summer, when the birds were gathered in colonies for the purpose of rearing their

\section{Club or Gun} young. It was very easy to kill them in numbers, as they flew in screaming clouds low over their eggs and young that dotted the breeding territory. In fact, it was not always necessary to use a gun. So dense were the clouds of birds that the hunters frequently would hurl clubs or short poles among the flying hosts. From two to a half dozen birds could easily be disabled at a stroke. A half hour's work at clubbing and shooting by two or three men was often sufficient to secure several hundred birdsall that the crew could skin during the remainder of the day.

By this method the colonies on Long Island were exterminated in a short time. A big killing went on along the coast of Virginia. On Cobbs Island, 10,000 specimens were taken in a single season. A woman representing a New York millinery house directed this work. She took with her two or three skinners and employed the local gunners to kill the birds, paying them ten cents for each one brought in.

So rare had the Least Tern become on Cobbs Island in 1892, when the writer visited the place during the height of the breeding season, that less than a half-dozen individuals were seen. The terror of man was so strong upon them that when they caught sight of two of us coming down the beach they flew with startled cries toward the open sea, and we did not see them again during our subsequent excursions along the beach the next three or four days.

Two inhabitants of Morehead City, North Carolina, Augustine Piner and Joseph Royal, were famous slaughterers of birds in those days, and the numbers of Terns and Egrets that these two men and their crews gathered for the feather business ran into the hundreds of thousands.

Methods

Employed

By both of these men I have been given intimate, detailed descriptions of their killing and skinning cruises. From them I learned that they frequently found the shooting of Terns profitable at other places than on the breeding-grounds. The Terns often gathered in numbers about inlets 


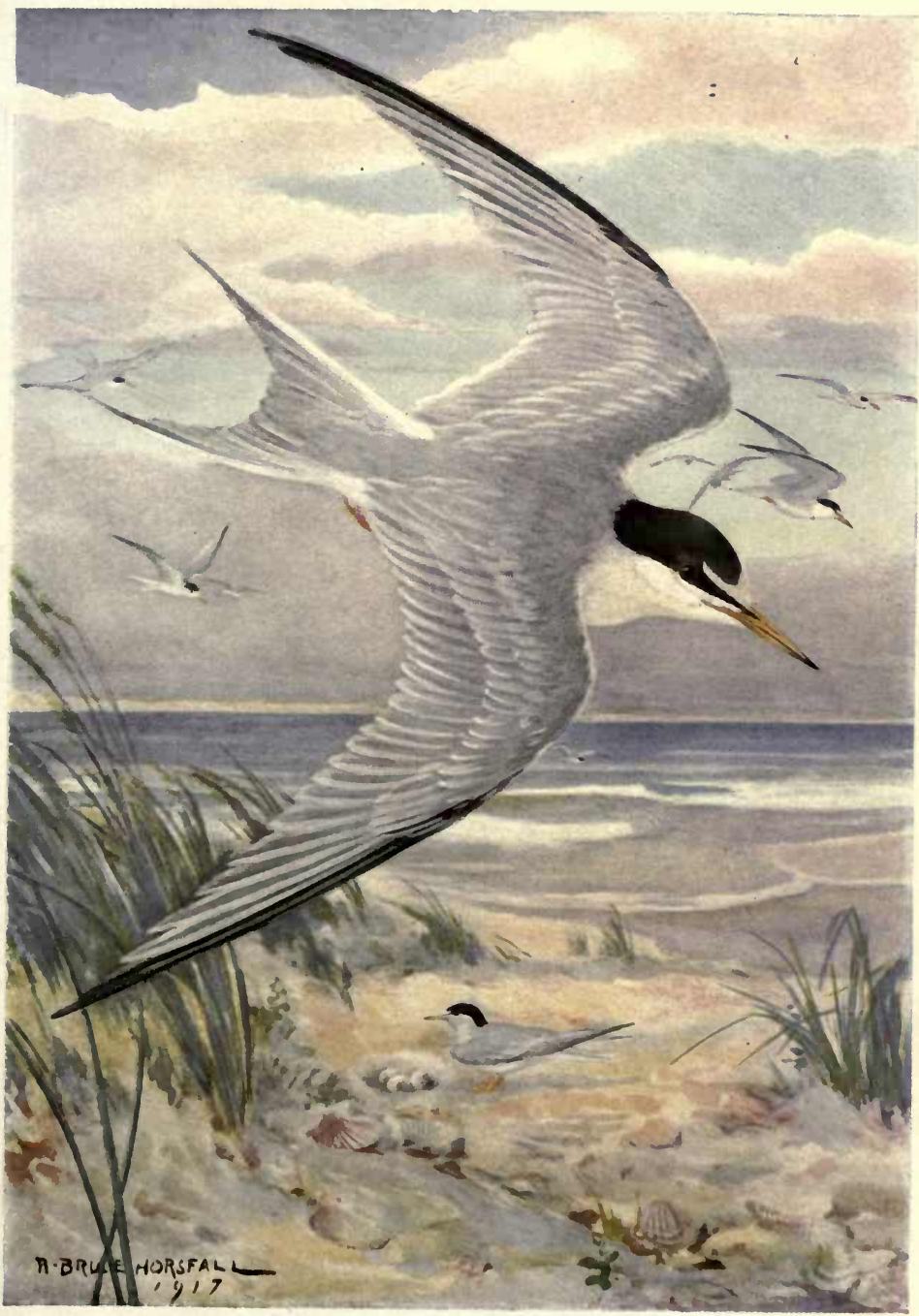

\section{LEAST TERN}

Order-LONOIPENNES

Genus-STERNA

Family-Laride.

Species-antillarum 

to the sea, where the constant ebb and flow of the tide evidently furnished excellent opportunities for feeding.

As soon as one bird was shot down on the water the others in the neighborhood would come flying about overhead, dipping down and shouting at the strange appearance of their helpless comrade. It was then easy to make a large bag of birds in a few minutes. If the flock was wild and difficulty was experienced in getting down the first bird all they needed to do was to tie a handkerchief to a stick and throw it in the air. This decoy falling to the water was sufficient to bring the nearest Terns quickly within range of the guns. Because of its small size the entire skin of the Least Tern was usually worn for hat decoration. In the case of the larger Terns it was often customary to use only the wings.

For many years the killing of these birds has now been illegal and the wardens of the National Association of Audubon Societies, and in two cases the wardens of State Game Commissions, have been guarding the summer colonies of Terns along our coast. In some sections the Least Tern is recovering its numbers to a limited extent. For example, when the first Audubon warden began guarding the colonies on the North Carolina coast, which was in the year of 1903 , so scarce had the Least Tern become that only fourteen eggs were laid that year. By careful guarding, the birds increased until three years later by fairly accurate count made by the warden in charge, five hundred and seventy-seven Least Terns

Results of

Protection are believed to have been raised. The number steadily increased another year or two, when heavy storm-tides sweeping the low-lying islands destroyed the eggs and young alike and for a time prevented further increase.

The Audubon Law in North Carolina put an end to this slaughter, but only when the Least Tern had decreased almost to the point of extermination and the other Terns of the region had become vastly reduced in numbers.

This killing also went on along the coast of Scuth Carolina, Georgia, Florida and Louisiana; in fact, wherever the Least Tern was found there came men with guns, ammunition, arsenic, and plaster of Paris ready to transform the living bird into a hat decoration.

On the coast of Massachusetts, chiefly as a result of numerous cats brought by summer residents, the Least Tern appears to be passing away. According to E. H. Forbush, who in 1917 carefully examined the few remaining Massachusetts Tern islands, the principal colonies are now located at Cape Cod and on and in the neighborhood of Martha's Vineyard.

There is a small colony on the sandy point of Raccoon Island, South Carolina, and a few are breeding at Dry Tortugas, Florida. In June, 1918, Carlos Earle reported that there were a number of Least Terns breeding on one or more islands near the mouth of Tampa Bay. On June 30, 1918, I

\section{Colonies \\ Today}

found a group of perhaps fifty pairs feeding their young on a small sandy island in Caxambas Pass, Lee County, Florida. There are some colonies on the islands in Mississippi Sound, and on June 16, 1918. 
while cruising with Stanley C. Arthur I found about one hundred birds that had their nests on some small islands in Calcasieu Lake, Cameron County, Louisiana. A few still persist along the outer islands off the coast of Texas, especially in the neighborhood of San Antonio Bay. Some fairly healthy colonies exist on the coast of Southern California. Outside of the United States the birds breed in limited numbers in the Bahama Islands, West Indies, British Honduras and Venezuela.

The nest of the Least Tern, like that of many other sea-birds, is of a most primitive character. It consists usually of a slight hole in the sand without any attempt at lining. Most authorities give the number of eggs deposited as three or four. Of the hundreds of nests that the writer has examined more contained two than four.

When the Least Terns select as a breeding-place an island occupied by other Terns their colony is always, as far as I have observed, situated in an area quite to itself. In other words, Least Terns seldom if ever lay their eggs in close proximity to nests of other birds. The eggs are about an inch and a quarter long and nine-tenths of an inch wide. In color they are brownish white spotted and dotted with chocolate.

Of the notes of this bird Audubon wrote, "The common note of our Least Tern resembles that of the Barn Swallow when uttered about its nest, being as smartly and rapidly repeated at times."

In common with the Black Tern, these exquisite little birds at times feed to some extent on insects, but their food in the main appears to

Eats Insects, consist of minnows and small shrimp. I have often

Minnows and watched them along our southern coast as in little Shrimp companies they flit along over the creeks and wind for miles through the extensive salt marshes. They wander into the soutkern bays and at times up the rivers, but along our Atlantic seaboard appear never to breed except on outer sandy islands and spits.

They begin their migration northward in April and by the middle of May are usually well distributed throughout their summer home. June and July are the months when the duties of rearing young go forward. Apparently these birds do not rear two broods in a season, but if the eggs or young are destroyed by high tides, fish crows, crabs, or other causes a second laying shortly takes place.

As the accompanying illustrations will show the general appearance of the Least Tern suggests a white bird with a black cap. In reality the wings, back and tail are of a pearlish gray and the under parts are pure white.

In length from bill tip to tail tip it is nine inches, or an inch shorter than the average Robin. Its wing expanse, from tip to tip, is twenty inches, or four inches more than the expanse of the Robin's wings.

The Least Tern belongs to the Order of Longipennes, the longwinged swimmers, and to the family Laridae.

This and other Educational Leaflets are for sale, at 5 cents each, by the National Association os Auquoon societies, 1974 Broadway, New York City. Lists given on request. 


\section{LEAST BITTERN}

By T. GILBERT PEARSON

\section{The National Association of Audubon Societies}

Educational Leaflet No. 98

One morning, early in May, I pushed an old flat-bottomed boat through the reeds growing along the shore of a shallow southern lake until reaching an open place, I dropped my baited hook among the lilypads. The sun had but recently risen, and the plant-life on every hand was glistening with dew. The morning was very still, and the squawk of a slow-flying Heron came distinctly across the water from a distance of a quarter of a mile. On a nearby bush a Red-winged Blackbird balanced and saluted with song the new day. Kongquer-rce, kong-quer-ree, came his musical voice over and over again. In the woods along the shore Cardinals called incessantly, and a Carolina Wren threw to the air a tempest of melody. A Woodpecker somewhere was tapping on a dead limb, and a Fish Crow flew over without a sound.

It was good to be on this quiet lake, where no farmhouse was within sight and into whose solitude the shriek of a locomotive whistle never entered. While sitting here enjoying the tranquil surroundings, I suddenly noticed a movement among the tops of a clump of rushes, perhaps fifty feet away. Three or four of them appeared to be swaying ever so gently, and yet they surely were in motion. A moment later there appeared an object just coming into view from below, indistinct and yet real. It appeared the same color as its surroundingsas though a small portion of the denser rush clump had quietly moved upward into view. And

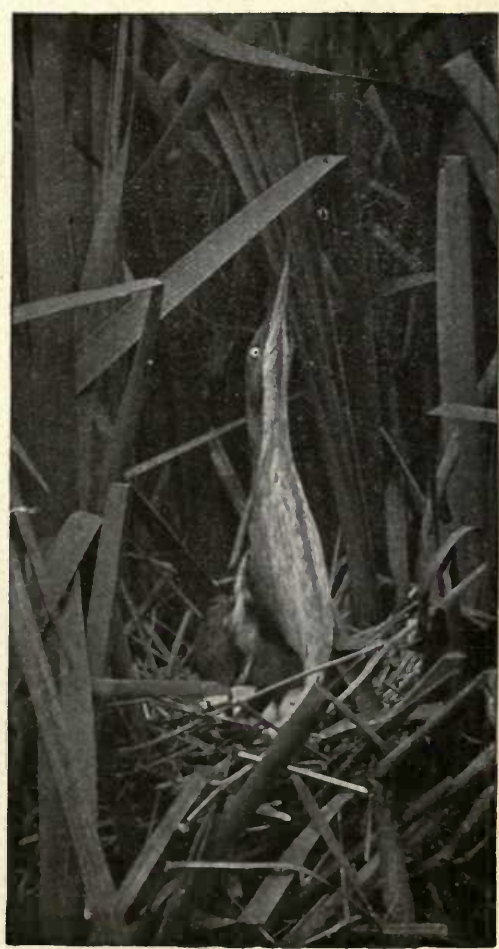

FEMALE LEAST BITTERN "FREEZING" UPON APPROACII OF ENEMY

Photographed by Arthur A. Allen 
then, as I gazed, the motion of the reeds ceased and the object blended with the reed stalks and disappeared. Puzzled and curious, I waited, but nothing more happened. Laying my fishing-pole on the lily-pads, I picked up the paddle and slowly and cautiously pushed the boat forward. Not until the prow of the boat came to a stop within 5 feet of the spot I was so intently watching were my eyes able to again outline the yellowish brown mass whose movements I had watched a few moments before. Grasping the stem of a stalwart reed, with body erect and long bill pointed skyward, there stood a bird, silent and motionless as the rushes around it. Can any bird of the wilderness, by remaining motionless, be better hidden in its surroundings than the Least Bittern? If so, I have yet to meet it. After watching my neighbor for a minute, or two, I

\section{When Fear}

Came slowly arose and started toward the front end of the boat. At this, the bird lowered its head and, with one bound, sprang from its hiding. The instant for flight had come; the light yellow eyes gazing at me from either side of its upturned bill had told it that its deception had been discovered, that a probable enemy was fast approaching.

With dangling legs and labored beating of wings the bird flew over the reeds, much as young birds fly, and, looking at it for the first time, one might expect it to fall from sheer weakness. However, the flight soon became stronger, and, stretching its legs out straight behind, it was soon going with ease and at a fairly rapid rate. Three hundred yards away it dropped from sight among the rushes and was seen no more.

Turning to look again at the cluster of rushes from which the bird had flown, I discovered its nest-a large, double handful of rush leaves and water grasses, perhaps eight inches across the top. It was held in place by the surrounding rushes and was supported by a mass of the previous year's growth that had died and were bent down. In the slightly depressed top lay four pale blue eggs about an inch and a quarter in length. No wonder the bird wanted to hide, perhaps feeling that when it flew its treasures might be revealed. Later in the day I again visited the nest and found the bird at home, or, as I have always believed, the mate of the one that was there in the morning, for its behavior was totally

Different

Behavior

different. As I approached, instead of raising its bill as if in silent supplication to heaven, and "freezing" as still and rigid as the rushes about it, it merely squatted low, spreading its wings as if to shield the nest from view. With the feathers of its neck raised and head drawn back in a threatening attitude, it showed clearly its anxiety and willingness to strike if the intruder upon its solitary domain should approach too closely. That it was quite capable of doing this was quickly shown when, upon reaching out my hand, that sharp and strong beak made a vicious stroke which, had the blow gone home, would most assuredly have drawn blood.

Sixteen days are required for the eggs of the Least Bittern to hatch. but long before this period had passed my duties had taken me elsewhere, and I was not to see the babies in their cradle, or ever to learn whether they escaped the dangers that beset the little wild birds that begin life in the nuarsh.

Another time, in a distant state, I again invaded the haunts of the 


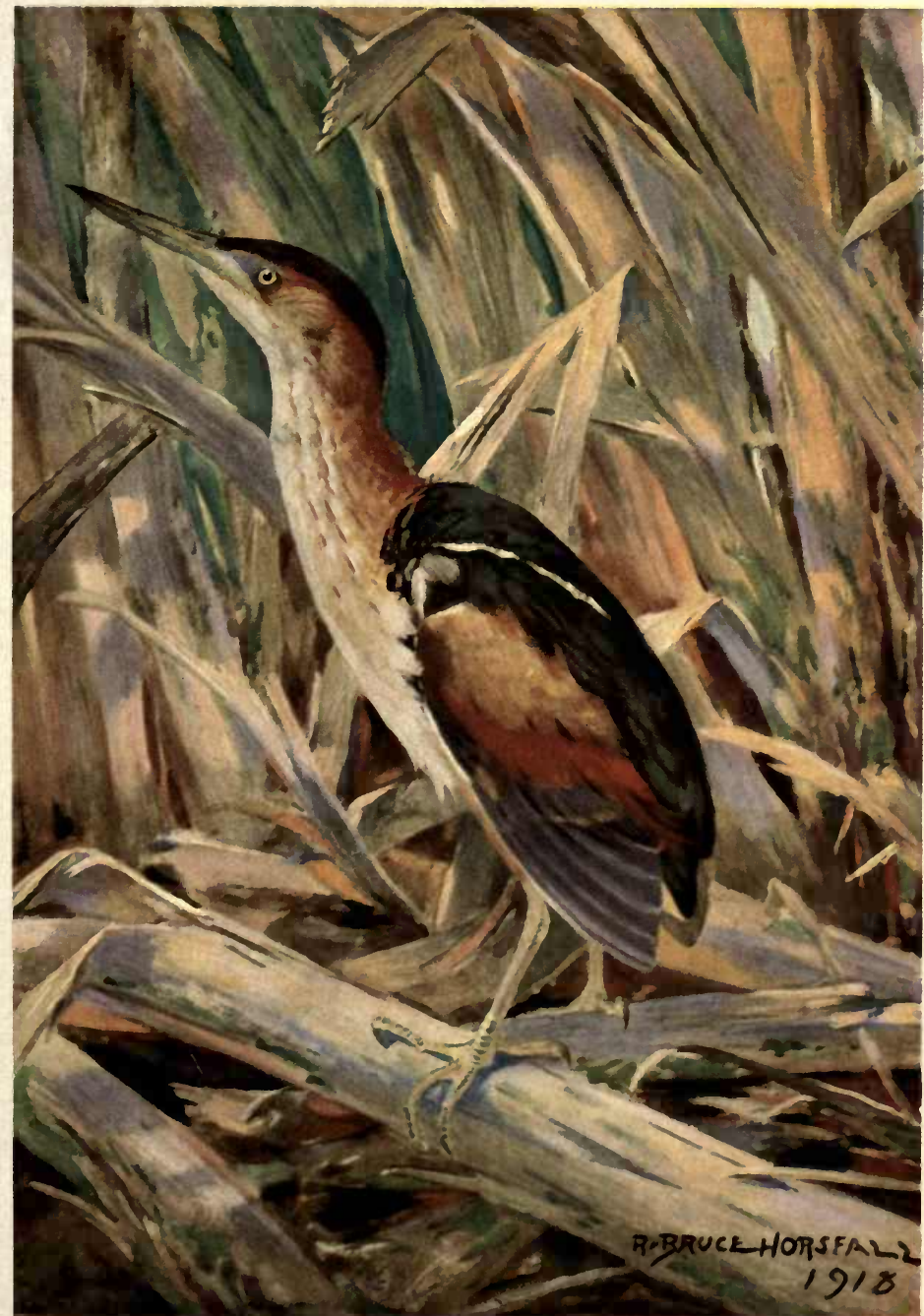

LEAST BITTERN

Order-HERODIONRS

Genus-IXORRYCHUS

Family-ARdeIDE

Spocles-EXILIS

National Assoclation of Audubon Societies 


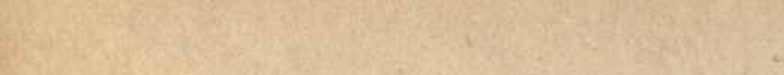

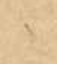


Least Bittern. I came upon three young birds, in a bush, that probably were only a day or two out of the nest. Evidently, they had traveled some distance from the place of their hatching, for there was no shelter within a hundred yards where the nest could have been concealed, and all search failed to reveal it. I was passing within five feet of their hidingplace when I discovered them. All were standing perfectly still, with their bodies compressed rigid and upright, and their long necks and bills pointing straight upward. Foolishly, I tried to take one in my hand, and it immediately flew, but either through weakness or some other cause, fell into the water before going far. I picked it up and restored it to the bush, but it at once attempted to escape, this time falling almost at once. Fearing that by repeated annoyance the bird might overdo its strength and perhaps drown, I backed the boat slowly away, and in a few minutes had the satis-

Young

Birds

faction of seeing the young Bittern rejoin its companions on the bush. The other two being wiser, or less frightened perhaps, had made no effort to escape, and, so far as could be seen, had never changed their position since my first intrusion.

There are some birds that seek their living while hopping or flitting in bushes or trees; others as they walk or hop along the ground; some as they circle through the air far above the ground, and still others while swimming on the water or diving below its surface. This Bittern belongs to the family of Herons, and, as is well-known, Herons secure their prey by wading in shallow water and striking out with their long, sharp bills. Although a Heron the Least Bittern does not go fishing in this way. Its body is light and its toes long and flexible. Apparently, it feeds entirely where the water is too deep for the bird to wade. With lowered head and bill extended, it goes through the marsh grass or reeds, grasping first one stalk and then another, as it proceeds just above the water.

The great naturalist, John James Audubon, tells us in his writings about the kind of food this bird eats. He says:

"The food of this bird consists of snails, slugs, tadpoles, or young frogs or water-lizards. In several instances, however, I have found small shrews and field-mice in their stomach. Although more nocturnal than diurnal, it moves a good deal about by day in search of food. About noon, being doubtless much fatigued, they are not infrequently

Audubon

Knew

Them observed standing erect on one foot, and so soundly asleep as to be easily knocked down or even caught by the hand, if cautiously approached."

The Least Bittern is fully 16 inches in length, provided the measurement is made from the tip of the bill to the end of the nail of the long little toe. From tip to tip of its wings, when these are spread, the distance is $1 \frac{1 / 2}{2}$ feet. It is astonishing how a bird of this size can pass with such ease through the thick clusters of reeds and rushes among which its life is spent. Audubon, who kept some of them in captivity for a time, found that they could easily pass through a crack only one inch in width, and this without any special effort or evidence of distress on the part of the bird. Like the Rail and some other water birds, it has the power of greatly compressing its body, thus making it thinner than at normal times. 
The home of the Least Bittern is in the fresh-water marshes. Rarely, along the Atlantic coast and down along the Gulf of Mexico, I have seen the bird in salt-water marshes, but all search for its nest in these localities has been in vain. One characteristic of the Herons is their habit of coming together in numbers for the purpose of laying their eggs. Very often hundreds, or even thousands, of several different species will be thus congregated. The bird we are discussing, however, does not have this habit. In a growth of buttonwood bushes, in the shallow waters of a small Florida lake, I once found five nests of the Least Bittern within a few yards of one another, but such occurrences, in my opinion, are rare. Usually, the birds seem to prefer to be alone. On a few occasions I have found them nesting in bushes in the midst of a colony of Boat-tailed Grackles, but I suspected that they chose the locality because it seemed especially suitable for their nesting purposes and not because they sought the society of their large black neighbors.

Enemies the Least Bittern certainly has. Water-snakes capture the young and perhaps at times eat the eggs. Muskrats, found in nearly every marsh, are to be dreaded, as are Minks and Hawks. Fish Crows

\section{Enemies \\ to}

Avoid are ever on the lookout for eggs, and perhaps this is the reason why the birds bend downward the tops of the rushes to shield the eggs from above. The draining of marshes, which thus destroys their feeding and nesting places, has caused these birds to become scarce in many parts of the country.

The Least Bittern ranges over a large part of North America, being found in summer from Oregon and the southern Canadian provinces southward throughout the United States, West Indies, Central America and northern South America. When winter comes, the birds in Canada and the United States retire southward, and none are known to pass the winter north of the region immediately bordering the Gulf Coast.

This and other Educational Leaflets are for sale, at 5 cents each, by the National Association of Audubon Societies, 1974 Broadway, New York City. Lists given on request. 


\title{
THE RED-EYED VIREO
}

\author{
By T. GILBERT PEARSON
}

\section{The National Association of Audubon Societies \\ Educational Leaflet No. 99}

Any boy or girl in the eastern United States who begins to study wild birds, will probably not proceed very far before learning to know the Red-eyed Vireo. To be sure, it is one of our small birds, measuring only about six and one-quarter inches in length, and this fact together with its rather dull greenish coat and whitish underparts, renders it of unstriking appearance, yet it is very well known. And why? Chiefly because it sings so much. It announces its arrival in Spring with such loud

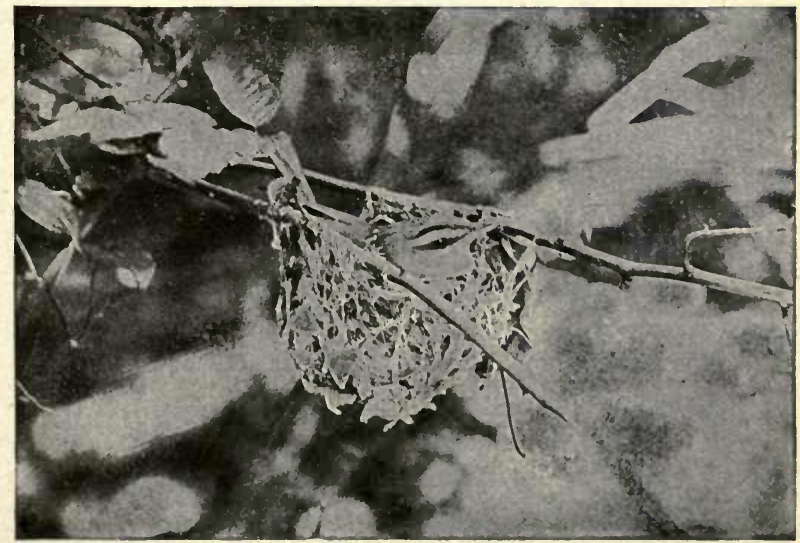

RED-EYED VIREO ON NEST

Photograph by Dr. Frank M. Chapman

notes that many mistake its calls for those of the Robin. For three full months and more it is with us, and every day, from long before sunrise until evening its simple songs are repeated over and over again. No other bird of our land retains its energy and enthusiasm for song as does the Red-eyed Vireo. Neither the anxieties of the nesting season nor the irritations of the molting days appear in the least to affect its behavior in this regard. 
No wonder, therefore, the young bird-student soon makes its acquaintance. Even as I write these lines, on a hot afternoon late in June, I can hear the notes of a Vireo coming in through the open window. The bird is out there among the trees of a vacant lot, where the small boys have dug their trenches and are sending forth their volleys of vocal musketry. The savage shouts of youth and the song of the Vireo have been going on together now for some weeks, and the authors of all the din apparently have never noticed each other.

The past four years a pair of Vireos has spent the summer in the trees of this vacant lot. One June day I found the nest near the outer

The Nest

in the Lot end of a white birch limb. The nest could easily be reached by a grown person standing on the ground beneath. It was a beautiful cradle hung in the fork of two twigs, and was made mainly of strips of bark and plant fibre. A piece of white string and some scraps of paper decorated the outer sides. It contained four white eggs lightly spotted around the larger end. From these there emerged in time four little birds that for many days engrossed their mother's attention. After they had flown away I took the nest and placed it on the wall of my study. The next Spring, while passing near the place with a little friend of mine, I went over to the limb and showed her the place from which I had cut the twig to take the nest. Just as I took it in my fingers I was surprised and delighted to find a new Vireo nest not more than twelve inches from where the other had been and in it sat the mother bird. In due time this nest also was removed to the study.

The past year I could not find the nest, although the birds were about and the male was heard singing every day. When Autumn came, however, and the leaves had fallen, the nest was discovered in another tree a few yards away at a height of at least twenty feet from the ground. Only yesterday I learned that for the fourth time a Vireo's nest has been found in the vacant lot. One of the boys discovered it suspended from a swinging limb just over a path along which commuters hurry every morning for trains. So I went out to look, and found that it held one vigorous young bird that cried most outrageously when I pulled the limb down a few inches in order to remove a dead one whose head hung over the edge.

One of the questions which naturally arise in connection with this record of nests, is whether they were all built by the same pair of birds. It would seem that such was probably the case, although there is no possible way of knowing.

In a few weeks now the Vireos will be gone and for more than eight months we shall hear no more of them. Travelling southward chiefly by 


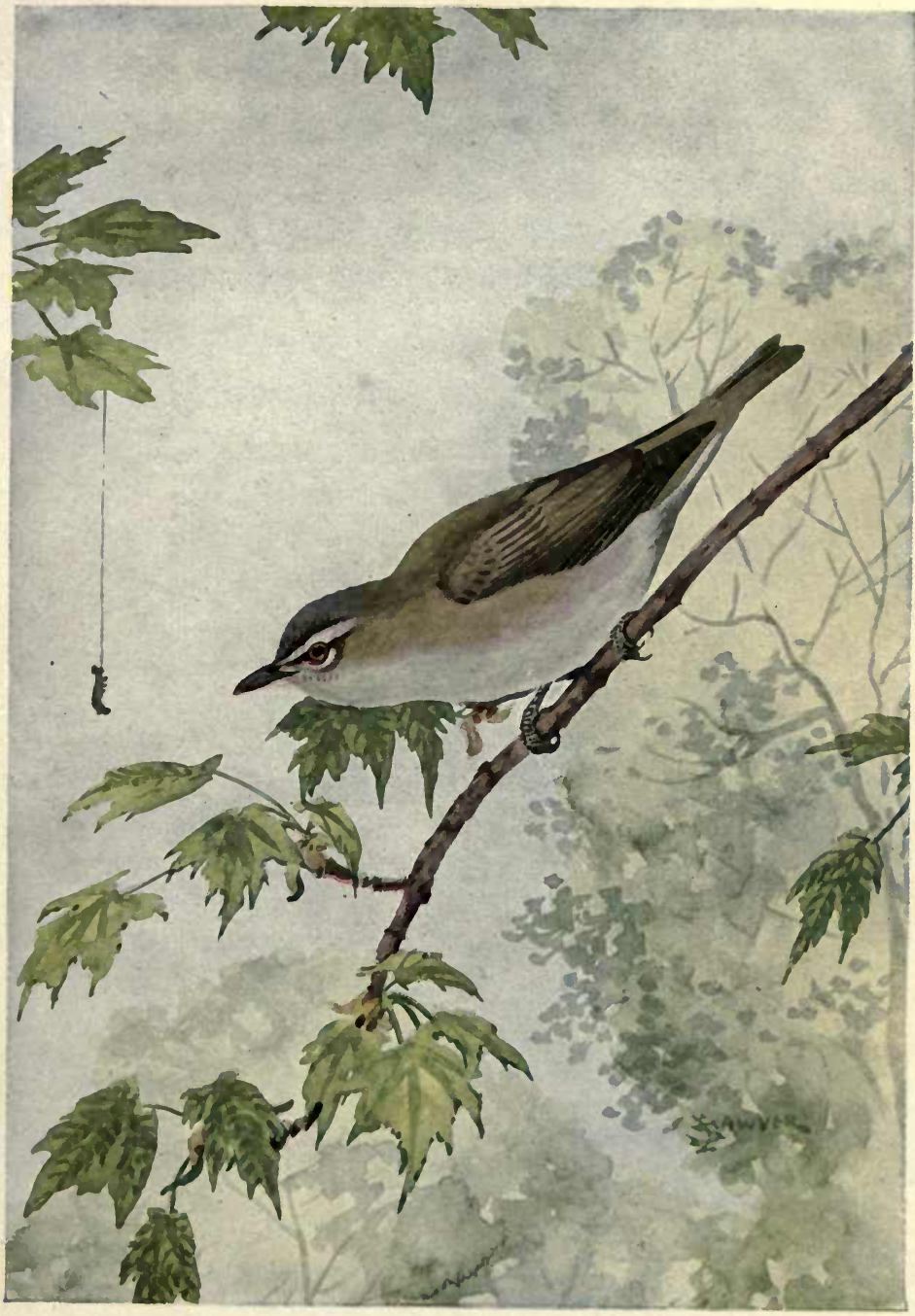

RED-EYED VIREO

Order-Passeres

Genus--VIREOSYLVA
Family-VIREONIDAE

Specles-Olivacra 


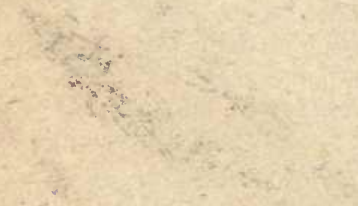

$$
\begin{aligned}
& 13
\end{aligned}
$$

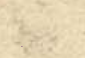

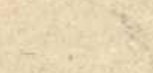

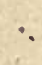


night, stopping to rest in groves, orchards and forests as they proceed, the Vireos journey on, some of them passing downward through western Texas and Mexico to the far-away Tropics. Others reach the Gulf of Mexico along the coast of Louisiana, Mississippi or Western Florida, and there,

Travels of the Vireo

after a brief pause, they plunge out across the tumbling waters of the sea and never sight land again for six or eight hundred miles until they reach Yucatan or Central America. Through the interminable jungles of South America they continue their journey until they reach the regions of the Equator, many going on southward into southern Brazil.

Here, in the great steaming forests, they remain for some months until the instinct of migration again begins to beat in their veins. Then our little friends turn northward, and those that have survived in due time gain the boundaries of the United States. A little time passes, and then one Spring morning we again hear their cries in the grove about the house. Wilson Flagg once said that the words which the Red-eyed Vireo sings are clearly these: "You see it-you know it-do you hear me? Do you believe it ?" Never do I pause to listen to one of these birds without recalling these words, for the music comes in a series of groups of short, clear, questioning calls and Mr. Flagg's interpretation is perhaps as accurate as any that has been suggested.

How little we know of the courtship of birds! Dr. W. M. Tyler, of Lexington, Massachusetts, writing in "Bird Lore" some time ago related this remarkable experience:

"This afternoon about six o'clock, I saw a pair of Red-eyed Vireos acting in a manner new to me. They were in a small gray birch tree, twelve feet from the ground, and almost over my head. The two birds were very near each other; so near that their bills might have touched, although they did not. The male, or at least the bird who played the active

\section{Making \\ Love} rôle, faced the side of the other bird, so that their bodies were at right angles. The bird who, from her passive actions, I assumed, but perhaps wrongly, to be the female, sat crouched low on her perch, with the feathers slightly puffed out. But, although in the attitude of a sick bird, she appeared in good health, I thought, and I am certain, that she gave close attention to the strange actions of her companion. The bird I have called the male, and I think it is safe to so consider him, was constantly in motion. He rocked his body, especially his head, from side to side, his bill sweeping over the upper parts of the other bird, never touching her, nor, indeed, coming very near it, for his head was above and a little to one side of her back. In swinging from side to side, he moved slowly, but with a tenseness suggesting strong emotion. In contrast to 
the fluffy female, the feathers of the male were drawn closely about him, so that he looked slim and sleek. The neck seemed constricted, giving him a strangled appearance."

Few birds are as tame when on the nest as is the Vireo. Only this Spring I pulled down a twig where a bird was brooding her eggs and actually touched the bird on her breast with my finger before she would leave, and when I went away she immediately returned to her vigil. Dr. Anne E. Perkins, of Gowanda, N. Y., has written a story about the female Vireo that was so unusually tame, she tried the experiment of feeding it. In her account she says :

"I hastily caught a small, succulent green grasshopper and slowly, cautiously, advanced my hand till the grasshopper was within easy reach of the bird. The male kept up a constant scolding in the top of the apple tree containing the nest, while I stood trying to win his wife's confidence. It seemed many weary minutes that she sat motionless or with a slight suspicion of fear in her little red eye, cowering

Feeding

a Vireo closer to the eggs. Then, just as my hand ached intolerably and I was about to withdraw it, she made a slow movement of the head towards me-and hastily snatched the grasshopper. I was delighted and praised her audibly for her discrimination and confidence. She devoured several more grasshoppers very readily, once the ice was broken. The male bird all the time seemed anxious and kept up a continual scolding. I made visits once or twice daily thereafter, and she was perfectly fearless about taking food, eagerly accepting small flies and grasshoppers, invariably refusing worms, and showing preference for grasshoppers.

"She would allow me to stroke her, close my hand about her, almost lift her from the eggs, reach under her, etc. Once or twice she left the nest and flew at her mate when he was making demonstrations of fear and distress, knocked him smartly off his perch, snapping her bill and scolding vigorously, then took her place again on the eggs. It was exactly as if she told him that she would not be interfered with and that he could attend to his own affairs."

This and other Educational Leaflets are for sale, at 5 cents, by the National Association of Auduhon Societies, 1974 Broadway, New York City. Lists given on request. 


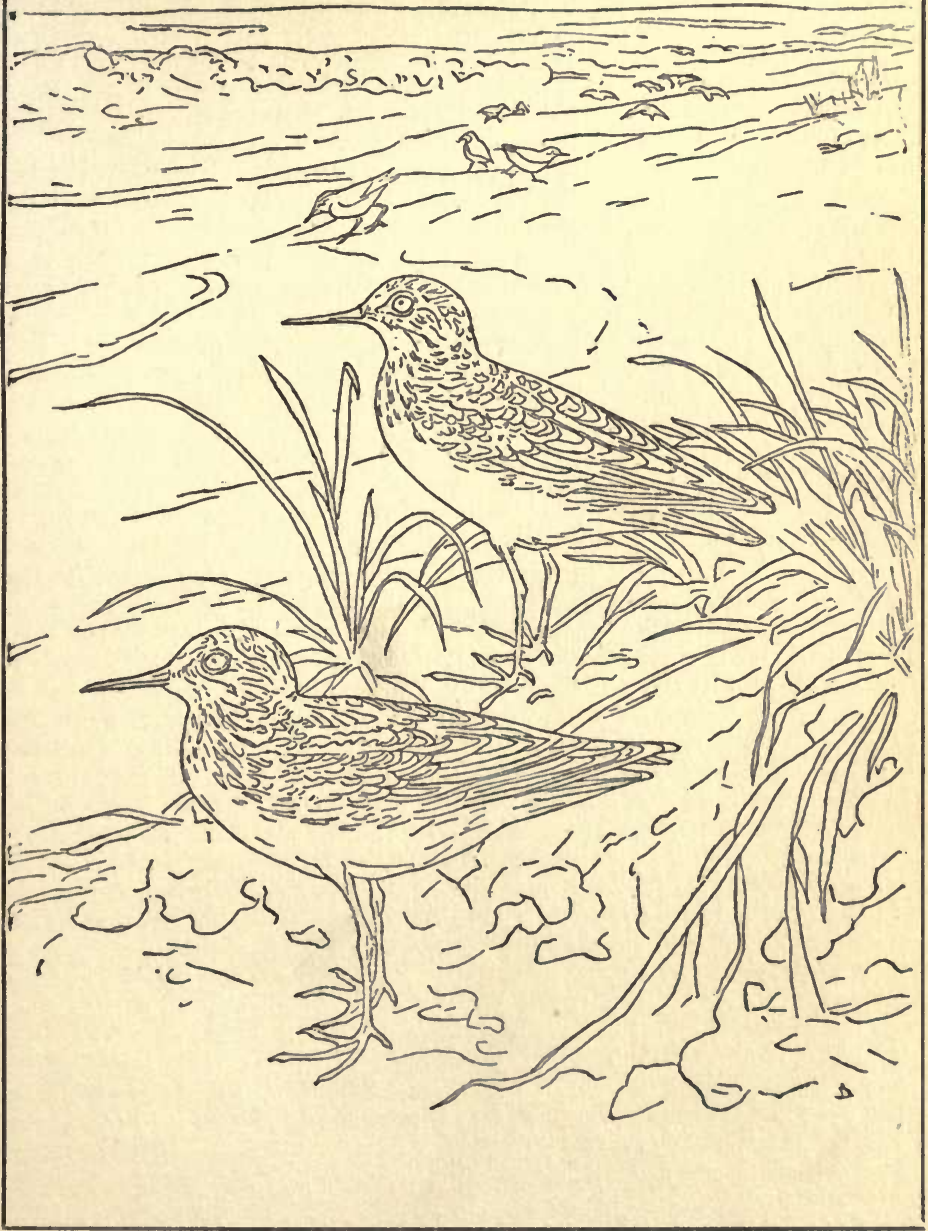

LEAST SANDPIPER (Upper figure)

SEMIPALMATED SANDPIPER (Lower figure)

Order-Limicore

(One-half natural size)

Pisozia minutilla (upper figure) Ergunatzs pusillus (lower figure)

National Association of Audubon Societies 


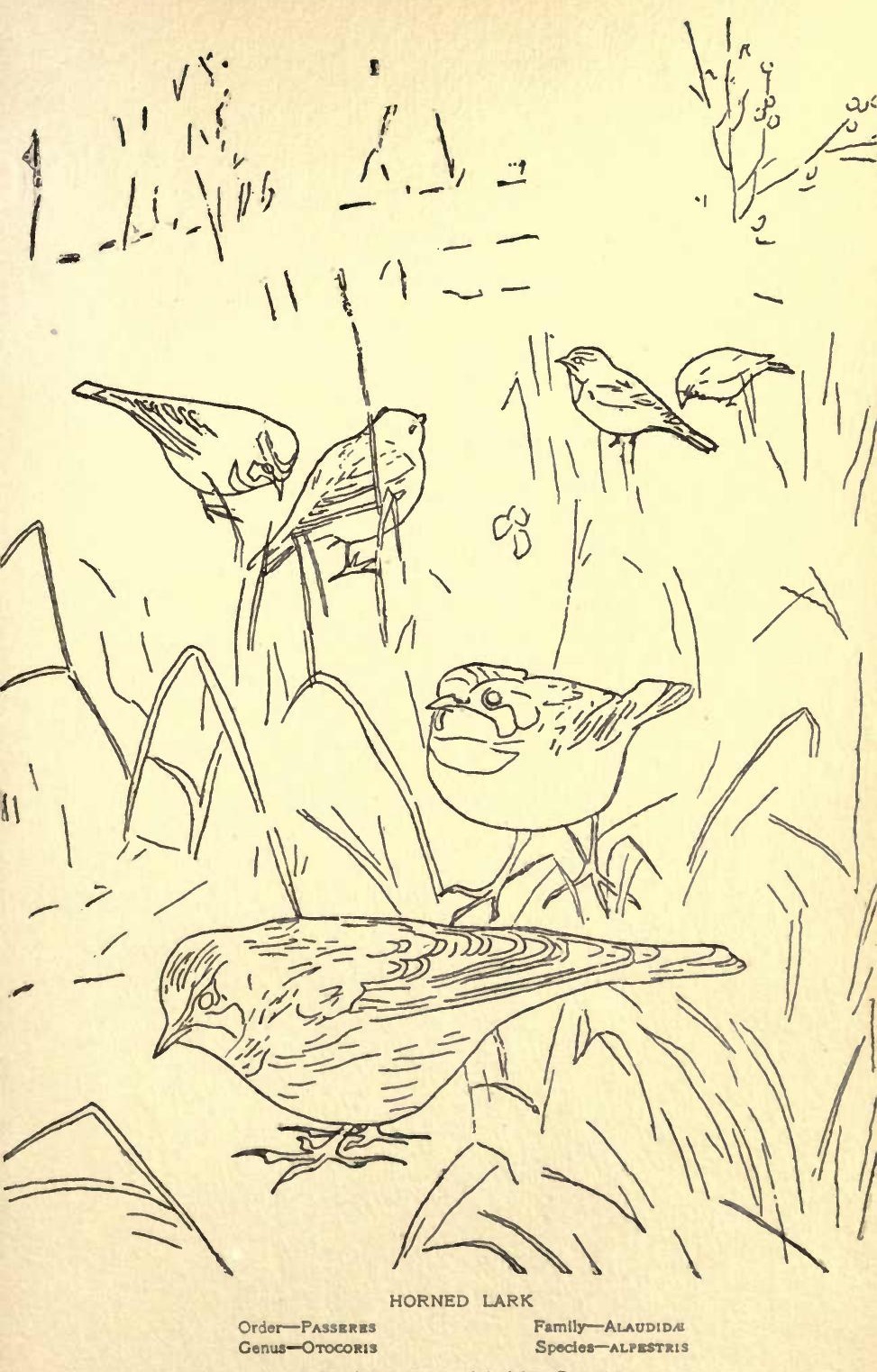

National Association of Audubon Societles 


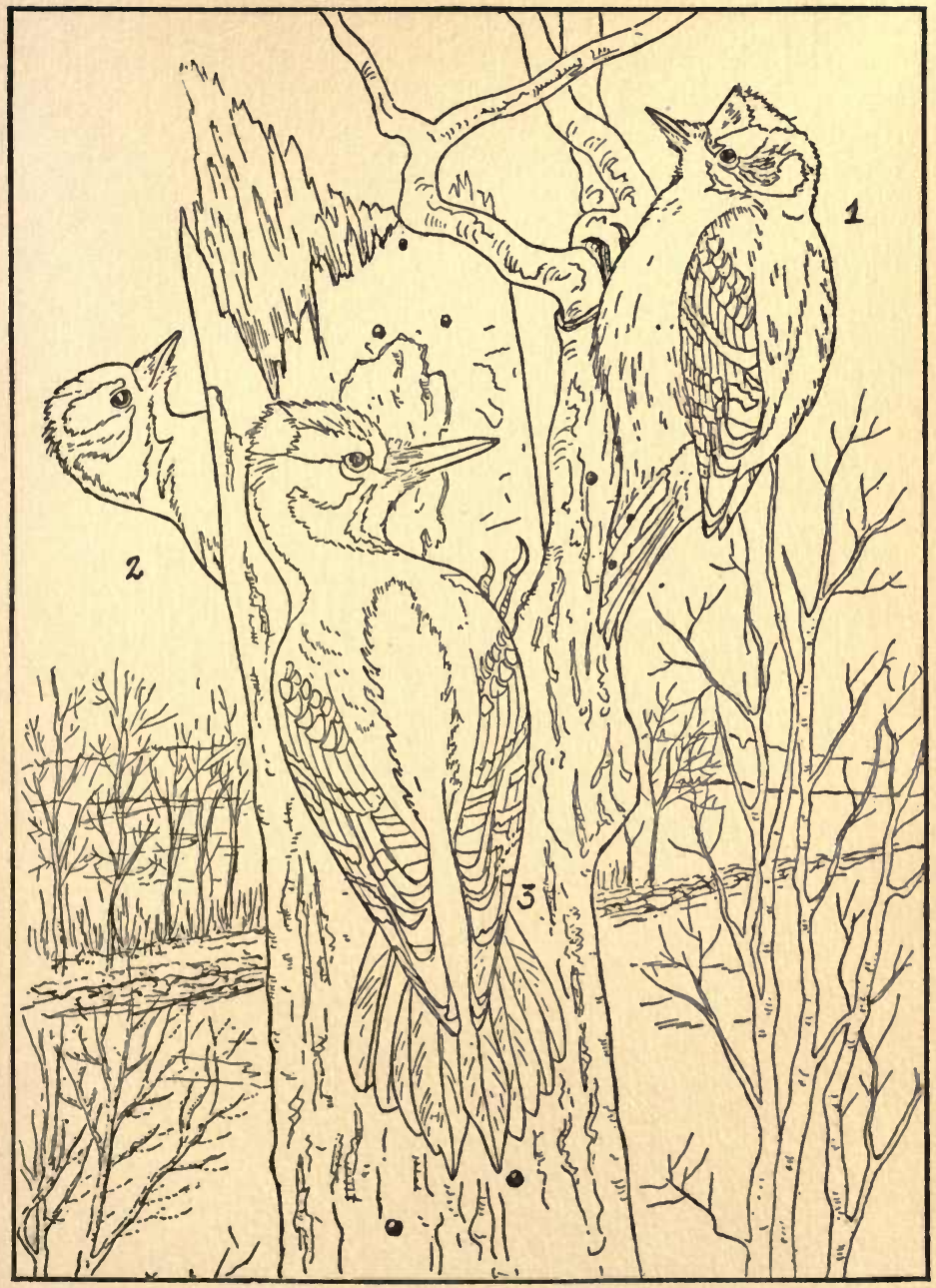

DOWNY (FIGS. I AND 2) AND HAIRY WOODPECKERS (FIG. 3) Order-Picz Family-Picide

Genus-Dryozntes

Species-Punzcens and Vulzosus

National Association of Audubon Societies 
. 


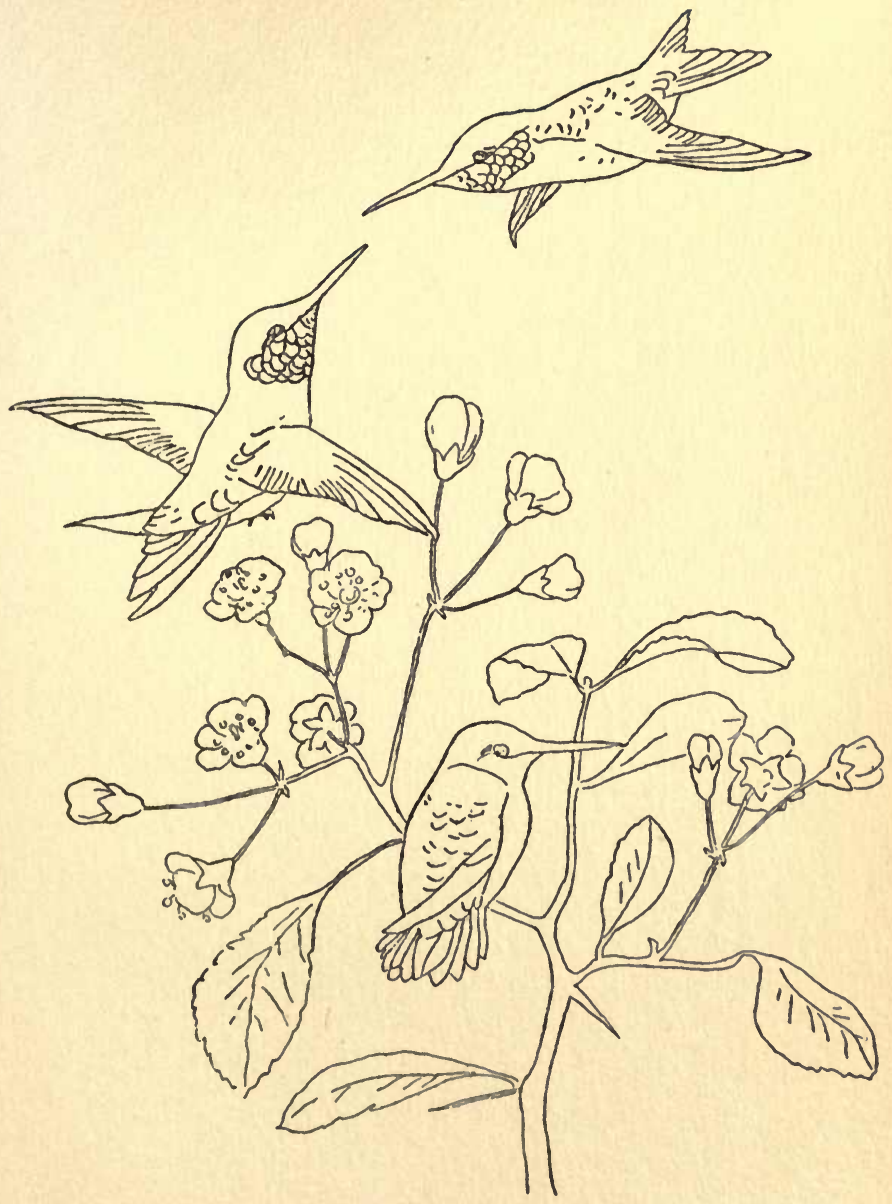

RUBY-THROATED HUMMINGBIRD

Order-MACROCHIRES

Family-TrochILIDA

Genus-ARChILOCHUS

Specles-Colusais

National Association of Audubon Societies 


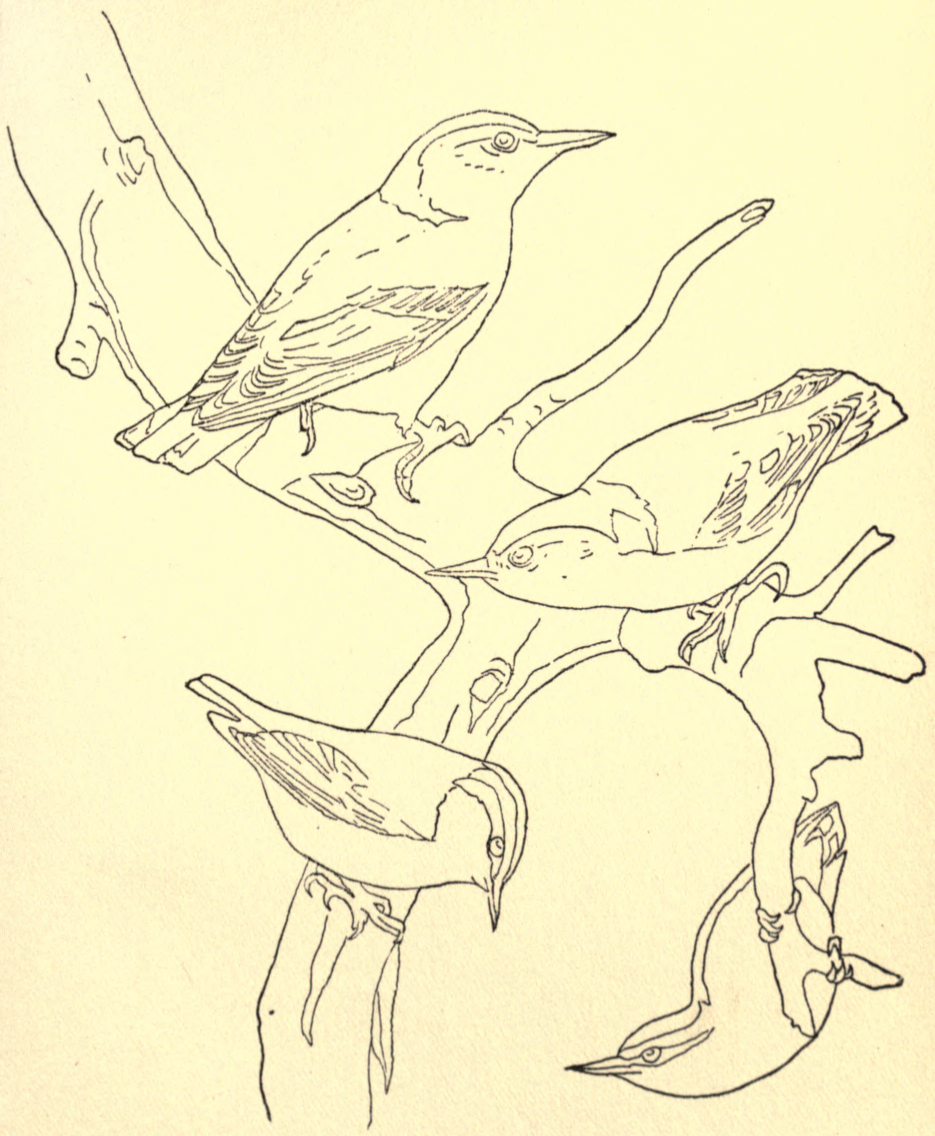

WHITE-BREASTED NUTHATCH

(Upper Figures, Male and Female)

RED-BREASTED NUTHATCH

(Lower Figures, Male and Female)

Order-PAsseres Family-SitTid E 


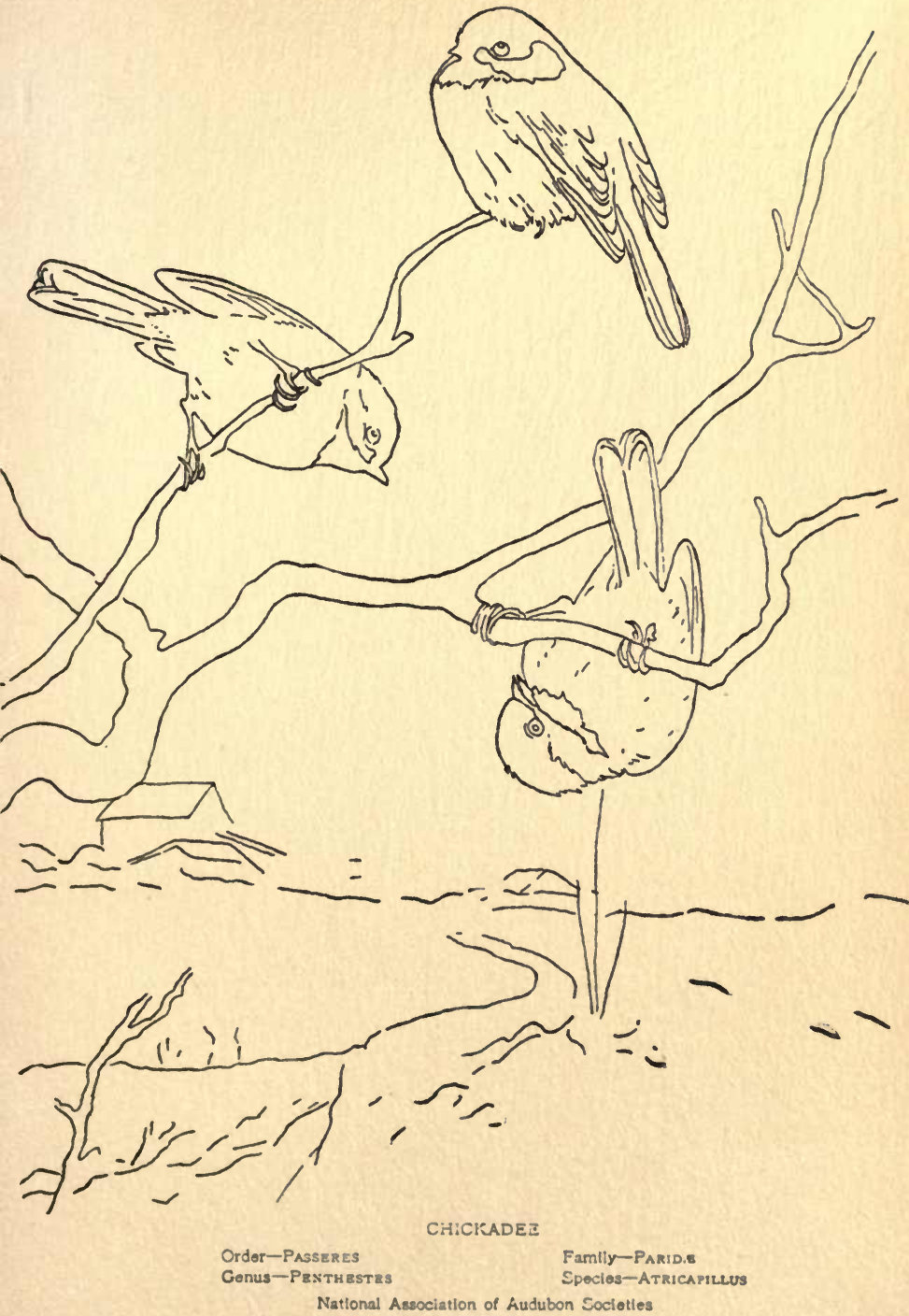




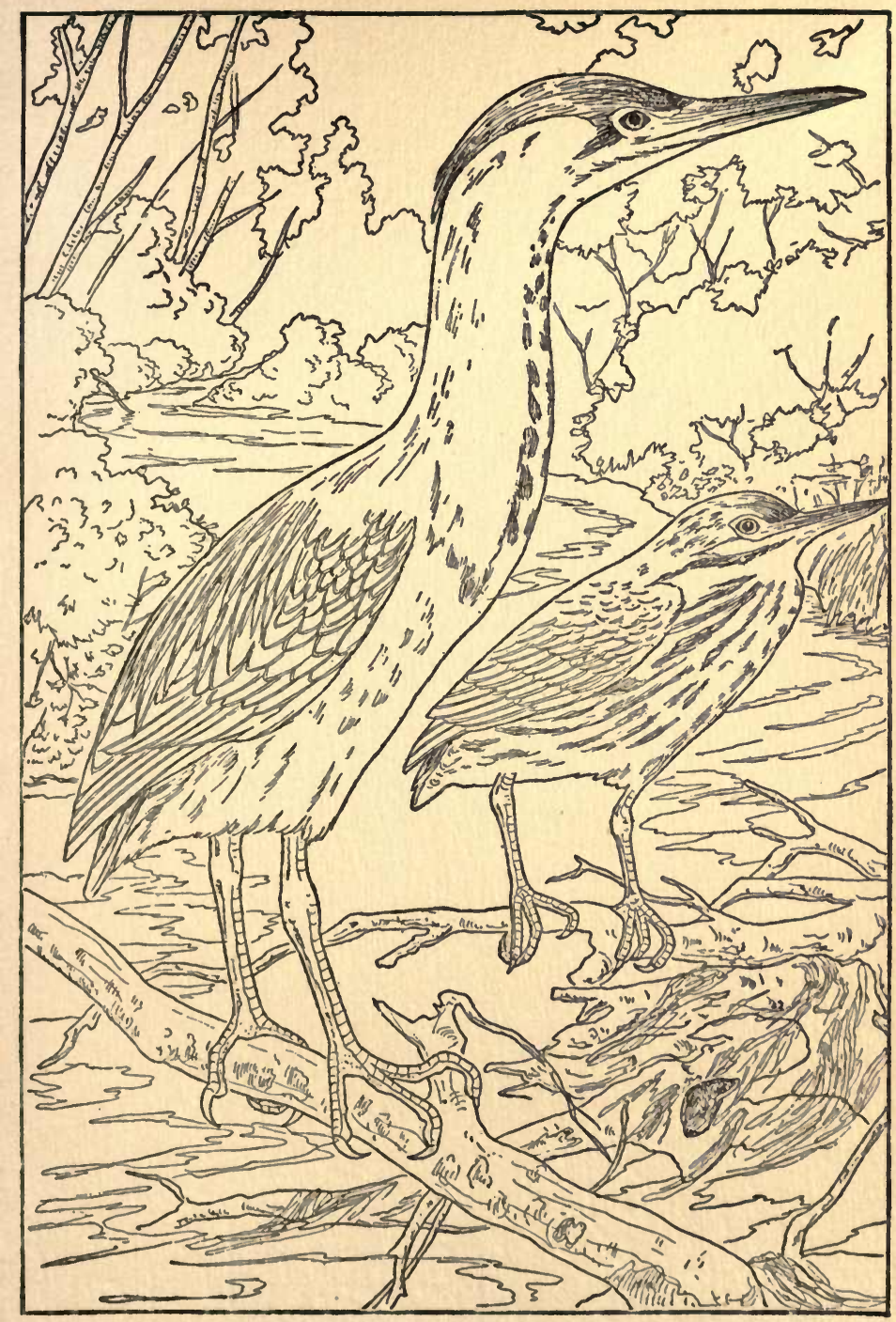

GREEN HERON

Order-Herodiones

Family-ArdeIds

Genus-Butorides

Species-VIREscens

National Association of Audubnn Socicties 


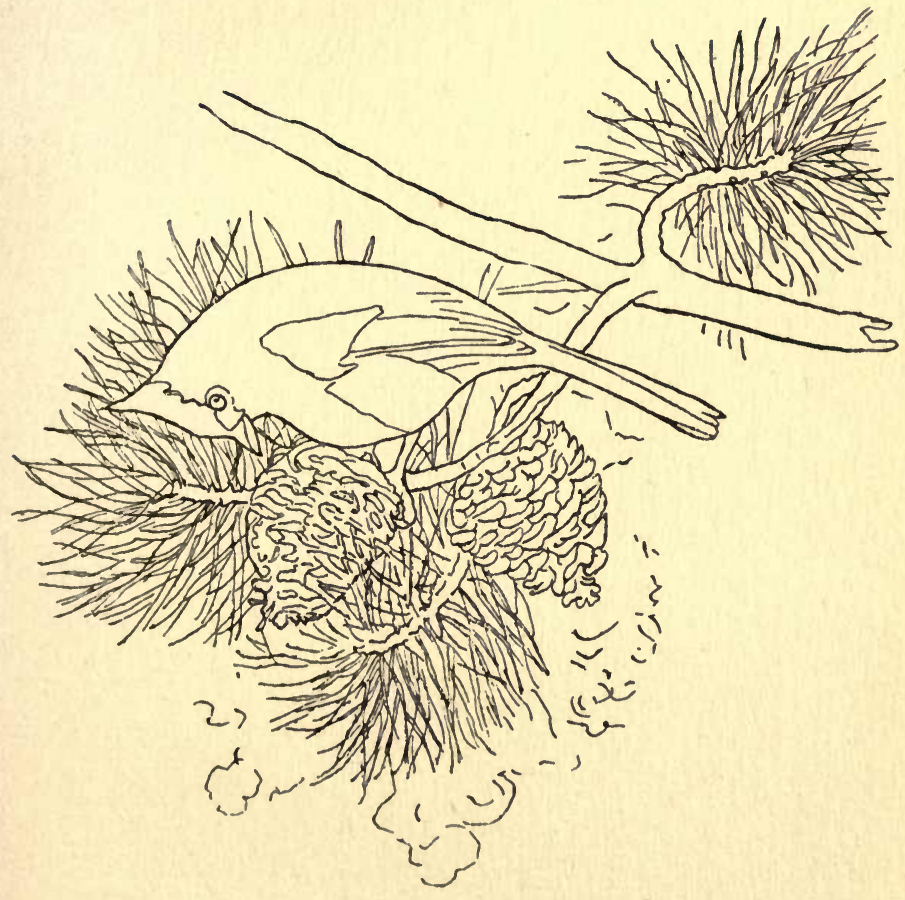

TUFTED TITMOUSE

Order-PAsseres

Genus-BeoLOPHUS
Family-PARIDA

Specles-ricolor

National Association of Audubon Societles 



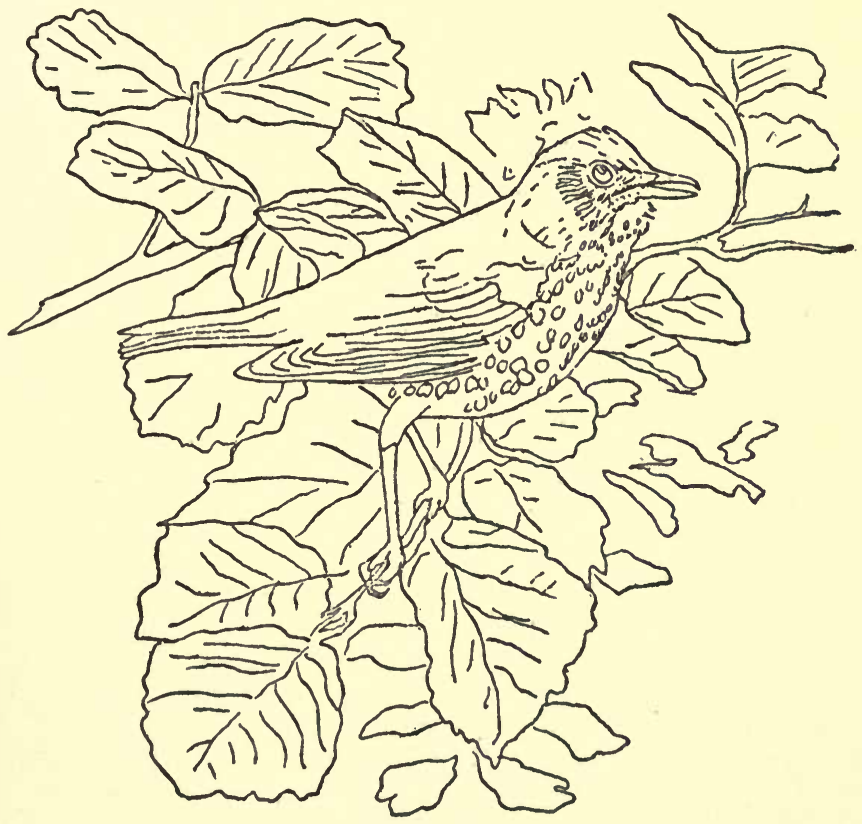

WOOD THRUSH

Order-Passeres

Genus-HyLOCICHLA
Family-Turdide

Species-musteuina 


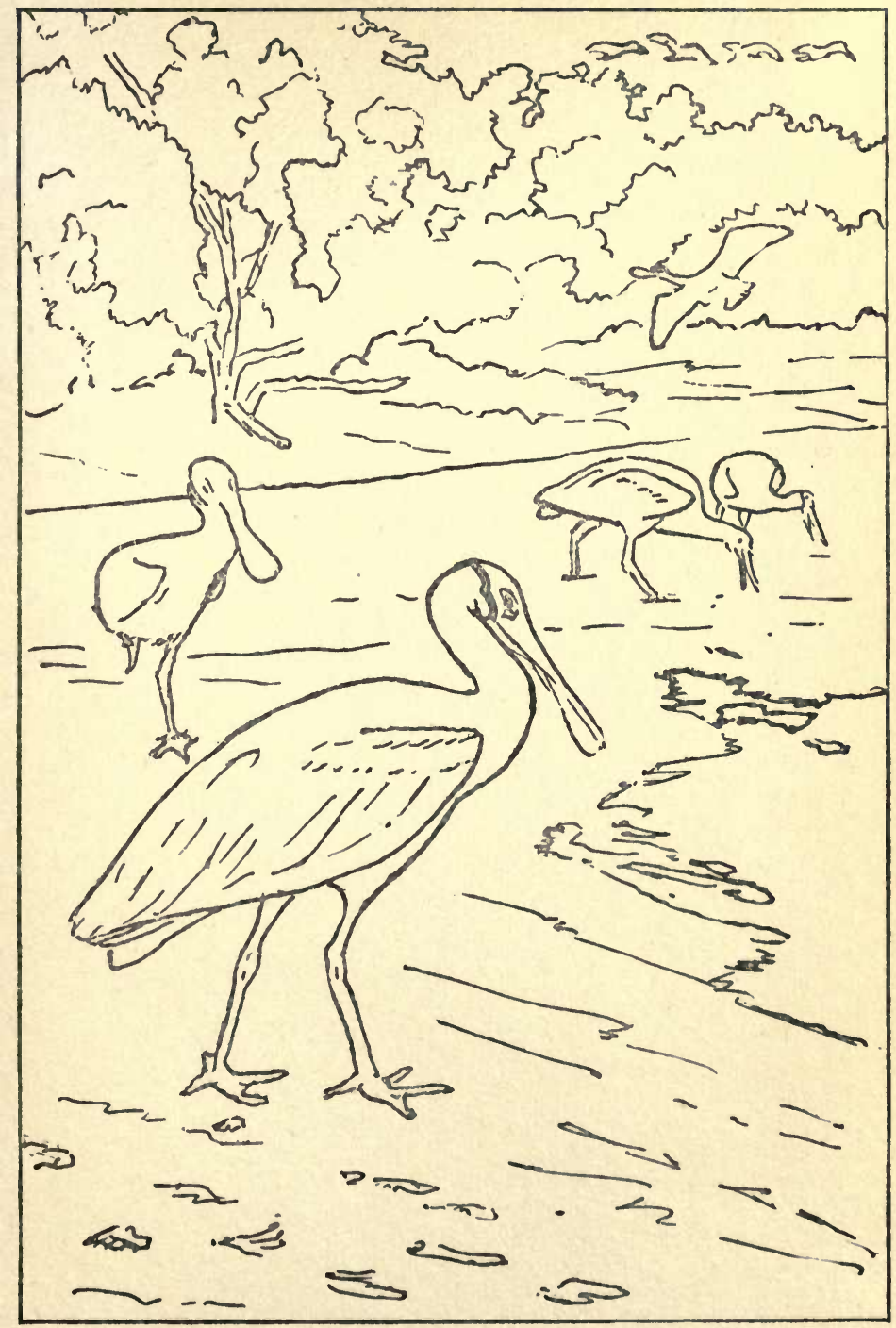

ROSEATE SPOONBILL 


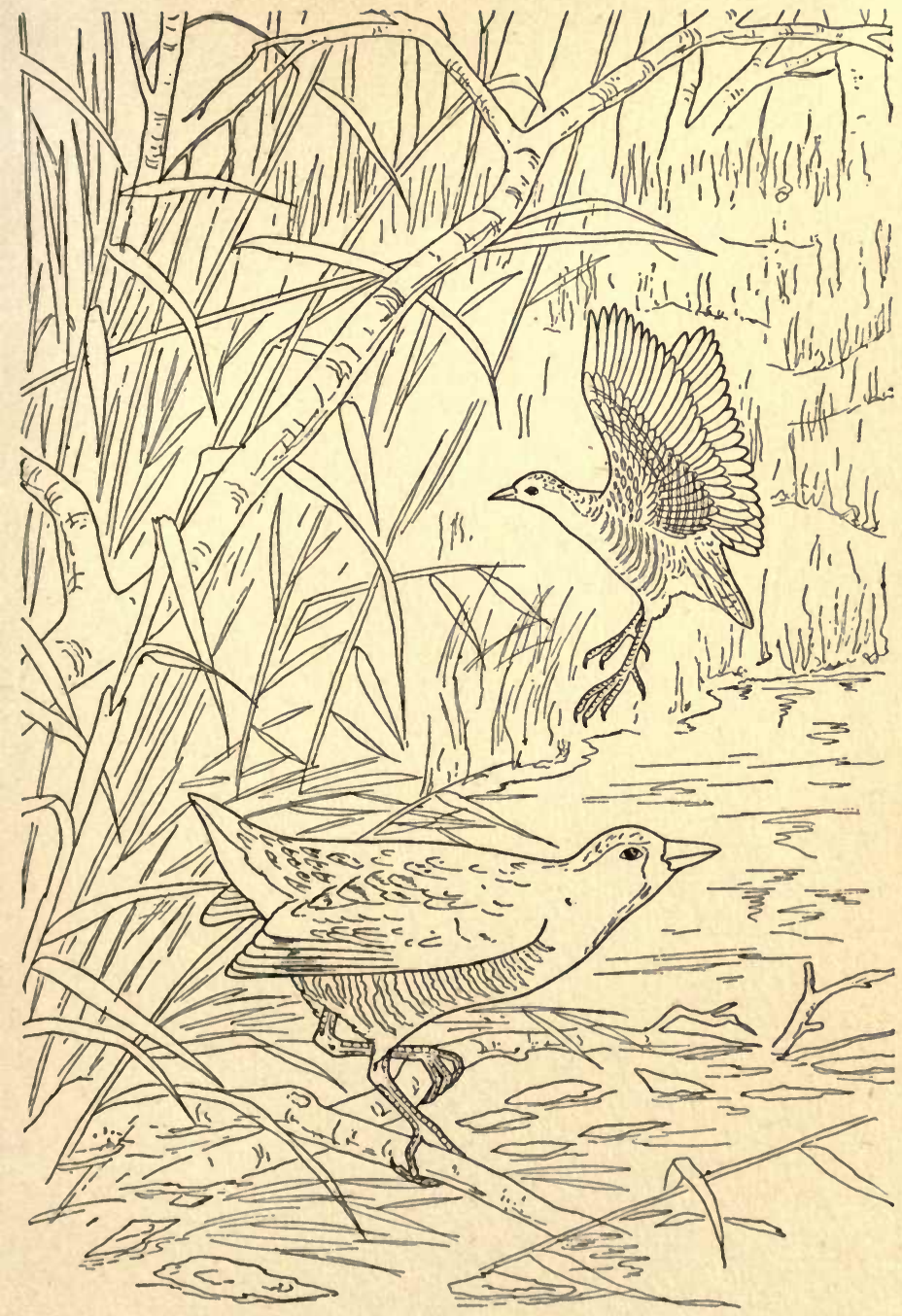

SORA 



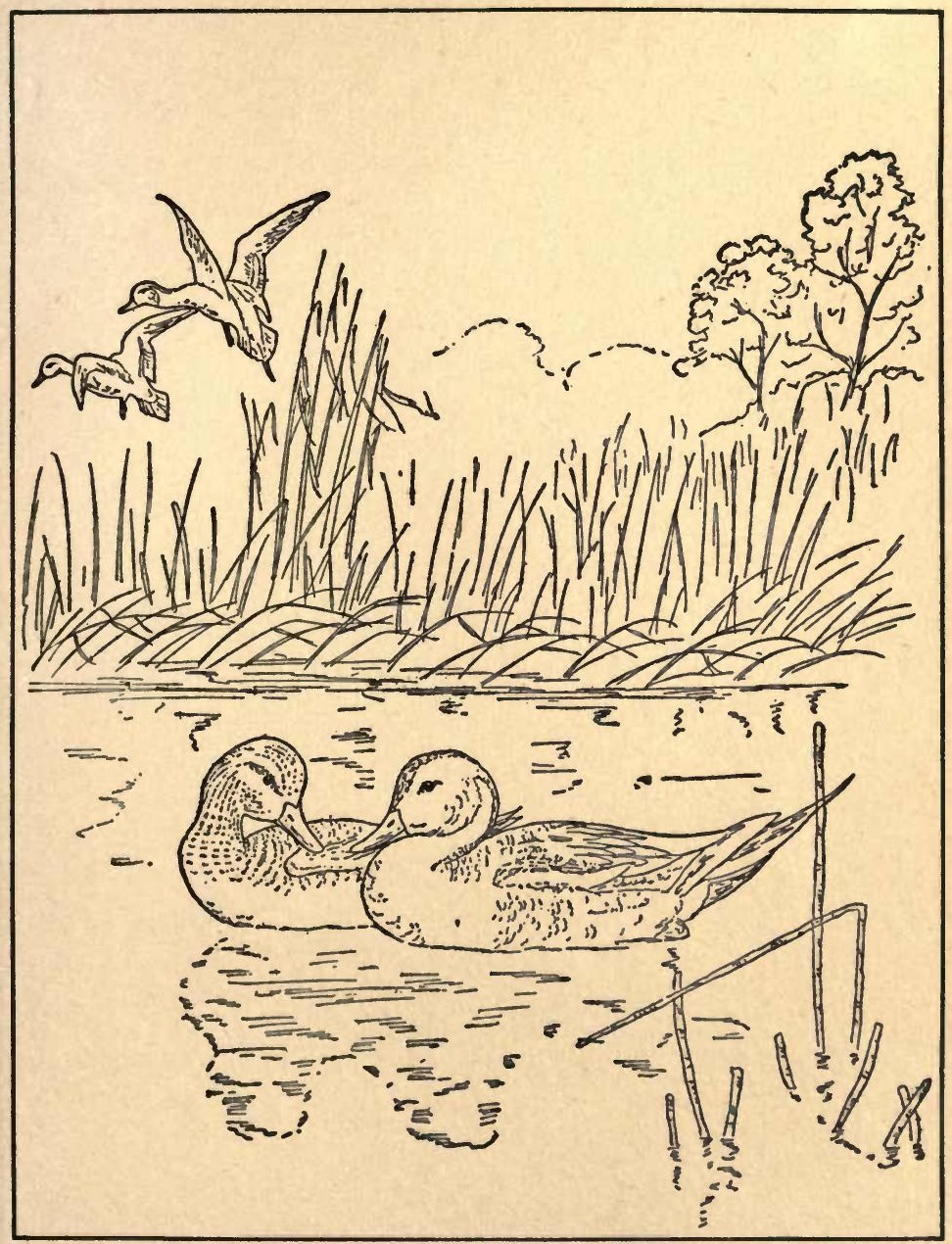

PINTAIL

$\begin{array}{ll}\text { Order-Anseris } & \text { Famfly-Anatides } \\ \text { Conus-DariLa } & \text { Spoclos-acuta }\end{array}$

Natlonal Assoclation of Audubon Societies 


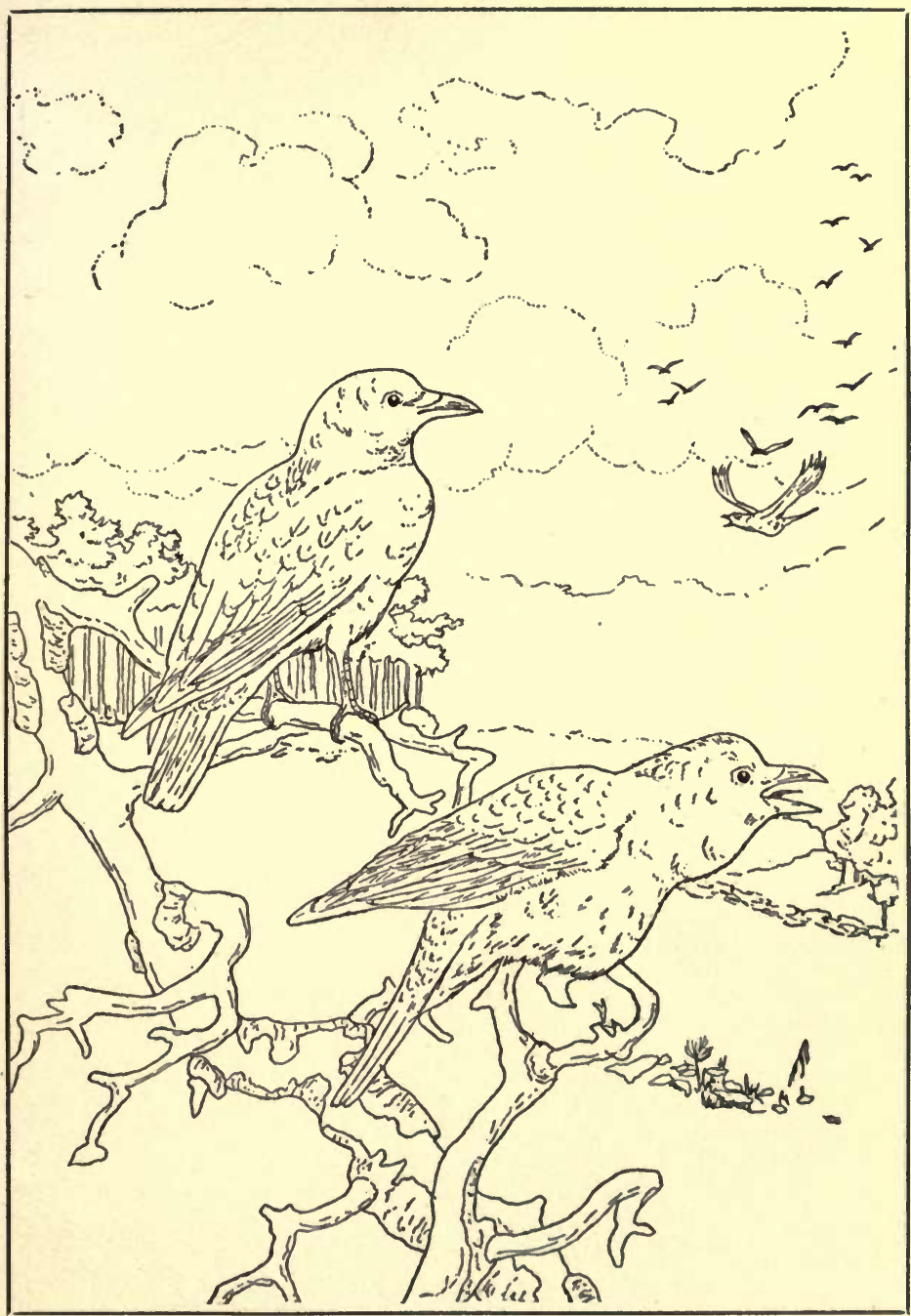

CROW

Order-Passeres

Genus-Corvus

Family-Coavide

Species-Brackrarrachos

National Association of Audubon Societies 


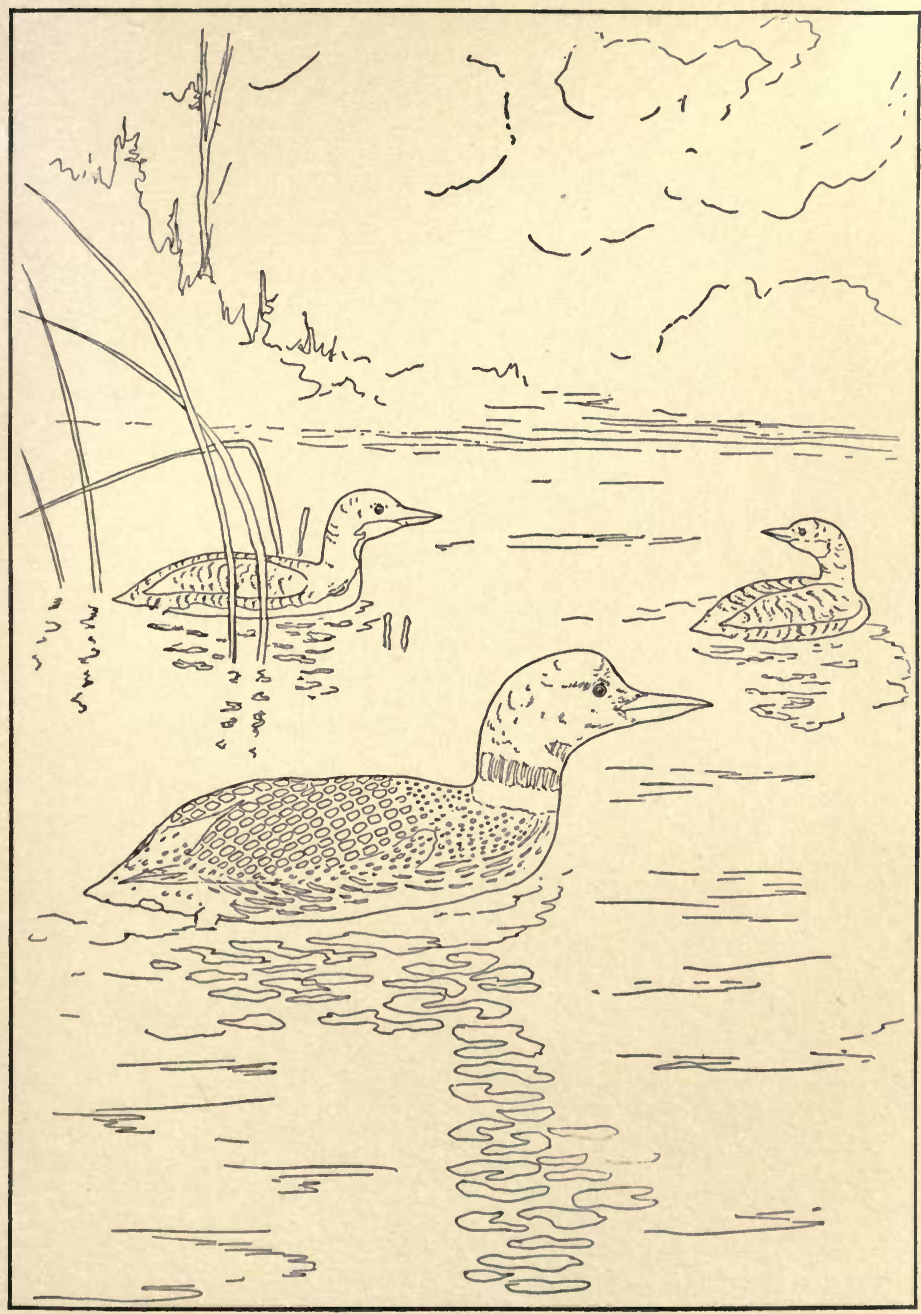

LOON

Order-Pygopodes

Genus-Gavia

Family-Gavinde

Species-I I MER

National Association of Audubon Societies 


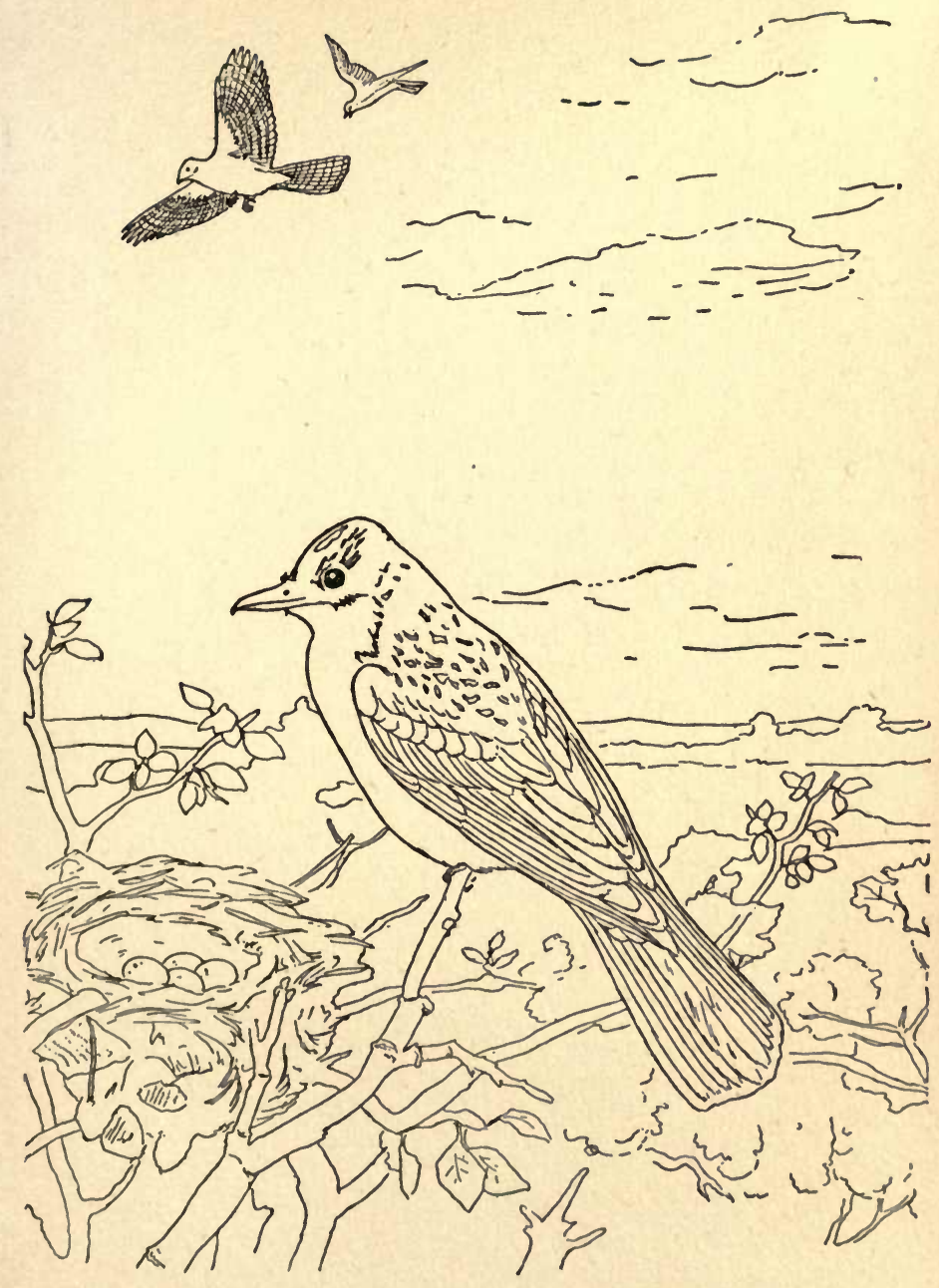

KINGBIRD

Order-PABBERES

Genus-Trrannug
Famlly-TrRanNide

Specles-TrRANNus

Natlonal Assoctation of Audubon Socletles 



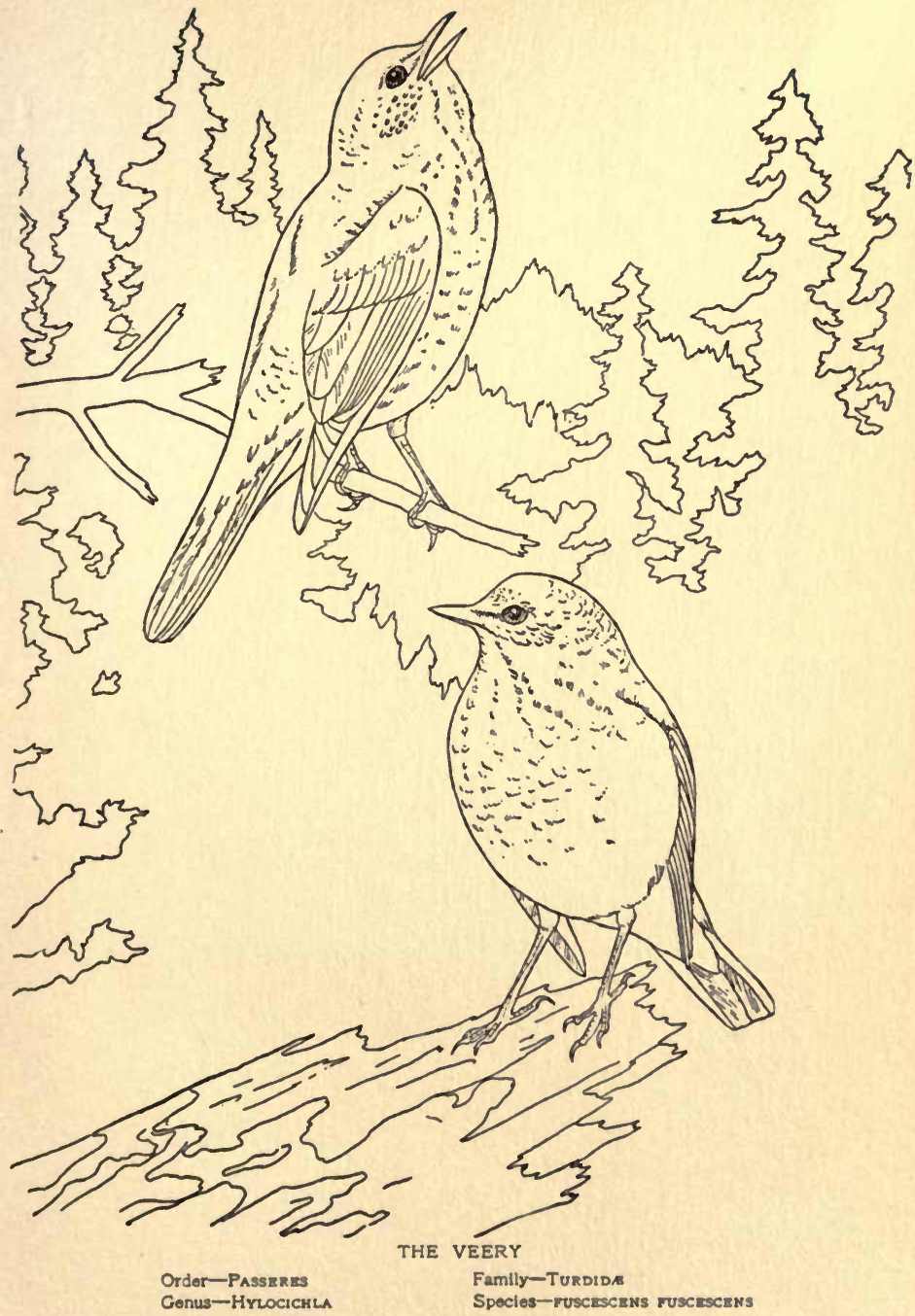

National Assoclation of Audubon Socleties 



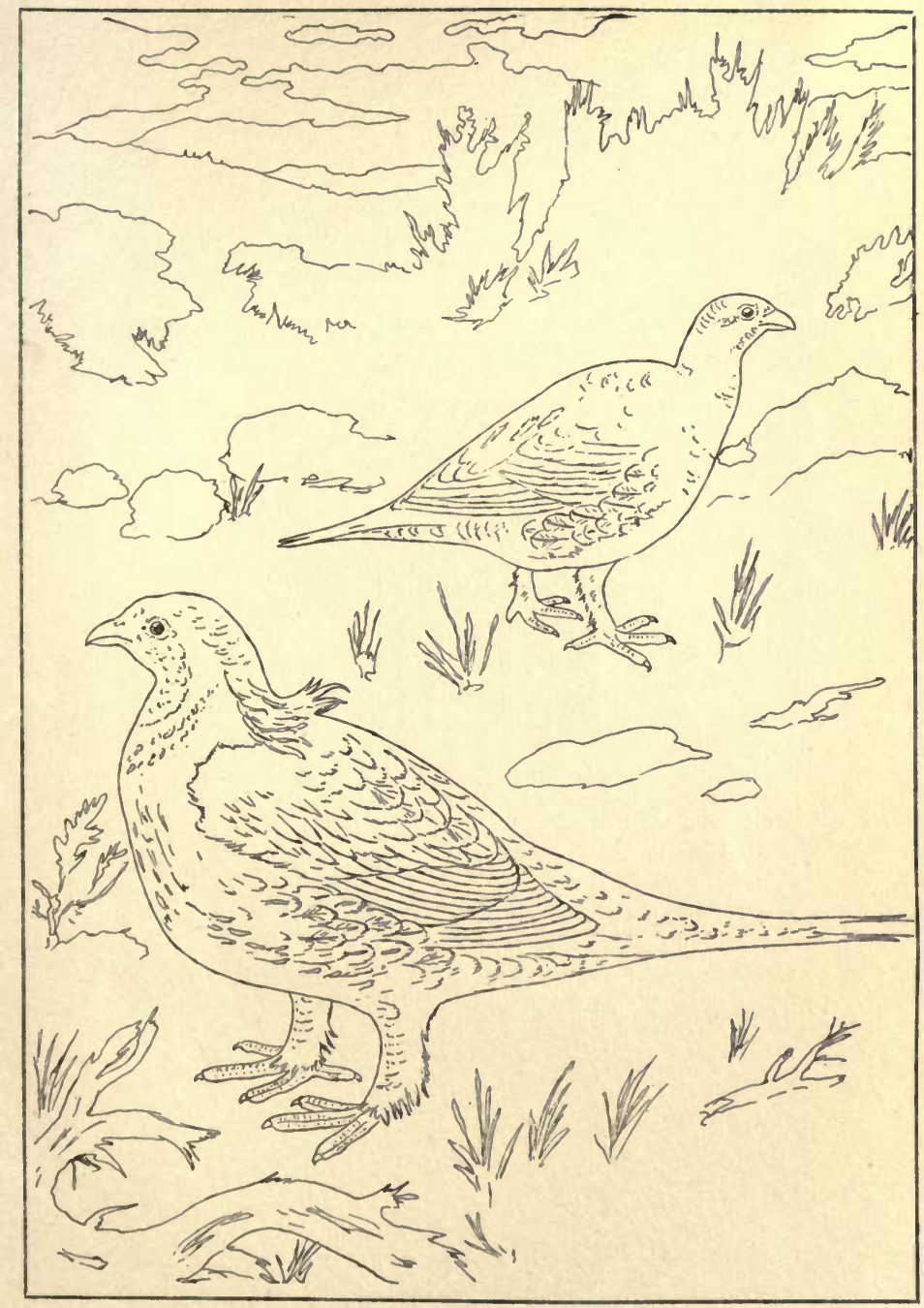

SAGE GROUSE

Order-Galline

Family-TzTRAONIDER

Genus-Centrocercus

Species-Urophasianus

National Association of Audubon Societies 

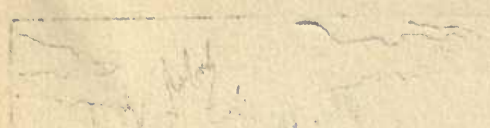

X.

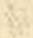




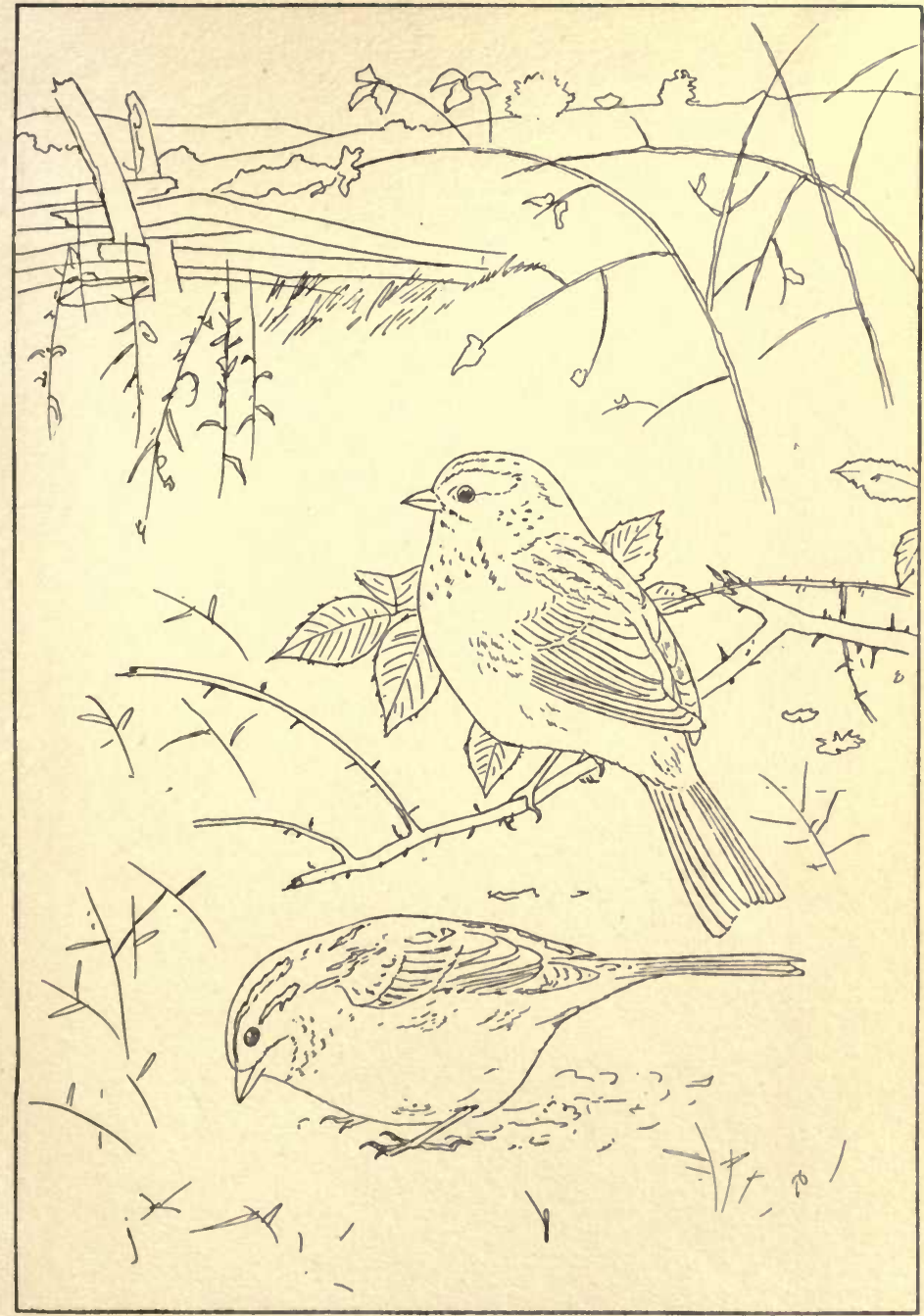

WHITE-THROATED SPARROW

Order-Passeres

Genus-Zonotrichia
Family-FringILLID

Species-albicollis 


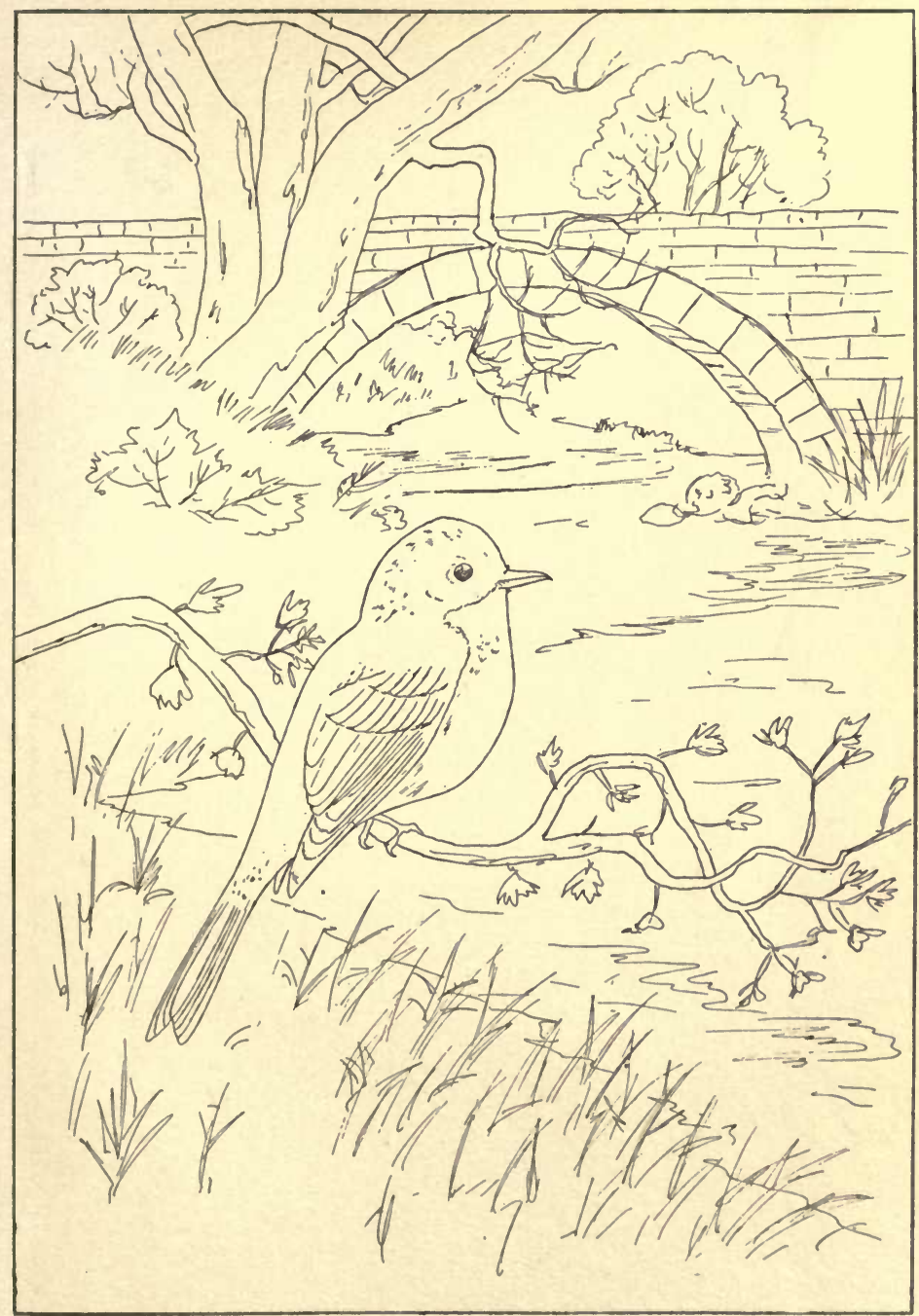

PHCEBE 


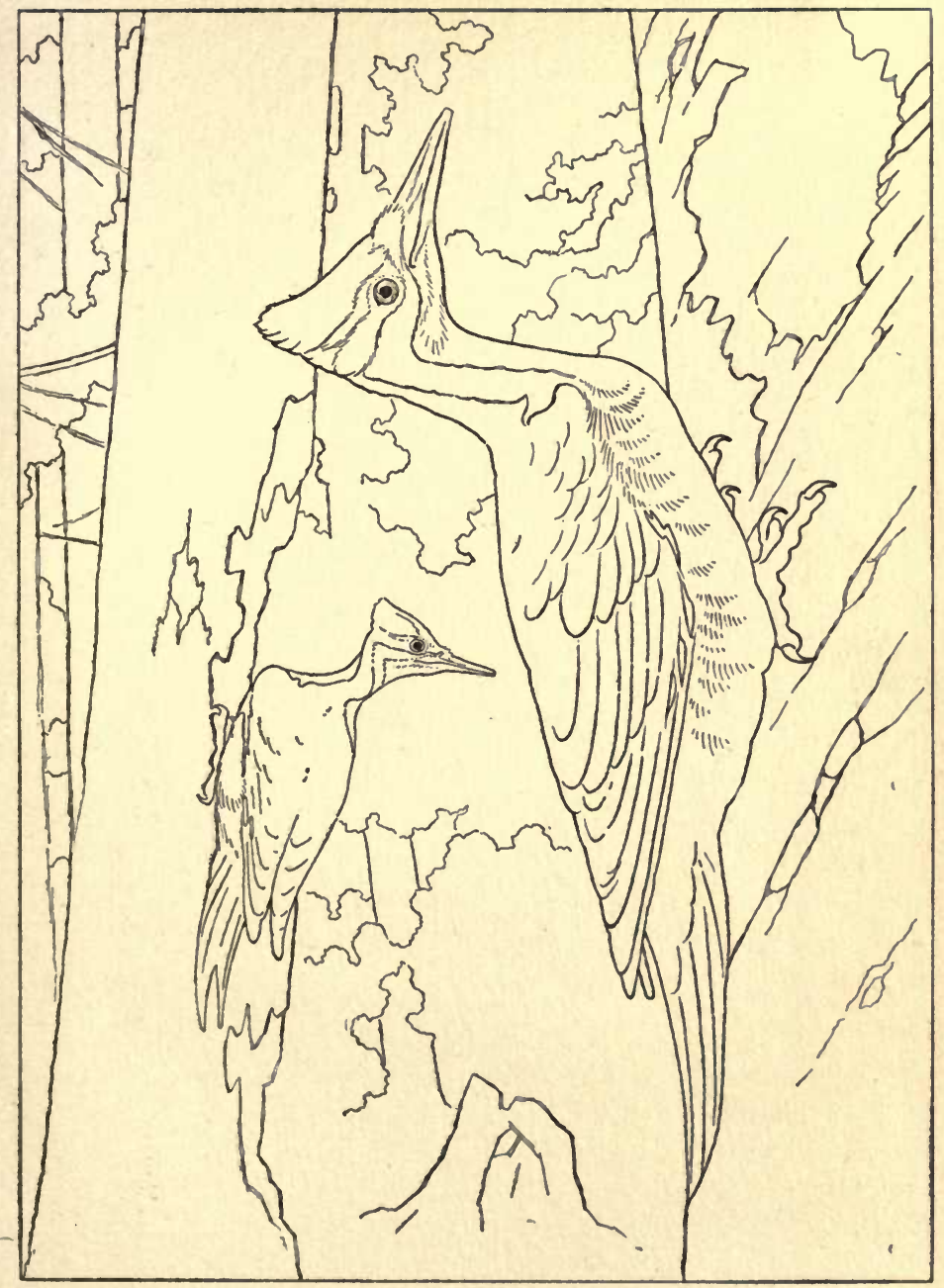

PILEATED WOODPECKER

Order-Pici

Genus-PhLaotomus
Family-Picide

Spocles-PILratus

National Association of Audubon Societies 


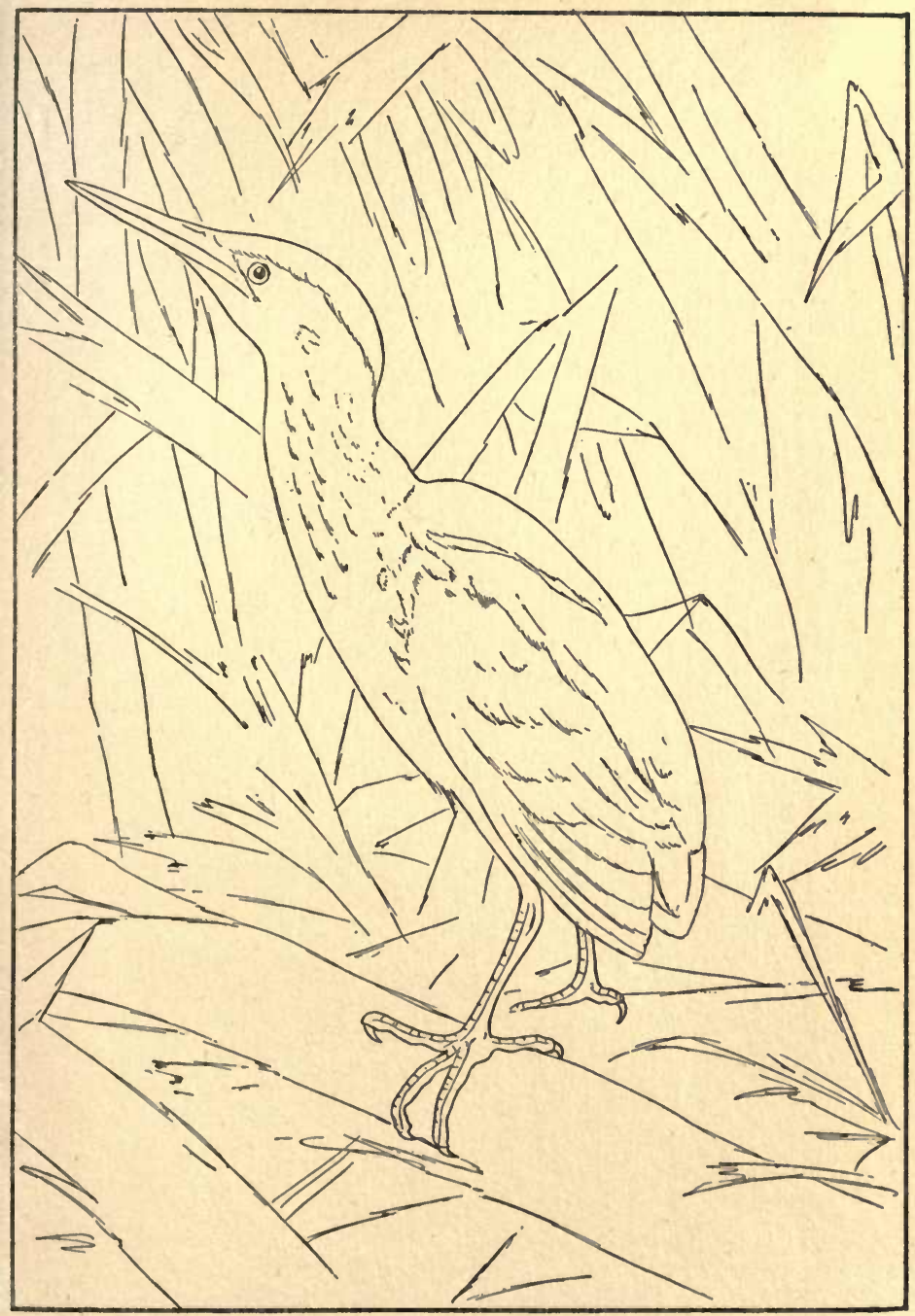

LEAST BITTERN

Order-HEROdIONEg

Genus-IXOBRYCHUs
Family-ARDEID

Species-Exilis 



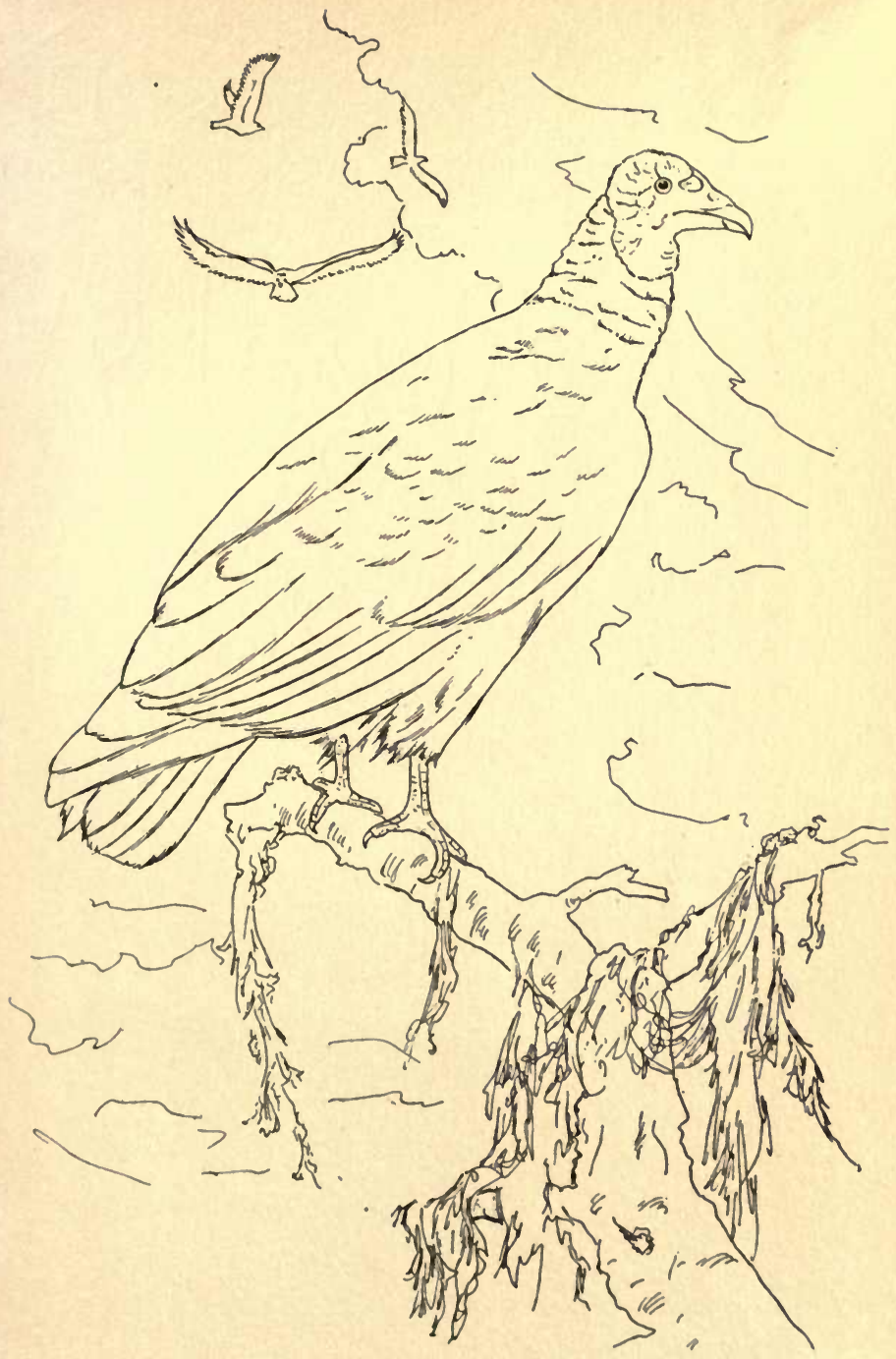

TURKEY VULTURE

Ordor-RATtoress

Genus-Cathirtes
Family-CathakTides

Spocios-AúrA SETTENTRIONÁLIS

National Assoclation of Audubon Socleties 


\section{INDEX}

\section{A}

Alaskan Longspur 265, 266, 267, 268

Arctic Tern, 385

Auklet, Crested , 257, 258, 259, 260

Least, 257

Avocet, 301, 349, 350, 351, 352

\section{B}

Bald Eagle, 325, 326, 327, 328

Baltimore Oriole, 221

Barn Swallow, 388

Bittern, 297, 301, 380

Least, 389, 390, 391, 392

Blackbird, Red-winged, 227, 389 Rusty, 227

Yellow-headed, 225, 226, 227, 228

Black-bellied Plover, 207

Black Brant, 254

Black-capped Chickadee, 241, 242, 243, $244,281,283,323$

Black-crowned Night Heron, 377

Black Duck, 304,333

Black-necked Stilt, 353, 354, 355, 356

Black Rail, 298, 299.

Black Shearwater, 351

Black Skimmer, 351

Black Tern, 228, 301, 388

Black Vulture, 398

Bluebird, 323, 380

Blue Jay, 283

Blue Shanks, 349

Blue-Winged Teal, $301,335$.

Boat-tailed Grackle, 262, 392

Bobolink, 204

Bob-White, 231, 252, 314, 362

Brant, Black, 254

Brewer's Sparrow, 361

Bridge Pewee, 370

Brown-headed Nuthatch, 236

Brown Thrasher, 269, 270, 271, 272

Brown Thrush, 269

Bullfinch, 357

Bullock's Oriole, 361

Buzzard, Turkey, 397, 398, 399, 400

\section{C}

Cackling Goose, 254, 255

California Quail, 229, 230, 231, 232, 259

Canvas-back, $301,302,303,334,336$

Canon Towhee, 316

Capercaillie, 361

Cardinal, 389

Carolina Wren, 389

Catbird, 277, 278, 279, 280, 287, 347

Chestnut-sided Warbler, 337, 338, 339, 340,369

Chickadee, Black-capped, 241, 242, 243, $244,281,282,283,323$

Chicken, Prairie, 363

Chipping, Sparrow, 317, 318, 319, 320, 369

Clapper Rail, 355

Chuck-Will's-widow, 290

Cock, Log, 376

Cock-of-the-woods, 376
Cock, Sage, 362,363

Coot, 325, 331, 332

Cowbird, 227, $315,339,340$

Crane, Sandhill, 299

Crested Auklet, 257, 258, 259, 260

Crow, 269, 305, 306, 307, 308, 347, 356, 374. 379

Fish, 263, 308, 356, 389, 392

Cuckoo, 380

Curlew, Eskimo, 245, 246

Hudsonian, 245, 246, 247, 248

Jack, 245

Long-billed, 245, 246

Short-billed, 245

\section{D}

Dove, Mourning, 361

Turtle, 379

Downy Woodpecker, 217, 218, 219, 220. 322

Duck, Black, 304, 333

Jew, 273

Lesser Scaup, 302

Ruddy, 301, 303

\section{E}

Eagle, Bald, 325, 326, 327, 328

Golden, 328

Eider, 330

Egret, 218, 295

Snowy, 213, 214, 215, 216

Emperor Goose, 253, 254, 255, 256

English Sparrow, 267, 348, 357, 358, 359. 360,381

Eskimo Curlew, 245, 246

\section{F}

Ferruginous Mockingbird, 269

Fish Crow, 263, 308, 356, 389, 392 Hawk, 326

Florida Wren, 373

Flicker, 376

Fycatcher, 372

Fox Sparrow, 368

Franklin's Gull, 228

\section{G}

Gadwall, 301, 303, 333

Gambel's Quail, 229

Gnatcatcher, 314

Godwit, Hudsonian, 301

Marbled, 301

Tell-tale, 350

Golden Eagle, 328

Golden Plover, 207

Good-God, 376

Goose, Cackling, 254, 255

Emperot, 253, 254, 255, 256

White-fronted, 254

Grackle, Boat-tailed, 262, 392

Grebe, Pied-billed, 326

Great White Heron, 213

Green Heron, 261, 262, 263, 264 


\section{Index}

Green-tailed Towhee, 316

Green-winged Teal, 301, 303

Grouse, Ruffed, 249, 250, 251, 252, 369

Sage, 361, 362, 363, 364

Sharp-tailed, 364

Snow, 237

Guillemot Pigeon, 275

Gull, Franklin's, 228

\section{$\mathbf{H}$}

Hairy Woodpecker, 220

Hawk, Fish, 326

Sharp-shinned, 367

Sparrow, 367,376

Hen, Sage, 364

Heron, Black-crowned Night, 377 Great White, 213

Green, 261, 262, 263, 264

Little Blue, 213, 214

Louisiana, 214, 215, 295

Horned Lark, 209, 210, 211, 212

Western, 361

Horned Puffin, 276

House Wren, 219

Hudsonian Curlew, 245, 246, 247, 248

Hudsonian Godwit, 301

Hummingbird, Ruby-throated, 221, 222, 223,224

\section{I}

Ibis, 399

Ibis, White, 295

Ivory-billed Woodpecker, 374

\section{$J$}

Jack Curlew, 245

Jay, Blue, 283

Jew Duck, 273

Junco, Montana, 384

Slate-colored, $381,382,383,384$

K.

Killdeer, 204

Kingbird, 321, 322, 323, 324

\section{L}

Lapland Longspur, 265

Lark, Horned, 209, 210, 211, 212

Prairie Horned, 211

Western Horned, 361

Least Auklet, 257

Least Bittern, 389, 390, 391, 392

Least Sandpiper, 205, 206, 207, 208

Least Tern, 385, 386, 387, 388

Lesser Scaup Duck, 302

Lesser Yellowlegs, 301

Linnet, 357

Little Blue Heron, 213, 214

Log-cock, 376

Long-billed Curlew, 245, 246

Longspur, Alaskan, 265, 266, 267, 268

Lapland, 265

Loon, s01, 309, 310, 311, 312

Louisiana Heron, 214, 215, 295

\section{M}

Mallard, 301, 303, 304, 333, 335, 336

Man-o'-war-bird, 214

Marbled Godwit, 301

Meadowlark, 204, 314

Western. 361

Mockingbird, 277

Ferruginous, 269
Montana Junco, 384

Mourning Dove, 361

Mud-hen, 297

N

Nightingale, 282, 314

Nonpareil, 314

Northern Phalarope, 301

Northern Raven, 380

Nuthatch, Brown-headed, 236

Pigmy, 236

Red-breasted, 235, 236

White-breasted, 233, 234, 235, 236

O

Olive-backed Thrush, 346

Oriole, Baltimore, 221

Bullock's, 361

Oregon Towhee, 316

Osprey, 326, 327, 328

Owl, Screech, 367

Western Horned, 361

P

Painted Redstart, 344

Parrot, Sea, 273

Partridge, 249, 383

Peafowl, 363

Pewee, 372

Bridge, 370

Phalarope, Northern, 301

Phoebe, $369,370,371,372$

Pied-billed Grebe, 326

Pigeon, 224

Pigeon Guillemot, 275

Pigmy Nuthatch, 236

Pileated Woodpecker, 373, 374, 375, 376 Northern, 376

Pintail, 301, 302, 303, 304, 333, 335

Pipit, 211

Plover, Black-bellied, 207 Golden, 207

Upland, 204

Prairie Chicken, 363

Prairie Horned Lark, 211

Ptarmigan, Rock, 237

White-tailed, 237

Willow, 237, 238, 239, 240

Puffin, Horned, 276

Tufted, 273, 274, 275, 276

Q

Quail, 229, 230, 231, 232

California, 229, 230, 231, 232, 259

Gambel's, 229

Sea, 259

Valley, 229

\section{$\mathbf{R}$}

Rail, Black, 298, 299

Clapper, 355

Yellow, 297

Virginia, 299

Raven, 377, 378, 379, 380

Northern, 380

Red-bellied Woodpecker, 283

Red-breasted Nuthatch, 235, 236

Red-breasted Snipe, 351

Red-eyed Vireo, 322, 393, 394, 395, 396

Red-headed Woodpecker, 220, 328

Redhead, 301, 303, 336

Redstart, 341, 343, 344, 369

Painted, 344

Red-winged Blackbird, 227, 389

Red-winged Starling, 356 


\section{Index}

Robin, 269, 348, 388, 393

Wood, 285

Rock Ptarmigan, 237

Roseate Spoonbill, 293, 294, 295, 296, 351

Ruby-throated Hummingbird, 221, 222, 223,224

Ruddy Duck, 301,303

Ruffed Grouse, 249, 250, 251, 252

Rusty Blackbird, 227

$\mathbf{S}$

Sage Cock, 362,363

Sage Grouse, $361,362,363,364$

Sage Hen, 364

Sage Thrasher, 361

Sandhill Crane, 299

Sandpiper, Least, 205, 206, 207, 208

Semipalmated, 205, 206, 207, 208

Solitary, 202

Spotted, 201, 202, 203, 204, 321

Sapsucker, 218, 281

Semipalmated Sandpiper, 205, 206, 207, 208

Scarlet Tanager, 278

Screech Owl, 367

Scoter, Surf, 329, 330, 331, 332

Sea Parrot, 273

Sea Quail, 259

Shanks, Blue, 349

Sharp-shinned Hawk, 367

Sharp-tailed Grouse, 364

Shearwater, Black, 351

Short-billed Curlew, 245

Shoveller, 301, 333, 334, 335, 336

Skimmer, Black, 351

Skylark, 357

Slate-colored Junco, 381, 382, 383, 384

Snipe, Red-breasted, 351

Snowbird, 381, 383, 384

Snowy Egret. 213, 214, 215, 216

Snow Grouse, 237

Solitary Sandpiper, 202

Solitary Vireo, 297

Song Sparrow, 365

Sora, 297, 298, 299, 300

Sparrow, Brewer's, 361

Chipping, 317, 318, 319, 320, 368

English, 267, 348, 357, 358, 359, 360, 381

Fox, 368

Song, 365

Tree, 381

Vesper Sparrow, 211

White-throated, $365,366,367,368,381$

Sparrow Hawk, 367, 376

Spoonbill, Roseate, 293, 294, 295, 296, 351

Spotted Sandpiper, 201, 202, 203, 204, 321

Starling, Red-winged, 356

Stilt, Black-necked, 353, 354, 355, 356

Surf Scoter, 329, 330, 331, 332

Swallow, Barn, 388

\section{$\mathbf{T}$}

Tanager, Scarlet, 278

Tawny Thrush, 345

Teal, Blue-winged, 301, 335

Green-winged, 301, 303

Tell-tale Godwit, 350

Tern, Arctic, 385

Black, 228, 301, 388

Least, $385,386,387,388$

Thrasher, Brown, 269,270, 271, 272

Sage, 361

Thrush, Brown, 269

Olive-backed, 346

Tawny, 345

Wilson's, 345

Wood, 270, 278, 285, 286, 287, 288, 342 .

345
Tup-up, 202

Titlark, 211

Titmouse, Tufted, 218, 281, 282, 283, 284

Towhee, 313, 314, 315, 316

Canon, 316

Green-tailed, 316

Oregon, 316

White-eyed, 316

Tree Sparrow, 381

Tufted Puffin, 273, 274, 275, 276

Tufted Titmouse, 218, 281, 282, 283, 284

Turkey Buzzard, 397, 399

Turkey Vulture, 295, 322, 397, 398, 399, 400

Wild, 383

Turtle Dove, 379

\section{U}

Upland Plover, 204

\section{V}

Valley Quail, 229

Veery, 270, 314, 322, 345, 346, 347, 348, 370

Vesper Sparrow, 211

Vireo, Red-eyed, 322, 393, 394, 395, 396 Solitary, 297

Virginia Rail, 299

Vulture, Black, 398

Turkey, 295, 322, 397, 398, 399, 400

W

Warbler, Chestnut-sided, 337, 338, 339, 340, 369

Yellow, 339

Western Meadowlark, 361

Western Horned Owl, 361

Whip-poor-will, 289, 290, 291, 292, 297

White-breasted Nuthatch, 233, 234, 235, 236

White-fronted Goose, 254

White Ibis, 295

White-tailed Ptarmigan, 237

White-eyed Towhee, 316

White-throat, $365,366,367$

White-throated Sparrow, 365, 366, 367 . 368,381

Widgeon, 301, 303, 333

Wild Turkey, 283

Willow Ptarmigan, 237, 238, 239, 240

Winter Wren, 314

Wilson's Thrush, 345

Woodpecker, Downy, 217, 218, 219, 220, 322

Hairy, 220

Ivory-billed, 374

Pileated, 373, 374, 375, 376

Red-bellied, 283

Red-headed, 220, 328

Wood Robin, 285 , :

Wood Thrush, 270, 278, 285, 286, 287, 288, 342,345

Wren, Carolina, 389

Florida, 373

House, 219

Winter, 314

\section{$\mathbf{Y}$}

Yellow-headed Blackbird, 225, 226, 227 , 228

Yellowlegs, Lesser, 301

Yellow Rail, 297

Yellow Warbler, 339 


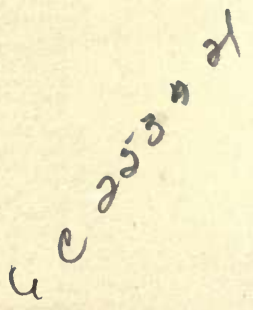



<smiles>C[TlH]</smiles> 

<smiles>C1CC1</smiles> 

<smiles>C1CC1</smiles> 


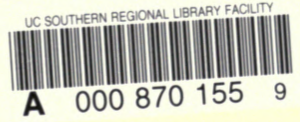


